\title{
Sujeitos da história do ensino de leitura e escrita no Brasil
}

\author{
Maria do Rosário L. Mortatti \\ Estela N. M. Bertoletti \\ Fernando R. de Oliveira \\ Márcia C. de Oliveira Mello \\ Thabatha A. Trevisan
}

(Orgs.)

MORTATTI, MRL., et al., orgs. Sujeitos da história do ensino de leitura e escrita no Brasil [online]. São Paulo: Editora UNESP, 2015, 302 p. ISBN 978-85-68334-36-2. Available from SciELO Books $<\underline{\text { http://books.scielo.org }>\text {. }}$

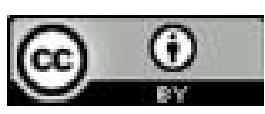

All the contents of this work, except where otherwise noted, is licensed under a Creative Commons Attribution 4.0 International license.

Todo o conteúdo deste trabalho, exceto quando houver ressalva, é publicado sob a licença Creative Commons Atribição 4.0.

Todo el contenido de esta obra, excepto donde se indique lo contrario, está bajo licencia de la licencia Creative Commons $\underline{\text { Reconocimento } 4.0 .}$. 


\section{Sujeitos DA História do Ensino DE LeITURA E Escrita NO BRASIL}




\title{
FUNDAÇÃO EDITORA DA UNESP
}

\author{
Presidente do Conselho Curador \\ Mário Sérgio Vasconcelos \\ Diretor-Presidente \\ José Castilho Marques Neto \\ Editor-Executivo \\ Jézio Hernani Bomfim Gutierre
}

Superintendente Administrativo e Financeiro

William de Souza Agostinho

Assessores Editoriais

João Luís Ceccantini

Maria Candida Soares Del Masso

Conselho Editorial Acadêmico

Áureo Busetto

Carlos Magno Castelo Branco Fortaleza

Elisabete Maniglia

Henrique Nunes de Oliveira

João Francisco Galera Monico

José Leonardo do Nascimento

Lourenço Chacon Jurado Filho

Maria de Lourdes Ortiz Gandini Baldan

Paula da Cruz Landim

Rogério Rosenfeld

Editores-Assistentes

Anderson Nobara

Jorge Pereira Filho

Leandro Rodrigues 


\section{MARIA DO ROSÁRIO L. MORTATTI ESTELA N. M. BERTOLETTI FERNANDO R. DE OLIVEIRA MÁRCIA C. DE OLIVEIRA MELLO THABATHA A. TREVISAN (Orgs.)}

\section{Sujeitos DA \\ História do ENSINO \\ DE LeITURA E Escrita \\ NO BRASIL}


Direitos de publicação reservados à:

Fundação Editora da Unesp (FEU)

Praça da Sé, 108

01001-900 - São Paulo - SP

Tel.: (0xx11) 3242-7171

Fax: (0xx11) 3242-7172

www.editoraunesp.com.br

www.livrariaunesp.com.br

feu@editora.unesp.br

CIP - BRASIL. Catalogação na publicação

Sindicato Nacional dos Editores de Livros, RJ

S946

Sujeitos da história do ensino de leitura e escrita no Brasil / Organização Maria do R. Longo Mortatti et al. São Paulo: Editora IUnesp Digital, 2014.

Recurso digital

Formato: ePDF

Requisitos do sistema: Adobe Acrobat Reader

Modo de acesso: World Wide Web

ISBN 978-85-68334-36-2 (recurso eletrônico)

1. Alfabetização. 2. Escrita. 3. Leitura. 4. Educação - Brasil. 5. Livros eletrônicos. I. Mortatti, Maria do R. Longo.

$15-20472$

CDD: 370.981

CDU: $37(81)$

Este livro é publicado pelo projeto Edição de Textos de Docentes e Pós-Graduados da UNESP - Pró-Reitoria de Pós-Graduação da UNESP (PROPG) / Fundação Editora da Unesp (FEU)

Editora afiliada:

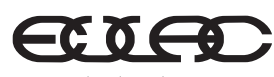

Asociación de Editoriales Universitarias de América Latina y el Caribe

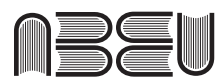

Associação Brasileira de Editoras Universitárias 


\section{SUMÁRIO}

Prefácio 7

Rosa Fátima de Souza

Apresentação 11

Maria do Rosário Longo Mortatti

1 Cartilha da infancia, de Thomaz Galhardo (1855-1904) 23

Luana Grazielle dos Santos

2 Antonio da Silva Jardim (1860-1891) na história do ensino de leitura e escrita no Brasil 35

Franciele Ruiz Pasquim

3 João Köpke (1852-1926) na história do ensino de leitura e escrita no Brasil 59

Maria do Rosário Longo Mortatti

4 Ramon Roca Dordal (1854-1938) e Carlos Alberto Gomes Cardim (1875-1938) na história da alfabetização no Brasil 77

Franciele Ruiz Pasquim

5 Arnaldo de Oliveira Barreto (1869-1925): atuação e produção para o ensino da leitura 93

Vanessa Cuba Bernardes 
6 A atuação profissional e a produção escrita de Francisco Vianna (1876-1935) na história do ensino da leitura 103 Angélica Pall Oriani

7 O pioneirismo de Theodoro de Moraes (1877-1956) na história do ensino da leitura no Brasil 117 Bárbara Cortella Pereira

8 Aspectos da vida, da atuação profissional e da bibliografia de e sobre Antonio Firmino de Proença (1880-1946) 135

Monalisa Renata Gazoli

9 Renato Fleury (1895-1980) e o ensino da leitura nas escolas rurais paulistas 153

Cyntia Grizzo Messenberg

10 Lourenço Filho (1897-1970), escritor de e sobre literatura infantil e juvenil 169

Estela Natalina Mantovani Bertoletti

11 O educador paulista Antônio D’Ávila (1903-1989): sua atuação e sua produção escrita 195

Thabatha Aline Trevisan

12 Bárbara V. de Carvalho (1915-2008) na história do ensino da literatura infantil 221

Fernando Rodrigues de Oliveira

13 Emilia Ferreiro (1935-) e a psicogênese da língua escrita 245

Márcia Cristina de Oliveira Mello

14 João Wanderley Geraldi (1946-) e o texto na sala de aula 277

Luzia de Fátima Paula

Sobre os autores 299 


\section{Prefácio}

A leitura do presente livro me fez recordar uma conhecida citação de John Locke: "Embora o uso familiar das coisas à nossa volta destrua nossa surpresa, isso não cura nossa ignorância". A advertência é clara: para conhecer a realidade que nos cerca, seja ela de natureza física ou social, é preciso desconfiar daquilo que nos rodeia, do que nos parece banal, comum, por demais familiar e ordinário. Ler e escrever são exemplos desses gestos e habilidades correntes, que costumam ser naturalizados, ainda mais na atualidade, em que a maioria das crianças passa pela escola, instituição universalmente destinada ao ensino desses saberes elementares. Muitos, no entanto, se esquecem de como foi - e ainda é - difícil aprender a ler e a escrever, isto é, apropriar-se desses códigos da cultura moderna. Há mais de dois séculos, ensinar a ler e escrever continua no centro das proposições pedagógicas e das políticas em defesa da universalização da educação pública. O ensino da leitura e da escrita - consideradas habilidades indispensáveis no processo educacional - tornou-se uma das principais atividades educativas levadas a termo na escolarização inicial de crianças, um desafio diuturno de gerações de alunos e professores. Por isso, interrogar sobre o passado desse ensino no Brasil, tema central deste livro, não é uma questão menor. Ao contrário, ela está no cerne do debate sempre 
atual e imprescindível acerca das finalidades culturais da escola e da educação como direito social de cidadania. Nesse sentido, entre as várias contribuições relevantes deste livro, vale a pena realçar a importância da temática para a compreensão da cultura escolar e o lugar que esta publicação vem a ocupar no espaço da produção na área da Alfabetização e da História da Educação no Brasil.

Abrangendo o período de mais de um século, da década de 1870 à atualidade, os diversos estudos que compõem este livro põem em destaque cartilhas, livros de leitura, manuais, textos, artigos publicados em jornais e periódicos, polêmicas em torno dos métodos de ensino e a atuação de quem produziu e problematizou sobre o ensino de leitura e escrita. Os estudos evidenciam tanto os interesses econômicos e comerciais subjacentes à produção de materiais para esse ensino quanto as tensões políticas que envolveram as disputas dos educadores ao longo do tempo. Dessa maneira, o leitor pode se aproximar das tematizações, concretizações e normatizações que estiveram implicadas no debate político e pedagógico que envolveu a questão da alfabetização no país. Assim, cabe também ressaltar a constituição da temática como objeto de pesquisa e sua originalidade inquestionável. Pesquisadores da área da Educação sabem a dificuldade em que consiste a elaboração de uma problemática de investigação relevante e a consolidação de um grupo de pesquisa que, de forma articulada, sistemática e orgânica, se dedique por vários anos (no caso deste livro, duas décadas) ao aprofundamento de um mesmo tema. Este livro é o resultado da produção consolidada do Grupo de Pesquisa "História o Ensino da Língua e Literatura no Brasil” (GPHELLB), coordenado pela professora Maria do Rosário Longo Mortatti e vinculado ao Programa de Pós-Graduação em Educação da Unesp de Marília, e mostra a potencialidade do investimento em uma proposta articulada de pesquisa. $\mathrm{O}$ encadeamento orgânico dos estudos compreendidos neste livro não decorre apenas da temática, cujo ineditismo é inegável. O grupo de pesquisa compartilha também um método de investigação experienciado e continuamente posto a prova pelas investigações realizadas em nível de doutorado, mestrado, pós-doutorado e iniciação científica. 
Tal método envolve o enraizamento na exploração das fontes empíricas, uma perspectiva teórica de análise do discurso - a configuração textual -, e procedimentos de pesquisa histórica caracterizados pelo rigor e pelo aprofundamento compreendendo a localização, recuperação, reunião, seleção e ordenação de fontes documentais e a elaboração de instrumentos de pesquisa/guias de fontes. Ressalta-se, ainda, o diálogo interdisciplinar entre Educação, Letras, Linguística e História. Esse modo de produção do conhecimento sobre a temática perpassa cada um dos textos reunidos no livro. É interessante salientar, ainda, a preocupação do grupo em constituir um acervo documental e bibliográfico e em disponibilizar instrumentos de pesquisa. O que à primeira vista pode parecer um produto residual de uma trajetória de pesquisa é constitutivo dos procedimentos de investigação adotados pelos pesquisadores, o que tem possibilitado o acúmulo significativo de referências bibliográficas sobre o tema e sobre a produção de e sobre os sujeitos educacionais investigados. Certo é que a produção de instrumentos de pesquisa é paradigmática na área da Educação, pois a elaboração de guias de fontes e bibliografias analíticas, entre outros tipos de obras de referência, como tem acertadamente reafirmado Célia Reis Camargo, permite acelerar o processo de pesquisa por meio da democratização de informações especializadas que auxiliam outros pesquisadores e fertilizam novas investigações.

Consubstanciando importantes dimensões temáticas, teóricometodológicas, informações e interpretações valiosas, Sujeitos da história do ensino de leitura e escrita no Brasil constitui, por certo, obra de referência na História da Educação. De modo especial, vale mencionar a importância dos sujeitos educacionais retratados neste livro. Antônio da Silva Jardim, Thomaz Galhardo, João Köpke, Ramom Roca Dordal, Carlos Alberto Gomes Cardim, Arnaldo de Oliveira Barreto, Theodoro de Moraes, Antonio Firmino de Proença, Renato Sêneca Fleury, Manoel Bergstrom Lourenço Filho, Antonio D’Ávila, Barbara Vasconcelos de Carvalho, Emília Ferreiro e João Wanderley Geraldi são nomes conhecidos na história da educação brasileira. Ao analisarem a produção desses autores e as 
referências bibliográficas sobre eles, os artigos deste livro descortinam aspectos originais da história do pensamento educacional e social do Brasil. Mais do que isso, os textos nos convidam a uma imersão na história dos intelectuais considerando a singularidade desses homens e mulheres, desses educadores que pensaram não apenas o ensino da leitura e da escrita, mas os problemas políticos da educação e da formação do cidadão na sociedade brasileira. Se, como nos ensina Jacques Le Goff, o intelectual, em seu sentido amplo, desde a Idade Média, designa aquele cujo ofício é pensar e ensinar seu pensamento, aliando reflexão pessoal e sua difusão pelo ensino ou pelo ofício da escrita, os sujeitos educacionais investigados neste livro atestam a atuação profissional marcada pela indissociabilidade entre a docência, a reflexão crítica, o posicionamento político e a exposição pública de ideias e concepções. Portanto, este livro merece uma leitura atenta por parte de todos os que se interessam pelo passado e presente dos desafios de ensinar a ler e escrever, discussão primordial no campo da educação e da cultura.

Araraquara/SP, agosto de 2014.

Rosa Fátima de Souza 


\section{Apresentação}

Esta é uma obra coletiva organizada pela coordenadora e por integrantes do Grupo de Pesquisa "História do Ensino de Língua e Literatura no Brasil” (GPHELLB), em comemoração aos vinte anos de seu funcionamento.

O grupo foi criado em 1994, com sede na Unesp, campus de Presidente Prudente. Desde 1998, está sediado no campus de Marília e, desde 2014, conta com a participação da professora Rosa Fátima de Souza Chaloba, como vice-líder. ${ }^{1}$ Além de pesquisadores de outras instituições, integram ou integraram o GPHELLB todos os meus orientandos: de mestrado e doutorado em Educação (campus de Marília) e em Letras (campus de Assis); de curso de especialização; de cursos de graduação em Pedagogia, Biblioteconomia e Relações Internacionais (campus de Marília); e, mais recentemente, supervisandos de pós-doutorado.

O GPHELLB conta com acervo documental e bibliográfico atualmente com mais de dois mil itens referenciados, entre os quais se encontram: 84 cartilhas de alfabetização; 60 livros de leitura/ séries graduadas para o ensino primário; 256 livros didáticos de Língua Portuguesa para o ensino primário e secundário e gramá-

1 De 2009 a 2010, a vice-líder foi a professora Rosane M. de Castro. 
ticas escolares; 55 manuais de ensino para cursos de formação de professores; 437 livros de literatura infantil e juvenil; e 347 documentos oficiais sobre educação e ensino. $\mathrm{O}$ acervo documental tem servido de base para as pesquisas desenvolvidas pelos integrantes do grupo e por outros pesquisadores.

As atividades do GPHELLB articulam-se ao Programa de Pesquisa "História do Ensino de Língua e Literatura no Brasil" (PPHELLB), dos quais resultou o Projeto Integrado de Pesquisa "História do Ensino de Língua e Literatura no Brasil" (PIPHELLB), que vem sendo desenvolvido, em etapas trienais, desde 1995.

Com temática então inédita e criado em um momento em que as pesquisas históricas em educação já conquistavam o devido prestígio acadêmico-científico, o GPHELLB assumiu como principal desafio a necessidade de definição de objetos de estudo, de fontes documentais, de vertentes teóricas e de abordagens metodológicas, em consonância com as necessidades históricas apontadas por estudos de pesquisadores brasileiros e estrangeiros, com a característica interdisciplinar da temática do grupo e com a busca de diálogo com áreas/campos de conhecimentos correlatos, especialmente Educação, Letras, Linguística, História.

O GPHELLB, o PPHELLB e o PIPHELLB estão organizados em torno de temática, objetivo geral e método de investigação que são comuns a todas as pesquisas de seus integrantes.

A temática - ensino de língua e literatura no Brasil - subdivide-se, atualmente, em seis núcleos temáticos/linhas de pesquisa: história da alfabetização; história do ensino de língua portuguesa; história do ensino de literatura; história da literatura infantil; história da formação de professores; memória e história da educação.

Dada a característica interdisciplinar da temática, nem sempre, porém, é possível delimitar a vinculação dos trabalhos a uma única linha. Assim, embora os trabalhos dos integrantes do grupo tenham foco e objetivos específicos, podem estar vinculados a mais de uma dessas linhas, ou dialogam com outras. 
Quanto aos objetivos gerais do GPHELLB, foram assim definidos: contribuir para a produção de uma história do ensino de língua e literatura no Brasil; contribuir para o alargamento dos campos de conhecimento envolvidos, mediante abordagens interdisciplinares; e formar pesquisadores capazes de desenvolver pesquisas históricas relativas às linhas de pesquisa/núcleos temáticos.

O ineditismo da temática do grupo e sua característica interdisciplinar demandaram formulação de fundamentação teóricometodológica específica e também interdisciplinar, porém, não eclética. Por esses motivos, a opção mais importante foi a de não buscar definir aprioristicamente uma teoria a ser "aplicada" a todas as pesquisas, mas considerar as contribuições mais adequadas para que se atinjam os objetivos do grupo. Da reflexão sobre essas contribuições derivou opção teórico-metodológica cuja fecundidade explicativa representa o grande desafio aos pesquisadores interessados em buscar a compreensão da história do ensino de língua e literatura no Brasil e cujos princípios estão sintetizados no conceito de "configuração textual", principal eixo articulador de todas as pesquisas desenvolvidas no grupo. Por "configuração textual” designo o conjunto de aspectos inter-relacionados que constituem o sentido de determinado texto.

Nessa perspectiva, o que confere singularidade a um texto é o conjunto de aspectos constitutivos de sua configuração. Tais aspectos e as respectivas perguntas a que respondem são relativos às seguintes opções: temático-conteudísticas (o quê?) e estruturais-formais (como?), projetadas por um determinado sujeito (quem?), que se apresenta como autor de um discurso produzido de determinado ponto de vista e lugar social (de onde?) e momento histórico (quando?), movido por certas necessidades (por quê?) e propósitos (para quê?), visando a determinado efeito em determinado tipo de leitor (para quem?) e logrando determinado modo de circulação e utilização.

Em vista desses princípios, o método de investigação está centrado em abordagem histórica, e os procedimentos metodológicos privilegiados de investigação, comuns a todas as pesquisas 
desenvolvidas no âmbito do GPHELLB, foram assim definidos: localização, recuperação, reunião, seleção e ordenação de fontes documentais (documentos impressos, manuscritos ou obtidos mediante entrevista, produzidos por sujeitos das épocas em estudo ou produzidos por seus pósteros a respeito dessas épocas); elaboração de instrumentos de pesquisa/guias de fontes, contendo a relação de referências das fontes documentais reunidas e selecionadas; e análise da configuração textual, à luz de bibliografia especializada, dos documentos eleitos como emblemáticos em relação aos temas específicos de investigação.

As fontes documentais, por sua vez, abrangem tematizações (livros, teses acadêmicas, artigos, relatos de experiências, memórias orais ou escritas e similares), normatizações (legislação, guias e propostas curriculares e similares) e concretizações (material didático para o aluno e para o professor, textos avulsos e livros de literatura infantil e juvenil, registros de trabalho docente e discente, memórias e similares), todas relativas ao ensino de língua e literatura e produzidas por brasileiros, desde o período colonial até os dias atuais, com ênfase no estado de São Paulo.

As pesquisas desenvolvidas durante os vinte anos de funcionamento desse grupo resultaram em dezenas de trabalhos acadêmico-científicos, em nível de pós-doutorado, doutorado, mestrado, especialização, graduação/iniciação científica, e em dezenas de publicações sob a forma de livros, capítulos de livros, artigos em periódicos e textos em anais de eventos científicos nacionais e internacionais.

Os pesquisadores que se formaram no grupo vêm desenvolvendo pesquisas e formando outros pesquisadores em instituições de ensino e pesquisa do estado de São Paulo ou de outros estados brasileiros.

Também vinculadas ao GPHELLB, desenvolveram-se outras atividades acadêmico-científicas: os projetos integrados de pesquisa: "Repertório documental republicano", entre 1999 e 2003 (CNPq; Fapesp); "Bibliografia brasileira sobre o ensino de língua e literatura no Brasil”, entre 2009 e 2011 (CNPq); e o I SIHELE - Seminário Internacional sobre História do Ensino de Leitura e Escrita - "A 
constituição do campo da história da alfabetização no Brasil” (2010) (Fapesp, Fundunesp, PROPG-Unesp; PROEX-Unesp; Fundepe), de que resultou o livro Alfabetização no Brasil: uma história de sua história (2011), vencedor do 54을 Prêmio Jabuti - Categoria Educação - 2012, e a criação da ABAlf - Associação Brasileira de Alfabetização.

A matriz teórica do GPHELLB e do PPHELLB está sintetizada na pesquisa sobre história do ensino de Língua Portuguesa que iniciei em 1992 e que, após significativos acréscimos e modificações, resultou na tese de livre-docência (Magnani, 1997), publicada no livro Os sentidos da alfabetização: São Paulo - 1876/1994, pela Editora Unesp em 2000

Para o desenvolvimento da pesquisa, formulei as seguintes questões de investigação: o que é o "tradicional" no ensino de língua e literatura? Quando e por que se engendra um tipo de ensino de língua e literatura que passou a ser acusado de "tradicional"? O que representava para a época em que ocorreu seu engendramento? Qual sua relação com a tradição que lhe é anterior? Como se pode explicar a insistente permanência do "ensino tradicional"? Quais os sujeitos que se empenham(vam) na produção do novo e revolucionário? Por que razão e de que maneiras? Qual a relação entre tematizações, normatizações e concretizações produzidas ao longo da história desse ensino? Quais os pontos de vista teóricometodológicos que se utilizaram e se produziram nesse processo?

Os resultados dessa pesquisa vieram preencher uma lacuna no âmbito dos estudos em história da educação e da alfabetização, como aponta Magda Soares na apresentação do livro Os sentidos da alfabetização: São Paulo - 1876/1994. Considerando a necessidade de preencher a lacuna relativa à quase inexistência de estudos históricos sobre alfabetização até aquele momento, na pesquisa mencionada elegi a alfabetização (escolar) como objeto de investigação, não porque essa tenha sido uma escolha prévia, mas porque a ela me conduziram os resultados de pesquisa documental: no Brasil, as discussões sobre alfabetização estão inevitavelmente relacionadas com os processos de escolarização das práticas sociais de leitura e escrita, confor- 
me intensificaram-se e sistematizaram-se no final do século XIX. E, pelos mesmos motivos, escolhi analisar os métodos de ensino inicial de leitura (e escrita) ou métodos de alfabetização - conforme denominações respectivamente utilizadas, de modo predominante, no século XIX e a partir do século XX - e enfatizar, como fontes documentais, cartilhas e livros de leitura em que se concretizam esses métodos.

Como se sabe, os métodos para o ensino inicial e escolarizado da leitura e escrita, ou métodos de alfabetização, podem ser classificados em dois tipos básicos: método sintético, que segue o caminho das menores unidades linguísticas para as maiores, ou seja, da "parte" para o "todo"; e método analítico, que segue o caminho inverso, ou seja, do "todo" para a "parte". Dependendo do que se considere a "parte" - grafema, fonema, sílaba ou palavra - e o "todo" - palavra, sentença, conjunto de sentenças ou texto -, no interior de cada um desses dois tipos básicos de métodos encontram-se variados modos de processuação.

Também, naquela pesquisa e na tese dela resultante, era meus objetivo estudar a história da alfabetização, não a considerando como um "capítulo da história do ensino", mas propondo um novo e necessário campo de conhecimento, envolvendo novo objeto de estudo, ao mesmo tempo autônomo e interdisciplinar. Com tais objetivos, considero que aquela pesquisa representou, de fato, o preenchimento de muitas lacunas e, por isso mesmo, fez ressaltar muitas outras, resultantes de preenchimentos, lá onde quase nada havia. Naquele momento histórico, a pesquisa contribuiu, portanto, para mapear o campo e indicar o muito que ainda havia (e há) a ser feito, tendo, nesse sentido, podido parecer, ela mesma, lacunar, demandando novos preenchimentos.

Assim, com o objetivo de contribuir para a produção de uma história do ensino de língua e literatura no Brasil, abordo na tese de livre-docência a história da alfabetização no Brasil, enfocando a "questão dos métodos" com ênfase na situação do estado de São Paulo, no período compreendido entre 1876 (ano da publicação da Cartilha maternal, escrita pelo poeta português João de Deus) e 1994 (ano de encerramento da pesquisa documental). A partir da 
localização, recuperação, reunião, seleção, ordenação e análise da configuração textual das fontes documentais em que predominam tematizações, normatizações e concretizações relativas a determinado método e representativas da disputa pela hegemonia de um determinado projeto de alfabetização, elegi quatro momentos considerados cruciais para a compreensão desse movimento histórico.

O primeiro momento crucial (1876 a 1890) caracteriza-se pela disputa entre os partidários do então novo método da palavração, que consistia em iniciar o ensino da leitura pela palavra, e os dos antigos métodos sintéticos - alfabético (soletração), fônico, silábico -, que consistiam, respectivamente, em iniciar o ensino da leitura pelos nomes ou pelos sons das letras ou pelas famílias silábicas.

O segundo momento crucial (1890 a meados dos anos 1920) caracteriza-se pela disputa entre defensores do então novo método analítico e os dos antigos métodos sintéticos. Nesse momento, destacou-se a atuação dos professores formados pela Escola Normal de São Paulo (em suas diferentes fases), que foram responsáveis por muitas iniciativas inovadoras e renovadoras da instrução pública republicana, entre as quais a criação da revista Eschola Publica (1896), Revista de Ensino (1902), revista Educação (em 1927, com fusão da Revista da Sociedade de Educação, de 1922, e Revista Escolar, de 1925). Em todas suas iniciativas, esses professores visavam tanto à sistematização e à metodização do ensino quanto à intervenção dos professores nas decisões relativas à instrução. Para isso, defendiam o método analítico para o ensino da leitura e escrita no âmbito de, pelo menos, dois tipos de disputas inter-relacionadas: a disputa entre os defensores dos métodos sintéticos - que, além de defender esses métodos por considerá-los mais rápidos e eficientes do que os analíticos, continuavam produzindo cartilhas neles baseadas - e os defensores do "novo e revolucionário" método analítico para o ensino da leitura; e a disputa entre os defensores do método analítico - "modernos" e "mais modernos" - travada em torno dos diferentes modos de se processar esse método para o ensino da leitura - a palavração, a sentenciação ou a historieta. O método analítico oficializado no estado de São Paulo, nesse momento histórico, foi o método centrado na 
"historieta": conjunto de sentenças enunciadas a partir do estímulo visual gerado pela observação e fixada pela memória e que mantêm nexos lógico-gramaticais entre si.

O terceiro momento crucial (meados dos anos 1920 ao fim dos anos 1970) caracteriza-se pelas disputas entre defensores dos antigos métodos de alfabetização e os dos então novos testes ABC para verificação da maturidade necessária ao aprendizado da leitura e da escrita (criados por Lourenço Filho), de que decorreu a introdução dos "novos" "métodos mistos" para o ensino inicial da leitura e da escrita.

O quarto momento crucial (meados de 1980 aos dias atuais) caracteriza-se inicialmente pelas disputas entre os defensores da então nova teoria construtivista e os dos antigos testes de maturidade e antigos métodos de alfabetização, e, mais recentemente, pela introdução da nova teoria do letramento e pelas discussões sobre a reintrodução do "novo" método fônico e sobre políticas públicas de alfabetização no Brasil.

Em cada um desses momentos encontram-se condensadas as tensões e as contradições relacionadas com as disputas entre o novo/revolucionário e o antigo/tradicional em torno da questão dos métodos de alfabetização, e cada um deles é marcado pela hegemonia de um novo sentido atribuído à alfabetização, com base no qual se funda uma (nova) tradição.

A caracterização dos quatro momentos cruciais inter-relacionando aspectos educacionais, sociais e políticos, assim como a indicação das questões norteadoras da investigação relativas à temática do grupo, foram os principais aspectos a propiciar que, na tese e no livro mencionados, se inspirassem também as pesquisas vinculadas às demais linhas do GPHELLB, além das vinculadas à linha "História da alfabetização". E, em particular no que se refere a esse núcleo temático, as pesquisas no âmbito do grupo passaram a se situar em cada um dos quatro momentos, tendo a tese e o livro passado a constituir a síntese da matriz teórica do grupo e a configurar um subprograma de pesquisa específico. 
Como se pode constatar, ao longo de seus vinte anos de funcionamento, muitos foram os avanços e as contribuições proporcionados pelo GPHELLB, assim como muitas foram as dificuldades e muitos são os desafios ainda a enfrentar. Dentre os principais avanços e dificuldades, podem-se destacar os relacionados com o enfrentamento do desafio representado pelo caráter pioneiro e interdisciplinar da temática do grupo, assim como da fundamentação teórico-metodológica para sua exploração.

Inicialmente, os principais desafios consistiam em justificar a relevância e a pertinência da temática no diálogo com pesquisadores das áreas e campos de conhecimento envolvidos. Como uma forma de lidar adequadamente com essas dificuldades, sem, no entanto, obliterar a especificidade da temática do grupo, as principais opções foram a cuidadosa formulação inicial "pesquisas de fundo histórico", para nomear a abordagem proposta para as pesquisas, e o já explicitado método da análise da configuração textual de documentos, por meio do qual se busca assegurar a abordagem histórica e inter-relacionada dos diferentes aspectos envolvidos na temática.

A partir, sobretudo, da década de 2000, essas dificuldades iniciais foram-se diluindo, por causa da consolidação do campo da história da educação e do prestígio conquistado por pesquisas históricas.

Para esse novo contexto acadêmico-científico, vêm contribuindo também as pesquisas desenvolvidas no GPHELLB, cujos principais avanços podem ser sintetizados na utilização do método de análise da configuração textual, que tem propiciado compreender a importância da análise integrada de todos os aspectos que constituem os sentidos dos documentos, em especial cartilhas de alfabetização, manuais de ensino e programas de formação de alfabetizadores. Esse método tem propiciado, ainda, compreender que analisar esses documentos demanda também dar a conhecer, por meio da exposição dos aspectos de sua configuração, os documentos-fontes - alguns inéditos, ou de difícil localização para fundamentar a interpretação histórica que neles se apresenta e 
avançar na produção de objetos de investigação relativos à história da alfabetização.

Outro avanço significativo são os instrumentos de pesquisa elaborados pelos integrantes do GPHELLB, os quais contêm relação de referências da bibliografia de e sobre autores de cartilhas de alfabetização, livros de leitura e manuais de ensino e têm contribuído significativamente para subsidiar pesquisas correlatas, tanto as que eles mesmos elaboram na continuidade de sua formação acadêmica quanto as de colegas do grupo e as de outros pesquisadores.

Todos os integrantes do grupo vêm desenvolvendo pesquisas que buscam preencher lacunas no conhecimento científico sobre a temática e vêm consolidando o diálogo com pesquisadores brasileiros e estrangeiros, ampliando-se, assim, as reflexões sobre os temas específicos de suas pesquisas e sua contribuição para o alargamento dos campos de conhecimento envolvidos.

No que se refere especificamente à relação entre as pesquisas e os quatro momentos cruciais que proponho para a história da alfabetização no Brasil, elas vêm contribuindo para a caracterização, na longa duração histórica, de conceitos caracteristicamente "brasileiros" de: "alfabetização", como ensino inicial de leitura e escrita na fase inicial de escolarização de crianças, abrangendo alfabetização de jovens e adultos; "cartilha de alfabetização", como concretização de tematizações e normatizações para esse ensino; "manual de ensino", como concretização de saberes sobre conteúdos e métodos para ensinar futuros professores a alfabetizar, sempre de acordo com tematizações e normatizações sobre esse ensino; e "programas de ensino”, como normatizações derivadas de tematizações e norteadores de concretizações para esse ensino.

Essas pesquisas vêm, ainda, aprofundando as possibilidades de problematização das questões iniciais sobre as disputas entre o "novo" e o "tradicional", por meio do aprofundamento da reflexão sobre as relações entre continuidades e descontinuidades, rupturas e permanências na história da alfabetização no Brasil, conforme apresentadas na tese de livre-docência e no livro dela resultante. 
Apesar de serem muitos, ainda, os desafios a enfrentar, desde a criação do GPHELLB, mediante um trabalho integrado e interdisciplinar, vem sendo possível avançar na consecução de seus objetivos.

Além de comemorativo dos vinte anos de criação do grupo, portanto, este livro objetiva contribuir para a compreensão da história do ensino de leitura e escrita no Brasil. Nele encontra-se reunida uma "amostra" da produção do grupo, representada por um artigo de minha autoria e quatorze artigos resultantes de pesquisas em nível de iniciação científica, mestrado e doutorado desenvolvidas por integrantes do GPHELLB, sob minha orientação acadêmica, entre 1996 e 2013. Os resultados das demais pesquisas não deixam, porém, de ser retomados ou citados, já que se vinculam à mesma temática e dialogam entre si, na rede de relações de sentido que se estabelece entre os sujeitos aqui abordados.

Em cada um dos artigos que constituem os capítulos deste livro, problematizam-se os lugares que ocupam nessa história os sujeitos, cujas atuação profissional e produção escrita são representativas das tematizações, normatizações e concretizações para esse ensino, desde o final do século XIX até os dias atuais, tendo, cada um a seu modo, contribuído para a fundação de novas tradições. Situando-se a atuação profissional e produção escrita desses sujeitos nos respectivos momentos históricos do ensino da leitura e escrita no Brasil, objetiva-se propiciar a compreensão do lugar de cada um deles na rede de relações de sentido que se pode estabelecer, do ponto de vista da longa duração histórica. Por esse motivo, optou-se pela apresentação dos capítulos em ordem cronológica, conforme o momento de atuação de cada sujeito dessa história.

Em relação ao "primeiro momento", têm-se os artigos de Luana Grazielle dos Santos e Franciele Ruiz Pasquim, que abordam, respectivamente, a atuação de Thomaz Galhardo (1855-1904) e de Silva Jardim (1860-1891).

Os artigos referentes a sujeitos que atuaram no "segundo momento" são mais numerosos, evidenciando também a efervescência desse momento histórico e sua importância do ponto de vista da 
fundação de nova tradição, cujos efeitos fazem-se sentir também nas discussões atuais sobre o ensino da leitura e da escrita.

Em relação ao "segundo momento", abordam-se os seguintes sujeitos: João Köpke (1852-1926), por Maria do Rosário Longo Mortatti; Ramon Roca Dordal (1854-1938) e Carlos Alberto Gomes Cardim (1875-1938), por Franciele Ruiz Pasquim; Arnaldo de Oliveira Barreto (1869-1925), por Vanessa Cuba Bernardes; Francisco Vianna (1876-1935), por Angélica Pall Oriani; Theodoro de Moraes (1877-1956), por Bárbara Cortella Pereira; e Antonio Firmino de Proença (1880-1946), por Monalisa Renata Gazoli.

Em relação ao "terceiro momento", os sujeitos abordados são: Renato Sêneca Fleury (1895-1980), por Cyntia Grizzo Messenberg; Manoel Bergström Lourenço Filho (1897-1970), por Estela Natalina Mantovani Bertoletti; Antonio D’Ávila (1895-1980), por Thabatha Aline Trevisan; e Bárbara Vasconcelos de Carvalho (1915-2008), por Fernando Rodrigues de Oliveira.

Em relação ao "quarto momento", ainda em curso, abordam-se: Emilia Ferreiro (1937-) e João Wanderley Geraldi (1946-), por Márcia C. O. Mello e por Luzia de F. Paula, respectivamente.

Como se pode constatar por meio dos resultados das pesquisas aqui apresentadas, apesar do muito que fizemos, ainda há temas e problemas para serem explorados. E esperamos que, além de comemorativo, este livro possa ser também convidativo a todos os pesquisadores, professores e estudantes que, assim como nós, tenham interesse em conhecer e estudar o passado e as tradições que constituem os modos de pensar, sentir, querer e agir em relação ao ensino da leitura e da escrita no Brasil.

Marília/SP, agosto de 2014 Maria do Rosário Longo Mortatti 


\section{1 \\ Cartilha da infancia, ${ }^{1}$ De Thomaz GALHARDO (1855-1904) ${ }^{2}$}

Luana Grazielle dos Santos

\section{Introdução}

No primeiro momento da história da alfabetização no Brasil (Magnani, 1997; Mortatti, 2000a), dentre os defensores dos métodos sintéticos, destacou-se o professor Thomaz Paulo do Bom Sucesso Galhardo (1855-1904), natural de Ubatuba (SP) e formado pela Escola Normal de São Paulo (ENSP). Além de livros de leitura, é autor de uma das primeiras "concretizações" do método sintético baseado na silabação, defendido por ele como o mais adequado para o ensino inicial da leitura a crianças. Trata-se de Cartilha da infancia: ensino da leitura, ${ }^{3}$ publicada pela Livraria Francisco Alves (RJ). Com 1a edição presumivelmente na década de 1880, essa cartilha teve sua última edição, a 233ª , em 1992.

1 Nesta e em demais citações de títulos e de trechos de textos apresentadas nos capítulos deste livro, mantém-se, sempre que possível, a ortografia de época [N. O.].

2 Este texto é resultante de pesquisa de iniciação científica, desenvolvida com Bolsa PIBIC/CNPq/Unesp, cujos resultados finais foram apresentados sob a forma de Trabalho de Conclusão de Curso (Santos, 2008a). Artigo com conteúdo semelhante encontra-se em Santos (2007) [N. O].

3 Análise detalhada dessa cartilha encontra-se em Santos (2008a). 
Essa cartilha ocupou um lugar de destaque na educação brasileira, por ter sido adotada pelo governo paulista, e depois por outros estados do Brasil, para ser utilizada em escolas primárias e, também, por ter sido a cartilha que alfabetizou o maior número de brasileiros em sua época. De acordo com Amâncio (2000), essa cartilha foi efetivamente utilizada em escolas primárias dos estados de Minas Gerais, Mato Grosso, Paraná e São Paulo, inclusive na primeira metade do século XX. ${ }^{4}$

O objetivo deste artigo é, portanto, contribuir para a compreensão do lugar de Thomaz Galhardo e sua significativa produção escrita relacionada ao ensino inicial da leitura, tanto naquele momento histórico quanto na educação paulista e brasileira.

\section{Apresentação de Thomaz Galhardo}

\section{Aspectos biográficos e profissionais de Thomaz Galhardo}

Thomaz Paulo Galhardo nasceu na cidade de Ubatuba (SP), em 29 de dezembro de 1855, e morreu aos 49 anos de idade, em 30 de junho de 1904, na cidade de São Paulo (SP). Era filho de José Paulo de Rosa Galhardo e Ana Bernardino Rodrigues Galhardo.

Segundo D'Ávila5 (1984, p.3), “[...] Thomaz Paulo Galhardo, pela felicidade de seu nascimento, adjudicou ao nome a expressão do Bom Sucesso, visto que nascera bem e agradou-lhe noticiar esse evento assim". Porém, o nome com o qual ficou conhecido em sua atuação na educação e administração paulista foi Thomaz Galhardo.

4 Estudo sobre a circulação de cartilhas no estado de Mato Grosso foi desenvolvido por Amâncio (2000), no âmbito do GPHELLB.

5 Informações sobre esse autor encontram-se em texto de Thabatha Aline Trevisan que integra este livro. Estudo minucioso sobre esse autor e sua obra foi desenvolvido por Trevisan $(2003 ; 2007)$. 
Thomaz Galhardo teve uma intensa carreira profissional. Aos 19 anos de idade, foi promotor público interino da Comarca de Santos, onde, em 1871, exerceu também o magistério. Em 1874, com a reabertura da ENSP, em sua segunda fase, Galhardo mudou-se para São Paulo e foi aluno da primeira turma dessa escola, onde se formou, em 1876. Nessa cidade, além de integrar comissões examinadoras, representou o professorado no Congresso Pedagógico do Rio de Janeiro, exerceu o cargo de secretário-geral da Instrução Pública do Estado de São Paulo, ${ }^{6}$ e, a pedido do doutor Cesário Mota, elaborou, em 1892, o Regulamento do Ginásio do Estado e o da Escola Politécnica de São Paulo, tendo recebido, por essa tarefa, elogios da Secretaria da Instrução Pública. Em 1893, Thomaz Galhardo foi o primeiro diretor da recém-inaugurada Escola Politécnica de São Paulo. Dedicou-se ao ensino público, tendo ocupado cargos de importância no magistério paulista.

Presumivelmente em 1880, Thomaz Galhardo escreveu Cartilha da infancia. Depois dessa cartilha, escreveu dois livros de leitura e vários livros didáticos, todos publicados pela Livraria Francisco Alves (RJ) e utilizados em escolas brasileiras desde o século XIX até o final do século XX.

Um de seus livros, Monografia da letra A (1895), foi citado e elogiado por Ruy Barbosa em sua crítica à redação do Código Civil Brasileiro (Chastan, 1992, p.111; No Mundo dos Livros, 1970). Essa monografia foi também comentada e elogiada por Antônio D'Ávila (1984), que afirma que um fato que engrandeceu a "figura do grande mestre" foi a publicação da Monografia da letra A (1895), que era distribuída gratuitamente, pois foi a polêmica do comentário de Galhardo sobre o Código Civil Brasileiro que lhe trouxe prestígio.

Em 1894, Thomaz Galhardo assumiu o cargo de oficial-maior da Secretaria da Instrução Pública de São Paulo, que era subordinada à Secretaria do Interior. Nesse mesmo ano, assinou contrato com

6 Até o momento, não localizei informações sobre as comissões organizadoras de que Galhardo participou, nem as datas em que exerceu o cargo de secretário-geral da Instrução Pública e em que participou do Congresso Pedagógico do Rio de Janeiro. 
a Editora Francisco Alves para a publicação, no ano seguinte, de Cartilha da infancia e de Segundo livro de leitura (Bragança, 2004).

Galhardo recebeu também o grau de Comendador, ${ }^{7}$ outorgado pelo imperador Dom Pedro II por sua relevante participação na educação deste país. Foi sócio-fundador da União Pedagógica e do Instituto Histórico e Geográfico de São Paulo. Aposentou-se no cargo de subdiretor da Secretaria do Interior de São Paulo em 18 de novembro de 1897.

Em 1901, Thomaz Galhardo passou por dificuldades financeiras e vendeu os direitos de propriedade de Cartilha da infancia à Livraria Francisco Alves. Três anos depois, em 1904, ano de seu falecimento, "[...] Thomaz Galhardo ainda mesmo no descanso de sua aposentadoria, continuava a dedicar-se activamente, desempenhando um lugar de autoridade policial, no distrito de sua moradia” (Diário Popular, 1904,).

\section{Aspectos da produção escrita de Thomaz Galhardo ${ }^{8}$}

A produção escrita de Thomaz Galhardo iniciou-se, presumivelmente, na década de 1880, com a publicação da única cartilha de sua autoria, Cartilha da infancia: ensino da leitura, publicada pela Livraria Francisco Alves.

Como complemento à cartilha, Galhardo escreveu dois livros de leitura, ambos publicados pela Livraria Francisco Alves: Segundo livro de leitura: para a infancia, com 1a edição em 1905 e que foi publicado, em 1934, também com o título: Na escola e no lar: segundo livro de leitura para infância; e Terceiro livro de leitura: para a infancia, que teve sua 1a edição em 1902.

Os livros didáticos de Galhardo foram muito utilizados nas escolas brasileiras e tiveram grande aceitação por parte de alunos e professores, como se pode constatar pelo grande número de edições

7 Até o momento, não localizei a data em que Thomaz Galhardo recebeu essa homenagem.

8 No Instrumento de Pesquisa (Santos, 2008b) foram reunidos os textos a que me refiro neste tópico. 
de sua cartilha e de seus livros de leitura. Cartilha da infancia, que como informado, teve sua 1ㄹ edição, presumivelmente, em 1880, mais de um século depois, em 1992, estava em sua 233a edição; e Terceiro livro de leitura, que teve sua 1a edição em 1902, alcançou, em 1929, sua $27^{\text {a }}$ edição. ${ }^{9}$

\section{Apresentação de Cartilha da infancia ${ }^{10}$}

A Cartilha da infancia: ensino da leitura foi modificada e ampliada, em 1890, pelo professor Romão Puiggari, discípulo de Galhardo, e teve sua $2^{\mathrm{a}}$ edição em 1891, publicada pela Teixeira \& Irmão Editores (SP). A Editora Paulo de Azevedo Ltda. (SP) pu-

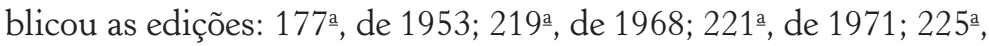
de 1978; e 228a de 1987. A $228^{a}$ edição dessa cartilha foi publicada também pela Editora Francisco Alves no mesmo ano. Essa cartilha foi adotada oficialmente pelo governo paulista e pelo de outros estados do país.

Destaco a importante ligação de Thomaz Galhardo com o livreiro e editor Francisco Alves, ${ }^{11}$ que, na inauguração da nova filial em São Paulo, o homenageou nomeando uma das "seções" da nova livraria com o nome de Thomaz Galhardo.

Para justificar a escolha do método silábico, que serviu de base para sua cartilha, Galhardo (1939, p.6) destaca: "Dos três métodos de ensino da leitura, antigo ou da soletração, moderno ou da silabação, e modernissimo ou da palavração, escolhemos o meio termo, sôbre cujas bases foi escrito o presente sistema".

9 Análise da permanência de cartilhas de alfabetização na cultura escolar brasileira pode ser encontrada, sobretudo, em Mortatti (2000b).

10 Como não foi possível localizar, até o momento, informações exatas sobre a data da 1 a edição de Cartilha da infancia: ensino da leitura, optei por indicar apenas a década de 1880 como data provável dessa edição, conforme consta em alguns dos documentos que consultei.

11 Detalhes sobre a publicação da cartilha pela Francisco Alves encontram-se em Santos (2008a). 
Essa cartilha caracteriza-se como uma "concretização" do método da silabação ou silábico, considerado por Galhardo como "moderno" e "solução intermediária" mais adequada ao ensino da leitura e escrita às crianças naquele momento histórico. Trata-se de método sintético, de acordo com o qual se inicia o ensino da leitura com a apresentação das vogais formando famílias silábicas.

A cartilha contém 33 lições, iniciando-se com apresentação alternada das vogais, formando ditongos. Na segunda lição é apresentada a consoante "v", seguida da família silábica, vocábulos e depois o exercício, que é constituído por um conjunto de sentenças, cujas palavras têm as sílabas separadas por hífen.

A estrutura das lições mantém-se inalterada, do começo ao final da cartilha. Em cada lição é apresentada, no alto da página, a letra, seguida de sua classificação fonética entre parênteses. Logo depois dessa letra são apresentadas as famílias silábicas, repetidas, em sua maioria, três vezes e em ordem diferenciada; e, em seguida, são apresentados vocábulos e exercícios para a leitura. Da 2ª lição até a 32a mantém-se essa estrutura.

A partir da 25a lição, aparecem nas sentenças dos exercícios pontos de interrogação e alguns outros sinais de pontuação, como vírgula, ponto e vírgula, dois-pontos. $\mathrm{O}$ ponto-final foi utilizado somente nas sentenças apresentadas nas lições finais da cartilha.

Antes da 33a lição, na página 49, é apresentado o alfabeto em uma ordem aleatória, primeiramente em letras minúsculas e depois em letras maiúsculas. Ao final de cada lição são apresentados exercícios para leitura, que se caracterizam como conjuntos de sentenças com todas as palavras separadas em sílabas.

Nas páginas finais da cartilha são apresentadas seis pequenas narrativas: duas com todas as palavras separadas em sílabas ("A escola" e "A carta"), e quatro com sentenças cujas palavras não estão separadas em sílabas ("A oração", "A boca”, "Estradas de ferro" e "Os filhos do pescador”). Há, ainda, três poemas, sendo o primeiro sem título, o segundo intitulado "O amanhecer", e o terceiro intitulado "I - Amanhece..." (extraído do Segundo livro de leitura, de Thomaz Galhardo) 
Essas narrativas e esses poemas abordam assuntos relacionados à necessidade do bom comportamento das crianças na escola e em casa.

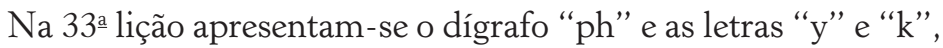
cada uma seguida de palavras separadas em sílabas. Essa lição é apresentada por último na cartilha, após os poemas, provavelmente devido a sua complexidade.

\section{Considerações finais}

No momento histórico em que foi publicada a primeira edição de Cartilha da infancia, devido ao grande número de analfabetos, havia uma grande preocupação com a educação, em relação a como solucionar os problemas de analfabetismo e melhorar o ensino da leitura e da escrita.

A fim de realizar mudanças na educação brasileira, foi promulgada, em 1879, a reforma "Leôncio de Carvalho" (Decreto de 19 de abril de 1879), que, de acordo com Ribeiro (1979, p.66), “[...] é difundida e algumas (poucas) consequências práticas acontecem”. Ainda de acordo com essa autora, "[...] Leôncio de Carvalho entendia que muito havia a ser feito para imprimir um impulso à educação" (ibidem, p.66).

Dentre as medidas tomadas por Leôncio de Carvalho, destaco a Liberdade de Ensino, isto é, " [...] a possibilidade de todos os que se sentissem capacitados exporem suas ideias segundo o método que lhes parecesse mais adequado" (ibidem, p.66).

Pelo exposto, pode-se concluir que Cartilha da infancia foi elaborada seguindo princípios do método sintético, baseado na silabação e defendido pelo autor da cartilha como o mais eficiente para o ensino da leitura naquele momento histórico, assim como por seu discípulo, Romão Puiggari (1934, p.4), que afirma que o método de leitura, organizado pelo professor Thomaz Galhardo:

[...] tem oferecido vantagens extraordinárias sôbre todos os métodos até hoje empregados em nossas escolas. E isto atestado por 
todos quantos o têm empregado. Demonstra-o a grande aceitação que tem tido, obrigando os ativos editores a fazerem nova tiragem.

É importante ressaltar, ainda, que Puiggari, também autor de livros de leitura, reformulou e "revitalizou" a Cartilha da infancia em 1890, após, portanto, a proclamação da República e concomitantemente a um intenso movimento dos "reformadores" da instrução pública paulista, o qual culminou, entre outros importantes aspectos, com a implantação oficial do método analítico para o ensino da leitura nas escolas públicas do estado, principal característica do segundo momento da história da alfabetização no Brasil, proposto por Magnani (1997) e Mortatti (2000a).

Assim, apesar de se basear em método sintético, apesar da crescente concorrência com tantas outras cartilhas que foram publicadas nesse segundo momento, apesar de todas as novas disputas em torno dos métodos de alfabetização e apesar de outras novas urgências sociais e políticas, essa cartilha continuou a ser largamente utilizada em escolas primárias brasileiras até o final do século XX.

\section{Referências bibliográficas}

BRAGANÇA, A. Francisco Alves, uma editora sesquicentenária (18542004). In: IV ENCONTRO DOS NÚCLEOS DE PESQUISA DA INTERCOM, 2004, Porto Alegre. Disponível em: <http://reposcom.portcom.intercom.org.br/bitstream/1904/17513/1/R0631-1. pdf $>$. Acesso em: jan. 2007.

CHASTAN, L. São Paulo - Litoral Norte: caiçaras e franceses. São Paulo: Ateniense, 1992. v. VIII.

D'ÁVILA, A. Galeria de patronos de escolas (32): Professor Thomaz Galhardo. Jornal dos professores. São Paulo, p.3, nov. 1984.

FRADE, I. C. A. da S.; MACIEL, F. I. P. A história da alfabetização: contribuições para o estudo das fontes. In: REUNIÃO ANUAL DA ANPEd, 29. 2006, Caxambu, MG. Disponível em: <http://www. anped.org.br/reunioes/29ra/trabalhos/trabalho/GT10-1955--Int. pdf>. Acesso em: fev. 2007. 
GALHARDO, T. Sessão de inauguração da Escola Polyitechnica. São Paulo: Typographia Viúva Martha Wienke, 1894. 27p.

. Terceiro livro de leitura: para a infancia. 1.ed. Rio de Janeiro: Livraria Francisco Alves, 1902.

Segundo livro de leitura: para a infancia. 19.ed. Rio de Janeiro: Livraria Francisco Alves, 1910.

Monografia da letra a. 3.ed. São Paulo: C. Teixeira, 1912.

. Cartilha da infancia: ensino da leitura. 141.ed. Rio de Janeiro:

Livraria Francisco Alves, 1939.

HALLEWELL, L. Francisco Alves. In:__. O livro no Brasil: sua história. Tradução de Maria da Penha Villa-Lobos. São Paulo: Editora da Universidade de São Paulo, 2005, p.269-94.

HARRIS, T. L.; HODGES, R. E. (orgs.). Dicionário de alfabetização: vocabulário de leitura escrita. Tradução de Beatriz Viégas-Faria. Porto Alegre: Artmed, 1999.

LEÃO, A. B. Francisco Alves e a formação da literatura infantil. In: SEMINÁRIO BRASILEIRO SOBRE LIVRO E HISTÓRIA EDITORIAL, 1., 2004, Rio de Janeiro. Disponível em: <http://www.livroehistoriaeditorial.pro.br/pdf/andreaborgesleao.pdf>. Acesso em: jan. 2006.

MAGNANI, M. do R. M. Os sentidos da alfabetização: a "questão dos métodos" e a constituição de um objeto de estudo (São Paulo: 1876/1994). Presidente Prudente, 1997. 389f. Tese (Livre-Docência em Metodologia do Ensino de 1ํGrau: Alfabetização) - Faculdade de Ciência e Tecnologia, Universidade Estadual Paulista.

MELLO, L. C. Dicionário de autores paulista. São Paulo: Irmãos Andrólis, 1954. (Comissão do VI Centenário da cidade de São Paulo.)

MERECIDA HOMENAGEM A UM EDUCADOR: professor Thomaz Galhardo. Jornal a gazeta. São Paulo, 30 jun. 1966.

MORTATTI, M. do R. M. Notas sobre linguagem, texto e pesquisa histórica em educação. História da Educação, Pelotas, v.6, p.69-77, out. 1999.

Os sentidos da alfabetização (São Paulo/1876-1994). São Paulo: Editora Unesp, 2000a.

Cartilha de alfabetização e cultura escolar: um pacto escolar. Cadernos CEDES, ano19, n.52, p.41-54, nov. 2000b.

Ensino de língua e literatura no Brasil: repertório documental republicano. Marília, 2003. (Digitado).

. Educação e letramento. São Paulo: Unesp, 2004. 
NEGROLOGIA: Thomaz Galhardo. Diário popular, São Paulo, ano 20, n.6.416, p.2, 30 jun. 1904.

NO MUNDO DOS LIVROS: Tomás Galhardo, 1970. (Recorte de jornal arquivado no Instituto de Pesquisas e Estudos Educacionais "Professor Sud Mennucci”). [S.1], [s.n.].

NOTÍCIA SOBRE O ENSINO NO ESTADO DE SÃO PAULO. (1913).

PFROMM NETO, S.; DIB, C. Z.; ROSAMILHA, N. Cartilhas, gramáticas, livros de texto. In: O livro na educação. Rio de Janeiro: Primor;INL, 1974, p.153-204.

PROF. THOMAZ GALHARDO. [S.1], [s.n], 1985. (Recorte de jornal referente à história de Ubatuba).

PUIGGARI, R. O método de... In: GALHARDO, T. Cartilha da infancia: ensino da leitura. 141.ed. Rio de Janeiro: Livraria Francisco Alves, 1939, p.4.

RAZZINI, M. de P. G. A Livraria Francisco Alves e a expansão da escola pública em São Paulo. In: SEMINÁRIO BRASILEIRO SOBRE LIVRO E HISTÓRIA EDITORIAL, 2004, Rio de Janeiro. Anais eletrônicos. Disponível em: <http:// www.livroehistoriaeditorial.pro. $\mathrm{br} / \mathrm{pdf} /$ marciadepaularazzini.pdf>. Acesso em: 15 ago 2008.

REVISTA DO PROFESSOR. [S.1]. n.8, p.18, maio 1951, ano VIII.

RIBEIRO, M. L. S. História da educação brasileira: a organização escolar. São Paulo: Cortez \& Moraes, 1979.

RIBEIRO, N. R. Um estudo sobre A leitura analytica (1896), de João Köpke. Marília, 2001. 66f. Trabalho de Conclusão de Curso (Graduação em Pedagogia) - Faculdade de Filosofia e Ciências, Universidade Estadual Paulista.

SACRAMENTO, A. V. A. Dicionário bibliográfico brazileiro. 7v. Rio de Janeiro: Imprensa Nacional, 1902.

SANTOS, L. G. dos S. Um estudo sobre a Cartilha da infância (188?), de Thomaz Galhardo. Revista de Iniciação Científica da FFC, v.7, p.33242, 2007.

. Um estudo sobre Cartilha da infância (1880), de Thomaz Galhardo. Marília, 2008a. 63f. Trabalho de Conclusão de Curso (Graduação em Pedagogia) - Faculdade de Filosofia e Ciências, Universidade Estadual Paulista.

Bibliografia de e sobre Thomaz Galhardo: um instrumento de pesquisa. Marília, 2008b. (Digitado).

SOARES, M. B.; MACIEL, F.. Alfabetização. Brasília: MEC/Inep/ Comped, 2000. 
TERCEIRO CENTENÁRIO DE UBATUBA: Arquivo histórico. [S.1], [s.n.],1937.

TREVISAN, T. A. Um estudo sobre Práticas escolares (1940), de Antônio d'Ávila. Marília, 2003. 66f. Trabalho de Conclusão de Curso (Graduação em Pedagogia) - Faculdade de Filosofia e Ciências, Universidade Estadual Paulista.

A Pedagogia por meio de Pedagogia: teoria e prática (1954), de Antônio d'Ávila. Marília, 2007. 165f. Dissertação (Mestrado em Educação) - Faculdade de Filosofia e Ciências, Universidade Estadual Paulista. 


\section{2 \\ Antonio da SilVA JARdim (1860-1891) \\ NA HISTÓRIA DO ENSINO DE LEITURA \\ E ESCRITA NO BRASIL ${ }^{1}$}

Franciele Ruiz Pasquim

\section{Introdução}

O anseio por mudanças sociais e políticas no período imperial brasileiro intensificou-se nas duas décadas que antecederam a instauração do regime republicano, com repercussões importantes para a instrução pública e para o ensino inicial de leitura e escrita a crianças. Segundo Mortatti (2000, p.51), o “[...] final da década de 1870 e a década de 1880, sobretudo na província de São Paulo, são momentos ricos de efervescência de ideias renovadoras em relação ao ensino da leitura e à nacionalização do material didático”.

É nesse contexto político e social que Mortatti (ibidem, p.25) situa o "primeiro momento" da história da alfabetização no Brasil (1876 a 1890), marcado pela “[...] disputa entre o então 'novo' método João de Deus para o ensino da leitura, baseado na palavração, e os 'antigos' métodos sintéticos - soletração e silabação - em que se baseiam as primeiras cartilhas escritas por brasileiros”. E é

1 Este texto é resultante de pesquisa de mestrado, desenvolvida com bolsa Fapesp, cujos resultados finais foram apresentados sob a forma de dissertação de mestrado (Pasquim, 2013) [N.O.]. 
nesse momento histórico que "o método João de Deus", contido na Cartilha maternal ou arte da leitura, escrita pelo poeta português João de Deus e publicada em Portugal em 1876, "[...] passa a ser divulgado sistemática e programaticamente no Brasil [...] por Antonio da Silva Jardim, positivista militante e professor de Português na Escola Normal de São Paulo" (ibidem, p.25).

A importância do pensamento e da atuação de Antonio da Silva Jardim (1860-1891), não se limita à divulgação desse método de ensino da leitura. Essa, porém, é sua faceta menos conhecida, comparativamente à do propagandista do regime republicano, que tem sido objeto de estudos realizados por brasileiros. O objetivo deste texto, portanto, é contribuir para a compreensão de aspectos ainda pouco explorados de seu pensamento sobre o ensino inicial da leitura e da escrita, assim como de sua contribuição para a reflexão sobre a necessidade de pensar o ensino inicial de leitura e escrita não como questão meramente didático-educacional, mas, sobretudo, como questão política, econômica, cultural e social.

\section{Aspectos da vida, formação e atuação profissional}

Antonio da Silva Jardim nasceu no dia 16 de agosto de 1860, na cidade de Capivari, na província do Rio de Janeiro, atual município de Silva Jardim. ${ }^{2}$ Era filho de Gabriel da Silva Jardim³ e de Felismi-

2 No dia 9 de agosto de 2010, o município de Silva Jardim comemorou o sesquicentenário de nascimento de seu patrono. E, durante as comemorações, foram organizadas exposições e premiação dos vencedores dos projetos "Meu bairro" e "História da minha cidade". Houve, ainda, premiação das melhores redações sobre "Os republicanos". Disponível em: <http://www.silvajardim.rj.gov.br/index.php?option=com_content $\&$ view $=$ article $\& i d=95 \&$ Ite mid=2>. Acesso em: 30 set. 2012.

3 Gabriel Jardim, "[...] nascido em 2 de julho de 1841, casou-se aos 18 annos, entregando-se aos misteres ruraes até 1865, em que por instancia de amigos fundou uma escola particular, que aproveitou á infancia de Silva Jardim" (Leão, 1895, p.5). 
na Leopoldina de Mendonça Jardim, ambos pequenos lavradores (Leão, 1895, p.4). Silva Jardim teve contato com as primeiras letras na infância, pois seu pai era também professor e ensinava os rudimentos da leitura e da escrita em sua casa.

Conforme apontam seus biógrafos, Silva Jardim, por ter desenvolvido o gosto pelos estudos, aos 11 de idade já ensinava os colegas de classe quando seu pai precisava se ausentar.

Ainda durante sua infância, apesar das dificuldades econômicas pelas quais seu pai passava, Silva Jardim, por ser um aluno muito dedicado, "[...] foi para Niterói fazer os estudos secundários. Ali contraiu varíola benigna, que lhe deixou marcas no rosto por toda vida. Após a cura, retomou os estudos no colégio secundário Silva Pontes [...]" (Guzzo, 2003, p.12).

Em 1874, com 14 anos, Silva Jardim passou a estudar no Colégio Mosteiro de São Bento, ${ }^{4}$ em Niterói (RJ), onde recebeu educação católica. No ano seguinte, em 1875, estudou no externato "Jasper", 5 tendo enfrentado dificuldades financeiras que ameaçavam sua permanência nessa instituição. A fim de complementar a renda familiar e pagar as despesas com seus estudos, Silva Jardim auxiliou o ex-professor Jasper L. Harben ${ }^{6}$ nas aulas particulares de Língua Inglesa (ibidem, p.13).

Entre 1875 e 1878, Silva Jardim iniciou os estudos preparatórios para o curso de Direito no Rio de Janeiro (RJ) e teve como colega o poeta Raimundo Corrêa. No ano de 1878, mudou-se para São Paulo e ingressou, com 18 anos incompletos, na Faculdade de Direito de São Paulo (SP). Nesse período, Silva Jardim

4 O Colégio de São Bento foi fundado pelos monges do mosteiro de São Bento, em 1858. Trata-se de uma instituição educativa católica beneditina para meninos. Disponível em: <http://www.osb.or.br/mosteiro/index.php>. Acesso em: 22 nov. 2012.

5 Não localizei informações, até o momento, sobre essa instituição.

6 Jasper L. Harber foi diretor do externato "Jasper" e autor do livro Prosódia ingleza: novo methodo para aprender a pronunciar e fallar com facilidade todas as palavras da lingua ingleza, publicado em 1878 (Revista Ilustrada, 1878, p.7). 
[... fez parte da Bucha ${ }^{7}$ quando estudante, tendo mesmo servido de intermediário entre ela e a Maçonaria, juntamente com Teófilo Dias. Daí os elogios que recebeu do "bucheiro" Rangel Pestana [...] Como todos de sua geração, contudo, sofreu influência das variadas sociedades secretas então atuantes nos meios acadêmicos, que se refletiram mais tarde em suas atividades propagandísticas. (Lima, 1987, p.46)

Segundo Carvalho (2010, p.32), a Maçonaria “[...] no passado emprestou a sua organização para um país que não possuía partidos políticos”. O século XIX foi marcado pela atuação de muitos maçons, pois "[...] era grande a efervescência nas Lojas e nos clubes republicanos de inspiração maçônica, destacando-se, nesse período, muitos maçons civis, que seriam chamados de "republicanos históricos'8: [...] Silva Jardim" (ibidem, p.42-3).

O ingresso na Faculdade de Direito de São Paulo representou um marco na trajetória intelectual de Silva Jardim. Além de confirmar sua notável capacidade e inteligência para os estudos, o ingresso na vida acadêmica contribuiu para definir seu perfil ideológico e político. Segundo Fernandes (2008, p.16), a estada de Silva Jardim nessa instituição

[...] foi de fundamental importância para sua formação, não só pela aprendizagem acadêmica propriamente dita, mas, principalmente

7 Entre 1828 e 1832, foi fundada a "Burschenschaft", por Júlio Frank. A Bucha, como ficou conhecida, tinha como integrantes alguns estudantes do Curso Anexo da Academia de Direito. Essa sociedade de jovens era um tipo de maçonaria "secreta, liberal e filantrópica" em prol das ideias liberais e republicanas. Além disso, auxiliava no pagamento de despesas dos estudos de alunos mais pobres (Montoyama, 2006, p.75).

8 Carvalho (2010, p.42-3) destaca, também, a atuação de "Quintino Bocayuva (fundador do jornal A República e futuro Grão-Mestre do GOB), Campos Sales (futuro Presidente da República), Prudente de Moraes (primeiro presidente civil da República), Silva Jardim, Rangel Pestana, Francisco Glicério, Américo de Campos, Pedro de Toledo, Américo Brasiliense, Ubaldino do Amaral, Aristides Lobo, Bernardino de Campos e outros". 
pela inserção que conseguiu junto à elite intelectual e política do país [...]. (grifos meus)

Fundada em 1827, poucos anos após a Independência do Brasil, a Faculdade de Direito de São Paulo contribuiu para o desenvolvimento da nação brasileira e representava a elite intelectual e política do país. Além disso, foi um polo de formação de bacharéis, e muitos deles se tornaram futuros governantes e administradores públicos. ${ }^{9}$

Foi também no clima da vida acadêmica que Silva Jardim conheceu e aderiu aos preceitos do Positivismo de Auguste Comte. ${ }^{10}$ Inicialmente, Silva Jardim esteve vinculado aos positivistas ortodoxos, que "[...] queriam um presidente forte, um cérebro ativo na chefia do Estado" (Bosi, 1992, p.237), porém, algumas tensões de ordem política e social fizeram-no optar pelas ideias do Evolucionismo, ${ }^{11}$ que, assim como ele, defendiam "reformas espontâneas, lentas e graduais" (ibidem, p.237).

No período em que Silva Jardim permaneceu na Faculdade de Direito de São Paulo, seus autores preferidos eram Luciano Cordeiro, ${ }^{12}$

9 Essas informações foram extraídas da seção "História" do site da Faculdade de Direito de São Paulo. Disponível em: <http//:www.diretiro.usp.br/faculdade/index_faculdadehistoria01.php>. Acesso em: $10 \mathrm{dez} .2012$.

10 Isidore Auguste Marie Xavier Comte nasceu em Montpellier em 19 de janeiro de 1789 e faleceu em Paris no dia 5 de setembro de 1857. A essência do pensamento comtiano é a "humanidade, ciência, síntese e fé" (Ribeiro, 1988, p.8)

11 Como se sabe, o Evolucionismo é uma corrente filosófica que se desenvolveu na Europa, ao longo do século XIX, a partir dos estudos de Jean-Baptiste de Lamarck (1744-1829) e Charles Darwin (1809-1882). Embora haja diferentes vertentes do Evolucionismo, todas elas partem do princípio de que a evolução (adaptação às alterações ocorridas no meio ambiente) é uma condição natural de todos os seres. Além de Darwin e Lamarck, outros importantes representantes do Evolucionismo foram Hebert Spencer (1820-1903) e Teilhard de Chardin (1881-1955) (Japiassú; Marcondes, 2008).

12 Luciano Baptista Cordeiro de Sousa, nascido em Mirandela, Portugal, em 1844, foi um importante escritor, historiador e geógrafo português. Em 1867, diplomou-se em Letras pelo Curso Superior de Letras de Lisboa. Concomitantemente a sua formação, serviu à Marinha portuguesa, o que lhe rendeu, após sua diplomação, a indicação, pelo Ministério de Guerra de Portugal, o cargo de professor de Literatura e Filosofia do Real Colégio Militar de Portu- 
Sainte-Beuve, ${ }^{13}$ Planche,${ }^{14}$ Taine ${ }^{15}$ e Teófilo Braga ${ }^{16}$ (Lima, 1987, p.41).

Apesar do seu temperamento intempestivo e contrário ao regime monárquico, que considerava um entrave para a modernização do país e causa primária de seu atraso, Silva Jardim conquistou amizades importantes (Leão, 1884). Com espírito combativo, es-

gal. Ao longo de sua atuação profissional, além de ter lecionado nesse Colégio, Luciano Cordeiro fundou, em 1876, a Sociedade de Geografia de Lisboa; foi deputado, entre 1882 e 1884; e proferiu palestras em países da Europa e da África. Aos 56 anos de idade, Luciano Cordeiro faleceu em 1900, em Lisboa (Machado, 1891).

13 Charles Augustin Sainte-Beuve, nascido em Bolonha, França, em 1804, consagrou-se como escritor e estudioso da literatura francesa. Diplomado médico pela Escola de Medicina de Paris, Sainte-Beuve não seguiu a carreira médica. Logo após se diplomar, passou a atuar no jornal parisiense Le Globe, onde conheceu, entre outros, o escritor Victor Hugo. A partir de sua experiência profissional nesse jornal, Sainte-Beuve passou a escrever romances, poemas e estudos de crítica literária. No âmbito de sua produção, o livro de crítica Port-Royal, publicado entre 1840 e 1859, em cinco volumes, é um dos mais conhecidos e estudados pelos estudiosos da crítica literária francesa. Sainte-Beuve morreu em Paris, em 1869 (Encyclopédie..., s.d).

14 Não localizei, até o momento, informações sobre esse autor.

15 Hippolyte Adolphe Taine, nascido em Vouziers, França, em 1828, foi um dos membros da Academia Francesa, tendo se destacado no âmbito de sua atuação profissional como crítico e historiador francês. Diplomado pela Escola Normal de Paris, em 1848, Hippolyte Taine atuou como professor da Escola de Belas-Artes de Paris e escreveu um conjunto significativo de livros sobre história e crítica da literatura francesa. No âmbito de sua atuação profissional, Hippolyte Taine ficou conhecido como um importante disseminador do Positivismo na França. Aos 65 anos de idade, Hippolyte Taine morreu em Paris, em 1893 (Larousse, s.d.).

16 Joaquim Teófilo Fernandes Braga, nascido em Ponta-Delgada, Portugal, em 1843, diplomou-se bacharel em Direito, em 1867, e doutorou-se também em Direito, em 1868. No âmbito de sua atuação profissional, Teófilo Braga exerceu o cargo de professor do Curso Superior de Letras de Lisboa, onde tomou contato mais direto com as ideias do Positivismo de Auguste Comte. Além de atuar como professor, Teófilo Braga também atuou como colaborador de jornais portugueses, escreveu livros literários e sobre história e crítica da literatura europeia. Teófilo Braga morreu em Lisboa, em 1924, aos 81 anos de idade (PortugalO, s.d.) 
creveu, com o poeta Valentim Magalhães, ${ }^{17}$ os folhetos Ideias de moço e Crítica escada abaixo, nos quais expuseram seus ideais republicanos e críticas aos monarquistas; e $O$ General Osório, ${ }^{18}$ no qual fizeram uma homenagem póstuma a esse general.

Em 1878, quando cursava o primeiro ano de faculdade, Silva Jardim conheceu Ana Margarida de Andrada, filha de Martim Francisco Ribeiro de Andrada, ${ }^{19}$ que era conselheiro e professor de Direito Eclesiástico da Faculdade de Direito de São Paulo.

Esse namoro possibilitou a Silva Jardim ampliar ainda mais seu círculo de amizades, e, por esse motivo, conheceu o professor Inglês de Sousa. ${ }^{20} \mathrm{O}$ estabelecimento de relação de amizade com essa importante figura da época rendeu a Silva Jardim algumas ascensões importantes, como sua nomeação, no dia 2 de agosto de 1880, a secretário e professor do curso primário do sexo masculino na escola primária anexa à Escola Normal de São Paulo (ENSP), e o convite para atuar como redator e revisor literário do jornal Tribuna Liberal, de São Paulo.

A atuação de Silva Jardim como secretário da ENSP e professor do curso primário anexo contribuiu para suas aspirações e propósitos em prol da modernização da educação do Brasil. Nessa institui-

17 AntônioValentim da Costa Magalhães nasceu no dia 16 de janeiro de 1859 e faleceu no dia 17 de maio de 1903. Bacharelou-se em Direito pela Academia de Direito de São Paulo em 1881. Foi poeta, romancista, dramaturgo, crítico e jornalista brasileiro (Behar,198?).

$18 \mathrm{O}$ folheto $O$ General Osório foi comercializado, e todo o dinheiro arrecadado com sua venda foi destinado à construção de um monumento em homenagem ao falecido General Osóri. (Jornal A Constituinte, 1879).

19 Martim Francisco Ribeiro de Andrada diplomou-se em filosofias e matemáticas, na Universidade de Coimbra (Portugal). Em 1821 iniciou sua carreira política como secretário do governo provisório de São Paulo. Em 1822 foi ministro da Fazenda. Em 1823 foi eleito como deputado de sua província para a Assembleia Constituinte de 1823. Faleceu em 1844 (Vainfas, 2008, p.527).

20 Herculano Marcos Inglês de Sousa nasceu em 1853, na cidade de Óbidos, no estado do Pará, e morreu em 1918, no Rio de Janeiro. Formado em Direito, foi presidente do Espírito Santo e do Maranhão. Foi professor da Universidade Federal do Rio de Janeiro e membro-fundador da Academia Brasileira de Letras (Moisés, 2001, p.42). 
ção, era responsável por formar professores primários para o ensino da leitura e da escrita, e aí encontrou a possibilidade de combater o analfabetismo no país (Mortatti, 2000).

Como professor da seção masculina do curso primário anexo à ENSP, motivado pelas inovações educacionais da época, Silva Jardim

[...] tornou-se partidário da cartilha de João de Deus, que se ajustava às suas concepções positivas. O livro ensinava a ler pelo método da palavração, isto é, não por meio de sílabas, nem soletrando, e sim logo através de palavras completas, das mais simples às mais complexas. (Queiroz, 1967, p.50)

Os cargos ocupados por Silva Jardim na ENSP muito contribuíram para sua permanência na faculdade de Direito, pois, além de pagar seus estudos, podia ajudar seus pais. Assim, em abril de 1882, aos 22 anos de idade, Silva Jardim formou-se bacharel em Ciências Sociais e Jurídicas pela Faculdade de Direito de São Paulo.

Nesse mesmo ano, foi convidado por Inglês de Sousa, então presidente da província do Espírito Santo, a propagar o "novo método" de ensino - o método "João de Deus" — por meio de conferências públicas sobre as vantagens desse método para o ensino da leitura, o qual já utilizara quando ainda era professor do curso primário anexo à ENSP.

Entre os dias 18 e 28 de julho de 1882, Silva Jardim permaneceu em Vitória, capital da província do Espírito Santo, para divulgar esse novo método de ensino, conforme as cláusulas do contrato acordado com Inglês de Sousa:

1ำ a propagar o methodo JOÃO DE DEUS, lecionando gratuitamente a todas as pessoas que o desejassem aprender; 20 a fazer sete conferencias publicas, justificando a importância do referido methodo e sua utilidade; $3^{\circ}$ a abrir um curso publico diario com 42 licções para professores, professoras e mais pessoas; 4으 a leccionar em casas particulares, sem remuneração alguma, contanto que o 
tempo gasto com todas as licçoes não excedesse a sete horas por dia; 5 a apresentar no fim do curso um relatório circunstanciado de todos os meus trabalhos, incluindo noticias detalhadas sobre o resultado que tivesse obtido n'esta Provincia com meu curso diario. (Jardim, 1882, p.4)

Além das conferências, Silva Jardim ensinava em casas particulares dessa cidade e promovia cursos diários para ensinar os professores a ensinar leitura pelo método "João de Deus". Essas conferências davam-lhe grande prestígio. Por outro lado, porém, Inglês de Sousa recebeu críticas negativas por tê-lo convidado a proferir essas conferências nessa província.

Segundo Gontijo e Gomes (2012, p.82), o motivo pelo qual Inglês de Sousa convidou Silva Jardim para divulgar o método "João de Deus" na província do Espírito Santo estava relacionado a dois fatores: aquele já conhecia o trabalho realizado por este no curso primário anexo à ENSP; e Inglês de Sousa considerava "defeituoso e atrasado" o "método de primeiras letras" (soletração), adotado pela província do Espírito Santo.

Diante dessas críticas, Inglês de Sousa justificou a vinda de Silva Jardim atribuindo a esse professor a função de divulgar um método eficaz para o ensino da leitura, que pudesse contribuir para a reforma da instrução pública primária na província do Espírito Santo. No entanto, a ida de Silva Jardim àquela província causou certo desconforto entre os redatores dos jornais A Província do Espirito-Santo e Espirito-Santense. Segundo Gontijo e Gomes (ibidem), as tensões entre os redatores desses jornais estavam relacionadas às questões de métodos de leitura. O jornal A Província do Espirito-Santo defendia a vinda de Silva Jardim, bem como sua didática, porque seus proprietários eram partidários do método intuitivo para o ensino. Porém, o jornal Espirito-Santense

[...] publicou um editorial com o título Coisas do Sr. Inglês, criticando, entre outras iniciativas do Presidente da Província, o fato de estar fazendo gastos excessivos com a divulgação do Método 
João de Deus que já era conhecido na Província, antes mesmo da vinda de Silva Jardim. (ibidem, p.122)

Depois de atuar na província do Espírito Santo, de volta a São Paulo, em outubro de 1882, Silva Jardim inscreveu-se no concurso para o provimento da Cadeira de "Grammatica e Lingua Nacional" da ENSP. Nesse concurso, também se inscreveram Manoel José Trancoso e Júlio Ribeiro ${ }^{21}$ (D’Ávila, 1946, p.91). As inscrições encerraram-se em março de 1883, e, após a realização das provas, nesse mesmo ano, Silva Jardim foi aprovado no dia 26 de abril de 1884 e nomeado professor vitalício da Cadeira de "Gramática e Língua Nacional” da ENSP. Segundo Queiroz (1967), além de seu trabalho como professor, Silva Jardim ministrava aulas particulares.

No mesmo ano de seu ingresso como professor na ENSP, em 1응 de maio de 1883, Silva Jardim casou-se com Ana Margarida Bueno de Andrada, e, após nove meses de casado, nasceu seu primeiro filho, cujo nome também era Antonio da Silva Jardim. Silva Jardim teve outros dois, Condorcet e Clotilde Sofia, que morreram precocemente. Segundo Fernandes (2008, p.71), “[...] a valorização pela família, a admiração pelo jacobinismo a la Danton e à filosofia de Condorcet, bem como a filiação ao Positivismo estão expressos nos três filhos".

No dia 21 de abril de 1884, em cumprimento ao Artigo 8 do Regulamento de 1880... ENSP, Silva Jardim proferiu a Conferência Reforma do ensino da língua materna à congregação dessa instituição

21 Manoel José da Lapa Trancoso nasceu na província do Rio de Janeiro e faleceu no dia 17 de abril de 1894, tendo sido bacharel em Direito pela Faculdade de São Paulo. Nessa instituição, ministrou aulas de Filosofia e de Retórica. Também ministrou aulas de História do Brasil no curso anexo da Faculdade de Direito de São Paulo (Blake, 1900, p.136). Júlio César Ribeiro Vaugham nasceu no dia 16 de abril de 1845, em Sabará (MG) e faleceu no dia 1ํo de novembro de 1890, em Santos (SP). Foi professor na Escola Normal de São Paulo e ocupou a Cadeira de Latim no curso anexo da Faculdade de Direito. Além disso, teve publicados o livro Grammatica portugueza (1881) (Rocco, 1946) e livros de literatura, como A carne (1884), entre outros. 
de ensino. A versão escrita do resumo dessa conferência foi publicada em formato de opúsculo (Jardim, 1884) e divulgada aos alunos da ENSP como um modelo para o ensino da leitura.

Concomitante à atuação como professor da ENSP, Silva Jardim foi diretor da Escola Neutralidade, ${ }^{22}$ na cidade de Santos, na província de São Paulo. Essa escola foi fundada por Silva Jardim, com o professor João Köpke, ${ }^{23}$ no ano de 1884 . Com a fundação dessa instituição de ensino, Silva Jardim

[...] pretendia livremente pôr em prática os seus métodos pedagógicos e desenvolvê-los. Perturbadora novidade para época, a escola era laica. Seu nome, a Escola Neutralidade, tencionava indicar justamente este caráter "neutro" em face da religião. (Queiroz, 1967, p.52)

O ano seguinte, 1885, foi bem conturbado para Silva Jardim. Embora convicto de seus ideais republicanos, durante as eleições da província de São Paulo daquele ano, optou por defender o monarquista e conselheiro Martim Francisco de Andrada, que era seu sogro. Tal fato foi assim justificado por Silva Jardim:

[...] quando voto, voto no partido que mais me parece estar approximado das minhas idéas, desde que se compromete a pugnar por um certo numero de medidas, que julgo necessárias á minha Patria. (Leão, 1895, p.83)

Ainda no ano de 1885, "[...] após a morte de seu sogro, de sua filhinha Clotilde (recém-nascida) e de seu cunhado” (Guzzo, 2003,

22 A Escola Neutralidade era destinada a crianças e a adolescentes de 7 e 18 anos, e seu ensino era pautado no método intuitivo e concreto. A esse respeito, ver, especialmente, Hilsdorf (1986).

23 Informações sobre João Köpke encontram-se em texto de Maria do Rosário Longo Mortatti que integra este livro. Estudo minucioso sobre esse autor foi desenvolvido por Magnani (1997), Mortatti (2000; 2002) e Ribeiro (2001), também no âmbito do GPHELLB. 
p.16), Silva Jardim pediu licença de suas atividades na ENSP e foi para a cidade de Santos,

[...] onde se hospedou na casa de seu velho protetor e amigo Inglês de Sousa. Na cidade portuária advogava e residia, também, outro cunhado seu, o Dr. Martim Francisco Júnior, homem culto, inteligente da cidade e percebendo boas perspectivas, Silva Jardim resolver ficar. Pediu demissão da Escola Normal de São Paulo e montou um estabelecimento de ensino particular primário e secundário, ao qual, a princípio se dedicou de corpo e alma. (Queiroz, 1967, p.54)

A escola “José Bonifácio” foi fundada por Silva Jardim, em Santos, que nela atuou como diretor e professor. No ano de sua fundação," [...] contava com 57 alumnos, incluindo 30 de um professor do logar a quem chamára a si e dava bom ordenado e achava-se satisfeito com a prosperidade do estabelecimento" (Leão, 1895, p.129).

No período em que permaneceu na cidade de Santos, Silva Jardim “[...] conviveu com advogados, intelectuais descontentes, pequenos comerciantes irritados, estivadores e libertos, visitando os quilombos, refúgio e cidadela dos negros da Província” (Lima, 1987 , p.59). Contudo, nesse período, deixou o cargo de diretor e sócio da Escola Neutralidade e, no ano seguinte, em 1887, filiou-se ao Clube Republicano ${ }^{24}$ de Santos, que era conhecido pela sua marca política de esquerda (Fernandes, 2008). A partir da adesão a esse clube, iniciou suas conferências sobre o abolicionismo e as possibilidades de uma República brasileira, uma vez que foi militante e combatente contra a escravidão e lutou em sociedades secretas que libertavam escravos negros (Queiroz, 1967; Guzzo, 2003).

A partir de sua participação no Clube Republicano de Santos, Silva Jardim, aos 27 anos de idade,

24 O Clube Republicano de Santos era marcado por uma política abolicionista $e^{\text {" }}[\ldots]$ que nunca abandonou a causa da libertação dos escravos às suas ideias progressistas” (Guzzo, 2003, p.16). 
[...] penetrou, sùbitamente, no limiar de uma fase inteiramente nova de sua vida. Até ali - era assim que sentia - tinha andado às apalpadelas, como quem nunca vira de cheio a luz do mundo. Encontrava agora a sua determinação, o seu caminho, a sua existência construtiva. E após sua entrada decisiva na política nacional, ao discursar no comício de protesto contra o Terceiro Reinado e de apoio à atitude rebelde da Câmara de São Borja partiria pelo Brasil afora, na sua longa viagem de agitador e propagandista da República - homem de luta populares, enérgico e consciente como poucos tivera até então a nossa Pátria. (Queiroz, 1967, p.56)

Os anos de 1888 e 1889 foram marcados por um período de efervescência política na vida de Silva Jardim. Nessa época, passou a desempenhar o papel de propagandista da República, propriamente brasileira. Lima (1987, p.52) afirma que, nesse período,

[...] Silva Jardim fazia um julgamento contundente e abrangente de toda a instituição monárquica, de modo a ressaltar, perante a população, os seus defeitos e insuficiências, contrapondo-lhe a República $[. .$.$] instituição estabelecida dentro dos princípios do$ positivismo, de ordem e progresso.

Durante sua trajetória como propagandista da República, Silva Jardim visitou várias cidades das províncias de Minas Gerais, Rio de Janeiro, São Paulo, Pernambuco, Bahia e Rio Grande do Sul, a fim de apresentar as vantagens desse regime político. Em seus discursos e debates, Silva Jardim conquistou muitas amizades, mas também fez inimigos que ameaçaram sua integridade física. Todas as despesas com essas viagens eram pagas com tributos próprios, o que mostrava seu anseio e determinação a favor da abolição e da queda da Monarquia (Leão, 1895).

Após a Proclamação da República, em 15 de novembro de 1889 , em uma de suas viagens à Itália, Silva Jardim caiu em uma das crateras do vulcão Vesúvio e morreu, em 1o de julho de 1891. Sua 
morte representou, segundo muitos estudiosos, "[...] a morte de um republicano e o nascimento da República” (ibidem, p.290).

Aos seus adversarios, os que assim concorreram, para seu exílio voluntario e morte súbita, si bem que imprevista, ficou sempre desimpedido o caminho dos traves que as pessoas honestas opoem aos desmandos políticos e, envolta com essas vantagens na fruição dos gozos públicos, o remorso das consciências traiçoeiras e ambiciosas. (ibidem, p.290)

\section{Bibliografia de Antonio da Silva Jardim ${ }^{25}$}

A produção de Silva Jardim está centrada em publicações contra o regime monárquico e em defesa da instauração do regime republicano no Brasil, tais como folhetos, livros, artigos em jornais, discursos e conferências, nos quais ele tematizava seus anseios republicanos.

Setenta por cento de sua produção escrita resulta de suas conferências, discursos, artigos de jornais, manifestos, circulares, fo-

25 No Instrumento de Pesquisa Bibliografia de e sobre Antonio da Silva Jardim: um instrumento de pesquisa (Pasquim, 2012) reuni 139 referências de textos de outros autores sobre Silva Jardim e de textos que contêm menções a Silva Jardim, sua atuação profissional e produção escrita, e/ou citações de seus textos. Essas referências estão ordenadas em duas seções: "Bibliografia de Antonio da Silva Jardim", e "Bibliografia sobre Antonio da Silva Jardim". Na primeira seção "Bibliografia de Antonio da Silva Jardim”, encontram-se 45 referências de textos de Silva Jardim, subdivididas em onze subseções, conforme os tipos de textos que localizei. Os títulos das subseções e a quantidade de referências correspondentes a cada uma delas são as seguintes: obras, nove; obras em coautoria, duas; obras póstumas, duas; opúsculo, um; artigos em jornais, dez; circulares, duas; manifestos, um; conferências, cinco; discursos, nove; relatório em coautoria, um; e correspondência, uma. Dentre os textos sobre Silva Jardim, destaco o livro Propaganda republicana (1888-1889): discursos, opúsculos, manifestos e artigos coligidos, anotados e prefaciados por Barbosa Lima Sobrinho, publicado em 1978 pela Fundação Casa de Rui Barbosa e Conselho Federal de Cultura (RJ). 
lhetos e livros, publicados entre 1888 e 1889, durante seu itinerário propagandista pelas províncias brasileiras.

Devido ao interesse que demonstrava pelas conferências do Centro Republicano e entusiasmado pelo clima de época, Silva Jardim escreveu o artigo intitulado "Tiradentes", que foi publicado em uma das edições do jornal Labarum Literário. Segundo Lima (1987, p.40), Silva Jardim distinguia-se "[...] entre os colegas, encontrando tempo ainda para dedicar-se à literatura, colaborando no Labarum Literário, jornalzinho feito pelos próprios alunos, chegando a ser redator-chefe".

Em 1878, em coautoria com Valentim Magalhães, Silva Jardim teve publicada a obra Ideias de moço, na qual defendem o ideal da República. Em 1889, também em coautoria com Valentin Magalhães, teve publicado o artigo "General Osório", no jornal Tribuna Liberal.

Em 1879, Silva Jardim teve publicada a obra A gente no mosteiro, pelo jornal Tribuna Liberal (SP). Segundo Queiroz (1967), Lima (1987) e Dornas Filho (1936), em uma reunião entre calouros e veteranos da Faculdade de Direito, Silva Jardim, recém-ingresso nessa instituição, pediu a palavra em um momento não oportuno. Tal atitude foi criticada pelos veteranos. Com relação a esse episódio, na obra Gente no mosteiro, Silva Jardim “[...] acusa os colegas de serem autoritários e elitistas, questionando, inclusive, a capacidade de ser, choveram críticas em todos os jornais dos estudantes, e também nos muros" (Fernandes, 2008, p.73).

Em 1880 foi publicada a obra Critica escada abaixo, em que, segundo Fernandes (ibidem, p.73), Silva Jardim "[...] busca enveredar pelo caminho da crítica literária, debatendo a visão que Camilo Castelo Branco possuía do Brasil, acusando-o de destilar ódio ao país".

Em 1884 foi publicado o opúsculo Reforma do ensino da lingua materna, pela tipografia Jorge Seckler (SP). ${ }^{26}$ Trata-se da Conferência pública proferida por Silva Jardim, professor da 1aㅡ Cadeira

26 Análise detalhada dessa conferência encontra-se em Pasquim (2013). 
de "Lingua Portugueza" da ENSP. Nessa conferência, ocorrida no dia 21 de abril de 1884, perante a Congregação da Escola Normal, incluindo alunos e professores, Silva Jardim tematiza o ensino da leitura, tema relevante e pertinente no contexto da época, como mencionei.

Nessa conferência, Silva Jardim esclarece que os direitos de publicação pertenciam à Bibliotheca da Escola Normal, "[...] em favor da qual desiste o autor dos direitos pátrios de propriedade litteraria, para que seja gratuitamente distribuido pelos alumnos da Escola, pelos professores públicos, autoridades escolares, e mais pessoas interessadas no ensino, em geral." (Jardim, 1884, p.7). Apresenta, também, dedicatórias aos seus familiares, aos professores e alunos da ENSP e aos ex-alunos da aula anexa. E, em apêndice, têm-se os seguintes documentos: Programma para o ensino da Lingua Materna nas escolas primarias annexas á Escola Normal (1884); Resumo dos PROGRAMMAS adoptados pela Congregação da Escola Normal para o curso de Grammatica e Língua Nacional no anno de 1884; Programma do Curso da 1a Cadeira da Escola Normal segundo a proposta de REFORMA DO REGULAMENTO authorisada pela lei n. da Assembléa Provincial e apresentada ao Exm. Governo.

Nessa conferência, Silva Jardim defende a eficácia do "método João Deus", por meio da utilização da Cartilha maternal ou arte da leitura, escrita pelo poeta, pedagogo e republicano João de Deus (1830-1896) e publicada, em 1876, em Portugal. Silva Jardim considerava esse método mais apropriado para ensinar a língua materna às crianças, porque estava centrado no método da palavração e consistia em iniciar o ensino da leitura pela palavra, para depois analisá-la a partir dos valores fonéticos das letras (Mortatti, 2000). Esse método vinha contrapor-se aos métodos da soletração e da silabação, ambos de uso rotineiro naquela época.

Segundo Mortatti (ibidem), o "método João de Deus" para o ensino inicial da leitura divulgado nessa cartilha começou a circular também, mais sistematicamente, no Brasil, a partir dos anos iniciais da década de 1880, principalmente nas províncias de São Paulo e 
do Espírito Santo. Esse movimento de propagação e utilização do "método João de Deus" estava em sintonia com as ideias e os modelos pedagógicos em vigência, nesse mesmo momento histórico, em Portugal e no Brasil.

Ainda em 1884, juntamente com o professor João Köpke, Silva Jardim escreveu um relatório sobre a Escola Primária de Neutralidade, no qual apresentou alguns resultados do funcionamento dessa escola. Esse relatório foi publicado em 1885, pela Leroy King Bookwalter (SP).

Entre 1888 e 1889, período no qual Silva Jardim dedicou-se quase exclusivamente à propaganda republicana, teve publicadas as seguintes obras: A republica no Brazil: compendio de theorias e apreciações políticas destinado a propaganda republicana... (1888); A republica no Brazil (1889); Pela republica e contra a monarquia: conferencias populares (1889); Carta política ao país e ao partido republicano (1889); e Pela republica e contra a monarquia: conferencias populares (1889).

Ainda nesse período (1888-1889), Silva Jardim teve publicados muitos artigos em jornais, discursos, manifestos, circulares e conferências, nos quais mostrava-se declaradamente contra a Monarquia e a favor do abolicionismo, do positivismo e da instalação da República. Tal fato pode ser observado nos títulos dos textos: "A caminho", "A conspiração", "A mentira do trono", "A propaganda republicana”, "A situação republicana”, "Carta política ao País” e ao "Partido Republicano", "Política Republicana" e "Manifesto à Província e ao País”.

Em 1891, foi publicada a obra póstuma Memórias e viagens I Campanha de um propagandista (1887-1890), pela editora Typ. Comp. Nacional (Lisboa, Portugal). Segundo Fernandes (2008, p.75), esse livro é "[...] composto de longas transcrições de discursos ou artigos anteriores, mas recheados de reflexões do propagandista decepcionado com os rumos da jovem república e de justificativas do autor para uma série de posturas adotadas em sua vida”.

Em 1978, foi publicado, pela Fundação Casa de Rui Barbosa e Conselho Federal de Cultura, o livro Propaganda Republicana 
(1888-1889): discursos, opúsculos, manifestos e artigos coligidos, anotados e prefaciados por Barbosa Lima Sobrinho, que destaca que:

[...] a leitura de seus discursos e opúsculos permitirá acompanhar a evolução de suas ideias, num sentido que se poderá classificar de revolucionário, dissociado de tantos cursos e opúsculos permitirá acompanhar a evolução de suas ideias, para a conquista do poder. Isso é o que caracteriza a posição singular de Silva Jardim: é que visava, acima de tudo, a formação de uma opinião republicana, como conquista preliminar do advento de um regime, que lhe parecia falso, se não correspondesse a raízes profundamente mergulhadas no espírito do povo brasileiro. (Lima Sobrinho, 1987, p.14)

Esse livro muito contribuiu para que estudiosos e pesquisadores conhecessem o pensamento e ação política de Silva Jardim, uma vez que nele está disponível a maioria dos textos de sua autoria, escritos nos dois anos que antecederam a instauração da República no Brasil, ou seja, no período em que ele atuou sistematicamente como propagandista desse regime político.

\section{Bibliografia sobre Antonio da Silva Jardim}

No que se refere à produção escrita sobre Antonio da Silva Jardim, reuni 139 referências de textos de outros autores sobre Silva Jardim e textos que contêm menções a Silva Jardim, sua atuação profissional e produção escrita e/ou citações de seus textos (Pasquim, 2012).

Em relação aos textos sobre Antonio de Silva Jardim, ou seja, que tratam especificamente desse autor, reuni 37 referências de texto, que estão assim ordenadas: livros, dezessete; artigos, seis; capítulos, três; trabalhos acadêmicos, quatro; artigos de jornais, três; textos completos publicados em anais de eventos, três; e verbete de dicionário, um. 
Em relação aos textos que contêm apenas menções a Silva Jardim, sua atuação profissional e sua produção escrita e/ou textos que contêm citações de seus textos, reuni 57 referências de texto, que estão assim ordenadas: menções e/ou citações em livros, dezoito; menções e/ou citações em artigos, dezesseis; menções e/ou citações em trabalhos acadêmicos, dez; menções e/ou citações em textos completos em anais de eventos, onze; menções e/ou citações em verbete de dicionário, um; legislação municipal, uma.

Os textos que contêm apenas menções a Silva Jardim, sua atuação profissional e sua produção escrita e/ou textos que contêm citações de seus textos foram publicados entre 1889 e 2011, ou seja, ao longo de 122 anos. Porém, somente a partir de 1996 é possível verificar a regularidade nas publicações sobre Silva Jardim.

Ainda nesse período, entre 1889 e 2011, há intervalos consideráveis, sem publicação de textos sobre Silva Jardim e/ou textos que mencionam e citam seus textos. São eles: 1890, 1892, 1893 e entre 1896 e 1908. É possível observar que, a partir de 1896, há um intervalo de doze anos sem publicações de textos sobre Silva Jardim e/ ou que mencionam e citam seus textos.

Entre as 36 referências de textos sobre Silva Jardim, dezessete são de livros que tratam de biografias e memórias sobre a vida e obra de Silva Jardim, nos quais se pode observar um destaque para sua atuação como adepto do positivismo e defensor do regime político republicano.

Entre as 56 referências de textos que contêm apenas menções a Silva Jardim, sua atuação profissional e sua produção escrita e/ou seus textos, pode-se observar que, a partir das três últimas décadas, os estudos sobre a atuação de Silva Jardim estão relacionados com a história da educação, em particular, com história da alfabetização no Brasil. Nesse campo, a partir da divulgação dos resultados das pesquisas de Magnani (1997) e Mortatti (2000), o interesse tem recaído, especialmente, na atuação de Silva Jardim como defensor e divulgador do "método João de Deus" contido na Cartilha maternal ou arte da leitura (1876), escrita pelo poeta português João de Deus, também positivista e republicano. 


\section{Considerações finais}

Em relação à apresentação dos aspectos sobre a vida, formação e atuação do professor Silva Jardim, é possível destacar que a produção sobre ele está diretamente relacionada a conceitos-chave, tais como abolicionismo, republicanismo, positivismo e cientificismo. Estes operam de diferentes modos em seu pensamento e são representativos de sua ação e atuação política. Por serem os conceitos mais explorados de seu pensamento, por muito tempo destacou-se sua atuação como "herói da República", lugar de prestígio que ocupa nos estudos sobre a história do Brasil Império.

No entanto, como se pode constatar, a educação é uma face menos explorada do pensamento e da atuação de Silva Jardim, o que não significa que seja menor, posto que ele pensava a alfabetização e a educação de um ponto de vista político e parte integrante de seu projeto republicano, ou seja, para a formação de uma nação.

Estudos pontuais, como o que apresento neste texto, podem contribuir para a compreensão de aspectos ainda pouco explorados no âmbito da história da alfabetização e principalmente para a abertura de outras possibilidades de pesquisa.

\section{Referências bibliográficas}

AGUIAR, L. Antonio da Silva Jardim: o herói da Proclamação da República. Rio de Janeiro: Ao livro técnico, 1989.

BEHAR, E. Vultos do Brasil: bibliografia, história e geografia. São Paulo: Hemus, [s.d].

BEZERRA, C. E. de O. Adolfo Caminha: um polígrafo na literatura brasileira do século XIX (1885-1897). São Paulo: Cultura Acadêmica, 2009. BLAKE, A. V. A. S. Diccionario bibliographico brazileiro. Rio de Janeiro: Imprensa Nacional, 1900.

BOSI, A. Dialética da colonização. São Paulo: Companhia das Letras,1996. BOTO, C. J. M. C. dos R. Ler, escrever, contar e se comportar: a escola primária como rito do século XIX português (1820-1910). São Paulo, 1997. Tese (Doutorado em História Social) - Faculdade de Filosofia, 
Letras e Ciências Humanas, Universidade de São Paulo. Disponível em: <http://www.teses.usp.br/teses/disponiveis/8/8138/tde20032012-103942/>. Acesso em: 30 ago. 2012.

BRAGA, T. João de Deus: esforço biographico. [S.1.], Arthur Brandão, [s.d].

CARVAlHO, W. A. de. Pequena história da Maçonaria no Brasil. Revista dos Estudos Históricos da Masonería LatinoAmericana y Caribenã, [s.1.], v.2, n.1, mayo-noviembre 2010. p.32-58. Disponível em: $<$ http://dialnet.unirioja.es/servlet/articulo? codigo=3268641>. Acesso em: 25 jan. 2013.

CRUZ, H. de F. São Paulo em papel e tinta: periodismo da vida urbana (1890-1915). São Paulo: Educ: Fapesp; Arquivo do Estado de São Paulo; Imprensa Oficial, 2000.

D'ÁVILA, A. Antônio da Silva Jardim. In: POLIANTEIA comemorativa do 1o centenário do Ensino Normal de São Paulo, São Paulo, [s.n.], 1946, p. 89-98.

DORNAS FILHO, J. Silva Jardim. São Paulo: Editora Nacional, 1936.

ENCYCLOPÉDIE de L'Agora. Charles Augustin Sainte-Beuve. Disponível em: <http://agora.qc.ca/dossiers/Charles-Augustin_Sainte-Beuve>. Acesso em: 24 jan. 2013.

FACULDADE DE DIREITO DE SÃO PAULO. Galeria de Diretores. Vicente Mamede de Freitas (1904-1908). Disponível em: <http:// www.direito.usp.br/faculdade/diretores/index_faculdade_diretor_11.php>. Acesso em: 25 jan. 2013.

FERNANDES, M. F. L. A esperança e o desencanto: Silva Jardim e a República. São Paulo: Humanitas; Fapesp, 2008.

GONTIJO, C. M. M.; SCHWARTZ, C. M. Estudos sobre história da alfabetização e do ensino da leitura no Espírito Santo. In: MORTATTI, M. do R. Alfabetização no Brasil: uma história de sua história. São Paulo: Cultura Acadêmica; Marília: Oficina Universitária, 2011, p. 201-20.

; GOMES, S. C. Escola primária e ensino da leitura e da escrita (alfabetização) no Espírito Santo (1870 a 1930). Vitória, 2012. (no prelo).

GRISI, R. O ensino da leitura: o método e a cartilha. São Paulo: Imprensa Oficial do Estado, 1946. (Separata da revista Educação).

GUZZO, M. A. D. Silva Jardim: política, economia, questão social, abolicionismo e racismo. São Paulo: Ícone, 2003. 
HISLDORF, M. L. S. Francisco Rangel Pestana: jornalista, político, educador. São Paulo, 1986. 343f. Tese (Doutorado em Educação) - Faculdade de Educação, Universidade de São Paulo.

JAPIASSÚ, H.; MARCONDES, D. Dicionário básico de Filosofia. 5.ed. Rio de Janeiro: Zahar, 2008.

JARDIM, A. da S. Relatorio apresentado a S.Ex. o Sr. Presidente da província do Espirito-Santo Dr. H.M. Inglez de Sousa sobre a historia e resultado da propaganda do methodo de leitura João de Deus. Vitoria: Typ. da Provincia, 1882.

. Reforma do ensino da língua materna. São Paulo: typ. Seckler, 1884. (Conferência realizada no dia 22 de abril de 1884 na Escola Normal de São Paulo).

JORNAL A CONSTITUINTE, São Paulo, anno 3, 1879.

LAROUSSE. Encyclopédie. Hippolyte Adolphe Taine. Disponível em: $<$ http://www.larousse.fr/encyclopedie/litterature/Taine/177280>. Acesso em: 24 jan. 2013.

LEÃO, J. Silva Jardim: apontamentos para a biographia do illustre propagandista, hauridos nas informações paternas e dados particulares e officiaes. Rio de Janeiro: Imprensa Nacional, 1895.

LEITE, A. R. de P. Silva Jardim: o esquecido. São Paulo: Impr. Pannartz, 1984.

LIMA, H. F. Perfil político de Silva Jardim. São Paulo: Editora Nacional; Brasília: INL, 1987.

LIMA SOBRINHO, B.. Silva Jardim: discursos, opúsculos, manifestos. Niterói: Imprensa Universitária. 1973.

MACHADO, J. T. M. L. Co. Boletim da Sociedade de Geografia de Lisboa. Separata, Lisboa, 1981.

MAGNANI, M. do R. M. Os sentidos da alfabetização: a "questão dos métodos" e a constituição de um objeto de estudo (São Paulo: 1876/1994). Presidente Prudente, 1997. 389f. Tese (Livre-Docência em Metodologia do Ensino de 1ํㅡrau: Alfabetização) - Faculdade de Ciência e Tecnologia, Universidade Estadual Paulista.

MÓISES, M. História da literatura brasileira: realismo e simbolismo. Edição revista e atualizada. São Paulo: Cultrix, 2001.

MONTOYAMA, S. (org). USP 70 anos: imagens de uma história vivida. São Paulo: Editora da Universidade de São Paulo, 2006.

MORTATTI, M. do R. L. Os sentidos da alfabetização: São Paulo 1876/1994, São Paulo: Editora Unesp, 2000. 
João Köpke. In: FÁVERO, M. de L. de A.; BRITTO, J. de M. (orgs.). Dicionário de educadores no Brasil: da Colônia aos dias atuais. 2.ed. Rio de Janeiro: UFRJ; Brasília: MEC-Inep-Comped, 2002. . Educação e letramento. São Paulo: Editora Unesp, 2004. . (org.). Alfabetização no Brasil: uma história de sua história. São Paulo: Cultura Acadêmica; Marília: Oficina Universitária, 2011.

PASQUIM, F. R. Bibliografia de e sobre Antonio da Silva Jardim (18601891): um instrumento de pesquisa. 2012. (Digitado).

Reforma do ensino da língua materna (1884), de Antonio da Silva Jardim, na história do ensino de leitura e escrita no Brasil. Marília, 2013. 140f. Dissertação (Mestrado em Educação) - Faculdade de Filosofia e Ciências, Universidade Estadual Paulista.

PESTANA, M. G. Colecionando livros, formando mestres: a biblioteca pedagógica da Escola Normal de São Paulo (1883). São Paulo, 2011. 137p. Dissertação (Mestrado em Educação) - Pontifícia Universidade Católica de São Paulo, São Paulo.

POLIANTEIA comemorativa do 1ํㅡㄹ Centenário do Ensino Normal em São Paulo: 1846-1946. São Paulo: [s.n], 1946.

PORTUGAL. Dicionário histórico. Joaquim Teófilo Fernandes Braga. Disponível em: <http://www.arqnet.pt/dicionario/bragateofilo. html>. Acesso em: 24 jan. 2013.

QUEIROZ, M. V. de. Uma garganta e alguns niqueis: historia de Silva Jardim, o herói da propaganda republicana. Rio de Janeiro: Aurora, 1947. Paixão e morte de Silva Jardim. Rio de Janeiro: Civilização Brasileira, 1967.

REIS FILHO, C. A educação e a ilusão liberal. São Paulo: Cortez; Autores Associados, 1981.

REVISTA ILUSTRADA. Rio de Janeiro, anno 3, 1878. Publicada por Angelo Agostini. Disponível na seção "Obra Raras da Biblioteca Nacional" em: <www.bn.com.br>. Acesso em: 10 de janeiro de 2013. RIBEIRO, J. O que é positivismo. 7.ed. Brasiliense: 1988.

RIBEIRO, N. R. Um estudo sobre "A leitura analytica" (1896), de João Köpke. Marília, 2001. 66f. Trabalho de Conclusão de Curso (Graduação em Pedagogia) - Faculdade de Filosofia e Ciências, Universidade Estadual Paulista.

RICCI, M. L. de S. R. Ação e pensamento em Silva Jardim. Campinas: PUC, 1987.

ROCCO, S. (org.). Polianteia comemorativa do 1o centenário do Ensino Normal de São Paulo. São Paulo: 1846/1946. São Paulo: Gráfica Bréscia, 1946. 
SÃO PAULO. Regulamento da escola normal expedido aos 30 de junho de 1880 pelo conselheiro Laurindo Abelardo de Brito: autorizado pela disposição do Artigo 1ํ da lei no 130 de 25 de abril de 1880. São Paulo. VAINFAS, R. (org.). Dicionário do Brasil Imperial (1822-1889). Rio de Janeiro: Objetiva, 2008. 


\section{3 \\ JOÃo KöPKE (1852-1926) \\ NA HISTÓRIA DO ENSINO DE LEITURA \\ E ESCRITA NO BRASIL ${ }^{1}$}

Maria do Rosário Longo Mortatti

\section{Introdução}

Bacharel em Ciências Sociais e Jurídicas, João Köpke (18521926) destacou-se, ao longo de aproximados cinquenta anos, por sua atuação como educador, sempre marcada pelo espírito "bravo e rectilíneo" (D’Ávila, 1943, p.163), pela coerência e inflexibilidade de princípios, pelo envolvimento com a causa republicana, pelo pioneirismo na divulgação de modernas ideias e práticas pedagógicas e pela especial atenção dedicada à criança e ao ensino da leitura.

Teve atuação destacada na educação paulista e brasileira. Foi diretor de colégio e professor de várias matérias - em especial as do ensino primário - , escreveu cartilhas e livros de leitura, artigos para revistas e jornais e peças de teatro, traduziu textos pedagógicos e histórias infantis, e foi jornalista, polemista, crítico e conferencista.

Em especial no segundo momento da história da alfabetização no Brasil, João Köpke destacou-se na defesa do método analítico para o ensino da leitura, relacionado-o diretamente com as aspirações do regime republicano.

1 Artigo com conteúdo semelhante encontra-se em Mortatti (2002). 
Sua série de livros de leitura formou gerações de brasileiros ao longo de muitas décadas, e suas ideias inovadoras e pioneiras, especialmente sobre o ensino da leitura pelo método analítico - veiculadas em revistas e jornais e apresentadas de forma sistemática especialmente em duas cartilhas e duas conferências proferidas em São Paulo -, fizeram dele um precursor em relação a esse ensino, envolvendo-o também em acirradas polêmicas com os professores paulistas, especialmente nas décadas iniciais deste século (Mortatti, 2000)

Os princípios teóricos subjacentes ao modo de processar o método analítico que Köpke defendia para esse ensino são expostos, pela primeira vez de modo sistemático, na conferência "A leitura analytica", proferida em lo de março de 1896, na Escola Normal de São Paulo (ENSP). Os efeitos dessa conferência estenderam-se até as décadas iniciais do século XX, tendo culminado com acirradas polêmicas entre "modernos" e "mais modernos" (ibidem). É inegável, porém, tanto sua influência quanto o respeito obtido de educadores de sua geração e das seguintes.

O objetivo deste texto é, portanto, contribuir para a compreensão do lugar ocupado por João Köpke na história do ensino de leitura e escrita no Brasil.

\section{Aspectos da vida e da obra de João Köpke ${ }^{2}$}

\section{Dados biográficos}

João Köpke nasceu em 27 de novembro de 1852, em Petrópolis (RJ), e faleceu em 28 de julho de 1926, na cidade do Rio de Janeiro. Era filho de dona Felisbella Candida de Vasconcellos e do bacharel em Direito Henrique Köpke. De ascendência germânica, nascido

2 As informações contidas neste tópico foram extraídas de: Moscoso (1926); Amoroso Lima (1973); Meneses (1984); Mortatti (2000; 2001); e Ribeiro (2001). 
em Portugal, em 1807, e naturalizado brasileiro por volta de 1844, Henrique Köpke estabeleceu-se inicialmente em Sabará (MG) e depois passou a residir em Petrópolis, onde, com seu irmão, Guilherme Köpke, fundou o Collegio de Petropolis, inaugurado a 1ํ de janeiro de 1850 e consagrado com o nome de Colégio Köpke.

João Köpke recebeu formação primária no colégio fundado por seu pai e seu tio, e formação secundária no Colégio São Pedro de Alcântara, na cidade do Rio de Janeiro. Iniciou seus estudos superiores na Faculdade de Direito de Recife (PE) e, em 1871, mudou-se para a capital paulista, dando continuidade a seus estudos na Faculdade de Direito de São Paulo. No clima de efervescência de novas ideias que encontrou na província, iniciou sua amizade com Francisco Rangel Pestana e Antonio da Silva Jardim, ${ }^{3}$ tornando-se republicano ativo e positivista. Ainda cursando o quarto ano nessa faculdade, casou-se com dona Maria Isabel de Lima e, para sustentar a família e prosseguir nos estudos, passou a ministrar lições particulares e a lecionar em cursos preparatórios. Bacharelou-se em Ciências Sociais e Jurídicas em 1875, sendo o primeiro petropolitano a diplomar-se em curso superior. Nesse mesmo ano, foi nomeado promotor público em Faxinal (SP) e depois removido para as comarcas paulistas de Jundiaí e Campinas e para a capital do estado.

Sua carreira na magistratura, no entanto, foi logo interrompida. Talvez em decorrência da fama de "talentoso mestre de reconhecida cultura” (Meneses, 1984, p.30), que foi adquirindo nessas primeiras atividades como professor, e de seu envolvimento com a causa republicana, de acordo com a qual a instrução pública era considerada a mola propulsora do progresso social e material, em 1878, João Köpke passou a dedicar-se definitivamente ao magistério, iniciando uma intensa, inquieta e coerente atuação como educador, em São Paulo e no Rio de Janeiro.

3 Estudo sobre Antonio da Silva Jardim encontra-se em texto de Franciele Ruiz Pasquim, que integra este livro. Estudo minucioso sobre esse autor e sua obra encontra-se em Pasquim (2013). 
Na cidade de São Paulo, além de ministrar lições particulares, lecionou Inglês, Francês, Italiano e Geografia no Colégio Rangel Pestana, destinado a meninas e fundado em 1876 por Francisco e Damiana Rangel Pestana. Nessa época, foi nomeado, por decreto do governo da província, professor substituto de Filosofia, História, Geografia e Retórica no curso preparatório anexo à Faculdade de Direito, cargo do qual logo se demitiu, "[...] indisposto com o tráfico de influências para proteger e assegurar a aprovação dos apaniguados, no exame de admissão à Faculdade" (ibidem, p. 31).

Em 1880, João Köpke mudou-se para a cidade de Campinas, onde passou a lecionar no Collegio Culto á Sciencia - caracterizado pela adesão ao ideário republicano -, a convite do diretor Alfredo Campos da Paz, tornando-se o responsável pelo Gabinete de Física. Nessa cidade, João Köpke também ministrou lições particulares e lecionou no Colégio Florence, fundado, em 1863, pela educadora alemã Carolina Krug Florence e destinado à educação feminina. Apesar da "afanosa tarefa", atualizava-se constantemente com relação aos

[... progressos da pedagogia e à sua custa mandava vir da Europa aparelhos, mapas, quadros e coleção de objetos necessários ao ensino intuitivo. Em pouco tempo a sua sala se transformou em um pequeno museu pedagógico. Só ele na província possuía o que há de mais moderno para o ensino prático. (Rangel Pestana, 1906, p.795)

Tornou-se, então, "o mais apercebido mestre da província" (D’Ávila, 1943, p.162).

Em novembro de 1883, João Köpke foi nomeado, mediante aprovação em concurso, professor de História e Geografia no curso preparatório anexo à Faculdade de Direito de São Paulo. Em janeiro de 1884, retornou à cidade de São Paulo, onde fundou, com Antonio da Silva Jardim, a Escola Primária Neutralidade, cujo nome "já estava a indicar a orientação positivista, o descomprometimento com qualquer crença, o imparcialismo (ou a neutralidade) que deveria guiar os passos da ciência e do saber" (Meneses, 1984, p.32). 
Situada na Rua da Conceição e destinada a crianças e adolescentes de 7 a 18 anos, de ambos os sexos - algo digno de atenção para a época -, a escola contava, ainda, com professores como Francisco Rangel Pestana, Antonio Caetano de Campos, entre outros.

Em São Paulo, João Köpke permaneceu por pouco tempo. Em 1886, por “motivos íntimos” (Köpke, 1988, p.797), mudou-se definitivamente para a cidade do Rio de Janeiro, onde fundou o Instituto Henrique Köpke, assim denominado em homenagem a seu pai e no qual adotou o modelo de ensino da Escola Primária Neutralidade, de São Paulo. O Instituto começou a funcionar em fins de julho daquele ano, e Köpke passou por várias dificuldades financeiras.

Depois de ter cogitado desistir de tudo e acompanhar a educação de alguns antigos discípulos seus que iam estudar na Europa, cansado das dificuldades e contrariedades sofridas por querer exercer o magistério de maneira digna e honesta, Köpke conseguiu, por fim, superar os problemas financeiros e levar adiante as atividades do Instituto Henrique Köpke, com a ajuda do paulista Antonio de Souza Queiroz - em agradecimento ao que Köpke fizera por seus filhos -, bem como de Eduardo Guinle e Conrad Jacob Niemeyer, cujos filhos estudavam no Instituto.

Ainda em 1886, a atuação e capacidade profissional de Köpke para o magistério foram oficialmente reconhecidas mediante declaração do governo imperial, que o autorizava a ensinar matérias no ensino primário e secundário. Em dezembro desse ano, o educador fundou uma associação de professores no Rio de Janeiro, e "[...] no ano seguinte é designado para ocupar o cargo de membro substituto do Conselho da Instrução Primária e Secundária do Município da Corte" (Ribeiro, 1996, p.101-2). Sua atuação e sua autoridade como educador foram também reconhecidas quando, por ocasião da proclamação da República, seu nome fora cogitado, por membros do Partido Republicano Paulista, para dirigir a Escola Normal de São Paulo.

Situado na Rua Real Grandeza, no bairro de Botafogo, o Instituto Henrique Köpke ganhou fama e foi frequentado por meninos e meninas de famílias ilustres, como os filhos de Ruy Barbosa, do Barão Ribeiro de Almeida e os das famílias Guinle e Murtinho. Em 
1895, foi “[...] consagrado como escola padrão, por Decreto de Prudente de Moraes, equiparando-o ao Ginásio Nacional” (Meneses, 1984, p.35).

João Köpke permaneceu como diretor e professor do Instituto até 1897, quando se retirou da sociedade que o mantinha devido a divergências com sócios. Foi, então, nomeado, pelo presidente Campos Salles, oficial do registro geral e de hipotecas do Rio de Janeiro. Mesmo nesse cargo, continuou dedicando-se às atividades pedagógicas e educacionais, até sua morte, aos 74 anos.

Além de diretor de colégio e professor de várias matérias - com predileção pelas do ensino primário - , foi também autor de variada e profícua produção intelectual escrita relativa a temas e questões ligados à educação e ao ensino.

Como professor, "[...] sua principal marca pedagógica é a maneira de como tratar o aluno" (ibidem, 31), tendo exercido profunda influência sobre aqueles a quem ensinou e sendo lembrado especialmente por seu método de ensino, pelo encanto pela vida e pelo conhecimento que neles despertava.

Apesar dos ataques sofridos na defesa intransigente de suas ideias sobre ensino da leitura, elas continuaram a ser referência para muitos educadores de sua época e contaram sempre com calorosa recepção entre o professorado e as autoridades do estado de São Paulo, onde recebeu várias homenagens, entre as quais figura a de patrono da Cadeira n. 5 da Academia Paulista de Educação. Mas, sobretudo, João Köpke nunca deixou de se dedicar à sua preocupação com a educação da infância. Continuou revendo e atualizando sua obra didática, escreveu várias peças de teatro para crianças, em prosa e verso, a partir de histórias como Chapeuzinho Vermelho, Branca de Neve e A Bela Adormecida, e, em 8 de maio de 1924, em sessão extraordinária da Sociedade de Educação (SP), pronunciou a oração intitulada "Theatro juvenil". A partitura de peça A Bela Adormecida foi composta, gratuitamente, por um de seus antigos discípulos, doutor Carlos de Campos, que foi presidente do estado de São Paulo. A peça foi representada no Rio de Janeiro e em São Paulo, com grande sucesso (Moscoso,1926, p.6). 
Nos últimos anos de sua vida, além de pensar em "novo método de combater o analfabetismo através do rádio”, João Köpke ainda organizara "[...] na primeira estação de radiodifusão do Brasil - a Rádio Sociedade do Rio de Janeiro, do pioneiro Roquete Pinto - a 'Hora das Crianças', que redige [e apresenta] com o apelido de Vovô" (Campos, 1953, p.19).

Na tarde de 28 de julho de 1926, cercado de antigos discípulos, faleceu em sua casa no bairro de Laranjeiras, no Rio de Janeiro, logo após ter se calado o coro alegre das crianças que cantavam ali perto, no Colégio de Sion.

\section{A produção de e sobre João Köpke ${ }^{4}$}

O compromisso e a especial atenção que esse educador dispensou à criança e ao ensino da leitura pode ser constatada especialmente em sua produção escrita, por meio da qual exerceu grande influência na educação e no ensino em muitos estados brasileiros, especialmente São Paulo e Rio de Janeiro. Escreveu cartilhas e livros de leitura, peças de teatro e de programas de rádio e artigos em jornais e revistas, traduziu textos pedagógicos e histórias infantis, e foi conferencista, crítico e polemista.

Essa produção iniciou-se com Methodo racional e rapido para aprender a lêr sem solettrar - dedicado á infancia e ao povo brazilero (São Paulo: Garraux), que pode ser considerada obra da juventude,

4 Em Ribeiro (2001), encontra-se o instrumento de pesquisa, no qual foram reunidas e organizadas 39 referências bibliográficas de textos escritos por João Köpke, entre 1874 (ano de publicação de sua primeira cartilha) e 1945 (ano de republicação de artigo de sua autoria), e classificadas de acordo com os seguintes formatos de texto: livros, artigos, resenhas, conferências, cartilhas, livros de leitura e artigos didáticos. Foram também reunidas e organizadas, até 2001, 32 referências bibliográficas de textos sobre João Köpke, escritos entre os anos de 1850 e 2001, classificados como se segue: artigos de homenagens em periódicos, doze; referências e/ou comentários em livros, nove; em artigos e entrevistas, cinco; em teses, dissertações e similares; quatro. Além dessas 32 referências, têm-se quinze outras, sem data precisa, sobre o Collegio Köpke e a família Köpke. 
pois foi escrita quando Köpke tinha 22 anos. A 1a edição, datada de 1874, destinava-se aos alunos da Escola Americana de São Paulo. Em 1879, foi publicada sua 2a edição, para ser distribuída às escolas primárias, mediante autorização do governo (Moacyr, 1936, p.385). Nela, o autor baseava-se no método de silabação, o qual abandonaria duas décadas depois, em favor do método analítico para o ensino da leitura às crianças. ${ }^{5}$

Em 1884, João Köpke iniciou, com o Primeiro livro de leituras moraes e instructivas, a publicação da Série Rangel Pestana, composta por livros de leitura, relativos às seis partes do Curso systematico da lingua materna.

Publicados pela Livraria Francisco Alves (RJ), os livros dessa série tiveram sucessivas reedições, com revisões por parte do autor. Após sua morte, os livros foram "revistos pela professora Lúcia Monteiro Casassanta, reunidos na conhecida Coleção João Köpke até os anos 60, com títulos como 'Histórias de meninos na rua e na escola', 'Histórias que a mamãe contava' e outros” (Meneses, 1984, p.34).

Escreveu, ainda, outros livros para leitura na escola - como A grande patria, em comemoração ao quarto centenário do descobrimento do Brasil -, para o ensino de Inglês e Francês, e colaborou em jornais, como A Provincia de S. Paulo, O Estado de S. Paulo, Jornal do Commercio (RJ), e em revistas pedagógicas, como Eschola Publica e Revista de Ensino - órgão da Associação Beneficente do Professorado Público Paulista - e a Revista Pedagógica - órgão do Pedagogium, do Rio de Janeiro. Entre os artigos que escreveu, há vários de crítica a textos escolares, destacando-se a severa crítica, publicada na Revista de Ensino, referente ao livro Poesias infantis, de Olavo Bilac.

5 Estudos a respeito da utilização do método analítico no segundo momento da história da alfabetização encontram-se especialmente em Magnani (1997)/ Mortatti (2000), Ribeiro (2001), Bernardes (2003), Pereira (2009), Gazoli (2007), Sobral (2007), Oriani (2010), Pasquim (2010d), e nos textos de Vanessa Cuba Bernardes, Bárbara Cortela Pereira, Monalisa Renata Gazoli e Franciele Ruiz Pasquim que integram este livro. 


\section{A conferência "A leitura analytica"(1896) ${ }^{6}$ e a conferência "O ensino da leitura pelo método analítico" (1916)}

Em "A leitura analytica", conferência proferida em lo de março de 1896, em uma das salas da Escola Normal de São Paulo, a convite do Instituto Pedagógico de São Paulo, Köpke expôs a "doutrina relativa ao metodo analitico, aplicado segundo o processo, a que [sua] pratica [o] tinha levado" (Köpke, 1916, p.116).

As primeiras polêmicas foram veiculadas pela Revista de Ensino e diziam respeito a discordâncias de professores e escritores didáticos paulistas em relação ao método exposto por João Köpke nessa conferência. Köpke (1902) publicou, então, carta aos professores J. de Brito, R. Roca Dordal", em que, movido por "um dever de consciência profissional", contestou as críticas a respeito da impraticabilidade do processo analítico de leitura que aconselhava.

Ironicamente "embaraçado" com as infundadas objeções ao processo que indicava e praticava, "com os melhores resultados ha perto de trinta annos”, Köpke apresentou princípios teóricos e invocou a "didactica mais adeantada do mundo, a americana" (Köpke, 1902, p. 775), em defesa da aplicabilidade desse processo também no ensino simultâneo.

Quanto à crítica à suposta exigência de serem os professores "desenhistas notáveis", Köpke esclareceu que esta não era uma “condição necessária para o emprego do processo”, podendo-se recorrer a uma estampa, mediante o uso de clichês tipográficos ou de "chromos tão faceis de achar por estes tempos de cartazes reclamaticios e folhinhas de graça” (ibidem, p.774). Refutou, também, a acusação de usar e abusar da decoração, que julgava incompatível com o método analítico, de acordo com o qual a criança deve enten-

6 Estudo detalhado dessa conferência encontra-se em Ribeiro (2001).

7 Informações sobre Ramon Roca Dordal encontram-se em texto de Franciele Ruiz Pasquim que integra este livro. Estudos minuciosos sobre esse autor e sua obra foram desenvolvidos por Magnani (1997), Mortatti (2000) e Pasquim (2010c). 
der, em vez de decorar, como acontece quando se usa o método da soletração e suas abstrações, que "infernaram a aprendizagem de nossos antepassados, e levaram á affirmação brutal do 'la letra con sangre entra"' (ibidem, p.780). E enfatizava que se devem ensinar primeiramente a letra manuscrita e as minúsculas, para evitar duplicação desnecessária de esforços.

A fim de reafirmar "a base essencialmente pedagógica do processo de palavração”, Köpke invocou a obra The problem of teaching to read, de Meiklejohn, "apologia mais convencida e convincente da super-excellencia e archi-practibilidade desse processo de ensino, unico acceitavel para a iniciação da leitura em qualquer lingua do mundo" (ibidem, p.780) e fez uma demonstração prática de uma possível aplicação desse processo.

Das considerações e da "demonstração prática" sobressaem-se alguns princípios e conceitos que embasam o ponto de vista de Köpke. As sentenças formadas a partir da estampa devem ser curtas, para que todos seus elementos possam ser abarcados pela vista; a visão de todos esses elementos permite ler expressivamente, ou seja, relacioná-los na expressão do sentido; as "palavras concretas" devem preceder as "palavras abstractas ou de relação"; indutivamente, devem-se conduzir a comparação e a analogia entre forma fônica, já conhecida e depositária de sentido, e forma gráfica das ideias e, posteriormente, entre as formas gráficas. A escrita, portanto, equivale à "graphação" - "traçado consciente do signal" empregado como palavra, e não como letra - da ideia e representa a fala -, forma fônica da palavra, discriminada pelo ouvido; a leitura equivale à "emissão pela fala" da forma gráfica discriminada/reconhecida pela visão e representativa da forma fônica, o sentido conhecido; e aprender a ler equivale a um processo gradual de corporificação, na "intelligencia activa", do som com o sinal.

Vinte anos depois, Köpke complementou a primeira conferência com outra intitulada "O ensino da leitura pelo método analítico”, proferida nas dependências do Jardim da Infância, anexo à Escola Normal da Praça da República, em 11 de maio de 1916. Publicada em opúsculo para ser distribuída entre os professores e 
também em revistas, essa conferência tinha por objetivo explicar e divulgar as Cartilha n. 1 e Cartilha n. 2, escritas por Köpke depois de estudo constante e aprofundado dos princípios propagandeados na primeira conferência, como desobrigação da promessa do autor de "incorporar em livro o molde" que dava às lições "na aplicação do processo da leitura pelo metodo analitico” (Köpke, 1916, p.118), aproveitando a contribuição de "educacionistas" americanos e europeus, como Fröebel, Parker, Meiklejohn, Stanley Hall, Claubb, Carpenter, Jacotot e João de Deus.

Considerando-se um "veterano", nessa conferência de 1916 elogia os "novos" - os professores paulistas Theodoro de Moraes, Arnaldo de Oliveira Barreto e Carlos Antonio Gomes Cardim ${ }^{8}$-, que "filiam à propaganda do velho lidador a contribuição que trazem ao progresso de uma doutrina e pratica" (ibidem, p.119), e tece considerações a respeito das cartilhas desses professores paulistas, comparativamente às suas. Explicita também as diferenças entre suas cartilhas e duas publicações da Diretoria Geral da Instrução Pública de São Paulo: Instrucções praticas para o ensino da leitura pelo methodo analytico - modelo de lições (Oliveira, Dordal e Barreto, 1914) e Como ensinar leitura e linguagem nos diversos annos do curso preliminar (Carneiro et al., 1911). Na discussão dessas diferenças, abordou também a Cartilha de Arnold, escrita pela professora americana Sarah Louise Arnold e adaptada para o português em 1907.

Köpke ressaltou as bases psicológicas dos modernos "educacionistas" americanos e europeus, que propunham a instrução pelas coisas, e não mais pelas letras, e defendeu a idade média de 7 anos "termo da primeira infância" - como a ideal para se iniciar o ensino da leitura. Quanto ao método para ensinar a ler, há "uma preliminar obrigada: dado o mestre competente, tudo depende do discípu-

8 Informações sobre Theodoro de Moraes, Arnaldo de Oliveira Barreto e Carlos Alberto Gomes Cardim encontram-se em textos de Bárbara Cortella Pereira, Vanessa Cuba Bernardes e Franciele Ruiz Pasquim, respectivamente, que integram este livro. Estudos minuciosos sobre esses autores e sua obra foram desenvolvidos por Magnani (1997), Mortatti (2000), Pereira (2009), Bernardes (2003) e Pasquim (2010d). 
lo" (Köpke, 1916, p.120), ou seja, de suas aptidões, de onde decorre a escolha do método analítico e dos processos mais adequados para sua execução.

Sendo, porem, incontestavel que as crianças preferem as cousas completas, e acham, ao menos no vernaculo, como assevera Stanley Hall, as sentenças mais faceis que as palavras, como é certo que aborrecem os detalhes, os elementos e as abstrações, o ponto de partida para o ensino da leitura deve ser o TODO. Este TODO, mais do que a SENTENÇA, é a fala, a descrição, a narração, o DISCURSO, que a instruiu na lingua em que entende e se faz entendida, e que, sob a forma de conto ou historia escrita, se ha de traduzir a seus olhos, dando-lhe o segredo da representação grafica, em que entenda e se faça entendida.

Analitico, pois, será forçosamente o metodo desde que o TODO há de ser o ponto de partida, qualquer que seja o aprendiz; os processos, que todavia, puser em jogo, esses hão de combinar-se de modo a que olho, ouvido, boca e mão se exerçam conjuntamente em colaboração mutua para a conquista da perfeição automatica, mercê da qual a fala escrita se faz para a inteligencia, través da visão e da mão, o que para ela é a fala oral, através da audição e da boca. (idem, 1916, p.120)

Contrário às noções de leitura como transposição das letras em sons e baseado nas contribuições de Francis Parker, a respeito do estímulo que provoca a ação, e de Meiklejohn, a respeito da seriedade do brinquedo, Köpke apresentava o divertimento como finalidade da leitura e a necessidade de o professor procurar conhecer as fases particulares de seus alunos para organizar o ensino.

Advertia que o professor deve conhecer as fases particulares de seus alunos, a fim de organizar o ensino e os passos para despertar o interesse da criança. Esses passos iniciam-se com a leitura de pequenos entrechos iluminados por estampas e referentes ao "pensamento de outrem", devendo-se utilizar a história - e não frases ou palavras —, na qual o enredo, "a teia ininterrupta dos capítulos", 
garante o todo e a continuidade de sentido, visando-se, com isso, à formação do gosto estético e à leitura da "boa literatura".

Criticava, assim, a incoerência dos que, também se dizendo basear na necessidade de despertar o interesse, apresentavam à criança frases sem relação de sentido entre si - como o faz Arnold em sua cartilha - ou com nexo sintático apenas, como propõem as Instrucções práticas para o ensino da leitura pelo methodo analytico modelo de lições.

Por fim, Köpke destacava as dificuldades de adoção desse método, dadas tanto sua "lentidão" relativamente aos métodos sintéticos (soletração e silabação) quanto a exigência de professores mais bem preparados para utilizá-lo. Em contraposição às resistências impostas pelos defensores da "rotina pedagógica", apontava a falta de preparo para se receber tanto "a propria excellencia do methodo analytico", quanto a "própria excellencia do regimen político [republicano]” (ibidem, p.63).

Com as duas cartilhas, Köpke pretendia, mais uma vez, servir às crianças paulistas e brasileiras, para que pudessem contribuir para a consecução dos ideais republicanos e da afirmação da pátria brasileira. Na ocasião, tornou público o desejo de fazer doação dos direitos autorais das cartilhas ao estado de São Paulo, "como testemunho humilde, mas sincero, do [seu] ... reconhecimento ao estimulo e animação com que sempre amparou o [seu]... esforço modesto, porém devotado, obreiro na magna tarefa da nossa organização pedagógica" (ibidem, p.116). Dada essa oferta de direitos autorais, Oscar Thompson, então diretor-geral da Instrução Pública de São Paulo, designou os inspetores escolares B. Tolosa, G. Kuhlman e C. Couto para analisarem e emitirem parecer sobre a adoção da Cartilha n. le da $n$. 2. Com a conferência proferida por Köpke, em maio de 1916, e com a publicação desse parecer no jornal O Estado de S. Paulo, em 8 de outubro de 1916, tem-se acirrada polêmica sobre o método analítico, envolvendo os professores A. O. Barreto, C. A. G. Car$\operatorname{dim}$, T. Moraes e M. Oliveira, ${ }^{9}$ citados por Köpke na conferência.

9 Estudo sobre Mariano de Oliveira foi desenvolvido por Sobral (2007), no âmbito do GPHELLB. 
Em junho daquele ano, o jornal O Commercio de S. Paulo organizou um inquérito sobre o método analítico para o ensino da leitura, publicando entrevistas com os professores paulistas Barreto, Cardim e Moraes. E no dia 16 de outubro do mesmo ano, Köpke escreveu três cartas destinadas aos professores A. O. Barreto, C. A. Gomes Cardim e M. de Oliveira, as quais, em 1917, foram publicadas em conjunto sob o título $O$ methodo analytico no ensino da leitura.

Nessas entrevistas, conduzidas por M. B. Lourenço Filho, ${ }^{10}$ ressaltam-se o tom combativo das opiniões e a importância social atribuída ao método analítico. Nelas, os entrevistados expõem sua opinião sobre o "modo paulista de processar o methodo" e sobre o processo proposto por Köpke. Embora não desconsiderassem seu trabalho, nem deixassem de reconhecer seu mérito e a influência de suas ideias, esses professores paulistas consideravam desnecessário e mesmo prejudicial adotarem-se as cartilhas de Köpke e seu processo, uma vez que o modo de processar o "methodo analytico no ensino da leitura aos analphabetos" praticado nas escolas públicas paulistas era o ideal, respeitando as leis científicas do aprendizado da leitura e apresentando, então, resultados "verdadeiramente surprehendentes" (Barreto, 1916, p.1).

Nas cartas, mostrando-se magoado com as entrevistas e com a divulgação e publicização do parecer, cansado de polêmicas e desejoso de continuar a elaboração de livros didáticos, Köpke lamentou a não aceitação de suas cartilhas e manifestou sua indignação causada pelo tom de disputa em torno do método ideal para ensino da leitura, o qual os professores paulistas julgavam ter elaborado, desconsiderando, assim, tanto as cartilhas de Köpke quanto quaisquer outras iniciativas que se diferenciassem desse método ideal. Invocando as "verdades científicas" e a coerência lógica, Köpke opôs-se veementemente à proposta de adequação de suas cartilhas,

10 Informações sobre Manoel Bergström Lourenço Filho encontram-se em texto de Estela Natalina Mantovani Bertoletti que integra este livro. Estudos minuciosos sobre esse autor e sua obra foram desenvolvidos por Magnani (1997), Mortatti (2000) e Bertoletti (1997; 2006). 
defendeu-as como contribuição para o aprendizado da leitura de todos os brasileiros e lamentou, entre outros, os interesses pessoais e financeiros que sustentavam a polêmica. ${ }^{11}$

\section{Considerações finais}

Como se pode constatar, desde a conferência de 1896, João Köpke defendia contundentemente o método analítico e o modo de processuação por ele proposto, em oposição aos métodos sintéticos, os quais ele mesmo havia utilizado e defendido quando da publicação de sua primeira cartilha e os quais abandonou, convencido da excelência do método analítico e de sua adequação ao regime republicano então recém-implantado, de que decorreram significativas reformas na instrução pública paulista.

O processo defendido por João Köpke diferenciava-se também dos demais processos defendidos por seus contemporâneos, em especial por professores paulistas responsáveis pela institucionalização do método analítico no estado de São Paulo. ${ }^{12} \mathrm{~A}$ principal diferença entre eles consiste no fato de que Köpke: defendia a necessidade de se iniciar o processo de ensino pelo conto (discurso), e não pela "historieta", como propunham os paulistas; privilegiava a análise do conto, que, por sua vez, deveria ser escolhido, não com a preocupação em manter o enfoque no ensino das sílabas e letras, mas em apresentar, por meio de gravuras e palavras correspondentes, ideias familiares que deveriam favorecer a aprendizagem da leitura e escrita e conduzir conscientemente à abstração (elementos da palavra: sílabas e letras); e propunha que o ensino tivesse como objetivo a leitura inteligente e expressiva, a qual exige uma com-

11 Até o momento, não foi possível localizar exemplares de nenhuma das duas cartilhas de Köpke.

12 As propostas dos professores paulistas que atuaram no segundo momento da história da alfabetização no Brasil serão apresentadas em textos seguintes neste livro. 
preensão do leitor no ato de ler e impede que o ensino seja iniciado pela sentença ou conjunto delas, como propunham os professores paulistas.

João Köpke pode ser considerado um precursor em relação ao ensino inicial da leitura e escrita. Seu pensamento influenciou significativamente outros educadores de sua época e de décadas posteriores no que se refere às propostas e práticas de alfabetização.

Os princípios defendidos por João Köpke relacionam-se diretamente com o contexto educacional da época e com o regime republicano, cuja viabilização dependia, entre outros, da instrução do povo e da formação de leitores com certa moralidade, certa mentalidade, certo corpo de condutas compatíveis com a vida republicana. Mais que letrado, o "homem novo" deveria estar preparado para a nova sociedade científica, moderna e urbana, então em construção.

\section{Referências bibliográficas}

AMOROSO LIMA, A. Memórias improvisadas (diálogos com Medeiros Lima). Petrópolis: Vozes, 1973.

BERNARDES, V. C. Um estudo sobre Cartilha analytica, de Arnaldo de Oliveira Barreto (1969-1925). [S.1.]: [s.n], 2003.

CAMPOS, M. João Köpke e a educação. Revista do Professor, São Paulo, p.19, fev. 1953.

CARNEIRO, M. et al. Como ensinar leitura e linguagem nos diversos annos do curso preliminar. São Paulo: Siqueira, Nagel \& Comp, 1911.

D'ÁVILA, A. História da educação no Brasil - João Köpke. Revista de Educação, São Paulo, v.30, n.40-41, p.161-165, jul./dez. 1943.

GRISI, R. O ensino da leitura: o método e a cartilha. São Paulo: Imprensa Oficial do Estado, 1946. (Separata da revista Educação).

HARRIS, T. L.; HODGES, R. E. (orgs.) Dicionário de alfabetização. Tradução de Beatriz Végas-Faria. Porto Alegre: Artes Médicas Sul, 1999.

HILSDORFF, M. L. S. Francisco Rangel Pestana: jornalista, político, educador. São Paulo, 1986. 343f. Tese (Doutorado em Educação) Faculdade de Educação, Universidade de São Paulo.

KÖPKE, J. A leitura analytica (Conferência feita a 1ํ de março de 1896, no Instituto Pedagógico Paulista). São Paulo: Typ. a vapor de Hennies Irmãos, 1896. 35p. 
. Ensino da leitura (Carta aos professores J. de Brito e R. Roca Dordal). Revista de Ensino, n.4, p.772-793, out. 1902 (Seção "Crítica sobre trabalhos escolares").

O ensino da leitura pelo methodo analytico. Revista do Brasil, São Paulo, v.2, n.5, p.31-69, maio 1916.

O ensino da leitura pelo método analítico (Conferência realizada na Escola Normal da Praça da República, em 11 de maio de 1916). Educação, São Paulo, v. 33, n. 46/47, p.115-52, jan.-jun., 1945.

MAGNANI, M. do R. M. Os sentidos da alfabetização: a "questão dos métodos" e a constituição de um objeto de estudo (São Paulo: 1876/1994). Presidente Prudente, 1997. 389f. Tese (Livre-Docência em Metodologia do Ensino de 1ํㅡrau: Alfabetização) - Faculdade de Ciência e Tecnologia, Universidade Estadual Paulista.

MENESES, J. G. de C. Discurso de posse do acadêmico titular João Gualberto de Carvalho Meneses. Boletim da Academia Paulista de Educação, São Paulo, n.9, p.26-38, jan.-jul. 1984.

METHODO de ensino. Revista de Ensino, São Paulo, v.5, n.3, p.25-8, dez. 1911.

MORTATTI, M. do R. L. Os sentidos da alfabetização (São Paulo 1876/1994). São Paulo: Editora Unesp; Brasília: MEC/Inep/Comped, 2000.

João Köpke. In: FÁVERO, M. de L. de A; BRITTO, J. de M. (orgs.). Dicionário de educadores no Brasil: da Colônia aos dias atuais. 2.ed. Rio de Janeiro: UFRJ; Brasília: MEC-Inep-Comped, 2002.

MOSCOSO, T. Professor João Köpke. Boletim da Associação Brasileira de Educação, Rio de Janeiro, v.2, p.1-7, set.-out. 1926.

OLIVEIRA, M.; DORDAL, R. R,; BARRETO, A. O. Instrucções praticas para o ensino da leitura pelo methodo analytico - modelo de lições. Directoria Geral da Instrucção Publica - São Paulo: Typografia do Diário Official, 1914.

REIS FILHO, C. dos. A educação e a ilusão liberal. São Paulo: Cortez; Autores Associados, 1981.

RIBEIRO, A. I. M. A educação feminina durante o século XIX: o Colégio Florence de Campinas 1863-1889. Campinas: Área de Publicações CMU/Unicamp, 1996.

RIBEIRO, N. R. Um estudo sobre A leitura analytica (1896), de João Köpke. Marília, 2001. 66f. Trabalho de Conclusão de Curso (Graduação em Pedagogia) - Faculdade de Filosofia e Ciências, Universidade Estadual Paulista. 


\section{4 \\ RAMON ROCA DORDAL (1854-1938) \\ e Carlos Alberto Gomes Cardim \\ (1875-1938) NA HISTÓRIA DA ALFABETIZAÇÃO NO BRASIL ${ }^{1}$}

Franciele Ruiz Pasquim

\section{Introdução}

Nas décadas finais do século XIX, intensificou-se a preocupação com a formação de professores primários no Brasil, em especial nos estados do Rio de Janeiro e de São Paulo. Essa foi uma das iniciativas imprescindíveis aos avanços políticos, sociais e educacionais pelos quais o Império brasileiro ansiava e que a República recém-instaurada demandava urgentemente, como forma de reverter condições de precariedade do ensino e erradicar o analfabetismo (Reis Filho, 1981).

A Escola Normal de São Paulo (ENSP) tornou-se polo de inovações educacionais e de modelos pedagógicos, e os professores nela formados passaram a divulgar suas propostas de ensino, seja por meio das "tematizações" sobre o ensino da leitura e escrita em periódicos educacionais, seja por meio da elaboração de cartilhas, nas quais apresentavam o método e o processo que consideravam mais adequados para o ensino da leitura e escrita (Mortatti, 2000).

1 Este texto é resultante de pesquisa de iniciação científica, desenvolvida com Bolsa Pibic/CNPq/Unesp, cujos resultados finais foram apresentados sob a forma de Trabalho de Conclusão de Curso (Pasquim, 2010d). Artigo com conteúdo semelhante encontra-se em Pasquim (2010c) [N.O.]. 
A atuação desses "normalistas" é central nas disputas em torno dos métodos de ensino da leitura e escrita, que caracterizaram o segundo momento na história da alfabetização no Brasil (ibidem).

Dentre esses professores paulistas formados por essa Escola Normal, ${ }^{2}$ destacam-se Ramon Roca Dordal (1854-1938) e Carlos Alberto Gomes Cardim (1875-1938). Ambos foram defensores e divulgadores do método analítico para o ensino da leitura e escrita e concretizaram, por meio da publicação de suas cartilhas, um modo de processar esse método, considerando a rapidez, a facilidade e a eficácia em ensinar a leitura e a escrita. A atuação desses professores é mais um indicativo da ênfase dada, naquele momento histórico, não apenas ao método de ensino de leitura e escrita, mas também ao modo de processar esse método. Esse é o núcleo da disputa entre "modernos" e "mais modernos", característica do segundo momento na história da alfabetização no Brasil (ibidem), para o que contribuíram os professores Dordal e Cardim, cuja atuação é focalizada neste texto.

\section{Aspectos da biografia e atuação profissional}

\section{Ramon Roca Dordal ${ }^{3}$}

Ramon Roca Dordal, filho de dona Francisco Roca y Ardevol e D. B. Ramona Dordal nasceu em 1ํ de março de 1854 na cidade

2 Fazem parte desse "segundo momento" da história da alfabetização e foram estudadas pelos integrantes do GPHELLB, as seguintes cartilhas e seus autores: Cartilha analytica, de Arnaldo de Oliveira Barreto (Bernardes, 2003); Cartilha Proença, de Antônio Firmino de Proença (Gazoli, 2007; 2010); Meu livro, de Theodoro de Moraes (Pereira, 2006; 2009); Cartilha: leituras infantis, de Francisco Vianna (Oriani, 2010); Nova Cartilha Analytico-synthética, de Mariano de Oliveira (Sobral, 2007); e Cartilha infantil pelo methodo analityco [1910?], de Carlos Alberto Gomes Cardim (Pasquim, 2010d).

3 As informações deste tópico foram extraídas de: Ferreira (2002), Martins (2008), Mortatti (2000), Polianteia (1946), Revista IHGSP (1939). Também foram extraídas informações do site Jornal Diário Oficial de Itatiba e da seção "Memorial da Educação" do site do CRE-Mário Covas. Disponíveis respectivamente em: <http://www.itatiba.sp.gov.br/arquivos/22112007.pdf> e em <http://www.crmariocovas.sp.gov.br>. Todos acessados em: 4 ago. 2010. 
de Barcelona, na Espanha. Estudou História e Geografia na Escola San Isidro-Espanha e aprendeu tipografia, e exerceu esse ofício, em Madri, capital daquele país. Além de tipógrafo, foi aspirante oficial de segunda classe de Orense e oficial do batalhão galaico.

Em 1973, com 19 anos, Dordal mudou-se para a cidade de Macaé (RJ) e trabalhou como desenhista da estrada de ferro que ligava os municípios fluminenses de Macaé e Campos. Durante dez anos, na cidade do Rio de Janeiro, trabalhou também como tipógrafo do Jornal do Commercio.

Em 1886, com 32 anos, matriculou-se na ENSP. Diplomado, foi nomeado para a Primeira Cadeira de Itatiba (SP) e foi, posteriormente, o primeiro diretor do Grupo Escolar Cel. "Júlio César" nessa cidade. Lecionou na segunda Escola Modelo na cidade de São Paulo (SP), também chamada "Escola Modelo do Carmo", e, em fevereiro de 1893, foi auxiliar de Alfredo Bresser. Permaneceu nessa escola durante dez anos e exerceu o cargo de diretor do primeiro Grupo Escolar do Braz, que, “[...] dois meses após a morte desse professor, passou a ser denominado Grupo Escolar 'Rocca Dordal', conforme decreto de 02 de dezembro de 1938." (CRE, 2010, n.p.).

Em 1896, Dordal foi colaborador da revista Eschola Publica e integrou, em 1902, o grupo de redatores oficiais da Revista de Ensino, da Associação do Professorado Público Paulista.

Em 1907, foi nomeado inspetor escolar na cidade de São Paulo, cargo que ocupou até o ano de 1919, quando se aposentou.

O professor Ramon Roca Dordal faleceu em 19 de setembro de 1938, com 84 anos de idade.

\section{Carlos Alberto Gomes Cardim 4}

Filho do comendador e maestro João Pedro Gomes Cardim, nascido em Setúbal (península da região de Lisboa, Portugal), e de

4 Para mais informações sobre Carlos Alberto Gomes Cardim, ver, especialmente: Pasquim (2010d) e Mortatti (2000a). 
Ana Amélia Monte Claro Gomes Cardim, (nascida no estado do Rio Grande do Sul, Brasil), Carlos Alberto Gomes Cardim nasceu em 10 de fevereiro de 1875, na cidade de São Paulo (Polianteia, 1946, p.105).

Cardim casou-se com Ignez Lacerda e teve dois filhos (ibidem, p.105): João Carlos Gomes Cardim, que se diplomou médico e professor e exerceu, entre outros, o cargo de diretor superintendente do Instituto de Educação Caetano de Campos; e Carlos Alberto Gomes Cardim Filho, que se diplomou engenheiro e arquiteto pela Escola Normal de Engenharia da Universidade de São Paulo e ocupou, entre outros, o cargo de diretor da Escola de Belas Artes de São Paulo5 (Bueno; Barata, 1999, p.635).

Em 1894, aos 19 anos de idade, Cardim diplomou-se pela ENSP, ${ }^{6}$ iniciando sua carreira no magistério público paulista, e, em 1895, por concurso, ingressou em uma escola isolada na cidade de São Paulo.

$[\mathrm{N}]$ o exercício desta modesta escola isolada, [...] recebeu o honroso convite de Miss Márcia Browne, ${ }^{7}$ para ir trabalhar na Escola

5 Segundo informações contidas no site Escola de Belas Artes de São Paulo, essa escola foi fundada no dia 23 de setembro de 1925, ano em que "[...] Pedro Augusto Gomes Cardim apresentou a um grupo ilustre de homens públicos e artistas, o projeto para a criação da Academia de Belas Artes. A proposta foi bem recebida e a escola foi inaugurada em 15 de fevereiro de 1926 apenas com os cursos de pintura e escultura". Disponível em: <http://www.belasartes. br/institucional/historia.php>. Acesso em: 6 nov. 2010.

6 O período no qual Cardim estudou na ENSP foi após a proclamação da República. Nesse período, a Escola Normal foi reorganizada e nela foram criadas escolas modelos orientadas pelos princípios educacionais de Maria Guilhermina e Miss Browne. Disponível em: <http://www.crmariocovas.sp.gov.br/ neh.php?t=001a>. Acesso em: 6 nov. 2010.

7 Márcia P. Browne, educadora norte-americana, juntamente com “[...] Maria Guilhermina Loureiro de Andrade, que havia estudado quatro anos nos Estados Unidos estudando sistemas de ensino [...] Ambas conhecedoras [...] dos métodos de ensino americanos, iniciaram uma obra verdadeiramente grandiosa, qual a da adaptação de métodos de ensino renovados e eficientes nas escolas-môdelo anexas, que eram destinadas a campo de experimentação de novas técnicas, de observação e prática de ensino para os estudantes 


\begin{abstract}
Modêlo "Prudente de Moraes". ${ }^{8}$ Ai, foi convidado por Gabriel Prestes para trabalhar sob sua direção, como professor no Curso Complementar; trabalhou depois sob a direção de Alberto Sales, como auxiliar do Oscar Thompson, ${ }^{9}$ na Escola Normal, e sob a direção do dr. Rui de Paula Sousa passou a exercer o cargo de inspetor técnico da Escola Normal. (Polianteia, 1946, p.6)
\end{abstract}

Entre 1896 e 1902, Cardim publicou artigos na revista Eschola Publica, publicada pela Typografia Industrial de S. Paulo, e na Revista de Ensino. Esses artigos tratavam de "tematizações" sobre as primeiras preocupações do autor em relação ao ensino de Geometria e da importância do exercício físico e de narrativas sobre episódios históricos.

Em 1908, Cardim foi convidado para organizar e reformar o ensino primário e secundário do estado do Espírito Santo, ${ }^{10}$ tendo exercido o cargo de secretário da Instrução Pública nesse estado. Como parte de suas iniciativas, criou a "[...] Escola Modelo através

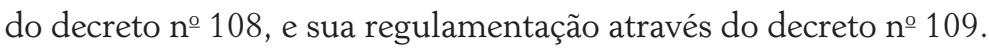
Além de Secretário da Instituição, Gomes Cardim foi nomeado diretor da Escola Modelo e da escola Normal." (Ferreira, 2000, p.2).

de irradiação de ensino remodelado. Numeroso foram os discípulos dessas educadoras, cuja ação na vida prática teve larga influência na remodelação do ensino público paulista e, posteriormente de outros Estados. Foram eles os primeiro s a divulgarem o método analítico para o ensino da leitura, do ensino intuitivo de várias matérias e da prática dos ensinamentos de e da prática dos ensinamentos de Froebel” (Polianteia, 1946, p.94-5).

8 A Escola Normal "Prudente de Morais" foi criada em 1895, por Cesário Mota Junior "[...] a Escola Modêlo da Luz, denominada mais tarde Grupo Escolar Prudente de Moraes.”. Disponíveis em: <http:// www.crmariocovas.sp.gov. br/>. Acesso em: 11 nov. 2010.

9 Oscar Thompson “[...] exerceu vários cargos no magistério e na administração escolar, destacando-se sua atuação como diretora, da Escola Normal de São Paulo (1901 a 1920, com interrupções): incentivador e divulgador do método analítico para o ensino da leitura e da produção de cartilhas assim como de experiências em psicologia científica e em bibliotecas escolares; criador da Directoria Geral da Instrução Publica [...]” (Mortatti, 2000, p.123).

10 A respeito da atuação do professor Gomes Cardim no Espírito Santo, ver especialmente os artigos de Schwartz (2007; 2008). 
Nesse mesmo ano, foi criado o "[...] 1ำ Grupo Escolar do Espírito Santo através do decreto no 166 de 05 de setembro de 1908. O Grupo Escolar recebeu o nome do próprio Secretário da Instrução, Gomes Cardim"11 (ibidem, p.2).

Tendo permanecido durante quatro anos no estado do Espírito Santo, onde esteve à frente das reformas educacionais, em 1913, ao regressar a São Paulo, Cardim foi nomeado "[...] lente de Psicologia e Pedagogia da Escola Normal Secundária de São Paulo" (Melo, 1954, p.129).

Entre 1917 e 1918, Cardim integrou a diretoria da Associação Beneficente do Professorado Público Paulista. Nessa importante associação, participou das comissões responsáveis tanto pela revisão e adoção de livros didáticos como dos relatórios sobre a situação do ensino primário paulista.

Aos 47 anos de idade, Cardim já havia ocupado muito cargos representativos no ensino primário paulista. Além de sua atuação como autor de livros didáticos, foi nomeado, em 1922, diretor da Escola Normal do Braz, ${ }^{12}$ onde permaneceu até o ano de 1924 (Melo, 1954, p.129). Entre 1925 e 1928, foi subdiretor e 15을 Diretor da Escola Normal Secundária de São Paulo ${ }^{13}$ (ibidem, p.129).

Com 31 anos, uma de suas iniciativas como diretor da Escola Normal da Praça foi a criação daquela que ficou conhecida por muitos como a primeira biblioteca infantil do curso primário de São Paulo e do Brasil. Essa biblioteca foi

11 O Grupo Escolar “Gomes Cardim”, atualmente EEEFM “Gomes Cardim”, foi "[...] autorizada a funcionar pela lei 166 de 5 setembro de 1908. Inicialmente instalada na antiga Escola D. Pedro II - atual Escola Estadual Maria Ortiz, localizada no Centro de Vitória. Em 1928, a Escola Primária 'Gomes Cardim', foi instalada no prédio construído especialmente pra abrigá-la”. Disponível em: <http://www.escolagomescardim.com.br. php?pg=historico>. Acesso em: 4 ago. 2010.

12 A Escola Normal do Brás foi criada por decreto de 8 de agosto de 1898. Disponíveis em: <http://www.crmariocovas.sp.gov.br/pdf/neh/19111915/1913_braz.pdf>. Acesso em: 11 nov. 2010.

13 A Escola Normal de São Paulo passou a ser denominada Escola Normal Secundária em 1911. Nesse período, foi diretor Oscar Thompson (Polianteia, 1946). 
[...] fundada em 1925, por iniciativa de Carlos Alberto Gomes Cardim, diretor da Escola Normal de São Paulo, auxiliado pelos professores João Baptista de Brito e Renato Braga, a organização da Biblioteca Infantil ficou de 28 de maio de 1925 a 10 de agosto de 1927, sob o comando da professôra D. Dulce Bressane. Desta data até 1929 foi dirigida pela professora D. Nísia Pereira Bueno. Essa biblioteca foi fechada em 1929. Seus livros foram recolhidos à Biblioteca do Curso Normal. (Jornal Nosso Esfôrço, 1965, n.5 e 7, p.3)

Ainda que, com seus auxiliares, Cardim tentasse impulsionar o ensino da leitura por meio da criação da Biblioteca infantil,

[... ] a frequência dos alunos não era obrigatória: os alunos que quisessem podiam pedir livros para estudar ou distrair-se. Durou só dois anos a biblioteca [...] Foi fechada porque vivia "às moscas" e os livros foram entregues a Biblioteca Paulo Bourroul [...]. (ibidem, n. 8 e 9, p.7)

Cardim foi, ainda, diretor do Conservatório Dramático e Musical de São Paulo, tendo ocupado o cargo de professor catedrático do curso de Música.

Em dois de junho de 1938, faleceu, aos 63 anos de idade, o professor Carlos Alberto Gomes Cardim, na cidade de São Paulo. No ano seguinte a sua morte, recebeu, como homenagem póstuma de seus amigos e discípulos, uma coroa de bronze com as seguintes palavras:

"Educação, Caráter, Coração", dizendo o orado: Esta coroa, que durará eterna como bronze dos sentimentos dos que a idearam, ainda não exprime tudo, porque é pouco como pagamento do que devem ao prof. Gomes Cardim as gerações que se entregou, fixando-se no curso de sua existência como um Homem que Deus quis fosse destinado a não desaparecer mesmo depois de morto, 
porque, para lembrá-lo na memória de todos, havia de ficar sua obra de educação, de caráter e coração... (Polianteia, 1946, p.106).

Em sua homenagem, foi "[...] erigido em bronze, seu busto, ao lado da escola, por seus ex-alunos e amigos" (Jornal Nosso Esfôrço, 1965 , n. 5 e 7, p.8). Para essa homenagem, foi criada uma comissão que tinha por objetivo exaltar a atuação de Cardim, que, segundo eles

[...] havia galgado todos os degraus hierárquicos até assumir a direção da escola, destacando-se sempre como um educador, instruindo e educando dentro dos mais modernos metodos de ensino e imprimindo-lhe orientação nacionalista. (Revista do Professor, n. 6, ano 7, 1950)

\section{Bibliografia de e sobre Dordal e Cardim}

Em Pasquim (2010a) encontram-se reunidas 71 referências de textos escritos por esses professores e 144 referências de outros autores com menções a esses professores, suas atuações profissionais e/ou citações de textos deles. Em Pasquim (2010b) encontram-se reunidas: 40 referências de textos escritos pelo professor Dordal, considerando as diferentes edições de um mesmo texto, e 45 referências de textos de outros autores com menções a Dordal, sua atuação profissional e/ou citações de seus textos. Encontram-se também 31 referências de textos escritos por Cardim e 99 referências de textos de outros autores com menções a Cardim, sua atuação profissional e/ou citações de seus textos.

\section{Bibliografia de Dordal e de Cardim}

No Quadro 1, apresento quarenta referências de textos escritos por Ramon Roca Dordal, que estão ordenadas por tipo de texto e ano de publicação. 
Quadro 1 - Bibliografia de Ramon Roca Dordal por tipo de texto e ano de publicação, entre 1891 e 1933

\begin{tabular}{|c|c|c|c|c|c|}
\hline \multirow{2}{*}{$\begin{array}{r}\text { Tipo de } \\
\text { pesquisa }\end{array}$} & \multicolumn{2}{|c|}{ Livros didáticos } & \multirow{2}{*}{$\begin{array}{c}\text { Artigos em } \\
\text { revistas }\end{array}$} & \multirow{2}{*}{$\begin{array}{c}\text { Documentos } \\
\text { oficiais }\end{array}$} & \multirow{2}{*}{ Total } \\
\hline & Aritmética & Leitura & & & \\
\hline 1891 & 4 & - & - & - & 4 \\
\hline 1896 & - & - & 2 & - & 2 \\
\hline 1902 & 1 & 1 & 4 & - & 6 \\
\hline 1903 & 1 & - & 2 & - & 3 \\
\hline 1906 & 1 & - & - & - & 1 \\
\hline 1908 & 1 & - & - & 2 & 3 \\
\hline 1909 & 1 & 1 & - & - & 2 \\
\hline 1911 & 1 & 2 & - & - & 3 \\
\hline 1913 & - & 1 & - & 1 & 2 \\
\hline 1914 & - & - & 4 & 1 & 5 \\
\hline 1915 & 1 & 1 & - & - & 2 \\
\hline 1916 & - & 1 & - & - & 1 \\
\hline 1921 & - & 1 & - & - & 1 \\
\hline 1922 & - & 2 & - & - & 2 \\
\hline 1925 & - & 1 & - & - & 1 \\
\hline 1927 & - & 1 & - & - & 1 \\
\hline 1933 & - & 1 & - & - & 1 \\
\hline $\begin{array}{c}\text { Total por tipo } \\
\text { de textos }\end{array}$ & 11 & 13 & 12 & 4 & 40 \\
\hline Total geral & & & 40 & & \\
\hline
\end{tabular}

Fonte: Pasquim (2010a)

Conforme os dados apresentados no Quadro 1, é possível observar que a maior quantidade de publicações de Dordal é constituída de livros didáticos (24 referências), escritos exclusivamente por esse professor ou em coautoria com outros autores, sobre os quais, até o momento, não foram localizadas informações.

Segundo Mortatti (2000, p.95), Dordal escreveu a Cartilha moderna, que "[...] parece ter sido publicada em 1902", e apresenta os grandes objetivos de sua Cartilha: "[...] agradar à criança e facilitar 
o trabalho do professor, de modo que o ensino da leitura pelo método analítico se torne agradável e, ao mesmo tempo, viável nas escolas públicas".

Em 1902, Dordal teve publicados na Revista de Ensino quatro artigos sobre o ensino da leitura e da escrita no ensino primário.

No período compreendido entre 1907 e 1918, no qual exerceu o cargo de inspetor-geral da Instrução Pública, no estado de São Paulo, Dordal teve vinte textos publicados, ou seja, mais da metade de toda sua produção escrita.

Observa-se, ainda, que em 1914 Dordal teve a maior quantidade de textos publicados (cinco): o documento oficial intitulado Instruções praticas para o ensino da leitura, pelo methodo analytico - modelos de lições, em coautoria com os professores Mariano de Oliveira e Arnaldo de Oliveira Barreto; e artigos na Revista de Ensino, nos quais afirmava que para "[...] alcançar a regularidade de horário, a uniformidade de programma, será sómente possível com a unidade do livro". (Dordal, 1902, p.589 apud Mortatti, 2000, p.86).

Como informei, dentre as referências de textos de Dordal, destacam-se aquelas de livros didáticos, o que é representativo de sua preocupação com as urgências educacionais da época em que "[...] a consolidação do mercado editorial de livros didáticos produzidos por brasileiros e para escola brasileira [...] esteve [...] relacionada a um tipo de escritor didático profissional: o professor normalista; e de uma especialidade editorial: a publicação de livros didáticos" (Mortatti, 2000, p.85-6).

No Quadro 2 apresento bibliografia de Carlos Alberto Gomes Cardim, constituída de 31 referências de textos escritos por esse professor e ordenadas por tipo de texto e ano de publicação.

Conforme os dados sintetizados no Quadro 2, pude localizar 25 referências de livros didáticos para o ensino de diferentes disciplinas publicados entre os anos 1896 e 1931, período em que se concentram as datas da maior quantidade de referências de textos de Cardim. 


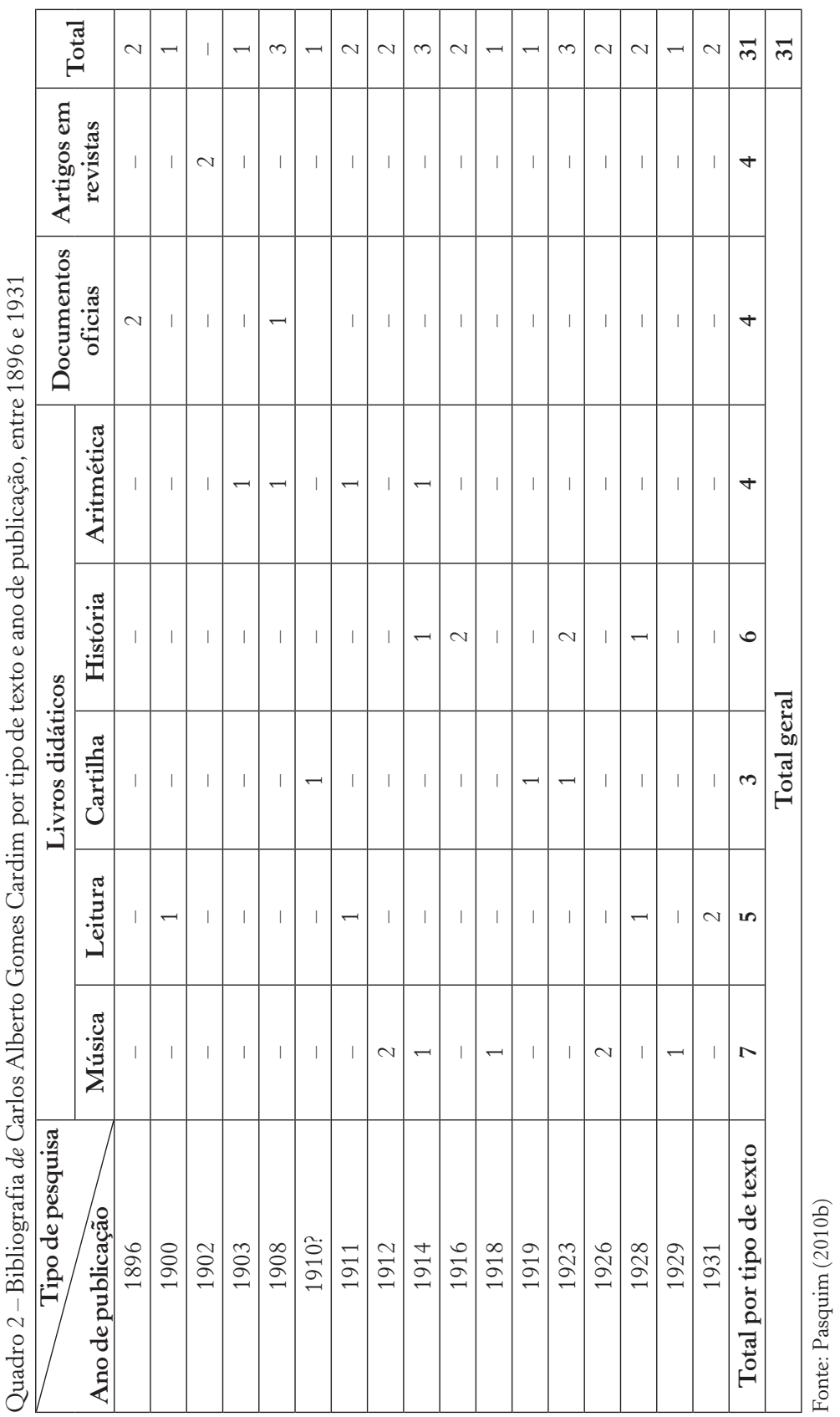


Em 1896, Cardim teve publicados alguns artigos na revista Eschola Publica, publicada pela Typ. Industrial de S. Paulo. Presumivelmente em 1910, Cardim teve publicada a Cartilha infantil pelo methodo analytico, ${ }^{14}$ que alcançou a 9a edição em 1919 e a 11a em 1923. Ambas as edições foram publicadas pela Typografia Augusto Siqueira em São Paulo.

É possível afirmar que Cardim prescreveu aos professores a utilização de sua cartilha para o ensino de leitura e escrita quando foi convidado pelo presidente João Monteiro para participar da reorganização do ensino primário e secundário na província do Espírito Santo, entre os anos de 1909 e 1913. Além dessa cartilha, Cardim teve publicados livros didáticos para o ensino de história e música e artigos em periódicos educacionais, que circularam entre o professorado paulista.

Embora pequena, a produção bibliográfica de Cardim é indicativa de sua preocupação em atender às necessidades sociais e educacionais de sua época, uma vez que nesse momento foi instituído o método analítico para o ensino de leitura e escrita, a fim de reverter o analfabetismo.

\section{Bibliografia sobre Dordal e sobre Cardim}

Em relação à bibliografia sobre Ramon Roca Dordal, localizei 45 referências de textos de outros autores, com menções a esse professor, sua atuação profissional e/ou citações de seus textos. Essas referências estão ordenadas em seis subseções, de acordo com o tipo de texto: menções e/ou citações em livros (onze referências); dicionários, enciclopédia e catálogo de fontes (duas referências); textos acadêmicos (dezesseis referências); artigos de revistas (dez referências); documentos oficiais (cinco referências); artigo de jor-

14 Segundo Cardim (1919), essa cartilha seguia o processo de sentenciação que consistia em iniciar a leitura das sentenças, primeiramente pelo aluno sozinho e posteriormente pelos demais alunos, seguindo-se a decomposição das sentenças em palavras, das palavras em sílabas e das sílabas em letras. 
nal (uma referência). O primeiro texto é de 1902, e o último data de 2010.

A seção Bibliografia sobre Carlos Alberto Gomes Cardim contém 99 referências de texto de outros autores, com menções a Cardim, sua atuação profissional e/ou citações de seus textos. Essas referências estão ordenadas em oito subseções, de acordo com o tipo de texto: menções e/ou citações em livros (28 referências); dicionários, enciclopédia e catálogo de fontes (nove referências); textos acadêmicos (21 referências); revistas e artigos de revistas (oito referências); anais de evento (quinze referências); documentos oficiais (três referências); artigos de jornais (seis referências); e anúncios de revistas (nove referências). O primeiro texto é de 1908, e último data de 2010.

Observa-se que a maior quantidade de textos de outros autores, com menções a Cardim e a Dordal, suas atuações profissionais ou citações de seus textos, concentra-se respectivamente em: trabalhos acadêmicos (dezesseis referências); e em livros (28 referências). Essa maior concentração deve-se à atuação desses professores no estado de São Paulo, e, no caso de Cardim, também a sua atuação no estado do Espírito Santo.

\section{Considerações finais}

Como se pode observar, Cardim e Dordal contribuíram ativamente no momento histórico em que atuaram, integrando grupo de professores escritores de cartilha que se baseavam no método analítico. Por ter sido esse método considerado o mais eficaz, foi institucionalizado pelas autoridades da instrução pública paulista na tentativa de responder às urgências sociais daquele momento (Magnani, 1997; Mortatti, 2000).

Assim, o estudo sobre a produção didática de ambos contribui para compreender melhor o lugar que ocuparam na história do ensino de leitura e escrita no Brasil. 


\section{Referências bibliográficas}

BARATA, C. E.; CUNHA, A. H. B. Dicionário das famílias brasileiras. São Paulo: Ibero, 1999. v.2.

BELLOTTO, H. L. Os instrumentos de pesquisa no processo historiográfico. In: Congresso Brasileiro de Arquivologia, 4, 1979, Anais..., p.133-47.

BERNARDES, V. C. Um estudo sobre Cartilha analytica, de Arnaldo de Oliveira Barreto (1969-1925). Marília, 2003. 67f. Trabalho de Conclusão de Curso (Graduação em Pedagogia) - Faculdade de Filosofia e Ciências, Universidade Estadual Paulista.

BRASLAVSKY, B. P. de. Problemas e métodos no ensino da leitura. Tradução de Agostinho Minicucci. São Paulo: Melhoramentos, 1971.

BUENO, A. H. da C.; BARATA, C. E. de A. Dicionário das famílias brasileiras. v.1. [s.1]: [s.n.], 1999.

CARDIM, C. A. G. C. Cartilha infantil pelo methodo anlalytico. 9.ed. Typographia Augusto Siqueira: São Paulo, 1919.

CRE-Mário Covas. Disponível em: <http://www.crmariocovas.sp.gov. br/pdf/neh/1897-1903/1898-Terceiro_Grupo_Escolar_do_Braz. pdf $>$. Acesso em: 10 abr. 2010.

DORDAL, J. M. Notas biográficas do Prof. Ramon Roca Dordal: sócio falecido do instituto. Revista do IHGSP Instituto de História e Geografia de São Paulo, São Paulo, v.27, p.281, 1939.

FERREIRA, A. C. A epopeia bandeirante: letrados, instituições, invenção histórica 1870/1940. São Paulo: Editora Unesp, 2002.

FICHER, S. Os arquitetos da poli: ensino e profissão em São Paulo. São Paulo: Edusp, 2005.

GAZOLI, M. R. O método analítico para o ensino da leitura em Cartilha Proença (1926), de Antonio Firmino de Proença. Marília, 2007. 92f. Trabalho de Conclusão de Curso (Graduação em Pedagogia) - Faculdade de Filosofia e Ciências, Universidade Estadual Paulista.

O método analítico para o ensino da leitura em "Série de leitura Proença” (1926-1928), de Antonio Firmino de Proença. Marília, 2010, 209f. Dissertação (Mestrado em Educação) - Faculdade de Filosofia e Ciências, Universidade Estadual Paulista.

GRISI, R. O ensino da leitura: o método e a cartilha. São Paulo: Imprensa Oficial do Estado, 1946. (Separata da revista Educação).

JORNAL NOSSO ESFÔRÇO. Órgão do Curso Primário do Instituto de Educação "Caetano de Campos", n. 5 e 7, ano XXIX. São Paulo, nov.-dez. 1965. 
MAGNANI, M. do R. M. Os sentidos da alfabetização: a "questão dos métodos" e a constituição de um objeto de estudo (São Paulo: 1876/1994). Presidente Prudente, 1997. 389f. Tese (Livre-Docência em Metodologia do Ensino de 1ํGrau: Alfabetização) - Faculdade de Ciência e Tecnologia, Universidade Estadual Paulista.

MARTINS, A. L. Revistas em revista: imprensa e práticas culturais em tempos de república, São Paulo (1890-1922). São Paulo: Edusp, 2008.

MELO, L. C. Dicionário de autores paulistas. São Paulo: Irmãos Andriolis, 1954.

MORTATTI, M. do R. L. Os sentidos da alfabetização: São Paulo 1876/1994. São Paulo: Editora Unesp, 2000.

. Ensino de língua e literatura no Brasil: repertório documental republicano. Marília, 2003. (Digitado).

ORIANI, A. P. O método analítico para o ensino da leitura em Cartilha: leituras infantis [1912?], de Francisco Vianna. Projeto de pesquisa. Marília, 2009. (Digitado).

PASQUIM, F. R. P. Bibliografia de e sobre R. R. Dordal (1854-1938): um instrumento de pesquisa. Marília, 2010a. (Digitado).

Bibliografia de e sobre C. A. G. Cardim (1875-1938): um instrumento de pesquisa. Marília, 2010b. (Digitado).

Ramon Roca Dordal (1854-1938) e Carlos Alberto Gomes Car$\operatorname{dim}$ (1875-1938) na história da alfabetização no Brasil. Revista de Iniciação Científicada FFC, Marília, v.10, n.2. p.1-14, 2010c.

.Um estudo sobre Cartilha infantil pelo methodo analityco [1910?], de Carlos Alberto Gomes Cardim (1875-1938). Marília, 2010d. $103 f$. Trabalho de Conclusão de Curso (Graduação em Pedagogia) - Faculdade de Filosofia e Ciências, Universidade Estadual Paulista.

PEREIRA, B. C. Um estudo sobre Meu livro (1909), de Theodoro de Moraes. Marília, 2006. 72f. Trabalho de Conclusão de Curso (Graduação em Pedagogia) - Faculdade de Filosofia e Ciências, Universidade Estadual Paulista.

Theodoro de Moraes (1877-1956): um pioneiro no ensino da leitura pelo método analítico no Brasil. Marília, 2009. 219f. Dissertação (Mestrado em Educação) - Faculdade de Filosofia e Ciências, Universidade Estadual Paulista.

POLIANTEIA, comenmorativa do 1 Centenário do Ensino Normal de São Paulo. São Paulo: Gráfica Brescia, 1946.

REIS FILHO, C. A educação e a ilusão liberal. São Paulo: Cortez, 1981. 
REVISTA DO PROFESSOR. São Paulo, Centro do Professorado Paulista, n.6, ano VII, nov. 1950. (segunda fase)

SOBRAL, P. de O. Um estudo sobre Nova Cartilha Analytico-Synthética (1916), de Mariano de Oliveira. Marília. 2007. 60 f. Trabalho de Concusão de Curso (Graduação em Pedagogia) - Faculdade de Filosofia e Ciências, Universidade Estadual Paulista "Júlio de Mesquita Filho", 


\section{5 \\ Arnaldo de Oliveira Barreto \\ (1869-1925): ATUAÇÃO E PRODUÇÃO PARA O ENSINO DA LEITURA ${ }^{1}$}

Vanessa Cuba Bernardes

\section{Introdução}

Nas últimas décadas, no Brasil, intensificou-se a produção acadêmico-científica sobre a história da alfabetização baseada, sobretudo, em investigações sobre práticas, produção, utilização e circulação de materiais destinados ao ensino da leitura nas escolas primárias brasileiras. Conhecer aspectos da história da alfabetização no Brasil implica conhecer também a atuação e produção escrita de educadores que produziram materiais utilizados no ensino da leitura e escrita nas escolas primárias brasileiras.

No segundo momento da história da alfabetização no Brasil (Mortatti, 2000a; 2010), a atuação dos professores formados pela Escola Normal de São Paulo (ENSP) foi caracterizada pela defesa do método analítico para o ensino da leitura e escrita no âmbito de pelo menos dois tipos de disputas inter-relacionadas: a disputa entre os defensores dos métodos sintéticos - que, além de defender esses métodos por considerá-los mais rápidos e eficientes do que os

1 Este texto é resultante de pesquisa de Iniciação Científica, desenvolvida com bolsa Pibic/CNPq/Unesp, cujos resultados finais foram apresentados sob a forma de Trabalho de Conclusão de Curso (Bernardes, 2003). Artigo com conteúdo semelhante encontra-se em Bernardes (2008) [N. O.]. 
analíticos, continuavam produzindo cartilhas neles baseadas - e os defensores do "novo e revolucionário" método analítico para o ensino da leitura; e a disputa entre os defensores do método analítico "modernos" e "mais modernos" - travada em torno dos diferentes modos de se processar o método analítico para o ensino da leitura - a palavração, a sentenciação ou a historieta (ibidem).

Dentre esses, destaca-se Arnaldo de Oliveira Barreto (18691925), cuja atuação e produção didática são problematizadas neste artigo, com o objetivo de contribuir para a compreensão de seu lugar nas disputas ocorridas no "segundo momento" (idem, 2000) da história do ensino da leitura e escrita em nosso país. Sua intensa atuação profissional e significativa produção escrita exerceram considerável influência sobre educadores de sua época e de décadas posteriores no que se refere ao ensino da leitura nas escolas primárias brasileiras.

\section{Aspectos da vida e atuação profissional de Arnaldo de Oliveira Barreto²}

Arnaldo de Oliveira Barreto nasceu em Campinas (SP), em 12 de setembro de 1869, e faleceu na cidade de São Paulo, em 24 de julho de 1925. Era filho de um farmacêutico gaúcho, Antonio Jesuino de Oliveira, e de Aristhéia Brazilian de Lemos Barreto, natural do estado da Bahia, e irmão de René de Oliveira Barreto, também educador paulista e escritor de livros didáticos.

Iniciou seus estudos, aos 7 anos, no Collégio Morton, tradicional instituição de ensino de Campinas, que, na época, era uma das melhores do país em virtude da erudição de seu corpo docente. Em 1889, após ser aprovado com distinção nos exames de suficiência, matriculou-se na ENSP, tendo-se diplomado em 1891. A partir de então, passou a integrar

2 As informações constantes deste tópico foram extraídas de Melo (1954), Mortatti (2000a) e D’Ávila (1945). 
[...] uma geração de normalistas que, após a Proclamação da República, passa - em substituição ao bacharel em Direito - a ocupar cargos na administração educacional, liderar movimentos associativos do magistério, assessorar autoridades educacionais e produzir material didático e de divulgação das novas ideias, especialmente no que diz respeito ao ensino da leitura. (idem, 2000a, p.78)

Em 1894, passou a reger uma das classes da Escola-Modelo do Carmo, anexa à ENSP. Em 1896, encarregado pelo secretário do Interior, reorganizou o Grupo Escolar de Lorena (SP) e, em seguida, voltou a ocupar seu cargo de professor naquela escola-modelo paulistana. Em 1897, atendendo à solicitação do diretor da ENSP, tornou-se inspetor das escolas anexas desse estado.

Em 1901, foi criada "[...] a desejada e esperançosa corporação de professores [...]” (D’Ávila, 1945, p.232), a Associação Beneficente do Professorado Público de São Paulo, em cujos estatutos incluía-se a publicação de uma revista - a Revista de Ensino - , que circulou entre 1902 e 1918, tendo-se tornado um veículo da propagação, entre outros, do método analítico para o ensino da leitura. No período de 1902 a 1904, Barreto foi redator-chefe dessa revista, tendo sido acompanhado por um corpo de redatores, participantes de um grupo representativo de normalistas paulistas que, assim como Barreto, esteve sempre próximo dos órgãos oficiais da instrução pública paulista. Desse grupo faziam parte Romão Puiggari, Joaquim Luiz de Brito, João Pinto e Silva, João Lourenço Rodrigues, Alfredo da Silveira, Ramon Roca Dordal ${ }^{3}$ e João Crisostomo Bueno dos Reis Junior.

Em 1908, o secretário do Interior do Estado de São Paulo, Cardoso de Almeida, entregou a Barreto a direção do Colégio de Campinas. Após exercer essa função, Barreto foi para a cidade de São Paulo, onde ocupou o cargo de diretor da Escola Normal da Praça da República, nos anos 1924 e 1925.

3 Informações sobre Ramon Roca Dordal encontram-se em texto de Franciele Ruiz Pasquim que integra este livro. Estudo minucioso sobre esse autor foi desenvolvido por Magnani (1997), Mortatti (2000) e Pasquim (2010c). 
No período de 1915 a 1925, Barreto organizou a Coleção Biblioteca Infantil, da Companhia Melhoramentos (SP); em 1915, foi publicado o primeiro título dessa coleção: $O$ patinho feio, de $\mathrm{H}$. C. Andersen. Nesse período, Barreto organizou e recriou 28 contos para essa coleção, e, em 1924, um ano antes de falecer, organizou o catálogo de tal coleção. ${ }^{4}$

\section{Produção escrita de Arnaldo de Oliveira Barreto}

Concomitante à atuação no magistério e à ocupação de cargos da administração escolar, Barreto iniciou sua produção escrita buscando concretizar e divulgar as discussões e os progressos pedagógicos da época relacionados ao ensino da leitura.

A produção escrita de Barreto iniciou-se com a publicação de Cartilha das mães, presumivelmente em 1896, pela Livraria Francisco Alves (RJ). Cartilha das mães foi produzida no momento em que as discussões acerca do método analítico iniciavam-se entre os normalistas e baseava-se no método que Barreto denominou "analytico-synthetico", o qual abandonou anos mais tarde para defender o método analítico.

Após a publicação de sua primeira cartilha, Barreto publicou, em 1896, seu primeiro livro de leitura, Leituras moraes, também editado pela Livraria Francisco Alves (RJ).

Entre os livros de leitura escritos por Barreto, têm-se, ainda: Leitura manuscripta, escrito em colaboração com o professor paulista Ramon Roca Dordal e publicado na década de 1900 pela Livraria Francisco Alves; Varios estylos, publicado na década de 1910 pela Weiszflog Irmãos (SP); e os quatro volumes de Livros de leitura da Série Puiggari-Barreto, escritos em colaboração com o professor paulista Romão Puiggari e publicados em meados da década de

4 A respeito da atuação de Barreto na Companhia Melhoramentos e, principalmente, como organizador da Coleção Biblioteca Infantil, ver, especialmente, tese de Menin (1999), desenvolvida no âmbito do GPHELLB. Sobre a participação de Lourenço Filho nessa Coleção ver, também, Bertoletti (2006) e texto de Estela Natalina Mantovani Bertoletti que integra este livro. 
1890 - 1e e 2o volumes - e no início da década de 1900 - 3ํe 4o volumes - todos pela Livraria Francisco Alves (RJ).

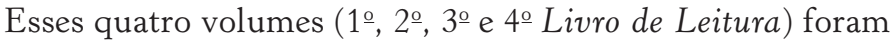
adotados não somente em São Paulo como também nos Estados da Bahia, de Santa Catarina, do Espírito Santo e outros. Em 1904, conquistaram a medalha de prata da Exposição Universal realizada em Saint Louis, nos Estados Unidos. Com suas páginas em branco e preto e algumas em cores, seu texto simples, leve e frequentemente bem-humorado, cheio de ação e de diálogos, suas lições ingênuas e vivazes de boas maneiras, tolerância, respeito e afeição, os Livros de Leitura da série Puiggari-Barreto fogem completamente ao antigo esquema do livro didático de leitura árida, sem vida e sem interesse. (Pfromm Neto; Rosamilha; Dib, 1974, p.175-6)

Além de Cartilha das mães, Barreto publicou em 1909, pela Francisco Alves ${ }^{5}$ (RJ), Cartilha Analytica, ${ }^{6}$ para concretizar o método analítico que defendia para o ensino da leitura a crianças na fase inicial de escolarização.

Barreto integrava, com destaque, o grupo de educadores paulistas que travaram disputas sobre os métodos de ensino de leitura e escrita naquele momento histórico (Magnani, 1997; Mortatti, 2000a; 2010). Em decorrência dessas disputas, esses professores passaram a produzir, no final da década de 1890 e durante as décadas de 1900 e 1910, uma quantidade significativa de cartilhas baseadas programaticamente nesse método e distintas apenas nos diferentes modos de processuação. Isso se deu uma vez que se acirravam as discussões acerca do método analítico para o ensino da leitura e escrita, baseadas principalmente nas:

5 Segundo Hallewell (1985), desde o final do século XIX, a Livraria Francisco Alves publicava livros didáticos e, segundo esse pesquisador, foi a primeira editora brasileira que focalizou suas atividades na publicação de tais livros, chegando a ter, no início do século XX, o quase monopólio do campo do livro didático brasileiro e tendo publicado livros, cartilhas, compêndios etc. muito utilizados nas escolas brasileiras.

6 Análise detalhada sobre essa cartilha encontra-se em Bernardes (2003). 
[...] contribuições da pedagogia norte-americana, divulgadas inicialmente no estado de São Paulo pelas reformas da instrução pública na década de 1890 e posteriormente disseminadas para outros estados brasileiros, por meio de "missões de professores" paulistas. (Mortatti, 2000b, p.43)

Algumas dessas cartilhas produzidas por professores "normalistas" que "[...] assessoravam autoridades da administração educacional e cujas propostas ganharam espaço institucional [...]" (idem, 2000a, p.82) foram adotadas oficialmente após a institucionalização do método analítico para o ensino da leitura nas escolas públicas paulistas durante a primeira gestão de Oscar Thompson na Diretoria-Geral da Instrução Pública paulista, entre 1909 e 1910.

É importante destacar que outro fator que impulsionou a produção de cartilhas foi o processo de expansão e consolidação do mercado editorial de livros didáticos produzidos por brasileiros e para a escola brasileira. Nesse processo, teve papel de destaque a Livraria Francisco Alves, com a qual Barreto tinha contrato de publicação da Cartilha analytica.

Ao escrever essa cartilha, Barreto concretizou o método analítico que defendia para o ensino da leitura e escrita, método que se baseava na "historieta", considerada o "todo" a ser "analisado", gradativa e sequencialmente, até suas menores "partes" constitutivas (sentenças, palavras, sílabas, letras), sempre com predomínio da visão do "todo" e condução por parte do professor.

Cartilha analytica representa uma síntese do conjunto de princípios e conceitos que passaram a fundamentar as discussões sobre educação e, mais diretamente, sobre o ensino da leitura e escrita: a busca da cientificidade na educação da criança; os conceitos, deduzidos a partir da psicologia da infância, que deveriam guiar o professor nos modos de ensinar; os novos métodos de ensino; a hegemonia dos métodos intuitivos e analíticos para o ensino de todas as matérias, principalmente da leitura; os princípios que deveriam encaminhar o método analítico; um ensino que levasse em conta o desenvolvimento e interesse da criança. Com a produção dessa car- 
tilha, Barreto parece ter facilitado o acesso dos professores a essas discussões e, principalmente, à prática do método analítico para o ensino da leitura e escrita. Portanto, Cartilha analytica pode ser considerada representativa não somente da obra desse educador, mas também do momento histórico de sua produção e circulação.

Barreto escreveu também vários textos de literatura infantil, tanto em prosa quanto em verso, que foram publicados em revistas pedagógicas paulistas como Revista Escolar, Revista da Sociedade de Educação e, principalmente, Revista de Ensino, nesta última no período em que Barreto foi seu redator-chefe.

Em 1909, Barreto traduziu o livro Palestras sobre ensino, de Francis Parker, publicado na Coleção Biblioteca Pedagógica, organizada por ele em colaboração com José Stott e editada pela Typ. Livro Azul, de Campinas (SP), e que trata dos procedimentos do ensino da leitura. Os capítulos desse livro foram publicados, em separado, na Revista Escolar, no período compreendido entre janeiro de 1925 e agosto de 1926, sendo cada capítulo em um número dessa revista.

Em decorrência de sua experiência como professor e autor de cartilhas e das discussões e necessidades do momento histórico em que atuou, Arnaldo de Oliveira Barreto participou da elaboração do documento oficial intitulado Instrucções praticas para o ensino da leitura pelo methodo analytico - modelo de lições, assinado por ele e pelos professores paulistas Mariano de Oliveira e Ramon Roca Dordal e expedido pela Diretoria-Geral da Instrução Pública paulista, em 1914, em decorrência da oficialização do método analítico para o ensino da leitura em grupos escolares da capital e do interior do estado de São Paulo (ibidem). Esse documento visava à uniformização do método de ensino da leitura, divulgando o método analítico que partia da historieta e servia como base para a avaliação das cartilhas que passaram a ser adotadas oficialmente após a institucionalização do método analítico. À época, o processo de adoção das cartilhas ocorria da seguinte maneira:

Mediante pareceres de "comissões de especialistas", essas cartilhas eram indicadas às autoridades educacionais e, uma vez 
aprovadas, passavam a ser adotadas - entendendo "adoção" como oficialização e aquisição - pelo Estado, para uso nas escolas primárias paulistas, com a finalidade de uniformizar o ensino da leitura. (ibidem, p.87)

Em 1916, Barreto concedeu uma entrevista ao jornal O Commercio de S. Paulo, na qual tratava também do método analítico para o ensino da leitura.

Entre os anos de 1915 e 1924, Barreto recriou/adaptou 28 contos que foram publicados, pela Companhia Melhoramentos (SP), em livros de literatura infantil da Coleção Biblioteca Infantil. Esses livros foram publicados por várias décadas subsequentes, e há um aspecto relevante sobre a quantidade total de volumes dessa coleção, pois se sabe que: "Até 1957, segundo levantamento realizado pela Melhoramentos, foram publicados 100 títulos nessa coleção e em todos eles, Arnaldo de Oliveira Barreto aparece como organizador e recriador dos contos, embora tenha falecido em 1925" (Menin, 1999, p.154). Diante dessas informações, podemos inferir que talvez a Companhia Melhoramentos tenha decidido fazer uma homenagem ao idealizador da Coleção Biblioteca Infantil, conservando seu nome na capa de todos os volumes publicados por essa coleção, mesmo após seu falecimento.

Barreto escreveu vários textos, publicados em revistas pedagógicas paulistas, que abordavam diversas temáticas: críticas de livros didáticos; discussões sobre os aspectos teórico-metodológicos do ensino da Aritmética, da Biologia e, principalmente, do método analítico para o ensino da leitura, o que vem confirmar a importância desse método à época e o que fez com que Barreto se tornasse "[...] um dos principais divulgadores e polemistas em relação ao método analítico para o ensino da leitura.” (Mortatti, 2000a, p.78).

A obra didática de Barreto, que se iniciou em meados da década de 1890, foi muito utilizada nas escolas brasileiras, conforme se pode observar pelo número de edições que seus livros e suas cartilhas tiveram: Leituras moraes, em 1912, já estava na 12a edição; Cartilha das mães, em 1950, alcançou a 66aㅡ edição, e na página de 
rosto da 52a edição, publicada em 1941, há a seguinte informação: "[...] obra aprovada pelo Concelho Superior de Instrução Publica do Estado de S. Paulo e adotada em todas as suas escolas e em muitos colegios particulares"; Cartilha analytica alcançou, em 1967, a $74^{\mathrm{a}}$ edição.

\section{Considerações finais}

No período compreendido entre 1890 e meados da década de 1920, o método analítico para o ensino da leitura e escrita foi foco central das discussões relacionadas à educação e direcionadas pelos "normalistas", os quais, na condição de administradores educacionais, divulgaram e ensinaram os professores a aplicar as novas propostas para o ensino da leitura e escrita por meio das cartilhas por eles produzidas e que tiveram forte repercussão entre os professores primários, nas décadas seguintes, alcançando, assim, dezenas e até centenas de edições (Magnani, 1997; Mortatti, 2000a; 2010).

Como se pôde observar, a atuação profissional de Arnaldo de Oliveira Barreto e sua profícua produção - cartilhas e livros de leitura, artigos para revistas, documentos oficiais, textos pedagógicos traduzidos e contos infantis recriados -, por meio da qual buscou disseminar o método analítico para o ensino da leitura, dialogam diretamente com as discussões sobre o ensino da leitura e escrita ocorridas nesse período e confirmam a importância desse educador e de sua obra para a história da alfabetização no Brasil.

\section{Referências bibliográficas}

BERNARDES, V. C. Um estudo sobre Cartilha analytica, de Arnaldo de Oliveira Barreto (1969-1925). Marília, 2003. 67f. Trabalho de Conclusão de Curso (Graduação em Pedagogia) - Faculdade de Filosofia e Ciências, Universidade Estadual Paulista.

Um estudo de Cartilha analytica. Revista de Iniciação Científica da FFC, v.8, n.1, p.1-17, 2008. Disponível em: <http://www.portalppgci. 
marilia.unesp. br/ric/viewarticle.php?id=130\&layout=abstract $>$. Acesso em: jun. 2014.

BERTOLETTI, E. N. M. A produção de Lourenço Filho sobre e de literatura infantil e juvenil (1942-1968): fundação de uma tradição. Marília, 2006. 275f. Tese (Doutorado em Educação) - Faculdade de Filosofia e Ciências, Universidade Estadual Paulista.

D’ÁVILA, A. René e Arnaldo Barreto. Educação, São Paulo, v.33, n.46/47, p.230-3, jan./jun. 1945.

MAGNANI, M. do R. M. Os sentidos da alfabetização: a "questão dos métodos" e a constituição de um objeto de estudo (São Paulo/18761994). Presidente Prudente, 1997. 389f. Tese (Livre-Docência em

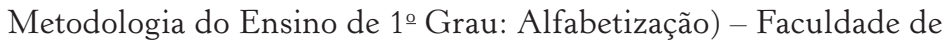
Ciências e Tecnologia, Universidade Estadual Paulista.

MELO, L. C. de. Dicionário de autores paulistas. São Paulo: [s.n.], 1954. (Comissão do IV centenário da cidade de São Paulo).

MENIN, A. M. C. S. O patinho feio, de H. C. Andersen: o "abrasileiramento" de um conto para crianças. Assis, 1999. 2v. Tese (Doutorado em Letras) - Faculdade de Ciências e Letras, Universidade Estadual Paulista (v.1, 280f; v.2, Anexos).

MORTATTI, M. do R. L. Os sentidos da alfabetização (São Paulo 1876/1994). São Paulo: Editora Unesp; Brasília: MEC/Inep/Comped, 2000a.

. Cartilha de alfabetização e cultura escolar: um pacto secular. Cadernos Cedes, ano19, n.52, p.41-54, nov. 2000b.

Antonio Firmino de Proença na história da alfabetização no Brasil. In: RAZZINI, M. de P. G. (org.). Antonio Firmino de Proença: professor, formador, autor. São Paulo: Porto de Ideias, 2010, p.117-39. v.1.

PASQUIM, F. Um estudo sobre Cartilha infantil pelo methodo analityco [1910?], de Carlos Alberto Gomes Cardim (1875-1938). Marília, 2010. 103f. Trabalho de Conclusão de Curso (Graduação em Pedagogia) Faculdade de Filosofia e Ciências, Universidade Estadual Paulista.

PFROMM NETO, S; ROSAMILHA, N.; DIB, C. Z. Cartilhas, gramáticas, livros de texto. In: O livro na educação. Rio de Janeiro: Primor; INL, 1974, p. 153-204.

SOBRAL, P. de Ol. Um estudo sobre Nova cartilha analytico-synthética (1916), de Mariano de Oliveira. Marília, 2007. 65f. Trabalho de Conclusão de Curso (Graduação em Pedagogia) - Faculdade de Filosofia e Ciências, Universidade Estadual Paulista. 


\section{6 \\ A ATUAÇÃO PROFISSIONAL \\ E A PRODUÇÃO ESCRITA DE FRANCISCO \\ VIANNA (1876-1935) NA HISTÓRIA \\ DO ENSINO DA LEITURA ${ }^{1}$}

Angélica Pall Oriani

\section{Introdução}

Frases como "Ivo viu a uva" e "Eva viu a ave" são bastante conhecidas no meio educacional. Não é o caso, entretanto, do autor dessas frases, Francisco Vianna (1976-1935). A atuação desse professor e sua produção escrita, apesar de demonstrarem bastante envolvimento com as questões educacionais, ficaram subsumidas na atuação representativa e renomada de outros professores que atuaram no mesmo momento histórico que Francisco Vianna.

Apesar do desconhecimento da figura desse professor, seus livros para o ensino da leitura circularam e foram republicados durante pelo menos quatro décadas, até mesmo após o falecimento do autor. Buscando trazer à tona a produção escrita desse professor para o ensino da leitura e articulá-la, principalmente, à sua atuação profissional no segundo momento da história da alfabetização no Brasil (Magnani, 1997; Mortatti, 2000a), o objetivo deste texto é

1 Este texto é resultante de pesquisa mestrado, desenvolvida com Bolsas CNPq e Fapesp, cujos resultados finais foram apresentados sob a forma de dissertação de mestrado (Oriani, 2010) [N.O.]. 
problematizar o lugar desse professor nessa história, de modo a apresentar e problematizar sua atuação praticamente desconhecida.

\section{Francisco Vianna: professor e autor de livros didáticos ${ }^{2}$}

Francisco Furtado Mendes Vianna viveu 59 anos, tendo nascido em 1876 e falecido em 1935. Com 12 anos, foi morar sob os cuidados de seu tio Godofredo José Furtado, professor na Escola Normal de São Paulo (ENSP), positivista e presidente da Sociedade Positivista de São Paulo. Aos 17 anos, ingressou na ENSP, tendo-se diplomado em 1895, aos 19 anos.

Depois de formado, Francisco Vianna exerceu diferentes cargos no âmbito educacional, tendo sido: professor na 2 a Escola Complementar, anexa à antiga Escola Modelo "Prudente de Moraes", em São Paulo (SP), entre 1895 e 1904; diretor do Grupo Escolar "Cardoso de Almeida", em Botucatu (SP), entre 1904 e 1906; professor da 12 cadeira de "História Natural" no Ginásio do Estado em Campinas (SP), entre 1906 e 1910; ${ }^{3}$ e inspetor do ensino secundário, no Rio de Janeiro (RJ), então Distrito Federal, presumivelmente entre 1915 e 1935, ano em que faleceu.

Ao longo de sua atuação profissional, Francisco Vianna escreveu vários livros didáticos, os quais foram publicados pela Livraria Francisco Alves - no caso dos livros de leitura e de história -, pela Companhia Melhoramentos de São Paulo (Weiszflog Irmãos Incorporada), atualmente Editora Melhoramentos ${ }^{4}$ - no caso dos

2 As informações a respeito da vida de Francisco Vianna são bastante difusas, e o que localizei a respeito desse professor está divulgado esparsamente em diferentes meios, entre eles, Magnani (1997) e Mortatti (2000a).

3 De acordo com Silva (1935), Francisco Vianna também foi lente da cadeira de "História Natural" no Ginásio do Estado de Campinas.

4 Segundo informações localizadas em Hallewell (1985), a Companhia Melhoramentos de São Paulo foi responsável pela publicação de diversos livros didáticos e outros materiais escolares nas décadas iniciais do século XX. A respeito dessa editora, ver especialmente Donato (1990), Hallewell (1985) e Razzini (2007). 
cadernos de caligrafia - , e pela Typographia da Industrial de São Paulo ${ }^{5}$ e depois pela Espíndola, Siqueira \& Co. ${ }^{6}$ - no caso do livro para o ensino de trigonometria.

A produção escrita de Francisco Vianna indica, portanto, o intenso envolvimento desse professor com as questões relativas ao ensino. Sua produção didática destinada à leitura é composta por sete livros que integram a Série Leituras Infantis. ${ }^{7}$ Entre as referências que localizei, têm-se: duas de cartilhas: Cartilha: leituras infantis [1912?] ${ }^{8}$ e Primeiros passos na leitura (1915); e cinco de livros de leitura: Leitura preparatória, escrito em colaboração com Miguel Carneiro Júnior (1908); Primeiro livro de leituras infantis (1908); Segundo livro de leituras infantis (1908); Terceiro livro de leituras infantis (1908); e Quarto livro de leituras infantis: apanhados e factos históricos (1919).

Os livros dessa série tiveram grande circulação em diversos estados brasileiros - São Paulo, Rio de Janeiro, Mato Grosso, Espírito Santo, Paraná, Pará, Amazonas, Ceará, Minas Gerais, Santa Catarina e Rio Grande do Sul - , tendo tido novas edições publicadas mesmo após a morte desse professor. As edições mais recentes dos livros dessa série foram publicadas entre as décadas de 1940, 1950 e 1960, tendo todas ultrapassado a 40aㅡ edição.

Além dos livros destinados ao ensino da leitura, Francisco Vianna teve publicadas séries para o ensino da escrita. Presumivelmente no ano de 1908 ou de 1909, ${ }^{9}$ o autor teve publicada série com um

5 Até o momento, não localizei mais informações a respeito dessa editora.

6 Até o momento, não localizei mais informações a respeito dessa editora.

7 Análise detalhada da Série Leituras Infantis encontra-se em Oriani (2010).

8 Presumivelmente em 1912, Francisco Vianna publicou pela Livraria Francisco Alves (RJ) folheto intitulado Considerações geraes sobre a apprendizagem da leitura, complemento das indicações do prefácio "Aos Professores" da Cartilha da Série Leituras Infantis. Nesse folheto, Francisco Vianna apresenta os fundamentos teóricos a partir dos quais elaborou Cartilha: leituras infantis.

9 Sobre a data de publicação da 1a edição dessa série, localizei informações distintas. Conforme Razzini (2007), a série de cadernos de caligrafia foi publicada "a partir de 1909"; todavia Vidal (1998) afirma que a série foi publicada em 1908. Mediante as duas informações, torna-se impreciso afirmar qual é a 
caderno preliminar e mais seis cadernos de caligrafia, intitulados Novo methodo de caligraphia vertical e editados pela Companhia Melhoramentos (SP), e escreveu e teve publicados outros livros didáticos. Presumivelmente no início da primeira década do século XX, Francisco Vianna também teve publicada série com seis cadernos de caligrafia americana, intitulados Novo methodo de calligrafia americana (inclinada), também editados pela Companhia Melhoramentos (SP).

Além da série de caligrafia, presumivelmente na primeira década do século XX, Francisco Vianna teve publicada série com dez cadernos de linguagem "[...] com gravuras para descripções e composições” (Vianna, 1928, p.4), intitulados Novos cadernos de linguagem, pela Companhia Melhoramentos (SP) e, em apenas um número, Caderno de escripta, livro auxiliar à cartilha publicado pela Francisco Alves (RJ).

No ano de 1901, teve publicado livro para ensino de trigonometria, pela Typographia da Industrial de São Paulo, intitulado Elementos de trigonometria: comprehendendo a resolução de triângulos esphericos. Disposto em 93 páginas, esse livro está dividido em quatro partes, intituladas, respectivamente: "Definição e objecto"; "Taboas trigonometricas"; "Resolução dos triangulos"; e "Exercicios e problemas" (idem, 1901). A proposta do autor é apresentar didaticamente os principais aspectos necessários para compreender e aprender a trigonometria e, especialmente, os triângulos esféricos.

Presumivelmente no ano de 1922, Francisco Vianna teve publicado livro destinado ao ensino de história do Brasil, escrito com a

data correta de publicação dos cadernos. A respeito dessa série de cadernos de caligrafia, localizei informações de que foram publicadas edições novas até pelo menos o ano de 1989, “[...] com tiragens anuais, já na década de 40, superiores a 600.000 exemplares. Segundo informou a editora, até 1997 havia vendido mais de 110 milhões de exemplares" (Heitlinger, 2009, p.43). É também Razzini (2007, p.7) quem informa a intensa circulação desses cadernos: "[...] o material didático que mais teve sucesso foi a coleção de cadernos de caligrafia de Francisco Viana, lançada a partir de 1909 e constantemente reeditada até 1999, um recorde de longevidade". 
colaboração de seu filho Euclides Ribeiro Mendes Vianna, intitulado Pequena historia do Brazil, editado pela Francisco Alves (RJ).

Com 174 páginas, nesse livro, escrito "A pedido dos editores Srs. Paulo de Azevedo \& Cia., proprietários da Livraria Alves, tentei dar, nas poucas paginas que seguem, uma idéa succinta e, tanto quanto possível, fácil e amena, da evolução de nossa Patria" (idem, 1931, p.3), Francisco Vianna apresenta, em seu entender, os principais aspectos relativos à história do Brasil.

Sobre a colaboração de seu filho quando da elaboração do livro, Francisco Vianna (1931, p.3) informa: "Ainda que o plano e a orientação geral sejam exclusivamente meus, utilizei-me principalmente para as leituras, da collaboração de meu filho EUCLIDES RIBEIRO M. VIANNA, que vae revelando grande amor ao estudo de nossa Historia".

No ano de 1930, o autor teve publicado, pela Livraria Francisco Alves (RJ), o livro Modernas directrizes no ensino primário: escola activa do trabalho ou nova. ${ }^{10} \mathrm{~A}$ partir de informações que localizei em base de dados, nesse livro, Francisco Vianna aborda alguns princípios da Escola Nova.

Esse livro resulta de conferências proferidas pelo autor e está dividido em "Apresentação" e três partes, assim intituladas: "As modernas directrizes no ensino primário", "Ilusões, exageros e confusões no ensino primário" e "A conflagração universal apreciada sob o ponto de vista dos meios e dos fins da educação".

Além dos textos publicados sob a forma de livros, Francisco Vianna também teve publicados diversos artigos na Revista de Ensi-

10 Esse livro é indicado na dissertação de Silva (2001), intitulada História de leituras para professores: um estudo da produção e circulação de saberes especializados nos "manuais pedagógicos" brasileiros (1930-1971). Nessa dissertação, Silva (2001) tem como objetivo contribuir para a construção de uma história das leituras destinadas aos professores em formação, analisando, para isso, 44 manuais de ensino que localizou e que foram publicados entre 1930 e 1971. Entre os manuais que Silva (2001) considera terem sido destinados para a formação de professores nesse período está Modernas directrizes no ensino primário: escola activa do trabalho ou nova, de Francisco Vianna, publicado em 1930. 
no, especialmente durante os anos de 1903 e 1904. No âmbito desse periódico, Francisco Vianna teve publicados também alguns de seus poemas, muitos dos quais faziam parte das lições dos livros de leituras da Série Leituras Infantis.

\section{Série Leituras Infantis: proposta de Francisco Vianna para o ensino da leitura}

A Série Leituras Infantis foi escrita a partir de Terceiro livro de leituras infantis. No ano de 1908, esse livro foi publicado juntamente com Primeiro livro de leituras infantis, Segundo livro de leituras infantis e Leitura preparatória.

Nos anos seguintes à publicação desses livros, Francisco Vianna preparava-se para organizar o quarto livro de leituras, quando passou a elaborar a cartilha que integraria a série, que foi publicada presumivelmente no ano de 1912. No ano de 1915, todavia, publicou outra cartilha também integrando a série, que é idêntica à cartilha anterior, sendo acrescido apenas maior grau de detalhamento pedagógico e metódico na sentenciação das lições. Em 1919, esse professor teve publicado Quarto livro de leituras infantis..., completando a série.

Os livros dessa série apresentam a proposta de Francisco Vianna para o ensino da leitura que se inicia com as duas cartilhas na qual é apresentada a leitura como "decifração" e tem continuidade nos livros de leituras que "concretizam" a proposta do autor de ensinar a "leitura corrente" (Vianna, 1925). Considerando esses aspectos, nos livros da Série Leituras Infantis está apresentada uma proposta graduada de ensino da leitura que tem como ponto de partida as sentenças, apresentadas nas cartilhas, as quais são ampliadas e vão se tornando mais extensas nos livros de leitura, como parte da opção do autor pelo método analítico para esse ensino.

Os livros da Série Leituras Infantis estão organizados em uma estrutura que é comum: orientação aos professores, lições e índice. 
As orientações aos professores, de autoria de Francisco Vianna, contêm alguns dos princípios nos quais esse professor baseou-se quando elaborou o livro, além de conter considerações relativas aos procedimentos metodológicos que o professor primário deveria utilizar em sala de aula para que, juntamente com o livro didático, configurasse efetivamente sua proposta para o ensino da leitura.

Essas orientações aos professores, dispostas, geralmente, em três a cinco páginas, precedem as lições, e em apenas alguns exemplares dos livros que localizei as sucedem. Todavia, constatei que esse aspecto se relaciona a uma reorganização editorial, pois, ao comparar as diferentes edições dos exemplares nos quais essas orientações estão remanejadas para o fim do livro, observei que o conteúdo não foi alterado, mas apenas a disposição que se encontra no livro.

Em Cartilha: leituras infantis, além de orientações destinadas aos professores, há também orientações aos pais das crianças que utilizarão a cartilha. Além desse aspecto, como complemento às orientações contidas no prefácio dessa cartilha, Francisco Vianna elaborou um folheto, o qual foi veiculado e divulgado gratuitamente aos professores.

Em Primeiros passos na leitura, as orientações aos professores referem-se à forma com que essa cartilha está organizada complementarmente à Cartilha: leituras infantis, assim como às orientações metodológicas relativas ao ensino da leitura e as lições da cartilha.

As orientações aos professores contidas em Primeiro livro de leituras infantis, Segundo livro de leituras infantis e Terceiro livro de leituras infantis são idênticas e mantidas nas diferentes edições que localizei desses livros. Nessas orientações, Francisco Vianna apresenta as especificidades de sua série de livros de "leitura corrente" (idem, 1909), comparativamente às séries às quais teve acesso até aquele momento. As orientações de Quarto livro de leituras infantis... diferenciam-se das orientações dos outros livros e estão mais direcionadas à finalidade de informar ao professor a importância de ensinar a leitura às crianças a partir de "fatos históricos" (idem, 1923).

As lições dos livros da Série Leituras Infantis são organizadas em histórias nas quais são abordados aspectos relativos às ativida- 
des infantis, a saber: brincadeiras e jogos de crianças, como brincar com bola, com peão, com boneca e pescar; ações comuns ao cotidiano das crianças, como ir à escola, desenhar, colher frutas em árvores, brincar com animais; e situações nas quais há o relacionamento entre os adultos e as crianças, nas quais é explorado, principalmente, o aprendizado que esse relacionamento pode propiciar para as crianças.

Nas lições são apresentados, também, princípios do que seriam ações consideradas adequadas de acordo com as situações apresentadas nas lições, como a importância de não furtar, de não maltratar os animais e de fazer o bem ao colega. Além disso, ao fim das lições de alguns dos livros da série, especialmente os destinados ao ensino inicial da leitura, há sentenças destacadas que têm por finalidade sintetizar moralmente o conteúdo do que foi ensinado e que estão apresentadas sob a forma de poesia, pois, a meu ver, facilitaria a memorização das sentenças por parte das crianças.

As lições dos livros são acompanhadas por gravuras nas quais são abordados os aspectos estudados. Nas lições dos livros da Série Leituras Infantis, as gravuras têm por finalidade congregar os aspectos abordados e permitir que, a partir do questionamento do professor, as crianças consigam elaborar sentenças que descrevam as gravuras e assemelhem-se às sentenças das lições, no caso das cartilhas, e às histórias, no caso dos livros de leituras.

Nas primeiras lições de Cartilha: leituras infantis e Primeiros passos na leitura são apresentadas sentenças mais descritivas, e a gravura ocupa a maior parte da página. À medida que as lições avançam, aumenta gradativamente a quantidade de sentenças, e, por esse motivo, as gravuras e as sentenças passam a dividir equitativamente a página das lições. As últimas lições dessas cartilhas apresentam histórias, e não mais sentenças.

As lições dos livros de leitura não são apresentadas sob a forma de sentenças, mas são histórias, cuja disposição nos livros aumenta progressivamente à medida que as lições avançam e os livros são destinados às classes mais avançadas. Nas lições dos livros de leitura há diversas gravuras, todavia, em menor quantidade e ocupando 
espaço menor, se comparadas à quantidade de gravuras e à disposição por elas ocupada nas cartilhas.

As lições dos livros da Série Leituras Infantis são compostas apenas por histórias, e não há exercícios que as acompanham para "treino" ou "fixação" dos aspectos abordados.

\section{Francisco Vianna e sua produção didática na história do ensino da leitura no Brasil}

Articulando os aspectos gerais relativos aos livros da Série Leituras Infantis à bibliografia de Francisco Vianna, destaco o espaço ocupado por esse professor e sua produção didática para o ensino da leitura no momento em que esta foi publicada.

Nas décadas iniciais do século XX, no âmbito da produção de livros didáticos para o ensino da leitura, segundo Mortatti (2000), alguns professores paulistas tiveram maior destaque, pois aliaram a carreira que construíram como professores aos cargos que ocuparam na administração da instrução pública paulista. Esse é o caso, por exemplo, dos professores Theodoro de Moraes, Arnaldo de Oliveira Barreto, Carlos Alberto Gomes Cardim ${ }^{11}$ e Mariano de Oliveira.

Quando Francisco Vianna disputou espaço no âmbito da produção didática para o ensino da leitura, tinha acumulado experiência profissional como professor primário e secundário e diretor de grupo escolar, todavia, não tinha ocupado cargo de liderança na instrução pública no estado de São Paulo, tendo ocupado cargo de inspetor do ensino secundário no Rio de Janeiro nos anos finais da segunda década do século XX. Nesse sentido, Francisco Vianna acabou desconhecido como professor, autor de livros didáticos e

11 Informações sobre Theodoro de Moraes, Arnaldo de Oliveira Barreto e Carlos Alberto Gomes Cardim encontram-se em textos de Bárbara Cortella Pereira, Vanessa Cuba Bernardes e Franciele Ruiz Pasquim, respectivamente, que integram este livro. Estudos minuciosos sobre esses autores e sua obra foram desenvolvidos por Magnani (1997), Mortatti (2000), Pereira (2009), Bernardes (2003) e Pasquim (2010d). 
administrador da instrução pública, se comparado aos outros professores que mencionei, os quais, no mesmo momento histórico, também tiveram publicados seus livros para o ensino da leitura.

Considero, também, que os professores que atuaram como inspetores escolares tiveram maior contato com os professores primários à medida que, segundo Mortatti (ibidem), realizavam visitas periódicas às escolas e podiam ter conhecimento de aspectos almejados e de algumas das necessidades específicas dos professores primários em relação à aplicação pedagógica do método analítico nos livros didáticos. Francisco Vianna, apesar de ter tido experiência profissional como professor, atuou nas escolas na década final do século XIX e na primeira década do século XX. Quando elaborou os livros da Série Leituras Infantis, situava-se cronologicamente em um momento e buscava soluções de acordo com as referências de que dispunha naquele momento, tanto em relação ao método em si quanto aos aspectos pedagógicos envolvidos na aplicação prática do método.

Presumo que pelo motivo de Francisco Vianna não ter tido uma convivência mais sistemática e perene com os professores primários que pudessem ter-lhe auxiliado no aperfeiçoamento de seus escritos de acordo com as necessidades que surgiam, seus livros tornaram-se menos adequados ao método analítico adotado oficialmente nas escolas públicas paulistas.

Apesar do desconhecimento do professor Francisco Vianna em relação aos outros professores que atuaram no mesmo momento e também tiveram seus livros para o ensino da leitura publicados, a frase "Ivo viu a uva" é bastante conhecida até os dias atuais. Quase sempre associada a uma ideia de ensino "desconexo" da realidade, que não proporciona o envolvimento do aluno para o aprendizado da leitura, a frase carrega, até hoje, o sentido jocoso da cartilha que deve ser evitada em sala de aula. Pensando a respeito da atuação profissional e do desconhecimento de Francisco Vianna, é possível problematizar que uma possível "ausência de realidade pedagógica" tenha tornado a proposta de Francisco Vianna lacunar e tenha sido o motivo de suas frases associarem-se a algo inviável em sala 
de aula. O fato de Francisco Vianna ter tido duas cartilhas idênticas publicadas, sendo a única diferença entre as duas o grau de detalhamento das sentenças nas lições, pode ter significado, também, o "desaprovamento" (ou a não compreensão da proposta) por parte dos professores primários. Essa não apresentação de uma proposta para o ensino da leitura tecnicamente concretizada nos livros pode ter levado Francisco Vianna a detalhar sua proposta e apresentar de modo sistematizado o encadeamento da atividade.

Ainda a respeito da atuação profissional de Francisco Vianna, é possível questionar o interesse desse professor, cuja experiência mais perene foi no ensino secundário - ocupando a cadeira de História Natural no Ginásio Estadual de Campinas e o cargo de inspetor do ensino secundário -, em publicar livros para o ensino da leitura para crianças na fase inicial da escolarização. Teriam sido os poucos anos de sua atividade como diretor de um grupo escolar em Botucatu que, de fato, tenham-no motivado a propor sua série para o ensino da leitura?

Sem a pretensão de apresentar respostas, dadas a extensão e a proposta deste texto, deixo as questões que levantei indicadas para dialogar com o leitor que, assim como eu, tenha se interessado em compreender os aspectos que vão além do que está explicitado pelos autores nos textos e que muitas vezes são necessários para compreender algumas das motivações e escolhas que porventura esses autores tenham tomado e que, como resultado, tenham os direcionado para um caminho e não outro.

\section{Considerações finais}

A proposta deste texto era problematizar de modo articulado a produção escrita de Francisco Vianna, com destaque para o local que esse autor ocupou no âmbito da história do ensino da leitura no Brasil. Busquei ressaltar a atuação representativa do professor Francisco Vianna, a qual ficou "eternizada" nas frases "Ivo viu a uva" e o "Eva viu a ave", isso porque, a partir dos resultados de 
pesquisa de mestrado, pude constatar certo desconhecimento da figura do professor Francisco Vianna, se comparada às frases de sua cartilha, bastante conhecidas na área educacional até os dias atuais.

Para além de propor explicações para essa produção conhecida e para esse autor e professor desconhecido nessa história do ensino da língua e da literatura no Brasil, a proposta deste texto era evidenciar esse autor no âmbito desse "esquecimento" e trazer à tona a história da produção e da contribuição de mais um sujeito da história do ensino da leitura no Brasil.

\section{Referências bibliográficas}

CATANI, D. B. Educadores à meia-luz. Bragança Paulista: Editora da Universidade São Francisco, 2002.

DONATO, H. 100 anos da Melhoramentos: 1890-1990. São Paulo: Melhoramentos, 1990.

HALLEWELL, L. O livro no Brasil: sua história. Tradução de Maria da Penha Villalobos e Lourenço de Oliveira. São Paulo: T. A. Queiroz; Editora da Universidade de São Paulo, 1985.

HEITLINGER, P. A evolução da escrita escolar: manuais e outras propostas. Cadernos de typografia e design. Escolar: uma fonte contemporânea para aprender a escrever e a ler. [S. 1.], n.14, mar. 2009, p.3048. Disponível em: <http://tipografos.net/cadernos/CT14-Escolar. pdf>. Acesso em: 23 dez. 2009.

MAGNANI, M. do R. M. Os sentidos da alfabetização: a "questão dos métodos" e a constituição de um objeto de estudo (São Paulo/18761994). Presidente Prudente, 1997. 389f. Tese (Livre-Docência em Metodologia do Ensino de 1ํGrau: Alfabetização) - Faculdade de Ciências e Tecnologia, Universidade Estadual Paulista.

MORTATTI, M. do R. L. Os sentidos da alfabetização: São Paulo 1876/1994. São Paulo: Editora Unesp, 2000.

Antonio Firmino de Proença, na história da alfabetização no Brasil. In: RAZZINI, M. de P. G. (org.). Antonio Firmino de Proença: professor, formador, autor. São Paulo: Porto de Ideias, 2010, v.1, p.117-39. RAZZINI, M. de P. G. A produção de livros escolares da Editora Melhoramentos na Primeira República. CONGRESSO BRASILEIRO DE CIÊNCIAS DA COMUNICAÇÃO, 30, Intercom, Santos, 
2007. Disponível em: <http://www.intercom.org.br/papers/nacionais/2007/resumos/R1479-2.pdf>. Acesso em: 13 mar. 2009.

ORIANI, A. P. Série "Leituras Infantis" (1908-1919), de Francisco Vianna, e a história do ensino da leitura no Brasil. Marília, 2010. 288f. Dissertação (Mestrado em Educação) - FFC, Universidade Estadual Paulista. SILVA, E. Francisco Furtado Mendes Viana. Revista do professor, [S.1]. ano II, n.11, mai. 1935.

SILVA, V. B. História de leituras para professores: um estudo da produção e circulação de saberes especializados nos "manuais pedagógicos" brasileiros (1930 -1971). São Paulo, 2001. 206f. 2v. Dissertação (Mestrado em Educação) - Faculdade de Educação, Universidade de São Paulo.

VIANNA, F. F. M. Elementos de trigonometria: comprehendendo a resolução de triangulos esphericos. São Paulo: Typographia da Industrial de São Paulo, 1901.

Considerações geraes sobre a apprendizagem da leitura. Complemento das indicações do prefácio "Aos Professores" da Cartilha da série "Leituras Infantis". 3.ed. Rio de Janeiro: Francisco Alves, 1925.

Quarto livro de leituras infantis (Apanhados e factos históricos). 37.ed. Rio de Janeiro: Francisco Alves, 1928. (Série Leituras Infantis). ; VIANNA, E. R. M. Pequena historia do Brazil. 3.ed. Rio de Janeiro: Francisco Alves, 1931.

VIDAL, D. G. Da caligrafia à escrita: experiências escolanovistas com caligrafia muscular nos anos 30. Revista da Faculdade de Educação, v.24, n.1, São Paulo, jan.-jun. 1998. Disponível em: <http://www. scielo.br/scielo.php? pid=S0102-25551998000100009\&script $=$ sci arttext\&tlng=pt>. Acesso em: 15 jan. 2009. 


\title{
7 \\ O PIONEIRISMO DE THEODORO DE MORAES (1877-1956) NA HISTÓRIA DO ENSINO DA LEITURA NO BRASIL ${ }^{1}$
}

\author{
Bárbara Cortella Pereira
}

\section{Introdução}

Nos anos iniciais do século XX, especialmente no estado de São Paulo, o ensino da leitura e escrita a crianças passou por uma importante reforma relativa a seus métodos e processos, iniciada na Escola Normal de São Paulo (ENSP) e na escola modelo, que estiveram à frente desse movimento de renovação no ensino da leitura, assim como alguns de seus "alunos-mestres", que contribuíram para que essa reforma fosse colocada em prática efetivamente.

De acordo com a proposta tornada oficial, os métodos sintéticos deveriam deixar de ser utilizados no ensino da leitura, por serem considerados tradicionais e menos eficientes, e os métodos analíticos simbolizavam a renovação nesse ensino (Mortatti, 2000). Instaurou-se, assim, a polêmica e a disputa em torno dos métodos de alfabetização, considerados por determinado grupo mais eficientes, caracterizando o "segundo momento" da história da alfabetização no Brasil (ibidem).

1 Este texto é resultante de pesquisa de mestrado, desenvolvida com Bolsas CNPq e Fapesp, cujos resultados finais foram apresentados sob a forma de dissertação de mestrado (Pereira, 2009). Com adequações de redação, a dissertação foi publicada em livro (idem, 2013) [N.O]. 
Entre os professores formados por essa importante instituição paulista que contribuíram para essa reforma no ensino da leitura e da escrita está o professor Theodoro de Moraes (1877-1956). Problematizar seu lugar na história do ensino da leitura e escrita em nosso país é meu objetivo neste texto, em que apresento os principais aspectos constitutivos do sentido do livreto A leitura analytica (1909), do documento oficial Como ensinar leitura e linguagem nos diversos annos do curso preliminar (1911) e dos seguintes livros didáticos destinados ao ensino da leitura a crianças: Meu livro: primeiras leituras de accôrdo com o methodo analytico (1909); Meu livro: segundas leituras de accôrdo com o methodo analytico (1910?); Sei lêr: leituras intermediárias (1928); Sei lêr: primeiro livro (1928); e Sei lêr: segundo livro (1930).

\section{Apresentação do professor Theodoro de Moraes}

A contribuição de Theodoro de Moraes para a educação brasileira deve-se a sua profícua atuação profissional em cargos e funções no magistério paulista e a sua produção escrita, que é representativa de seu esforço em disseminar os princípios da assim denominada "pedagogia moderna”, matriz teórica do método analítico para o ensino da leitura.

Theodoro de Moraes nasceu em 1877 e cresceu em um núcleo familiar em que as condições culturais e financeiras eram, no mínimo, diferenciadas, para os padrões das décadas finais do século XIX. Como se sabe, nesse momento histórico, a minoria da população brasileira frequentava a escola primária, e uma parcela bem ínfima, a escola de formação superior. ${ }^{2}$ Provavelmente a formação intelectual e profissional de seu avô (médico) e de seu pai

2 Segundo Azevedo (1958, p.131), “[...] só essa educação de base literária - clássica e de preparação para as profissões de advogados, médicos e engenheiros, conferia aos brasileiros um título, os elevava em dignidade social e ficava sendo ainda o caminho dos cargos importantes". 
(juiz) tenha contribuído para a formação cultural de Theodoro de Moraes. Além disso, sua família valorizava a educação escolar, já que, em meados de 1883, matriculou-o na escola primária de Cuiabá (MT) e, posteriormente, na Escola Neutralidade, em São Paulo (SP), cujas bases do ensino eram o método intuitivo. ${ }^{3}$

Em 1889, Theodoro de Moraes casou-se, na cidade de Amparo (SP), com Joana Correa Rodrigues de Moraes, com quem teve nove filhos, e iniciou sua carreira de professor público nessa mesma cidade, no ano de 1898, como adjunto no Grupo Escolar "Luís Leite", onde lecionou até 1902.

Em 1903, regressou com sua família à capital do estado, para iniciar o curso secundário, na Escola Normal "Caetano de Campos", momento bastante significativo e pouco tranquilo, pois ele renunciou ao conforto de sua vida familiar, profissional e financeira no interior do estado em busca de uma formação mais adequada como professor primário na capital paulistana. Diplomou-se, em 1906, juntamente com outros cinquenta normalistas, tendo-se destacado como um dos mais dedicados de sua turma.

Possivelmente, foi na escola modelo anexa à ENSP, instituição formadora de diferentes gerações de intelectuais, que Theodoro de Moraes teve seus primeiros contatos teóricos e práticos com os pressupostos do método analítico para o ensino da leitura, seja pelo conteúdo das matérias que compunham o programa, seja pelas aulas ministradas pelos professores ou, ainda, por meio das leituras de obras da pedagogia moderna. Inicialmente, Theodoro de Moraes observou e experimentou como aluno-mestre o ensino baseado nos princípios da pedagogia então moderna e, posteriormente, praticou com propriedade todo seu conhecimento como professor.

Em 1907, foi nomeado diretor do Grupo Escolar "Coronel Joaquim de Sales", em Rio Claro (SP), pelo então diretor-geral da Instrução Pública, doutor Oscar Thompson, onde permaneceu por menos de um ano.

3 A respeito do método intuitivo, ver especialmente Valdemarin (2004). 
Em 1908, regressou à cidade de São Paulo, tendo sido nomeado professor na Escola Modelo Isolada do Largo do Arouche, onde permaneceu trabalhando por três anos. Em junho desse mesmo ano, foi nomeado redator efetivo da Revista de Ensino, órgão da Associação Beneficente do Professorado Público de São Paulo, função na qual permaneceu até dezembro de 1909.

Theodoro de Moraes afastou-se da Escola Modelo Isolada do Largo do Arouche em 1910 para assumir o cargo de inspetor escolar, novamente a convite do doutor Oscar Thompson.

Em 1912, foi nomeado professor da nona cadeira da Escola Normal de São Carlos, em São Carlos (SP). Regressou à capital do estado, em 1915, tendo sido nomeado professor de uma escola noturna dessa cidade. Meses depois, essa escola passou a ser denominada Grupo Escolar "Maria José”.

De 1921 a 1928, atuou como diretor do Grupo Escolar "Luís Leite", em Amparo (SP), junto ao qual, no primeiro ano de sua gestão, fundou a Biblioteca Infantil "Olavo Bilac".

Em 1928, Theodoro de Moraes foi nomeado pelo governo do estado de São Paulo para o cargo de inspetor estadual, junto à escola normal livre anexa ao Colégio N. S. do Amparo, tendo sido o primeiro inspetor dessa escola normal. Em 12 de setembro de 1929, foi dispensado dessa função.

Em 1930, Theodoro de Moraes foi nomeado novamente diretor do Grupo Escolar "Luís Leite", onde permaneceu de 10 de novembro daquele ano a 31 de janeiro de 1932. Foi, ainda, assistente técnico e chefe de serviço no Departamento da Educação do Estado de São Paulo, e se aposentou com mais de 36 anos de serviços dedicados à educação.

Conforme mencionado, Theodoro de Moraes iniciou sua carreira de professor público aos 21 anos. Desde suas primeiras atividades profissionais, mesmo antes de se formar na Escola Normal Secundária "Caetano de Campos", demonstrou interesse pelos problemas do ensino, mais especificamente do ensino da leitura pelo método analítico. 
Iniciou sua produção de livros didáticos em 1909, com a publicação da cartilha Meu livro: primeiras leituras de accôrdo com o methodo analytico. Durante as primeiras décadas do século XX, continuou escrevendo cartilhas e livros de leitura baseados no método analítico.

Ao longo de sua carreira no magistério, escreveu oito artigos em periódicos, uma conferência, três documentos oficiais, uma entrevista em jornal, um livreto, dois livros, treze livros didáticos - um caderno de aritmética, cinco cadernos de caligrafia, duas cartilhas e cinco livros de leitura -, uma palestra, três textos de literatura infantil e fez quatro traduções.

O texto mais antigo que localizei data de 1900, e o mais recente, de 1945, sem contar as muitas edições das cartilhas e dos livros de leituras para crianças que tiveram circulação nacional, com mais de um 1.208.000 exemplares impressos apenas pela Companhia Editora Nacional (SP).

\section{Theodoro de Moraes e o método analítico}

De acordo com Magnani (1997) e Mortatti (2000), o método analítico foi implantado na década de 1890 no estado de São Paulo, a partir das primeiras reformas da instrução pública, ${ }^{4}$ experimentado na ENSP, mediante as orientações de miss Browne e dona Maria Guilhermina Loureiro de Andrade, e utilizado em algumas concretizações em livros de leitura. Foi, porém, durante a gestão de Oscar Thompson como diretor da ENSP e como diretor-geral da Instrução Pública do estado de São Paulo, nos anos iniciais do século XX, que esse método foi realmente "institucionalizado" nas escolas primárias paulistas. Theodoro de Moraes teve uma participação efetiva nesse processo de sistematização teórica do método analítico com a publicação do livreto A leitura analytica (1909).

4 Sobre as reformas da instrução pública paulista de 1890-1892, ver Magnani (1997) e Mortatti (2000a) 
Em 1910, um ano após a institucionalização do método analítico para o ensino da leitura, Oscar Thompson escolheu - entre os inspetores escolares em atividade - Miguel Carneiro Júnior, João Pinto e Silva, Theodoro de Moraes e Mariano de Oliveira como responsáveis pela inspeção das matérias de leitura e de linguagem.

Após um ano de inspeção percorrendo diferentes municípios do estado de São Paulo, esses inspetores escolares constataram a falta de uniformização no ensino dessas duas matérias e elaboraram, em conjunto, o documento Como ensinar leitura e linguagem nos diversos annos do curso preliminar (1911).

\section{A leitura analytica (1909) ${ }^{5}$}

No livreto A leitura analytica (1909), tem-se importante síntese das ideias e práticas defendidas por seu autor, relativamente ao método analítico para o ensino da leitura, baseado nas concepções de um ensino moderno, de acordo com os pedagogistas norte-americanos.

Além de divulgar o método analítico e reafirmar as vantagens deste em relação aos métodos sintéticos que até então se empregavam rotineiramente no ensino da leitura, o objetivo de Theodoro de Moraes era fundamentar cientificamente o uso do método analítico para o ensino da leitura. Para tanto, recorreu inúmeras vezes a autores norte-americanos e europeus, a fim de estabelecer um diálogo com o que havia de mais "moderno" na época (Magnani, 1997; Mortatti, 2000). Argumentava, exemplificando, as desvantagens do uso do método sintético para o ensino da leitura e seus prejuízos para a formação da criança, e exaltava as vantagens do método analítico. Afirmava que a unidade de sentido para o ensino da leitura deveria ser o conjunto de sentenças, ou "historietas", e explicava, passo a passo, como esse ensino deveria ser praticado pelos professores, enfatizando a importância das estampas, para o estímulo da

5 Análise detalhada desse livreto, do documento oficial e dos livros didáticos apresentados nos tópicos que seguem encontra-se em Pereira (2009). 
observação e conversação, mediante as "palestras" iniciais com os alunos para que formassem sentenças completas em suas respostas, a utilização frequente do quadro-negro pelo professor e, por fim, o uso de uma cartilha adequada.

O livreto A leitura analytica teve ampla circulação no estado de São Paulo, com repercussão além de seu momento histórico. Em 1909, foi publicado pela Typ. do Diário Official (SP), o que permite inferir que teve também circulação oficial, visto que essa tipografia imprimia documentos oficiais para a Diretoria-Geral da Instrução Pública Paulista. Em março desse mesmo ano, o capítulo I de A leitura analytica foi publicado na Revista de Ensino. Em 1913, a Typ. Siqueira, Nagel \& Comp. (SP) republicou o livreto, e, em 1945, a revista Educação o republicou, em formato de artigo, na seção "Metodologia".

\section{Como ensinar leitura e linguagem nos diversos annos do curso preliminar (1911)}

Também de acordo com Magnani (1997) e Mortatti (2000), o documento Como ensinar leitura e linguagem... ${ }^{6}$ é emblemático das tentativas de implantação do método analítico nas escolas primárias do estado de São Paulo durante a primeira gestão de Oscar Thompson (1909-1911) como diretor-geral da Instrução Pública. Foi utilizado para a orientação dos professores do curso primário para processuar o ensino da leitura e da linguagem pelo método analítico, a fim de uniformizá-lo nas escolas públicas paulistas. Provavelmente, também circulou entre as escolas de formação de professores, entre os administradores escolares e entre os autores de cartilhas e livros de leitura para o ensino pelo método analítico, influenciando-os nas elaborações de propostas e práticas para esse ensino.

Outro aspecto a ser destacado é a permanência desse documento para além do momento histórico em que foi publicado. A repu-

6 Daqui em diante, quando mencionar esse documento oficial, utilizarei a seguinte forma abreviada: Como ensinar leitura e linguagem... 
blicação do documento analisado, em 1918, provavelmente está relacionada com a segunda gestão de Oscar Thompson na condição de diretor-geral da Instrução Pública Paulista, iniciada em 1917, e com suas metas de erradicação do analfabetismo no Brasil, mediante o ensino da leitura pelo método analítico para crianças, jovens e adultos, entre outras iniciativas (Magnani, 1997; Mortatti, 2000).

De qualquer forma, esse documento teve, no momento histórico de sua publicação, importante e pioneira função de uniformização do método de ensino da leitura, assim como o documento oficial Instrucções praticas para o ensino da leitura pelo methodo analytico - modelo de lições, expedido também pela Diretoria-Geral da Instrução Pública, em 1914, e elaborado pelos professores Mariano de Oliveira, Ramon Roca Dordal e Arnaldo de Oliveira Barreto. ${ }^{7}$ Essas instruções dialogam com as do documento oficial Como ensinar leitura e linguagem... para o ensino da leitura pelo método analítico, a partir da "historieta".

\section{Cartilha e livros de leitura de Teodoro de Moraes (1909-1930)}

De acordo com Magnani (1997) e Mortatti (2000a; 2000b), no início do século XX, já havia livros de leituras baseados no método analítico escritos por brasileiros. Mas o diretor da ENSP, Oscar Thompson, em 1904, ao regressar de sua viagem aos Estados Unidos, trouxe consigo a moderna cartilha analítica, Cartilha de Arnold, que foi vertida para o português, em 1907, por Manuel Soares de Ornellas.

Presumo que Oscar Thompson tenha se mostrado entusiasmado com a Cartilha Arnold. Possivelmente esse encantamento

7 Informações sobre Ramon Roca Dordal e Arnaldo de Oliveira Barreto encontram-se em textos de Franciele Ruiz Pasquim e Vanessa Cuba Bernardes, respectivamente, que integram este livro. Estudos sobre esses autores e sua obra foram desenvolvidos por Magnani (1997), Mortatti (2000), Pasquim (2010c) e Bernardes (2003). 
de Thompson pela cartilha norte-americana tenha se devido a sua proximidade com a professora miss Browne e seus ensinamentos da pedagogia norte-americana. Ou talvez sua opção por essa cartilha tenha se devido apenas ao modo de processuar o método analítico para o ensino da leitura, que, no caso de tal cartilha, estava mais próximo da "historieta".

Como já apontaram Magnani (1997) e Mortatti (2000), foi nos moldes da Cartilha Arnold, e baseado em um plano adotado por Thompson, que Theodoro de Moraes elaborou a cartilha Meu livro: primeiras leituras (1909). É possível considerar que a inovação de tal cartilha em relação aos já existentes livros didáticos pelo método analítico de autores brasileiros estava no modo de processuar esse método, pois nessa cartilha o "todo" era considerado o "conjunto de sentenças", ou "historietas".

Outras cartilhas baseadas no método analítico dialogam diretamente com o método defendido e concretizado por Theodoro de Moraes, dentre elas destaco especialmente as cartilhas de Barreto (1909), Cardim (1910?) e Oliveira (1916), por serem recorrentemente citadas ao lado da cartilha de Moraes (1909) e a de Proença ${ }^{8}$ (1926), que, apesar de ter sido publicada em década posterior, também estabelece diálogo com as cartilhas que a antecederam (Magnani, 1997; Mortatti, 2000; 2010a; 2010b; Bernardes, 2003; Oriani, 2010; Pasquim, 2010; Sobral, 2007; Gazoli, 2010).

Um primeiro aspecto a ser destacado é que a Cartilha analytica (1909), de Barreto, foi publicada no mesmo ano em que a cartilha Meu livro: primeiras leituras..., de Theodoro de Moraes, e ambas estavam de acordo com os princípios do método analítico, sendo a "historieta" a unidade de estudo. Sendo assim, qual o motivo de a cartilha de Moraes ter sido considerada a primeira cartilha analítica brasileira, e não a de Barreto? Seria realmente a proxi-

8 Informações sobre Antonio Frimino de Proença encontram-se em texto de Monalisa Renata Gazoli que integra este livro. Estudos minuciosos sobre esse autor e sua obra foram desenvolvidos por Magnani (1997), Mortatti (2000) e Gazoli (2010). 
midade de Theodoro de Moraes com o diretor-geral da Instrução Pública, Oscar Thompson? O fato de Barreto dedicar sua cartilha a "OSCAR THOMPSON, o mais decidido propagandista, no Estado de São Paulo, do ensino da leitura pelo methodo analytico e AO THEODORO DE MORAES, o seu mais fino executor, como preito da mais justa homenagem [...]" seria realmente apenas uma homenagem ou uma estratégia para legitimar sua cartilha de acordo com as prescrições oficiais?

Ao fim do exemplar da 27a edição da Cartilha analytica (1926) é apresentada uma seção intitulada "Modelo de lições", transcrição adaptada do documento oficial Instrucções práticas para o ensino da leitura pelo methodo analytico - modelo de lições (1914) - modelo de lições. Após a explicação dos cinco passos para o ensino da leitura, os autores desse documento oficial aconselham que se passe para a leitura de Meu livro, de Theodoro de Moraes. Segundo Barreto (1926, p.100), "Esta recommendação foi feita porque na occasião era o Meu livro o que mais se aproximava da orientação das Instrucções".

Embora a cartilha de Theodoro de Moraes tenha sido expressamente recomendada em diferentes momentos, é importante destacar que, comparativamente, Cartilha analytica, de Barreto (1909), teve número de edições, permanência e circulação maiores nos estados de Mato Grosso e Minas Gerais.

A Cartilha infantil pelo methodo analytico, de Cardim (1910?), e a Nova cartilha analytico-synthética, de Mariano de Oliveira (1916), aparecem inúmeras vezes citadas como melhores cartilhas analíticas. Em 1918, essas três cartilhas foram eleitas pela comissão avaliadora da diretoria-geral da Instrução Pública paulista dos livros didáticos para o ensino da leitura como as melhores cartilhas analíticas existentes.

A Cartilha Proença, de Antonio Firmino Proença (1926), foi elaborada de acordo com os dois documentos oficiais que normatizaram esse método no estado de São Paulo, portanto, de certa forma,

9 Nesse trecho, Barreto refere-se ao documento oficial Instrucções praticas para o ensino da leitura pelo methodo analytico - modelo de lições (1914). 
dialoga com a cartilha de Moraes, signatário de um desses documentos. No prefácio dessa cartilha, Proença informa que não teve pretensão de originalidade e cita os trabalhos dos professores Theodoro de Moraes, Mariano de Oliveira, Arnaldo de Oliveira, Benedicto Tolosa, Gomes Cardim e Francisco Vianna.

A cartilha Meu livro: primeiras leituras de accôrdo com o methodo analytico, ${ }^{10}$ de Moraes (1909), destinava-se ao ensino inicial da leitura pelo método analítico a alunos do primeiro ano do curso primário, tendo sido indicada e aprovada para a adoção nas escolas públicas do estado de São Paulo e de outros estados brasileiros e utilizada também em escolas particulares. Essa cartilha teve permanência duradoura além do momento histórico de sua primeira edição, tendo contribuído para a alfabetização de diferentes gerações de crianças, por mais de quatro décadas, em diversos estados do país. Essa cartilha foi considerada pelos contemporâneos de Theodoro de Moraes e pelos seus pósteros como a primeira cartilha brasileira processuada de acordo com os princípios do método analítico, como já informei e questionei.

O livro de leitura Meu livro: segundas leituras... destinava-se ao ensino da leitura pelo método analítico aos alunos do segundo ano do curso primário, tendo sido aprovado e adotado pelo governo do estado de São Paulo, de outros estados e escolas particulares. Embora Meu livro: segundas leituras... também tenha permanecido além do momento histórico de sua publicação e tenha formado no mínimo três diferentes gerações de crianças leitoras, não teve a mesma repercussão que a cartilha. Além disso, as menções a esse livro de leitura foram localizadas apenas em lista de livros aprovados e quartas capas de outros livros didáticos.

Principalmente na cartilha Meu livro: primeiras leituras..., a maioria das "historietas" era composta por sentenças interrogativas, como se o autor estivesse dialogando com o aluno sobre a estampa

10 Daqui em diante, quando mencionar esses livros didáticos, utilizarei a seguinte forma abreviada: Meu livro: primeiras leituras... e Meu livro: segundas leituras... 
ou objeto concreto mencionado. No livro de leitura Meu livro: segundas leituras..., além de "historietas" mais complexas, eram apresentados também quinze poemas, ao que tudo indica, uma tentativa do autor de propiciar, já no segundo ano, textos que auxiliassem os alunos a uma leitura expressiva.

Os temas das "historietas" nesses dois livros didáticos também estão de acordo com os princípios teóricos do método analítico, visto que partem do "concreto" para o "abstrato", do universo conhecido das crianças para o desconhecido, e, também de acordo com os princípios do regime republicano, segundo os quais se deveriam preparar as crianças para uma vida sadia, produtiva e, principalmente, dentro dos preceitos morais da época.

Outro aspecto a ser destacado é que Theodoro de Moraes atribuía grande importância às estampas no processo do ensino da leitura de acordo com os princípios teóricos do método analítico e do método intuitivo, pois considerava haver associação direta do pensamento com a forma gráfica. Portanto, as estampas não desempenhavam função meramente ilustrativa das "historietas" do livro didático, mas faziam parte do método analítico, visto que a partir delas, ou até mesmo de objetos concretos, o professor deveria incentivar as crianças a formular sentenças completas sobre que observavam. Por esse motivo, Meu livro: primeiras leituras... e Meu livro: segundas leituras... apresentavam uma quantidade considerável de estampas.

Os diversos exercícios apresentados nesses livros didáticos também desempenhavam função importante no aprendizado da leitura, visto que propiciavam à criança melhor compreensão do processo de análise das sentenças em partes - palavras, sílabas, letras.

Quanto ao público leitor previsto, especialmente da cartilha Meu livro: primeiras leituras..., pode-se afirmar que não era formado apenas pelas crianças do primeiro ano do curso primário, mas também por professores que ainda não tinham conhecimento e informações suficientes para utilizar esse método. Essa cartilha, portanto, foi escrita provavelmente com duas principais finalidades: para o ensino da leitura às crianças pelo método analítico e para 
servir como "modelo" aos professores dos grupos escolares que ainda não sabiam como ensinar a leitura por esse "novo e revolucionário" método.

Após quase duas décadas sem publicar livros didáticos para crianças, em um momento histórico em que, segundo Magnani (1997) e Mortatti (2000), as questões de método deixaram de ser preocupação central para o ensino da leitura, e em outra fase de sua carreira no magistério paulista, com ampla experiência acumulada pelos diferentes cargos que exerceu, Theodoro de Moraes publicou pela Companhia Editora Nacional, em 1928, os livros de leitura graduadas, Sei lêr: leituras intermediárias e Sei lêr: 1ํo livro de leitura, e em 1930, e

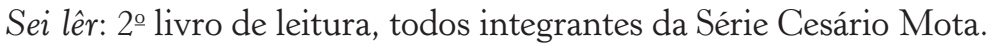

Esses livros de leitura circularam amplamente nas escolas primárias de São Paulo e de outros estados e tiveram também uma permanência para além do momento histórico de publicação das primeiras edições. Os dois primeiros tiveram uma média de cinquenta edições, e o outro chegou a ter 95 edições. Portanto, esses livros de leitura contribuíram para a formação de diferentes gerações de crianças ao longo de quase três décadas.

Diferentemente dos primeiros livros didáticos publicados por Theodoro de Moraes, na década inicial do século XX, os livros de leitura Sei lêr não foram acompanhados de especificações explícitas de que estavam de acordo com o método analítico, pois no momento histórico de publicação de cada um deles não havia mais a necessidade dessa chancela, como avaliam Magnani (1997) e Mortatti (2000). No entanto, pude constatar que eles também foram elaborados de acordo com os princípios do método analítico, defendido por seu autor.

Assim como nos primeiros livros didáticos de Theodoro de Moraes, esses livros de leitura também eram bastante ilustrados. No entanto, pode-se observar uma redução significativa na quantidade de estampas conforme se elevava o ano escolar a que se destinava o livro. Pode-se observar essa redução de estampas, por exemplo, no livro Sei lêr: $2^{\circ}$ livro de leitura, destinado ao terceiro e quarto anos do curso primário. 
As "historietas" aumentaram progressivamente em complexidade estrutural e formal, conforme os alunos avançavam no nível escolar. As temáticas dessas "historietas" continuavam de acordo com o universo da criança, partindo sempre do conhecido para o desconhecido, e com o objetivo de instruí-las de acordo com bons princípios morais, mas não mais estruturadas como em forma de diálogo, com sentenças interrogativas.

Nesses livros de leitura, Moraes também apresenta diversos poemas, intercalados entre as "historietas", introduzindo uma quantidade maior de versos, quadras, provérbios populares, possivelmente para que as crianças exercitassem com mais naturalidade a leitura expressiva sugestionada por esse tipo de texto.

O encerramento da publicação das edições dos livros didáticos de Theodoro de Moraes, em 1956, pode estar ligado a dois fatos principais: a morte de Theodoro de Moraes nesse mesmo ano e a publicação, em 1957, da cartilha Upa! Cavalinho, de Lourenço Filho, ${ }^{11}$ considerada como uma inovação no ensino da leitura e publicada pela Melhoramentos, editora de destaque no ramo de livros didáticos, a partir da década de 1920.

No entanto, Theodoro de Moraes destaca-se pelo pioneirismo, pois, uma vez tornada rotineira, a proposta desse autor para a concretização do método analítico incorporou-se ao saber-fazer de professores e passou a integrar certa tradição, que esse autor repetiu em livros didáticos posteriores, da Série Sei lêr. A proposta da "historieta", porém, lançou raízes na história do ensino da leitura e escrita no Brasil, e sua influência, a partir de então, pode ser constatada nas cartilhas e nos livros de leitura para principiantes publicados ao longo de todo o século XX, e mesmo depois de seus livros terem deixado de ser publicados, como apontam Magnani (1997) e Mortatti (2000a; 2000b)

11 Informações sobre Manoel Bergström Lourenço Filho encontram-se em texto de Estela Natalina Mantovani Bertoletti que integra este livro. Estudos minuciosos sobre esse autor e sua obra foram desenvolvidos por Magnani (1997), Mortatti (2000) e Bertoletti (1997; 2006). 


\section{Considerações finais}

Embora a face mais visível da atuação de Theodoro de Moraes no magistério paulista seja a concretização do método analítico nos livros didáticos destinados ao ensino da leitura a crianças, é importante destacar que esse professor atuou pioneiramente, ao lado do diretor-geral da Instrução Pública, Oscar Thompson, para a institucionalização do método analítico para o ensino da leitura no estado de São Paulo, especialmente mediante a aplicação prática desse método nas aulas ministradas na Escola Modelo Isolada, considerada "modelo" aos professores dos grupos escolares que ainda não sabiam como ensinar a leitura por esse "novo e revolucionário" método; a sistematização dos princípios teóricos desse método no livreto A leitura analytica (1909); a "normatização" desse método no documento oficial Como ensinar leitura e linguagem...(1911); e sua "concretização" em cinco livros didáticos destinados ao ensino da leitura ao curso primário.

Portanto, a "tematização", a "normatização" e a "concretização" do método analítico, defendidas por Theodoro de Moraes, ocupam um lugar pioneiro na história do ensino da leitura no Brasil, com permanência além de seu momento histórico de publicação. As considerações e reflexões apresentadas até aqui permitem, por fim, afirmar que a atuação do professor Theodoro de Moraes e sua produção escrita representam sua incansável e pioneira defesa do método analítico para o ensino da leitura, no âmbito das "tematizações", "normatizações" e "concretizações" relativas a esse ensino, tanto nas primeiras décadas do século XX quanto nas posteriores. A permanência de sua produção escrita por mais de quatro décadas é indicativa, também, da importância desse professor e de sua produção escrita na história do ensino da leitura as crianças no Brasil.

\section{Referências bibliográficas}

AZEVEDO, F. de. A cultura brasileira: introdução ao estudo da cultura brasileira (Tomo terceiro: A transmissão da cultura). 3.ed. São Paulo: Melhoramentos, 1958. 
BARRETO, A. de O. Cartilha analytica. 27.ed. Rio de Janeiro: Franciso Alves, 1926.

BERNARDES, V. C. Um estudo sobre Cartilha analytica, de Arnaldo de Oliveira Barreto (1969-1925). [S. 1]: [s. n.], 2003.

BERTOLETTI, E. N. M. Lourenço Filho e a alfabetização: um estudo de Cartilha do povo e Upa, cavalinho! São Paulo: Editora Unesp, 2006.

BLOCH, M. Apologia da História ou Ofício do historiador. Tradução de André Telles. Rio de Janeiro: Jorge Zahar, 2001.

CARNEIRO, M. et al. Como ensinar leitura e linguagem nos diversos annos do curso preliminar. São Paulo: Siqueira, Nagel \& Comp., 1911.

CATANI, D. B. Educadores à meia luz: um estudo sobre a Revista de Ensino da Associação Beneficente do Professorado Público de São Paulo (1902-1918). Bragança Paulista: Edusf, 2003.

GAZOLI, M. R. O método analítico para o ensino da leitura em "Série de leitura Proença" (1926-1928), de Antonio Firmino de Proença. Marília, 2010. 209f. Dissertação (Mestrado em Educação) - Faculdade de Filosofia e Ciências, Universidade Estadual Paulista.

MAGNANI, M. do R. M. Os sentidos da alfabetização: a "questão dos métodos" e a constituição de um objeto de estudo (São Paulo/18761994). Presidente Prudente, 1997. 389f. Tese (Livre-Docência em Metodologia do Ensino de 1ํo Grau: Alfabetização) - Faculdade de Ciências e Tecnologia, Universidade Estadual Paulista.

MORAES, T. de. A leitura analytica. São Paulo: Typographia do "Diario Official", 1909a.

Leitura analytica. Revista de ensino, São Paulo, ano 8, n.1, p.1720, mar. 1909b.

. Meu livro: primeiras leituras de accôrdo com o methodo analytico.

9.ed. São Paulo: Augusto Siqueira \& Comp., 1920.

Sei lêr: leituras intermediárias. São Paulo: Companhia Editora Nacional, 1928.

Meu livro: segundas leituras de accôrdo com o methodo analytico 5.ed. São Paulo: Typ. Augusto Siqueira \& Comp., 1931a.

. Sei lêr: 1ำ livro de leitura. 2.ed. São Paulo: Companhia Editora Nacional, 1931b.

Sei ler: $2^{\circ}$ livro de leitura. 21.ed. São Paulo: Companhia Editora Nacional, 1936.

Theodoro de Moraes (1877-1956): um pioneiro no ensino da leitura pelo método analítico no Brasil. Marília, 2009. 219f. Dissertação (Mestrado em Educação) - Faculdade de Filosofia e Ciências, Universidade Estadual Paulista. 
MORTATTI, M. do R. L. Os sentidos da alfabetização: São Paulo 1876/1994. São Paulo: Editora Unesp, 2000.

. Educação e letramento. São Paulo: Editora Unesp, 2004.

Antonio Firmino de Proença na história da alfabetização no Brasil. In: Razzini, Márcia de Paula Gregório (org.). Antonio Firmino de Proença: professor, formador, autor. São Paulo: Porto de Ideias, 2010, p.117-39. v.1.

ORIANI, A. P. Série "Leituras Infantis" (1908-1919), de Francisco Vianna, e a história do ensino da leitura no Brasil. Marília, 2010. 288f. Dissertação (Mestrado em Educação) - Faculdade de Filosofia e Ciências, Universidade Estadual Paulista.

PASQUIM, F. Um estudo sobre Cartilha infantil pelo methodo analityco [1910?], de Carlos Alberto Gomes Cardim (1875-1938). Marília, 2010.103p. Trabalho de Conclusão de Curso (Graduação em Pedagogia) -Faculdade de Filosofia e Ciências, Marília, Universidade Estadual Paulista.

PEREIRA, B. C. Um estudo sobre Meu livro (1909), de Theodoro de Moraes. Marília, 2006. 72f. Trabalho de Conclusão de Curso (Graduação em Pedagogia) - Faculdade de Filosofia e Ciências, Universidade Estadual Paulista.

Prescrições para ensinar a ensinar leitura e escrita na Escola Normal de São Paulo: circulação de saberes pedagógicos Brasil/França (18741889). Marília, 2013a. Tese (Doutorado em Educação) - Faculdade de Filosofia e Ciências, Universidade Estadual Paulista.

Theodoro de Moraes na história da alfabetização no Brasil. São Paulo: Editora Unesp, 2013b.

RODRIGUES, J. L. R. Livro jubilar da Escola Normal da Capital: contendo a relação completa dos diplomados de todos os institutos congeneres do Estado de 1876 a 1929. São Paulo: Instituto D. Anna Rosa, 1930.

SOBRAL, P. de O. Um estudo sobre Nova cartilha analytico-synthética (1916), de Mariano de Oliveira. Marília, 2007. 65f. Trabalho de Conclusão de Curso (Graduação em Pedagogia) - Faculdade de Filosofia e Ciências, Universidade Estadual Paulista.

VALDEMARIN, V. T. Estudando as lições de coisas: análise dos fundamentos filosóficos do Método de Ensino Intuitivo. Campinas: Autores Associados, 2004. 


\title{
8 \\ AsPeCTOS DA VIDA, DA ATUAÇÃO PROFISSIONAL E DA BIBLIOGRAFIA DE E SOBRe Antonio Firmino de ProençA $(1880-1946)^{1}$
}

\author{
Monalisa Renata Gazoli
}

\section{Introdução}

Entre os vários professores formados pela Escola Normal de São Paulo (ENSP) está o sorocabano Antonio Firmino de Proença (1880-1946), que, após ter-se diplomado professor nessa importante instituição de formação docente do início do século XX, passou a atuar em instituições escolares paulistas.

Com o objetivo de apresentar e problematizar a contribuição para a história do ensino da leitura e da escrita no Brasil, neste texto destaco dados referentes à vida, atuação profissional e bibliografia de e sobre esse professor, ${ }^{2}$ cuja produção escrita permite situá-lo como representativo do "segundo momento" (Magnani, 1997; Mortatti, 2000a; 2000b; 2010) da história da alfabetização no Brasil. A ênfase em sua produção didática permite considerar que, ainda que ele não tenha defendido enfaticamente o método analí-

1 Este texto é resultante de pesquisa de mestrado, desenvolvida com bolsa Fapesp, cujos resultados finais foram apresentados sob a forma de dissertação de mestrado (Gazoli, 2010a). Com adequações de redação, a dissertação foi publicada em livro (idem, 2011) [N.O.].

2 Referências de textos com informações sobre vida, atuação profissional e produção escrita de Proença estão reunidas em Gazoli (2013). 
tico como o "melhor e mais eficiente" para o ensino das matérias escolares, inclusive para o ensino da leitura, como fizeram vários de seus contemporâneos, ${ }^{3}$ a contribuição de Proença é significativa para a disseminação desse método, visto que apresenta, nos textos de suas autoria, propostas de "concretização" para o ensino pelo método analítico.

\section{Dados biográficos e atuação profissional de Antonio Firmino de Proença}

Filho de Francisco de Proença e de Francisca Amelia de Proença, Antonio Firmino de Proença nasceu na cidade paulista de Sorocaba, em 26 de julho de 1880.

Entre os anos de 1896 e 1990, o professor foi membro do Grêmio Literário "13 de Março”, em Sorocaba, e do Centro Sorocabano de Letras (A. I., 1949, p.23).

Casou-se $\mathrm{s}^{4} \mathrm{com}$ Isaura Ciriaco de Arruda Proença, com quem teve quatro filhos: Alaor de Proença, Aristofanes de Proença, Cleofanes de Proença e Fátima de Proença Nogueira da Silva.

O início de suas atividades de como professor deve-se, segundo o autor do artigo "Um vulto sorocabano", ao fato de que, sendo ele "[...] moço estudioso, concentrado e muito dado aos estudos, não tinha pendores para a carreira comercial, e foi por isso que ao fechar-se a casa em que era auxiliar, rumou para São Paulo para conseguir sua matrícula na Escola Normal da Praça da República”

3 Dentre esses contemporâneos, destaco os professores e inspetores de ensino Theodoro de Moraes, Miguel Carneiro Junior, João Pinto e Silva e Mariano de Oliveira, que não apenas defenderam o método analítico como mais eficiente, mas também elaboraram o documento oficial intitulado Como ensinar leitura e linguagem nos diversos annos do curso preliminar (1911), a fim de uniformizar o ensino da leitura por esse método. Para mais informações sobre esse documento, ver Magnani (1997), Mortatti (2000) e Pereira (2009).

4 Até o momento da redação final deste texto, não foi possível localizar a data em que Antonio Firmino de Proença e Isaura Arruda casaram-se, assim como a data de nascimento e morte de seus filhos. 
(ibidem, p.23). É provável, entretanto, que, sendo Proença de uma família urbana e que dispunha, possivelmente, de algum recurso financeiro, tenha se interessado pelo magistério como forma de ascender socialmente e ocupar lugar de destaque na sociedade paulista.

Ingressou, portanto, como aluno do magistério primário na ENSP, em 1901, tendo-se diplomado em 1904. Foi nessa escola que esse professor teve seus primeiros contatos com os pressupostos do método analítico, tendo sido na escola modelo anexa à ENSP que ele observou, praticou e experimentou o ensino baseado nos princípios da então "pedagogia moderna", sobretudo os que se referiam ao ensino da leitura pelo método analítico.

Após formar-se professor, Proença iniciou, em 1905, suas atividades profissionais como professor da Escola Complementar de Guaratinguetá ${ }^{5}$ e, posteriormente, da Escola Complementar de Piracicaba $^{6}$ (Apontamentos..., 1914).

Em 1913, assumiu o cargo de professor da "13a Cadeira - Métodos e processos de ensino, crítica pedagógica e exercícios de ensino" - na Escola Normal Secundária de São Carlos, ${ }^{7}$ na cidade paulista de mesmo nome (Ozelin, 2006, p.27). Assumiu, no mesmo ano, a função de diretor interino dessa escola, em virtude da licença do diretor efetivo, professor Juvenal Penteado. ${ }^{8}$

5 A Escola Complementar de Guaratinguetá foi instalada em 1903 (Tanuri, 1979, p.105).

6 A Escola Complementar de Piracicaba foi instalada em 1897 (Tanuri, 1979, p.105) e, a partir de 1911, passou a ser denominada Escola Normal Primária de Piracicaba (Tanuri, 1979, p.126).

7 A Escola Normal Secundária de São Carlos foi instalada em 1911 (Tanuri, 1979, p.127).

8 Juvenal Penteado ([18--]-1919) diplomou-se professor pela ENSP e, entre outras atividades, foi diretor da Escola Normal Secundária de São Carlos. Em 1919, ano em que esse professor faleceu, Antonio Firmino de Proença teve publicado um artigo na Revista da Escola Normal de São Carlos no qual o homenageia. Até o momento da redação final deste texto, não localizei outras informações sobre Juvenal Penteado, como data e local de nascimento e escolas nas quais atuou. 
Antonio Firmino de Proença lecionou na Escola Normal Secundária de São Carlos com os professores: Theodoro de Moraes ${ }^{9}$, professor da "9aㅡ Cadeira Geografia e Astronomia"; Juvenal Penteado, professor da "3a Cadeira - Francês e Inglês"; João Lourenço Rodrigues $^{10}$, professor da " 5 a Cadeira - Aritmética e Álgebra"; João Augusto de Toledo ${ }^{11}$ e Carlos da Silveira ${ }^{12}$, ambos professores da "11ํㅡ Cadeira - Psicologia Experimental, Pedagogia e Educação Cívica” (ibidem).

Entre 1916 e 1917, voltou a assumir a direção da Escola Normal de São Carlos; entre 1917 e 1919, voltou, provavelmente, a lecionar como professor da "13a Cadeira"; e entre 1922 e 1927, voltou a dirigir essa escola (D’Ávila, 1946a, p.146).

Atuou também como professor e diretor na Escola Normal Primária de Pirassununga ${ }^{13}$, em Pirassununga (SP) (Apontamentos...,

9 Informações sobre Theodoro de Moraes encontram-se em texto de Bárbara Cortela Pereira que integra este livro. Estudos minuciosos sobre esse autor e sua obra foram desenvolvidos por Magnani (1997), Mortatti (2000) e Pereira (2009) [N. O.].

10 João Lourenço Rodrigues diplomou-se, em 1890, pela ENSP.

11 João Augusto de Toledo (1879-1941) diplomou-se professor pela Escola Complementar de Itapetininga, em 1900, e foi professor em diversas escolas do estado de São Paulo. Em 1925, foi nomeado inspetor-geral de ensino e, em 1930, assistente técnico da ENSP. Em 1932, passou a ocupar o cargo de diretor-geral do Ensino no estado de São Paulo, tendo atuado, posteriormente, como professor assistente na Escola Normal da Praça da República (Melo, 1954, p.637), voltando, assim, a atuar juntamente com o professor Antonio Firmino de Proença, com quem já havia trabalhado na Escola Normal Secundaria de São Carlos (Ozelin, 2006, p.82-3).

12 Carlos da Silveira diplomou-se professor, em 1903, pela Escola Normal da Praça da República. Dentre os cargos que exerceu, destaco: secretário da Escola Normal Secundária de São Carlos (1912), inspetor da Escola Normal Livre do Colégio Santa Inês (1928), redator-chefe da revista Educação (1930), professor de Psicologia e Pedagogia do Curso Normal do Instituto Pedagógico (1930), catedrático de História da Civilização do Instituto de Educação de São Paulo (1933) e membro da Sociedade de Educação de São Paulo, tendo exercido, também, o cargo de vice-presidente (1924) (Melo, 1954, p.596).

13 A Escola Normal Primária de Pirassununga foi instalada em 1911 (Tanuri, 1979, p.127). 
1914), tendo lecionado e dirigido também o Ginásio do Estado de São Paulo, ${ }^{14}$ na cidade de Campinas (SP) (Estrada, 1929, p.310) ${ }^{15}$

Assumiu o cargo de inspetor-geral do Ensino no estado de São Paulo, em 1928, durante a licença do professor Benedicto Maria Tolosa, ${ }^{16}$ tendo sido efetivado em 1929, quando Tolosa aposentou-se (Nomeações, 1929, p.339). Proença, entretanto, atuou como inspetor-geral do ensino somente entre 1928 e 1930, provavelmente porque a "[...] revolução ocorrida em outubro de 1930 ocasionou a troca de todos os cargos públicos considerados de confiança" (Nery, 2009, p.81).

Concomitantemente à sua atuação como professor e diretor de escolas normais, foi membro de duas importantes associações de professores do estado de São Paulo: a Sociedade de Educação, ${ }^{17}$ entre, pelo menos, 1927 e 1931, tendo integrado a comissão "Ensino primário”, com Branca Canto e Mello, ${ }^{18}$ Hortência Pereira

14 O Ginásio do Estado de Campinas, segundo instalado no estado de São Paulo, foi criado em 1896. O primeiro ginásio foi o da cidade de São Paulo, inaugurado em 1894 (Tanuri, 1979, p.77).

15 Não localizei, até o momento da redação final deste texto, a data em que Antonio Firmino de Proença atuou como professor e diretor da Escola Normal Primária de Pirassununga e do Ginásio do Estado de São Paulo.

16 Diplomado, em 1891, pela ENSP, Benedicto Maria Tolosa foi redator efetivo das Comissões de Redação da Revista de Ensino, de 1908 até, pelo menos, 1912, e exerceu vários cargos no magistério público paulista. É autor de Cartilha de alfabetização (1923) (Mortatti, 2000, p.107).

17 "O ciclo de vida da Sociedade de Educação envolve dois períodos, o que ocorreu em função da cessação das atividades da entidade em um tempo intermediário. Dessa forma, classificamos a primeira fase no período que vai de 23 de novembro de 1922, quando ocorre a reunião inaugural, a 20 de novembro de 1924, quando ocorre a última reunião documentada dessa primeira fase. A segunda fase corresponde ao período de 27 de agosto de 1927, quando ocorre a primeira sessão após a reunião de reorganização e vai até, provavelmente, meados de 1931" (Nery, 2009, p.29).

18 Até o momento da redação final deste texto, localizei, sobre Branca de Castro do Canto Melo, apenas as informações de que nasceu na cidade de São Paulo e foi professora de História Geral no Instituto de Educação "Caetano de Campos”, provavelmente nos anos iniciais da década de 1930. 
Barreto, ${ }^{19}$ José de Azevedo Antunes, Renato Jardim ${ }^{20}$ e Zuleika de Barros Pereira; e o Centro do Professorado Paulista (CPP), em 7 de março de 1930, tendo sido o sétimo sócio dessa entidade.

Nos anos iniciais da década de 1930, ${ }^{21}$ Proença assumiu a direção da Escola Normal da Praça da República, na capital do estado de São Paulo, tendo sido o $18^{\circ}$ Diretor a assumir essa função nessa escola. Em 1931, assumiu a direção do Instituto Pedagógico "Caetano de Campos", situado na capital do estado de São Paulo (D’Ávila, 1946b, p.107), função que exerceu até 1933, quando passou a "Professor-Chefe da 5ํㅗㅅão" - "Prática de Ensino" - da Escola de Professores do Instituto de Educação, ${ }^{22}$ também situado na capital do estado de São Paulo. Foi também diretor da escola primária desse instituto (Evangelista, 2002, p.111; 113).

Em 1936, por indicação de Fernando de Azevedo, então diretor do Instituto de Educação da Universidade de São Paulo (USP), Proença afastou-se do cargo de professor e diretor da escola primá-

19 Até o momento da redação final deste texto, não localizei informações sobre Hortência Pereira Barreto, José de Azevedo Antunes e Zuleika de Barros Pereira.

20 Juntamente com M. B. Lourenço Filho e Fernando de Azevedo, Renato Jardim fundou, em 1922, a Sociedade de Educação. Entre 1922 e 1924, foi diretor da ENSP, “[...] quando se afasta para assumir o então recém-criado Tribunal de Contas de São Paulo, tornando-se, depois, Diretor-Geral da Instrução Pública do Rio de Janeiro e ministro de Estado." (Mortatti, 2000, p.183).

21 Até o momento da redação final deste texto, não localizei a data precisa em que Antonio Firmino de Proença passou a atuar como diretor da Escola Normal da Praça da República.

22 O Instituto Pedagógico "Caetano de Campos" passou a ser denominado "Instituto de Educação”, em 21 de fevereiro de 1933. Esse Instituto era constituído, nesse período, pelas seguintes escolas e anexos: escola de professores; escola secundária; escola primária; jardim da infância; e biblioteca. O ensino na escola de professores era distribuído em cinco seções: Educação; Biologia Aplicada à Educação; Psicologia Aplicada à Educação; Sociologia Aplicada à Educação; e Prática de Ensino (Decreto nº 5.846, de 21 de fevereiro de 1933). A respeito dos institutos de educação do estado de São Paulo, ver, especialmente, Labegalini (2005). 
ria do Instituto de Educação e assumiu a direção da escola secundária no mesmo Instituto (ibidem, p.113).

Em 1938, com o fechamento do Instituto de Educação pelo interventor federal do estado de São Paulo, Adhemar de Barros, ${ }^{23}$ Proença assumiu a direção da Escola Normal Modelo da Capital, ${ }^{24}$ na cidade de São Paulo (ibidem, p.171).

Após 35 anos de atuação profissional, em 1939, esse professor aposentou-se, mas continuou atuando no magistério paulista: nos anos iniciais da década de 1940, ajudou a fundar o Ginásio "Caetano de Campos", onde foi professor e diretor (Melo, 1954, p.500).

Após um período atuando como diretor desse ginásio, voltou à cidade de Sorocaba, com problemas de saúde, tendo retornado, em meados da década de 1940, para a cidade de São Paulo, onde faleceu, no dia 4 de abril de 1946, vítima de hipertensão arterial e edema pulmonar (A. I., 1949, p.29).

Após sua morte, recebeu várias homenagens: contemporâneos seus escreveram textos em jornais de notícias e revistas; ruas nas cidades de São Paulo e Sorocaba receberam seu nome; e foi eleito patrono de uma escola estadual na cidade de São Paulo. ${ }^{25}$

\section{Bibliografia de Antonio Firmino de Proença ${ }^{26}$}

Concomitantemente à sua atuação profissional, Antonio Firmino de Proença escreveu vários artigos em revistas pedagógicas de

23 O piracicabano Ademar Pereira de Barros (1901-1969) exerceu vários cargos públicos, entre eles: prefeito da cidade de São Paulo, entre 1957 e 1961, interventor federal no estado de São Paulo, entre 1938 e 1941; e duas vezes governador do estado de São Paulo, entre 1947 e 1951 e entre 1963 e 1966 (Beloch; Abreu, 1984, p.334).

24 A Escola Normal Modelo da Capital passou a denominar-se Escola "Caetano de Campos” em 1939 (Decreto no 10.776, de 12 de dezembro de 1939).

25 A denominação atual dessa escola é Escola Estadual "Professor Antonio Firmino de Proença".

26 As informações sobre a bibliografia de e sobre Antonio Firmino de Proença foram extraídas de Gazoli (2013). 
destaque no momento histórico no qual atuou, assim como vários livros didáticos. Os textos que compõem a bibliografia sobre ele foram citados em escritos de seus contemporâneos e de pesquisadores décadas após sua morte. ${ }^{27}$

Sua produção didática é composta por uma cartilha, Cartilha Proença (1926), e cinco livros de leitura: Leitura do principiante (1926); 1ํo livro de leitura (1926); 2o livro de leitura (1927); 3o livro de leitura (1928); e 4o livro de leitura (1928). Esses seis livros, como informei, integram a "Série de Leitura Proença".

O autor escreveu, ainda, um livro sobre Geografia, intitulado Como se ensina geographia (1928), que integra a Coleção Biblioteca de Educação, ${ }^{28}$ organizada por M. B. Lourenço Filho, ${ }^{29}$ em 1927, pela Companhia Melhoramentos de São Paulo (Weiszflog Irmãos Incorporada). ${ }^{30}$

Dois livros de sua autoria foram publicados por outras editoras: Escreva certo! (1939?), pela Atena Editora, cujo prefaciador é Dácio

27 No instrumento de pesquisa (Gazoli, 2013) encontra-se um total de 187 referências de textos, sendo 110 de textos escritos por Antonio Firmino de Proença e 77 de textos com menções a ele, sua atuação profissional ou produção escrita e/ou citações de seus textos. Ordenei essas referências em duas seções, a saber: Bibliografia de Antonio Firmino de Proença (110 referências); e Bibliografia sobre Antonio Firmino de Proença, sua produção escrita e atuação profissional (77 referências). A primeira seção foi dividida em sete subseções, de acordo com o tipo de texto. Os títulos das subseções e a correspondente quantidade de referências são os seguintes: artigos em periódicos, 31; livros sobre educação, dois; cartilha de alfabetização, dezessete; livros de leitura, 52; livros de Geografia, três; plano de aula, um; e outros, quatro. Essa subseção é composta por referências de textos que não são didáticos, diferentemente das outras subseções, que são compostas unicamente por referências de textos didáticos.

28 A Coleção Biblioteca de Educação foi organizada por M. B. Lourenço Filho para a Editora Melhoramentos e foi publicada entre 1927 e 1970, totalizando 37 títulos. Sobre essa coleção, ver, entre outros, Carvalho e Toledo (2004).

29 Informações sobre Manoel Bergström Lourenço Filho encontram-se em texto de Estela Natalina Mantovani Bertoletti que integra este livro. Estudos minuciosos sobre esse autor e sua obra foram desenvolvidos por Magnani (1997), Mortatti (2000) e Bertoletti (1997; 2006) [N. O.]

30 Para maiores informações sobre esse livro, ver, especialmente, Santos (2005). 
Pires Corrêa; ${ }^{31}$ e Palestras pedagogicas (1930),,32, pela Diretoria-Geral da Instrução Pública do Estado de São Paulo.

Os artigos de Proença foram publicados em quatro revistas pedagógicas, assim distribuídos: doze na Revista da Escola Normal de São Carlos; ${ }^{33}$ dois na revista Excelsior! ${ }^{34}$ treze na revista Educação; e quatro na Revista do Professor. ${ }^{35}$ Nesses artigos, o autor aborda temas como: metodologia do ensino de geografia, metodologia do ensino de Matemática, metodologia do ensino de Ciências e metodologia do ensino de Língua Portuguesa; e homenagem póstuma ao professor Juvenal Penteado ([18--]-1919).

Em seus artigos veiculados na Revista Educação, ao autor apresenta vários planos de aula - "sugestões didáticas" - sobre conteúdos

31 Dácio Pires Corrêa nasceu em Tietê (SP), em 26 de outubro de 1895, e exerceu vários cargos no magistério nacional, entre eles o de diretor-geral da Instrução Pública do estado de São Paulo (Melo, 1954, p.161).

32 Para maiores detalhes sobre esse livro, ver, especialmente, Gazoli (2008).

33 A Revista da Escola Normal de São Carlos foi publicada entre 1916 e 1923 por iniciativa de professores da Escola Normal de São Carlos, poucos anos após a inauguração dessa instituição, em 1911. Nessa revista foram publicados somente artigos inéditos escritos por professores e diretores de escolas normais (Ozelin, 2006, p.6). Os treze fascículos dessa revista são compostos por artigos escritos por 27 colaboradores (Ozelin, 2006, p.49), entre eles Antonio Firmino de Proença, que, concomitantemente às atividades desenvolvidas como professor e diretor na Escola Normal de São Carlos, escreveu doze artigos para essa revista, sendo que quatro deles integram a seção intitulada "Ensino primario".

34 A revista Excelsior! foi uma iniciativa do Grêmio Normalista "Vinte e Dois de Março”, da Escola Normal de São Carlos, desde a criação dessa escola, em 1911, até 1916. A circulação dessa revista era ampla, e sua distribuição, gratuita "[...] para todos os alunos da Escola Normal de São Carlos - todos sócios do grêmio normalista - [...] não há informações sobre vendas ou assinaturas para pessoas externas a essa instituição. [...] além de circular em toda a Escola Normal de São Carlos e da sociedade local, alcançava outras cidades do estado de São Paulo e até mesmo fora dele" (Silva, 2007, p.30).

35 Em 1934 foi publicado o primeiro número da Revista do Professor, órgão do Centro do Professorado Paulista (CPP) fundado em 1930 por Sud Mennucci, também fundador da revista. Esse professor "Contou com grande apoio e incentivo das autoridades governamentais, notadamente do Dr. Amadeu Mendes, Diretor Geral do Ensino do Estado de São Paulo, no ano de 1930" (Santos, 2001, p.30), para a fundação dessa revista. 
dos programas escolares primários. Nos artigos publicados na revista Excelsior! e na Revista da Escola Normal de São Carlos, além de planos de aula, apresenta considerações sobre "lições indutivas, dedutivas e intuitivas" e defende o aprendizado pelo método ativo e direto.

Os artigos escritos por Proença publicados em revistas pedagógicas concentram-se entre 1913 e 1934, sendo que nesse período de 21 anos esse professor não teve artigos publicados em somente nove anos: 1914, 1915, 1924, 1925, 1926, 1927, 1931, 1932 e 1933. Destaco que não localizei artigos de sua autoria publicados tanto entre 1905 e 1912, ou seja, nos anos iniciais de sua atuação como professor, quanto entre 1935 e 1946, anos finais de sua atuação profissional.

Em 1929, publicou seis artigos, enquanto nos demais anos a quantidade variou entre um e quatro artigos. Nesse ano o autor atuava como inspetor-geral do Ensino, como informei, o que talvez explique a facilidade que teve para divulgar suas ideias, considerando-se as possíveis relações que estabeleceu com pessoas influentes desse período, ou mesmo a influência que ele, ocupando esse cargo, exercia sobre seus contemporâneos. Entre 1924 e 1927, provavelmente não tenha escrito artigos porque se dedicava à elaboração de seus livros didáticos, que começaram a ser publicados em 1926 (Cartilha Proença, Leitura do principiante e 1o livro de leitura), 1927 (2o livro de leitura) e 1928 (3o livro de leitura).

O único livro sobre educação que Proença escreveu, intitulado Palestras pedagogicas, foi publicado duas vezes: em 1930, ano em que ocupava o cargo de diretor da Escola Normal da Praça da República, e em 1938, ano em que passou a responder pela direção da Escola Normal Modelo, na cidade São Paulo. Considerando que esse livro foi publicado pela Diretoria-Geral da Instrução Pública do Estado de São Paulo, é possível presumir que a proximidade de seu autor com tal órgão público pode, como no caso dos artigos publicados, ter facilitado a publicação e reedição do livro.

Cartilha Proença foi publicada pela Companhia Melhoramentos de São Paulo (Weiszflog Irmãos Incorporada), com a 1a edição em 1926, e a última, a 84à , em 1955. 
As 52 referências dos livros de leitura que localizei referem-se aos seguintes livros: Leitura do principiante, 1ำ livro de leitura, 2o livro de leitura, 3 livro de leitura e 4o livro de leitura. Cartilha Proença, embora também componha a "Série de Leitura Proença", teve suas referências reunidas por mim, em seção específica, por ter características e finalidades distintas daquelas dos livros de leitura.

Como se ensina geographia teve sua 1a edição publicada em 1928 e a última provavelmente em 1932, sempre pela Companhia Melhoramentos de São Paulo e variando entre 104 e 105 páginas não ilustradas, tendo como prefaciador Lourenço Filho.

Escreva certo!, como informei, é um dos dois livros escritos por Proença que não foram publicados pela Editora Melhoramentos, mas pela Atena Editora (SP), em 1939. Esse livro é composto por setenta páginas não ilustradas e prefaciado por Dácio Pires Corrêa, tendo sido editado pelo menos três vezes. $\mathrm{Na}$ 3a edição, publicada em 1943, o autor apresenta, nas 75 páginas que integram o livro, as regras ortográficas estabelecidas pela Reforma Ortográfica assinada em janeiro de 1943.

Destaco que, na capa desse livro, o nome do professor Antonio Firmino de Proença, para indicação da autoria, é substituído pela expressão "Por um professor". Todavia, por meio de informações apresentadas por Melo (1954), é possível afirmar que esse livro é de autoria do autor aqui estudado.

No livro Palestras pedagogicas, ${ }^{36}$ publicado em 1930, encontram-se versões escritas de duas palestras proferidas pelo professor Proença, na condição de inspetor-geral do Ensino Secundário do Estado de São Paulo. ${ }^{37}$. Essa publicação, que contém 34 páginas, foi editada pelo Departamento de Publicidade da Diretoria-Geral da Instrução Pública do Estado de São Paulo e organizada pelo doutor

36 Palestras pedagogicas é também o título do livro do psicólogo e filósofo norte-americano Willian James (1842-1910), traduzido para a língua portuguesa, em 1917, pelo professor Theodoro de Moraes (1877-1956).

37 Até o momento da redação final deste texto, não foi possível precisar a data em que cada uma das palestras foi proferida. 
Amadeu Mendes, que ocupava, na ocasião, o cargo de diretor-geral da Instrução Pública desse estado.

Por meio de seus artigos em revistas pedagógicas e de seus livros didáticos, Proença auxiliou o trabalho do professor primário em sala de aula, uma vez que em seus artigos são apresentados quase que exclusivamente planos de aulas. É provável que sua atuação como professor da matéria Metodologia e a Prática de Ensino o tenha auxiliado na elaboração de seus artigos e livros didáticos. Ainda que não tenha sido um defensor enfático do método analítico, seus textos apresentam propostas de "concretização" desse método para as várias matérias do curso primário, inclusive para o ensino da leitura.

\section{Bibliografia sobre Antonio Firmino de Proença}

São apresentadas, a seguir, informações referentes a textos nos quais esse professor e/ou sua produção escrita são mencionados ou citados.

Até a finalização do instrumento de pesquisa mencionado, localizei 77 referências de textos com menções a Proença ou citações de sua obra, assim distribuídos: livros, dois; textos acadêmicos, dois; textos em anais de eventos, treze; artigos em periódicos, dois; textos de homenagem póstuma, cinco ; e textos com menções a Proença, sua atuação profissional ou produção escrita e/ou citações de textos seus, 53. As 53 referências que integram a última subseção são distribuídas em quatro outras subseções, tendo obtido a seguinte quantidade em cada uma delas: menções e/ou citações em livros, doze; menções e/ou citações em artigos em periódicos, quinze; menções e/ou citações em jornais de notícias, três; e menções e/ou citações em textos acadêmicos: 23.

Não localizei, com data de publicação até 2007, textos que tratam especificamente da bibliografia de Proença, em especial seus livros didáticos. Localizei, entretanto, textos, a partir de 2007, em que se apresentam resultados da "análise da configuração textual" 
de livros didáticos escritos por esse professor, assim como textos que estão de alguma forma vinculados aos resultados de pesquisas

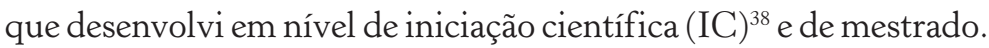

Textos com menções a Proença, sua atuação profissional ou produção escrita e/ou citações de textos seus, entretanto, foram publicados desde 1917 até 2013, com intervalos consideráveis de publicação entre: 1918 e 1927; 1940 e 1945; 1960 e 1967; e 1981 e 1989. A partir do ano de 1990, iniciam-se publicações regulares de textos com menções a Proença, sua atuação profissional ou produção escrita e/ou citações de textos seus, com intervalos de publicação que variam entre um e três anos, sendo que, a partir do ano de 2000, essas publicações ocorrem em todos os anos, impulsionadas pela publicação da pesquisa de Magnani (1997) e Mortatti (2000)

Os textos publicados entre 1917 e 1968 com menções a Proença, sua atuação profissional ou produção escrita e/ou citações de textos seus têm características marcadamente distintas dos publicados após esse período. O conteúdo dos textos publicados entre 1917 e 1968 varia entre: divulgação dos livros didáticos escritos por Proença, com destaque para a eficiência do método analítico neles "concretizados"; e homenagens póstumas a esse professor. Entre os anos de 1974 e 2013, entretanto, os textos com menções a ele, sua atuação profissional ou produção escrita e/ou citações de seus textos apresentam, geralmente, um dos textos que integram a produção didática Proença, com outros livros didáticos publicados no mesmo período, ou em período imediatamente anterior, com o objetivo de compreender o momento histórico no qual esses livros foram publicados.

Foi publicada, em 2010, uma coletânea de textos sobre Proença, organizada por Razzini (2010), na qual são abordados diferentes aspectos da vida profissional e pessoal desse professor. Entre os capítulos dessa coletânea, têm-se: "Bibliografia de e sobre Antonio

38 Este texto também resulta de pesquisa de Iniciação Científica, desenvolvida com bolsa Pibic/CNPq/Unesp, cujos resultados finais foram apresentados sob a forma de Trabalho de Conclusão de Curso (Gazoli, 2007). Artigo com conteúdo semelhante encontra-se em Oliveira (2011b) [N.O.]. 
Firmino de Proença: um instrumento de pesquisa" (Gazoli, 2010b) e "Antonio Firmino de Proença, na história da alfabetização no Brasil” (Mortatti, 2010).

Em 2011, foi publicado o livro intitulado Série de leitura Proença e o ensino da leitura no estado de São Paulo (Gazoli, 2011), no qual são apresentados resultados da análise da configuração textual dos livros que integram a série de leitura escrita pelo professor Proença.

Como informei, localizei treze textos em anais de eventos, e em onze deles abordo a bibliografia de e sobre Antônio Firmino de Proença apresentada anteriormente. Nesses textos, são também apresentadas: "análise preliminar da configuração textual" de Cartilha Proença, do livro Palestras pedagógicas, do livro Leitura do principiante e do 1o livro de leitura; e bibliografia de e sobre Antonio Firmino de Proença.

Ainda de Gazoli (2007b) é o artigo publicado na Revista de Iniciação Científica da FFC-Unesp-Marília, intitulado "Um estudo sobre Cartilha Proença (1926), de Antonio Firmino de Proença", no qual apresento resultados da "análise da configuração textual" da cartilha de autoria do professor Proença.

Localizei, ainda, cinco referências de textos que contêm o que considero homenagem póstuma a Proença. Trata-se de artigos publicados em jornais de notícias e revistas pedagógicas e de verbete em dicionário. Localizei também livreto contendo a programação das atividades organizadas em comemoração ao centenário de nascimento de Proença (1980), realizadas nas cidades paulistas de Sorocaba e São Paulo.

Após a morte de Proença (1946), como informei, vários jornais de notícias e revistas pedagógicas publicaram artigos noticiando seu falecimento, com destaque especial para os professores e representantes de cargos públicos do magistério paulista, e de outros estados, que compareceram em seu funeral.

Entre os textos com menções a Proença, sua atuação profissional ou produção escrita e/ou citações de seus textos publicados entre 1928 e 1932, localizei doze artigos na Revista Educação, escritos por vários professores. 
Já com relação a textos com menções a sua atuação profissional ou produção escrita e/ou citações de seus textos publicados entre 1974 e 2013, localizei 35 referências de textos publicados em livros e textos acadêmicos.

Embora tenha localizado quantidade considerável de textos nos quais são mencionados e/ou citados aspectos da vida, da atuação profissional e/ou da produção escrita de Proença, apenas as pesquisas desenvolvidas por Gazoli, em nível de iniciação científica e mestrado, abordam especificamente a produção escrita desse professor, em especial os livros que integram a série de livros de leitura de sua autoria.

\section{Considerações finais}

Como se pode constatar, a contribuição de Antonio Firmino de Proença para a divulgação do método analítico ocorreu por meio da elaboração e publicação de textos (cartilha, livros de leitura, artigos etc.) nos quais apresenta propostas de "concretização" desse método para o ensino das matérias escolares, sobretudo para o ensino da leitura. Ainda que aparentemente modesta, essa contribuição é significativa, visto que esse professor contribuiu para o ensino da leitura utilizando os pressupostos do método analítico, considerado por ele e por seus contemporâneos como uma possível solução para a superação dos problemas da alfabetização no momento histórico em que atuou, juntamente com o grupo de educadores paulistas que se destacaram nesse momento.

\section{Referências bibliográficas}

A. I. Um vulto sorocabano. Cruzeiro do Sul, Sorocaba, p.3, 29 mar. 1949. Também disponível em: <http://www.exafirmino.com/Dariofotos. htm>. Acesso em: 9 mai. 2007.

APONTAMENTOS sobre o pessoal da escola normal - complementar e modelo, do município de São Carlos. Manuscrito, 1914. 
BELOCH, I; ABREU, A. A. de. Dicionário histórico-biográfico brasileiro: 1930-1983. Rio de Janeiro: Forense Universitária, 1984. v.1.

CARNEIRO, M. et al. Como ensinar leitura e linguagem nos diversos annos do curso preliminar. São Paulo: Siqueira \& Comp., 1911.

CARVAlHO, M. M. C de; TOLEDO, M. R. de A. A coleção como estratégia de difusão de modelos pedagógicos: o caso da Biblioteca de Educação, organizada por Lourenço Filho. In: CONGRESSO BRASILEIRO DE HISTÓRIA DA EDUCAÇÃO, 3., 2004, Curitiba. Anais eletrônicos... Curitiba: Sociedade Brasileira de História da Educação, 2004. Disponível em: <http://www.sbhe.org.br/novo/ congressos/cbhe3/Documentos/Individ/Eixo3/259.pdf $>$. Acesso em: 18 fev. 2009.

CATANI, D. B. Ensaios sobre a produção e circulação dos saberes pedagógicos. São Paulo, 1994. 166f. Tese (Livre-Docência em Didática) Faculdade de Educação, Universidade de São Paulo.

D'ÁVILA, A. História da educação. Educação, v.34, n.48-49, p.146-50, jul./dez. 1946a.

Antonio Firmino de Proença. In: POLIANTEIA comemorativa do 1o centenário do Ensino Normal de São Paulo. São Paulo: Gráfica Bréscia, 1946b, p.107-8.

ESTRADA, A. Proença (Antonio Firmino de). Educação, São Paulo, v.6, n.3, p.310-312, mar. 1929. (Bibliografia Pedagógica)

EVANGELISTA, O. A formação universitária do professor: o instituto de educação da Universidade de São Paulo (1934-1938). Florianópolis: NUP/CED/UFSC; Editora da Cidade Futura, 2002.

GAZOLI, M. R. O método analítico para o ensino da leitura em Cartilha Proença (1926), de Antonio Firmino de Proença. Marília, 2007a. $92 f$. Trabalho de Conclusão de Curso (Graduação em Pedagogia) - Faculdade de Filosofia e Ciências, Universidade Estadual Paulista.

Um estudo sobre Cartilha Proença (1926), de Antonio Firmino de Proença. Revista de Iniciação Científica. Universidade Estadual Paulista, Marília, v.7, n.3, p.246-57, 2007b. Disponível em: <http://www.portalppgci.marilia.unesp.br/ric/viewarticle. php?id=130\&layout=abstract $>$. Acesso em: 22 jul. 2008.

Um estudo sobre Palestras pedagogicas (1930), de Antonio Firmino de Proença. In: SEMINÁRIO INTERNACIONAL: ESCOLA CULTURA, 5, 2008, São Paulo. Anais... São Paulo, p.1-12. CD-Rom.

. O método analítico para o ensino da leitura em "Série de leitura Proença” (1926-1928), de Antonio Firmino de Proença. Marília, 2010a. 
209f. Dissertação (Mestrado em Educação) - Faculdade de Filosofia e Ciências, Universidade Estadual Paulista.

Bibliografia de e sobre Antonio Firmino de Proença: um instrumento de pesquisa. In: RAZZINI, M. de P. G. (Org.). Antonio Firmino de Proença: professor, formador, autor. São Paulo: Porto de Ideias, 2010b, p.223-48.

Série de leitura Proença (1926-1928) e o ensino da leitura no estado de São Paulo. São Paulo: Cultura Acadêmica, 2011. Também disponível em: <http://www.culturaacademica.com.br/catalogo-detalhe. asp?ctl_id=205>.

Bibliografia de e sobre Antonio Firmino de Proença: um instrumento de pesquisa. Marília, 2013. (Digitado).

LABEGALINI, A. C. F. B. A formação de professores alfabetizadores nos institutos de educação do estado de São Paulo (1933 a 1975). Marília, 2005. 315f. Tese (Doutorado em Educação) - Faculdade de Filosofia e Ciências, Universidade Estadual Paulista.

MELO, L. C. Dicionário de autores paulistas. São Paulo: Irmãos Andriolis, 1954.

MAGNANI, M. do R. M. Os sentidos da alfabetização: a "questão dos métodos" e a constituição de um objeto de estudo (São Paulo/18761994). Presidente Prudente, 1997. 389f. Tese (Livre-Docência em Metodologia do Ensino de 1ํ Grau: Alfabetização) - Faculdade de Ciências e Tecnologia, Universidade Estadual Paulista.

MORTATTI, M. do R. L. Os sentidos da alfabetização: São Paulo 1876/1994. São Paulo: Editora Unesp, 2000a.

. Cartilha de alfabetização e cultura escolar: um pacto secular. Cadernos CEDES, Campinas, v.20, p.41-54, 2000b.

Antonio Firmino de Proença, na história da alfabetização no Brasil. In: RAZZINI, M. de P. G (org.). Antonio Firmino de Proença: professor, formador, autor. São Paulo: Porto de Ideias, 2010, p.117-39. v.1.

NERY, A. C. B. A sociedade de educação de São Paulo: embates no campo educacional (1922-1931). São Paulo: Editora Unesp, 2009.

NOMEAÇÕES, Educação, São Paulo, v.7, n.3, p.339, jun. 1929.

OZELIN, J. R. Revista da Escola Normal de São Carlos (1916-1923): a formação do professor. Marília, 2006. 97f. Trabalho de Conclusão de Curso (Graduação em Pedagogia) - Faculdade de Filosofia e Ciências, Universidade Estadual Paulista.

PEREIRA, B. C. Theodoro de Moraes (1877-1956): um pioneiro na história do ensino da leitura pelo método analítico no Brasil. Marília, 2009. 
212f. Dissertação (Mestrado em Educação) - Faculdade de Filosofia e Ciências, Universidade Estadual Paulista.

POLIANTEIA comemorativa do 1o centenário do Ensino Normal de São

Paulo. São Paulo: Gráfica Bréscia, 1946.

PROENÇA, A. F. de. Cartilha Proença. São Paulo: Companhia Melhoramentos de São Paulo (Weiszflog Irmãos Incorporada), 1926. Leitura do principiante: para o 1ำ ano escolar. Ilustrações de Oswaldo Storni. São Paulo: Companhia Melhoramentos de São Paulo (Weiszflog Irmãos Incorporada), 1926. 1o livro de leitura. São Paulo: Companhia Melhoramentos de São Paulo (Weiszflog Irmãos Incorporada), 1926. 20 livro de leitura. São Paulo: Companhia Melhoramentos de São Paulo (Weiszflog Irmãos Incorporada), 1927. 3o livro de leitura, para o 4o ano escolar. São Paulo: Companhia Melhoramentos de São Paulo (Weiszflog Irmãos Incorporada), 1928. . 4o livro de leitura, para o $4^{\circ}$ ano escolar. São Paulo: Melhoramentos, 1948.

RAZZINI, M. de P. G. (org.). Antonio Firmino de Proença: professor, formador, autor. São Paulo: Porto de Ideias, 2010.

SANTOS, F. A dos. A Escola Nova e as prescrições destinadas ao ensino da disciplina de geografia da escola primária em São Paulo no início do século XX. São Paulo, 2005. 181f. Dissertação (Mestrado em Educação: História, Política e Sociedade) - Pontifícia Universidade Católica. SANTOS, M. de L. da S. Revista do professor (1934-1939): contribuições para a formação do pensamento político-pedagógico do magistério primário do estado de São Paulo. Piracibaca, 2001. 117f. Dissertação (Mestrado em Educação) - Faculdade de Educação, Universidade Metodista de Piracicaba.

SILVA, E. C da. O professor ideal em Excelsior! (1911-1916): a revista dos alunos da Escola Normal de São Carlos. São Carlos: Rima, 2007.

TANURI, L. M. O ensino normal no estado de São Paulo: 1890-1930. São Paulo: Faculdade de Educação da USP, 1979. 


\section{9 RenATO Fleury (1895-1980) E O ENSINO DA LEITURA NAS ESCOLAS RURAIS PAULISTAS ${ }^{1}$}

Cyntia Grizzo Messenberg

\section{Introdução}

Visando a compreender um momento da história da leitura, enfoco a contribuição de Renato Fleury (1895-1980) para esse ensino. O objetivo neste texto é mostrar aspectos da vida de Renato Fleury, o lugar que ele ocupou como educador e escritor e suas propostas para o ensino da leitura, destacando sua produção destinada aos alunos que frequentavam as escolas rurais.

Constatei que, apesar de o material didático ter sido destinado aos alunos das escolas rurais, pouco se diferenciava do material didático destinado às escolas urbanas, considerando, principalmente, que foi uma estratégia política e econômica utilizada naquele momento histórico, tanto editorial quanto educacional. De todo modo, a produção didática desse autor dialoga com o "terceiro momento" (Magnani, 1997; Mortatti, 2000) da história da alfabetização no Brasil, sobretudo com o processo de "ruralização" do ensino, característico desse momento histórico.

1 Este texto é resultante de pesquisa de mestrado, desenvolvida com bolsa Fapesp, cujos resultados finais foram apresentados sob a forma de dissertação de mestrado (Messenberg, 2011) [N. O.]. 


\section{Apresentação de Renato Fleury}

A trajetória pessoal de Renato Fleury mostra que, nascido em uma família que pôde lhe proporcionar boas condições de estudos e formação, ele soube fazer uso das oportunidades que teve e ganhou reconhecimento na área educacional naquele momento histórico e político.

Filho de Antônio Gonzaga Sêneca de Sá Fleury e Thereza Guilhermina Grohmann, Renato Sêneca de Sá Fleury nasceu na cidade de Sorocaba (SP), no dia 22 de setembro de 1895. Com apenas 3 anos de idade, perdeu o pai, e permaneceu em Sorocaba até 1902. Com 7 anos de idade, Renato Fleury mudou-se para a cidade de São Paulo, com sua mãe e mais cinco irmãos, e no mesmo ano foi matriculado na escola infantil de Anália Franco, no Largo do Arouche, onde iniciou seus estudos e aprendeu a ler e escrever. Posteriormente, entre 1905 e 1907, estudou na Escola Modelo "Prudente de Morais".

Em 1909, ingressou na Escola Normal de São Paulo (ENSP) e, como aluno do primeiro ano dessa escola, teve um texto publicado na primeira página do jornal Cruzeiro do Sul. ${ }^{2}$

Um ano depois de diplomar-se, Renato Fleury atuou em escolas isoladas rurais, como ocorria com todo recém-formado, para adquirir experiência. Seu primeiro emprego foi em uma escola isolada rural em Santo Antonio da Cachoeira (SP) (atual Piracaia), onde ocupou o lugar de Sud Mennucci. Em setembro de 1913, foi nomeado para reger a primeira escola normal masculina em Sorocaba (SP), no bairro Votorantim.

Entre 1914 e 1915, ministrou aulas na escola isolada rural "Visconde de Porto Seguro", 3 também em Sorocaba, e levava para as aulas

2 Esse jornal sorocabano foi fundado em 1903 e, segundo Luca (2006, p.5), “[...] tinha modernos parques gráficos e uma estrutura editorial e comercial bastante profissionalizada, seguindo modelos, ainda que em escala menor, adotados pelos grandes jornais no país [e contava] com mais de cem profissionais em seus quadros, entre jornalistas, publicitários, gráficos e pessoal administrativo".

3 Essa escola foi criada em 1914 "[...] na região central, com poucas vagas, ocupadas por crianças das famílias de maior prestígio da cidade" (Ferreira; Sandano, 2007, p.175). 
pequenos animais presos, insetos, cobras vivas e vegetais. Levava também máquinas em miniatura e lanternas para fazer projeções. Segundo Silva (1957, p.32), o professor da escola rural deveria “[...] oferecer ensino que [respondesse] às necessidades e às características da vida regional, a fim de adaptar o indivíduo às realidades locais e fixá-lo ao meio, capacitando-o a reagir vigorosamente sobre o mesmo".

Em 1914, com a colaboração do professor Bráulio Wernek e Camargo César, Renato Fleury fundou, em Sorocaba, a revista $A B C$.

No dia 25 de dezembro de 1915, casou-se com Carmem Seabra e, nesse mesmo ano, passou a ministrar aulas no grupo escolar "Antonio Padilha", ${ }^{4}$ em Sorocaba. Presumivelmente com 23 anos de idade, exerceu seu primeiro cargo de diretor, na Escola Normal de São Carlos.

Nos anos subsequentes, atuou em cidades do interior paulista, tendo sido diretor dos ginásios estaduais de Itu e de Ribeirão Preto e delegado de ensino em Araraquara.

De acordo com Fleury (1947, [s.n.]) “[...] em 1925 circunstancias especiais ${ }^{5}$ nos compeliram a declinar de um convite para reorganizar o ensino no [estado de Goiás], feito por intermédio de monsenhor Joaquim Confúcio de Amorim, então vigário do Bispado Goiano [...]".

Após a revolução de 1930 e a consequente implantação do regime ditatorial de Getúlio Vargas, Fleury foi exonerado, em 30 de outubro de 1930, pelo prefeito de Sorocaba, de seu cargo de professor da escola normal e do ginásio de Sorocaba. Passado um ano, prestou concurso, foi aprovado em quarto lugar e, em fevereiro de 1931, assumiu o cargo de professor fiscal na Escola Normal de Sorocaba.

4 Segundo Barreira (2005, p.194), esse foi o primeiro grupo escolar da cidade de Sorocaba, criado em 1896 a partir da reunião das quatro escolas masculinas e das quatro femininas existentes na cidade e que normalmente funcionavam no período da manhã. Ele destaca que "O grupo recebeu o nome de Antonio Padilha, professor e político local que muito lutou para a criação de um grupo escolar na cidade, mas morreu antes de ver esse seu sonho realizado".

5 Até o término da redação deste texto, não localizei nenhuma informação sobre esse grupo escolar. 
Em 1932, foi paraninfo da primeira turma dos normalistas formados por essa escola, e no ano seguinte, além de fiscal da Escola Normal de Sorocaba, Fleury assumiu a chefia da Seção de Educação e ficou responsável por ministrar as aulas de Pedagogia, Psicologia e Didática.

Entre 1932 e 1934, foi redator do semanário A Vida de Sorocaba. Dirigido por Antonio de Alcântara Machado e por Sérgio Milliet (da Academia Paulista de Letras), esse jornal teve 27 números e cessou com a extinção da empresa responsável por sua impressão.

No ano de 1937, foi eleito para ocupar uma cadeira na Faculdade de Ciências e Letras de São Paulo, e nesse mesmo ano foi publicada, no jornal sorocabano Cruzeiro do Sul, uma nota de homenagem a Fleury, na qual é mencionada sua significativa contribuição para a educação no Brasil.

Renato Fleury que soube fazer de sua vida uma preocupação espiritual constante, que soube dar ao seu tempo uma aplicação útil, que soube formar a sua cultura de maneira brilhante, que soube orientar a mocidade que o ouviu e o vem ouvindo de sua cátedra de professor, que soube dar aos pequeninos escolares, com os seus trabalhos pedagógicos, os ensinamentos indispensáveis, não pensou nunca, disso estamos certos, em preparar com as suas atividades, terreno propício para honrarias futuras. (Cruzeiro do Sul, 1937)

Em 1939, tinha 27 livros didáticos publicados, dos quais se vendia uma média de seis edições por ano. Fleury orgulhava-se dos livros que escrevia e, de acordo com Sylvio Almeida (1943 , [s.n.]), apesar de ele não ser de muitas palavras,

[...] se o interlocutor lhe fala nos livros que publicou, então todo se transforma e começa a mostrar a imensa coleção de obras e opúsculos que bastam para uma reputação literária completa, a mesma que lhe arrumou uma cadeira, com muita justiça, na Academia de Ciências e Letras de São Paulo. 
Em 1945, foi presidente da Associação Sorocabana de Imprensa; integrou a comissão julgadora de concurso de contos da União Artística do Interior; ${ }^{6}$ e foi colaborador do Jornal Cruzeiro do Sul, com a coluna "Histórico do Ensino Paulista - O Ensino Normal".

Entre 1933 e 1943, foi colaborador na revista Educação; em 1954, com outros quatro colegas, ${ }^{7}$ foi sócio-fundador do Instituto Histórico, Geográfico e Genealógico de Sorocaba; foi integrante do Instituto Histórico e Geográfico de São Paulo; em 12 de outubro de 1938, ajudou na fundação do Mercado Municipal de Sorocaba; foi integrante da Associação Paulista de Museólogos, no Rio de Janeiro; e fundou o Museu Histórico Municipal de Sorocaba, onde localizei parte considerável dos textos, principalmente notas de jornais, que escreveu.

Fleury aposentou-se em 1942, mas continuou escrevendo livros infantis e artigos para revistas e jornais que circulavam por todos os municípios do estado de São Paulo.

Recebeu, em 1959, da Câmara Brasileira do Livro, o primeiro Prêmio Jabuti ${ }^{8}$ de literatura infantil, com o livro Proezas na Roça. De acordo com Lourenço Filho (in Fleury, 1953, [s.n.]), ${ }^{9}$ que prefaciou o livro em 1953, a história "Pertence a uma espécie de narrativas, que se vão tornando raras, em que o escritor põe muito de sua vida, entretecendo-a, porém de natural e sentida poesia”.

6 Fundada em 5 de junho de 1932, tinha como objetivos: defender o interesse dos escritores, difundir a cultura artística, incentivar o desenvolvimento das artes e letras e formar núcleos em diversas cidades. Disponível em: < http:// www.fundacaoherculanopires.org.br/apostolo-prodigiosadolescente/uai>.

7 De acordo com informações localizadas em nota de jornal de circulação local, os outros sócios - fundadores eram Doraci Amaral, Luiz Almeida Marins, Camargo César e Luís Castanho de Almeida.

8 Em 1959, a ABL instituiu o primeiro Prêmio Jabuti, com o intuito de premiar "[...] editores, escritores, ilustradores, jornalistas e outros profissionais ligados à indústria e comércio do livro" que se destacassem no ano. Na gestão de 1957 1959, Diaulas Riedel oficializou o prêmio e escolheu a figura do jabuti para nomear o prêmio. Disponível em: < http://www.cbl.org.br/jabuti/telas/ historia/>. Acesso em: 30 jul. 2013.

9 Informações sobre Manoel Berström Lourenço Filho encontram-se em texto de Estela Natalina Mantovani Bertoletti que integra este livro. Estudos minuciosos sobre esse autor e sua obra foram desenvolvidos por Magnani (1997), Mortatti (2000) e Bertoletti (1997; 2006) [N. O.]. 
Em 10 de novembro de 1965, faleceu sua esposa, Carmem Seabra Fleury, e passados alguns anos, casou-se pela segunda vez, com Wanda Paracampos, no Rio de Janeiro.

Fundou e dirigiu em Descalvado (SP) o jornal O Progresso; em São Manuel (SP), A Semana; e em sua cidade natal, o Jornal de Sorocaba. Foi, em São Paulo, redator da Revista Nacional. Atuou como jornalista por mais de setenta anos, sendo que, na capital paulista, escreveu para mais de dez, entre eles: Diário da noite ${ }^{10}$ na "Folha da manhã" e "Folha da noite", Diário popular, Jornal do Commercio, Diário de S. Paulo e O Estado de S. Paulo. Ficou conhecido como um "[...] jornalista brilhante, nome de bastante repercussão em São Paulo, e altamente prestigiado nos centros de elite intellectual e mundana, como sóe acontecer aos verdadeiros artistas" (Correio de Sorocaba, 1933, Concurso de contos).

Em 1979, tornou-se membro da Academia Brasileira de Literatura Infantil, ${ }^{11}$ tendo como patrono seu irmão, Luiz Gonzaga Fleury, que também se destacou na área educacional.

Renato Fleury faleceu no dia 16 de janeiro do ano de 1980, no Rio de Janeiro, cidade natal de sua segunda esposa, e foi enterrado no cemitério do Caju. Atualmente há em Sorocaba, sua cidade natal, uma rua, uma escola e uma biblioteca municipal com seu nome.

\section{A contribuição de Renato Fleury como escritor}

A contribuição de Renato Fleury para a educação no Brasil associa-se, entre outras atuações profissionais, a sua extensa pro-

10 Fundado em 1924 pelo professor Léo Vaz. Fleury foi redator entre 1925 e 1928.

11 De acordo com a reportagem "Fleury na Academia Brasileira de Literatura infantil”, publicada em 15 de julho de 1979 no jornal Cruzeiro do Sul, essa academia foi fundada em 21 de março de 1978, no Teatro da Cultura Artística em São Paulo, tendo como principal fundadora Lenyra Camargo Fraccaroli. A sessão solene de instalação foi em 2 de fevereiro de 1979 e teve 21 acadêmicos eleitos no estado de São Paulo e 19 em outros estados do Brasil, entre eles Francisco Marins, Antônio D’Ávilla, Hernani Donato e Castro Borges. Essa eleição foi por mérito e reconhecimento ou por folha curricular. 
dução em diversas áreas do conhecimento, com destaque para: artigos publicados em colunas de jornais que circularam em diversos estados do Brasil; livros de literatura infanto-juvenil, especialmente os livros que integravam a coleção Biblioteca Infantil; e livros que integravam séries de leitura para o curso primário. Além disso, sua contribuição para os movimentos político-educacionais que ocorriam naquele momento histórico e sua atuação em cargos considerados importantes contribuíram para seu reconhecimento por seus contemporâneos.

Em artigo de homenagem aos 25 anos de Renato Fleury como escritor, o responsável pela Typografia São Luiz destaca que, desde a década de 1920, quando teve sua primeira publicação pela Companhia Melhoramentos, até 1946, Renato Fleury publicou 60 “[...] obras pedagógicas, didáticas, literárias e de literatura infantil [...] dos mais variados temas" (Cruzeiro do Sul..., 1946), tornando-se uma

[...] figura distinta de educador e que há muitos anos vem deliciando os nossos leitores com as suas substanciosas colaborações que se dividem pelos mais variados setores denunciando sempre sólida cultura, espírito justo e observador e oportunidade elevada e judiciosa (ibidem).

Desde pequeno, Renato Fleury teve contato com diversos livros de leitura e poesias, o que o estimulou a começar a escrever cedo. Posteriormente, estudou em escolas que tinham renomados professores e teve a oportunidade de se formar na principal escola de formação de professores do estado de São Paulo daquele momento histórico. Subsequente a sua formação, Renato Fleury passou a ministrar aulas em escolas isoladas rurais.

Apesar de a atuação de Renato Fleury em escolas rurais ter acontecido por poucos anos, propiciou-lhe respaldo para que, nos anos seguintes, se tornasse adepto e defensor do ensino nessas escolas, além de formular materiais didáticos específicos para nelas serem utilizados. 
Na série de leitura $\mathrm{Na}$ roça, ${ }^{12}$ que escreveu com destinação específica aos alunos das escolas rurais, a editora destaca que a experiência do autor lhe propiciou formular um material "novo" em relação aos que eram utilizados. Porém, como mencionei, era habitual os professores iniciarem suas atividades práticas nas escolas isoladas rurais, para aquisição de experiência.

Renato Fleury ocupou seu primeiro cargo como diretor em Grupo Escolar de Sorocaba, com 23 anos de idade. Naquele momento, a preocupação com a higiene começava a ganhar destaque entre os educadores, e começaram a ser ministrados cursos para melhorar as condições de funcionamento das escolas primárias, principalmente as localizadas na zona rural.

Como diretor de grupo escolar, Renato Fleury foi selecionado para fazer um curso de higiene no Instituto Soroterápico do Instituto Butantã, onde teve a oportunidade de entrar em contato com um tema então atual e com sujeitos que ocupavam cargos importantes no âmbito político-educacional, entre eles o diretor da Instrução Pública Paulista, Oscar Thompson.

A participação nesse curso pode ter sido a grande porta de entrada de Fleury para o mercado editorial, que trazia benefícios muito mais significativos do que a carreira no magistério paulista.

Poucos anos depois, teve sua primeira publicação pela Companhia Melhoramentos de São Paulo, ao escrever as características de produtos vegetais e minerais brasileiros em quadros ilustrados que formavam a Coleção Riquezas do Brasil. Esses quadros passaram a ser utilizados em escolas de todo o país.

Principalmente na década de 1930, utilizou sua formação e experiência para exemplificar e propor situações que contribuíssem com o movimento de "ruralização" do ensino, que ocorria naquele momento histórico, e empenhou-se em escrever artigos para jornais, livros de leitura e livros de literatura destinados aos alunos das zonas rurais.

12 Para maiores informações sobre essa série de leitura, consultar Messenberg (2012). 
Diante do alto índice de analfabetismo da população brasileira e da constatação que essa população estava, em sua maioria, concentrada nas zonas rurais, a preocupação de educadores relacionada aos interesses de proprietários rurais e políticos passou a ser divulgada no movimento de "ruralização do ensino". Tal movimento passou a ser teorizado e divulgado como forma de despertar nos filhos dos trabalhadores rurais "o amor pela terra", mostrando a importância de permanecerem ali, pois o trabalho rural era fundamental para o desenvolvimento do Brasil.

Esse movimento estava, porém, relacionado com a "Escola Nova”, movimento político-educacional mais amplo que vinha sendo debatido entre os principais educadores brasileiros, que, segundo Ribeiro e Pagni (2003), queriam reformar o "aparelho educacional brasileiro" pela introdução de novas técnicas e concepções pedagógicas.

Proposição pedagógica de cunho eminentemente social, a Escola Nova tinha como horizonte a regeneração da sociedade brasileira e a transformação do país. O indissociável vínculo entre projeto político e projeto educacional articulou questões pedagógicas (pertinente à discussão sobre método e processos de ensino) e questões sociopolíticas, como a ordenação do trabalho, a construção da nacionalidade, a modernização da sociedade e a democratização do país. A mudança da sociedade e da educação mobilizava as aspirações de parte da elite intelectual e política brasileira inconformada com os desvirtuamentos e desatinos da realidade nacional. (Souza, 2009, p.169)

Renato Fleury teve uma produção significativa de artigos em jornais, nos quais, entre outros assuntos educacionais, destacava a necessidade de "ruralizar as escolas". Localizei o total de quatro centenas de artigos desse autor publicados durante sessenta anos de atuação, o que equivale à média de 55 artigos publicados por década.

O maior número de artigos publicados em jornais concentra-se na década de 1930, quando teve publicada a mencionada série 
de leitura $\mathrm{Na}$ roça. Entre as três séries de leitura que escreveu ao longo de sua trajetória profissional, essa foi a única com destinação específica e que teve maior circulação, além de ter sido adotada em todos os estados brasileiros. Os artigos que escrevia circulavam em jornais de diversas cidades brasileiras, como forma de divulgar sua concepção sobre ensino rural e "legitimar" o que havia proposto na série de leitura. Além disso, Renato Fleury destacava a importância de a população permanecer trabalhando na zona rural para que o país se desenvolvesse.

Considerando que, naquele momento histórico, a maior parte da população em idade escolar concentrava-se na zona rural e o ensino da leitura era oferecido a somente uma parcela dessa população, Renato Fleury reforçava a importância de as autoridades educacionais atentarem-se a adaptar o ensino a essa população. Além disso, apesar de o ensino nas escolas rurais ser ministrado em três anos (um ano a menos, quando comparado às escolas urbanas), nem sempre eram completados pelos alunos da zona rural. Isso ocorria devido ao difícil acesso, à estrutura e organização escolar inadequadas e pelo fato de que:

[...] a população nacional acha-se, oitenta por cento, disseminada por considerável extensão do territorio patrio, vivendo e labutando fora das cidades, quase entregue a seu proprio destino, desamparada de si mesma e desajudadda dos poderes publicos [...]

A verdade é que não temos no Brasil a educação popular, no legitimo sentido. Temos, sim, uma deficiente instrucção publica elementar, mais ou menos diffundida e até por vezes algo pomposa nas capitaes e centros urbanos de maior projecção; mas em pequenas cidades, villas e povoados, o que se vê não é ridiculo porque se tinge de collorações sombrias e pungentes. (Fleury, 1938).

Partindo dessas constatações, Renato Fleury enfatizava a necessidade de melhorar o ensino, especificamente das escolas rurais, considerando que os professores que ali atuavam ficavam por tempo provisório, apenas para aquisição de experiência. Enfatiza- 
va, também, a importância de "renovar" o conteúdo, os métodos e os programas de ensino, que eram muito semelhantes aos das escolas urbanas, fazendo com que a escola rural não realizasse sua verdadeira função de "[...] despertar na criança o amor da terra, o sentimento de honra pelo trabalho do solo, dando-lhe apego ao 'seu' pedacinho de chão, educando-a 'ruralmente', apontando-lhe insistentemente o rumo do campo" (idem, 1932).

Considerando que Renato Fleury utilizou os jornais para divulgar a série $\mathrm{Na}$ roça e que neles apresentou suas concepções sobre "ruralização do ensino", é possível afirmar que a publicação da série $\mathrm{Na}$ roça não tinha como finalidade apenas auxiliar o ensino da leitura.

Segundo Souza (2009), entre 1920 e 1930, alguns educadores autointitulavam-se "ruralistas" e passaram a evidenciar os problemas da educação rural fundamentados em movimentos político-educacionais liderados pelos que defendiam a necessidade de reestruturar a educação no Brasil.

Os educadores identificados a esse grupo criticavam o modelo único de escola primária existente no estado, concebido nos moldes de uma escola citadina alicerçada nos valores e na cultura urbana. Essa escola não servia ao homem do campo. Inadequada totalmente ao meio concorria, tão somente, para o êxodo rural. Dessa maneira, eles viam na criação da Escola Rural a possibilidade de fixação do homem no campo. (ibidem, p.150)

Como política editorial, em consonância com essas aspirações político-educacionais, propagadas pelo movimento da Escola Nova, na década de 1930, a preocupação da Companhia Melhoramentos era levar informes úteis ao povo e democratizar a educação por meio da publicação de livros didáticos que atendessem às necessidades da população em idade escolar. Os livros didáticos publicados por essa editora eram majoritariamente aprovados e comprados pela Diretoria da Instrução Pública paulista. 
$\mathrm{Na}$ cartilha e nos livros de leitura que integram a série $\mathrm{Na}$ roça, há aspectos que vão além de métodos didáticos e propostas para o ensino da leitura. Renato Fleury declarou-se defensor da "ruralização do ensino" e, com isso, divulgou princípios pedagógicos defendidos pela Escola Nova. Nesses movimentos político-educacionais, estavam sendo divulgadas concepções que perpassavam a necessidade de reformar o ensino, estando implícitos interesses de uma parcela da população brasileira atrelados aos interesses do Estado.

Além dessa série de leitura, teve publicadas, pela Companhia Melhoramentos, mais uma série de leitura e três cartilhas de alfabetização. Segundo Razzini (2007), entre os autores de sucesso da Melhoramentos está Renato Fleury.

Presumivelmente no final da década de 1930, depois da publicação da série Na roça, Renato Fleury exerceu funções administrativas na Companhia Melhoramentos de São Paulo, ao lado de Lourenço Filho, renomado educador. Sob a orientação de Lourenço Filho, Renato Fleury escreveu e teve publicado mais de quarenta livros de literatura infantil, que integravam a coleção Biblioteca Infantil.

Essa editora era considerada uma das mais importantes naquele momento histórico, com destaque para a produção de livros didáticos e de literatura infantil.

A escolha de Renato Fleury por essa editora para publicar a primeira série de leitura com destinação aos alunos de escolas isoladas rurais vem confirmar como ele soube fazer uso dos contatos e das oportunidades que teve em seu momento histórico, o que contribuiu para que se destacasse no âmbito educacional.

\section{Considerações finais}

A partir dos dados apresentados neste texto, é possível concluir que Renato Fleury contribuiu para a educação no Brasil, principalmente considerando o significativo número de publicações que teve nessa área.

Conforme mencionei na Introdução deste texto, a história da alfabetização é marcada por diferentes propostas que foram feitas 
para o ensino da leitura e da escrita. Para verificar a diferença entre o conteúdo proposto na série $\mathrm{Na}$ roça e cartilhas e livros de leitura que integraram séries de leitura que circularam naquele e nos momentos históricos anteriores, fiz análise comparativa entre exemplares de cartilhas e livros de leitura disponíveis no acervo do Grupo de Pesquisa "História o Ensino da Língua e Literatura no Brasil" (GPHELLB), ${ }^{13}$ que também foram analisados por pesquisadoras desse grupo. Constatei que, apesar de a série $\mathrm{Na}$ roça ter destinação específica aos alunos das escolas rurais, a diferença é insignificante em relação aos livros para alunos de escolas urbanas, confirmando que a autorização, adoção e destinação de uma série de leitura era principalmente uma estratégia política, tanto editorial como educacional.

Renato Fleury, que desde jovem teve oportunidades privilegiadas de estudos e formação, fez uso daquelas e ocupou lugares "estratégicos" no terceiro momento da história da alfabetização no Brasil. Dessa forma, ganhou espaço e reconhecimento necessários para se destacar como professor e escritor.

\section{Referências bibliográficas}

ALMEIDA, A. Galeria de sorocabanos notáveis. Cruzeiro do sul, Sorocaba, 21 fev. 1943.

BARREIRA, L. C. Contribuições da história da Escola Pública Sorocabana para a história da educação brasileira. In: LOMBARDI, J. C.;

13 Refiro-me aqui às cartilhas e aos livros de leitura que foram analisados no âmbito do GPHELLB: Cartilha do povo: para ler rapidamente (1928) e Upa, cavalinho! (1957), ambas de autoria de M. B. Lourenço Filho; Cartilha analytica (1909), escrita por Arnaldo de Oliveira Barreto; Meu livro: primeiras leituras de accôrdo com o método analytico (1909); Meu livro: segundas leituras de accôrdo com o método analytico (1910?); Sei lêr: leituras intermediárias (1928); Sei lêr: primeiro livro (1928); e Sei lêr: segundo livro (1930), todas de autoria de Theodoro de Moraes; Nova cartilha analytico-synthética (1916), escrita por Mariano de Oliveira; Série de leitura Proença (1926-1928), escrita por Antonio Firmino de Proença; Cartilha da infância (188?), escrita por Thomaz Galhardo; Série Leituras Infantis (1908-1919), escrita por Francisco Vianna; e Cartilha infantil pelo methodo analytico [1910?], escrita por Carlos Alberto Gomes Cardim. 
SAVIANI, D.; NASCIMENTO, M. I. M. (orgs.). A escola pública no Brasil: história e historiografia. Campinas: Autores Associados; HISTEDBR, 2005. Coleção Memória da Educação.

CRUZEIRO DO SUL. Jubileu literário do prof. Renato Fleury. Sorocaba, 10 mar. 1937.

O Prof. Renato Sêneca de Sá Fleury foi eleito para a Academia de Ciências e Letras de S. Paulo. Sorocaba, 1937. Com foto.

FERREIRA, V. B.; SANDANO, W. Educação Escolar e movimentos sociais em Sorocaba, no início da República (1889/1920). Revista HISTEDBR On-line, Campinas, n. 27, p. 172-178, set. 2007.

FLEURY, R. S. Questões de ensino - Reajustamento-ruralização. Diário da noite, Sorocaba. 19 abr. 1932.

A escola normal de S. Paulo ha 25 annos. Folha da manhã, São Paulo. 26 jan. 1938.

Proezas na roça. São Paulo: Melhoramentos, 1953.

FLEURY NA ACADEMIA Brasileira de Literatura infantil. Cruzeiro do Sul, Sorocaba, 15 jul. 1979. Com foto.

LUCA, W. A. de. O fortalecimento dos jornais locais e a desconcentração da imprensa no interior de São Paulo: um estudo de caso. In: CONGRESSO IBERCOM, 10, Sevilla-Cádiz, 2006.

MARCílio, M. L. História da Escola em São Paulo e no Brasil. São Paulo: Imprensa Oficial do Estado de São Paulo; Instituto Fernand Braudel, 2005.

MESSENBERG, C. G. A série Na roça, de Renato Fleury, na história do ensino da leitura no Brasil. Marília, 2012. 176f. Dissertação (Mestrado em Educação) - Faculdade de Filosofia e Ciências, Universidade Estadual Paulista.

MAGNANI, M. do R. M. Os sentidos da alfabetização: a "questão dos métodos" e a constituição de um objeto de estudo (São Paulo/18761994). Presidente Prudente, 1997. 389f. Tese (Livre-Docência em Metodologia do Ensino de 1ํ Grau: Alfabetização) - Faculdade de Ciências e Tecnologia, Universidade Estadual Paulista.

MORTATti, M. do R. L. Os sentidos da alfabetização: São Paulo 1876/1994. São Paulo: Editora Unesp, 2000.

RAZZINI, M. de P. G. A produção de livros escolares da Editora Melhoramentos na Primeira República. In: CONGRESSO BRASILEIRO DE CIÊNCIAS DA COMUNICAÇÃO - INTERCOM, 2007, Santos. Anais... Santos, 2007. 
RIBEIRO, E. A; PAGNI, P. Â. Pragmatismo e Escola Nova no Brasil. In: Nuances: estudos sobre educação, ano IX, n.9/10, p. 149-166, jan.-jun. e jul.-dez. 2003.

SILVA, R. I. T. da. A escola primária rural. 2.ed. Rio de Janeiro: Editora Globo, 1957. (Biblioteca Vida e Educação, 10)

SOUZA, R. F de. História da organização do trabalho escolar e do currículo no Século XX: (ensino primário e secundário no Brasil). São Paulo: Cortez, 2008. Biblioteca básica da história da educação brasileira, v.2. 


\title{
10 \\ LOURENÇO FILHO (1897-1970), ESCRITOR DE E SOBRE LITERATURA INFANTIL E JUVENIL ${ }^{1}$
}

\author{
Estela Natalina Mantovani Bertoletti
}

\section{Introdução}

Nos últimos vinte anos, no Brasil, com a ampliação de possibilidades temáticas, de fontes e de critérios de análise de documentos em pesquisa histórica em educação, a atuação e produção escrita de Manoel Bergström Lourenço Filho (1897-1970) têm sido estudadas não somente nos aspectos ligados à educação e psicologia - que prevaleceram até o início dos anos de 1990 na avaliação de sua obra -, mas também em outros aspectos, até então pouco explorados, de sua intensa e decisiva atuação na educação brasileira em sua época e de sua significativa, extensa e importante produção escrita, as quais exerceram influências e permaneceram no âmbito das ideias e práticas pedagógicas ao longo do tempo².

1 Este texto é resultante de pesquisa de doutorado, desenvolvida com bolsa CNPq, cujos resultados finais foram apresentados sob a forma de tese de doutorado (Bertoletti, 2006a). Com adequações de redação, a tese foi publicada em livro (Bertoletti, 2012) [N. O.].

2 Estudos de aspectos pouco explorados da atuação de Lourenço Filho podem ser encontrados em Magnani (1997a; 1997b), Mortatti (2000; 2001) e Bertoletti (1997; 2006a; 2006b; 2012). 
Neste texto, busco evidenciar um desses aspectos da atuação e produção escrita de Lourenço Filho, pouco explorado até então: o de escritor de e sobre literatura infantil e juvenil. Para isso, a partir de aspectos de formação e atuação desse intelectual ao longo de sua vida, destaquei aspectos ligados à literatura e literatura infantil e juvenil $^{3}$ e ressaltei, dentro de sua faceta como escritor, dados gerais dessa produção.

É importante mencionar que esse aspecto da obra de Lourenço Filho esteve relacionado ao ensino de leitura e escrita, uma vez que seus escritos de e sobre literatura infantil e juvenil estavam contidos em um projeto maior de educação e cultura, no qual seu pensamento a respeito desse ensino teve destaque e repercussão, caracterizando o "terceiro momento" (Mortatti, 2000) da história da alfabetização no Brasil. Nesse terceiro momento, prevaleciam as discussões acerca de aspectos psicológicos envolvidos no processo, em detrimento de aspectos linguísticos e pedagógicos, havendo certa relativização dos métodos e ênfase no nível de maturidade biofisiológica para aprendizagem inicial da leitura e da escrita, conforme proposto por Lourenço Filho (Magnani, 1997a; 1997b; Mortatti, 2000).

\section{Formação e atuação de Lourenço Filho}

Manoel Bergström Lourenço Filho nasceu em 10 de março de 1897, na então vila de Porto Ferreira (SP). Seus primeiros contatos com a literatura vieram pela tradição oral, como o próprio Lourenço Filho atesta em entrevista à revista Formação, em 1940.

Meu avô possuía uma cultura acima da mediana. Na sua bagagem de imigrado trazia algumas dezenas de livros e um violino que tocava com maestria. Na pequenina cidade, onde foi fixar-se, inquietava-o a falta de uma escola primária. E, assim, embora não

3 A produção de Lourenço Filho de e sobre literatura infantil e juvenil foi reunida em Instrumento de Pesquisa (Bertoletti, 2006c). 
dominasse ainda de modo perfeito a língua do país, reunia, aos domingos, as crianças da vizinhança e procurava ensinar-lhes a leitura. Lembro-me de ter aos seis anos tomado parte nesses amáveis exercícios, que meu avô entremeiava com a narrativa das "sangas" de sua terra e de suaves canções suecas ao violino... (Lourenço Filho, 1940, p.6, destaques meus)

Depois dessa "primeira escola", o acesso formal à leitura e à escrita veio, primeiramente, de aulas particulares, ministradas por um antigo escrivão de fazenda "[...] que perdera o emprego e a quem aconselharam abrisse uma 'escola', a três mil réis mensais por cabeça” (ibidem, p.6), e, depois, em aula municipal, regida por mestre leigo. Após poucos meses, Lourenço Filho passou para uma escola estadual, então recentemente criada, regida pelo professor diplomado Ernesto Alves Moreira. ${ }^{4}$ Mais tarde, prosseguiu seus estudos primários na cidade vizinha, Santa Rita do Passa Quatro, com este último professor, a quem Lourenço Filho atribuiu grande influência por sua opção pelo magistério (ibidem).

A passagem do aluno Lourenço Filho da aula municipal para a escola estadual, como se pode inferir por seu depoimento, parece estar ligada a uma de suas primeiras produções escritas: o jornalzinho $O$ Pião, do qual Lourenço Filho, aos 8 anos e 4 meses, era "chefe", "único redator" e "typographo" e que pretendia ser "Orgam critico, dedicado aos alumnos das escolas d'esta villa" (idem, 1905, n.p.).

O professor estadual abriu a sua escola já nos meiados do ano e, sabendo que a aula municipal estava superlotada, foi ao nosso mestre e pediu os alunos excedentes. "Dê-me mesmo os piores, disse êle, em voz alta. Hei de arranjar-me com esses mesmos, de qualquer geito." [...] Mal se havia êle retirado, o nosso velho mestre se dirigiu a nós, de maneira solene e disse que, naquele mesmo dia, queria se ver livre dos "maus elementos". Pagaríamos com o novo

4 Não obtive, até o momento, mais informações sobre esse professor. 
mestre tudo quanto tínhamos feito até ali! E começou a escolha. O primeiro a ser destacado foi um rapaz de dezesseis anos, forte, desabusado, que mal andava no primeiro livro de Felisberto de Carvalho. O terceiro fui eu. "O senhor, também! Ponha-se ali na fila para não andar mais com histórias de jornalzinho!..." Eu tinha oito para nove anos, uma prodigiosa imaginação, que não se compadecia com os problemas de aritmética que o nosso mestre nos dava, sobre côvados, varas e canadas... Meu pai havia instalado uma tipografia, anexa à sua casa comercial e me permitira imprimir um jornalzinho, a que o meu mestre atribuía o meu desinteresse pela contas... De seu julgamento, não tenho dúvida: era dos piores alunos em sua escola. (idem, 1940, p.7, destaques no original)

Os estudos de Lourenço Filho prosseguiram, com todas as dificuldades de um aluno pobre, até obter o diploma de normalista, em 1914, na Escola Normal Primária de Pirassununga (SP). No ano seguinte, passou a exercer o magistério, em Porto Ferreira, no grupo escolar então recentemente criado. Lourenço Filho sentia, entretanto, que, embora amasse sua profissão, sua "[...] cultura era muito deficiente mesmo para ensinar crianças" (ibidem, p.9), por isso, em 1916, mudou-se para a cidade de São Paulo, a fim de cursar a escola normal secundária na Escola Normal de São Paulo (ENSP), cujo curso concluiu no ano seguinte.

Nessa época, a opção pelo magistério consolidou-se em Lourenço Filho pela influência, especialmente, de Antonio de Sampaio Dória, ${ }^{5}$ como se pode verificar no depoimento que segue:

[...] Na Escola Normal Secundária de São Paulo, defrontei professores como Oscar Thompson e Antonio de Sampaio Dória. Este, sobretudo, ensinando psicologia e pedagogia, exercia grande influência sobre os alunos. Eu conhecia Compayré e Rayot... As

5 Antonio de Sampaio Dória ingressou na Escola Normal de São Paulo em 1914, assumindo a cátedra de Métodos e Processos de Ensino, Crítica Pedagógica e Exercícios de Ensino. A esse respeito, ver, especialmente, Carvalho (1999). 
doutrinas e técnicas modernas eu as havia entrevisto apenas por um livro de Farias de Vasconcelos. Sampaio Dória nos apresentava William James, Clàparede, Van Biervliet, Ribot, Parker... E não era só a matéria: era o método. Sampaio Dória transformava todas as aulas em "seminário", com discussões, pesquisas, experiências. Comunicava, ademais, aos alunos, a convicção de que o Brasil só poderia ser construído pela educação. (ibidem, p.10)

Em 1920, Lourenço Filho foi designado professor substituto de Pedagogia e Educação Cívica na escola normal primária anexa à ENSP. Isso se deu porque o professor efetivo, Roldão Lopes de Barros, fora indicado para substituir Sampaio Dória, na escola normal secundária, enquanto este estivesse exercendo a função de diretor-geral da Instrução Pública de São Paulo. No ano seguinte, Lourenço Filho foi nomeado professor de Psicologia e Pedagogia da Escola Normal de Piracicaba, quando fundou a Revista de Educação. Nesse mesmo ano, casou-se com a professora Aída de Carvalho, com quem teve dois filhos: Ruy e Márcio.

No período de 1915 a 1921, Lourenço Filho teve seus primeiros escritos publicados. Eram textos de cunho social, pedagógico e literário. ${ }^{6}$ Esses textos foram o resultado da intensa atividade jornalística de Lourenço Filho, a qual lançou seu nome em nível nacional mediante a divulgação de suas ideias modernas em relação a seu tempo. Essa atividade jornalística também propiciou a ele o convívio com grandes redatores, repórteres e colaboradores de jornais, como Júlio Mesquita, Júlio Mesquita Filho, Nestor Rangel Pestana, Plínio Barreto e José Bento Monteiro Lobato (Monarcha;

6 Segundo Lêda Lourenço (2001), nora de Lourenço Filho, a análise desses artigos permite identificar algumas ideias que refletem as preocupações educacionais, bem como o pensamento social e político da época em que foram escritos. As ideias presentes nesses primeiros textos, ainda segundo a autora, continuaram a ser trabalhadas nos escritos posteriores de Lourenço Filho e foram ora ampliadas, ora reformuladas, mas sempre estiveram relacionadas a seus primeiros textos. A esse respeito ver, sobretudo, Lourenço (2001). 
Lourenço Filho, 2001), realizando, na prática, um bom curso de jornalismo, que, à época, não existia.

Nesse período, colaborou com a revista Vida Moderna (SP) produzindo textos de literatura e de crítica literária -, com a $R e$ vista do Brasil (SP) e com os jornais Jornal do Commercio (SP), O Commercio de S. Paulo (SP), A Folha (Porto Ferreira-SP), Jornal de Piracicaba (Piracicaba-SP), O Estado de S. Paulo (SP), entre outros, produzindo artigos de cunho político-pedagógico.

Na Revista do Brasil, tornou-se secretário de Monteiro Lobato, com quem passou a formar, com Fernando de Azevedo e Anísio Teixeira, o que Lobato chamou de uma "irmandade", com obrigações de ação e necessidade de se fazerem combativos (Lourenço Filho, 1929). A partir dessa época, Lourenço Filho demonstrou grande preocupação com a leitura e sua disseminação. A leitura tornou-se seu instrumento de trabalho, por isso Lourenço Filho empenhou-se em tematizá-la em seus estudos e escritos, em normatizar seu ensino ao ocupar cargos administrativos e em concretizá-la em livros didáticos e de literatura infantil, resultando em uma numerosa e variada produção escrita.

Em 1922, Lourenço Filho foi convocado para ir ao estado do Ceará, a fim de reorganizar o ensino público, onde permaneceu até dezembro de 1923. Viajando pelo interior do Ceará para recenseamento escolar, encontrou-se com o padre Cícero Romão Batista, então prefeito de Juazeiro, cujo desinteresse e proibição impediram o cadastro escolar naquela cidade. Segundo Monarcha (2001), a realidade do sertão nordestino, a situação do sertanejo e a figura do padre Cícero causaram impacto na "sensibilidade ilustrada" de Lourenço Filho, que, mais tarde, registrou essa experiência em dez artigos, publicados de novembro de 1925 a agosto de 1926 no jornal O Estado de S. Paulo e, depois, no livro Joaseiro do Pe. Cícero (1926). Com esse livro, Lourenço Filho recebeu o prêmio Ensaios, em 1927, e passou a ocupar a cadeira no 32, da Academia Paulista de Letras, em 1929, em substituição a Ezequiel de Paula Ramos (1846-1905). 
Nessa noite, o escritor Lourenço Filho, ao receber com os demais novos o alto título de pertencer à Academia Paulista de Letras, ocupando a cadeira n. 32, passava a figurar entre os homens de letras do país. (Lourenço Filho, 1997, p.43, grifos meus)

Ao retornar do Ceará, em 1924, Lourenço Filho voltou a Piracicaba e passou a desenvolver estudos em Psicologia, aprofundados e expandidos no ano seguinte, em São Paulo, quando, como professor de Psicologia e Pedagogia na escola normal secundária, realizou pesquisas referentes especialmente à hipótese de um nível de maturidade como pré-requisito indispensável para o aprendizado da leitura e da escrita, das quais derivou o livro Testes $A B C$ - para a verificação da maturidade necessária ao aprendizado da leitura e da escrita (1934). ${ }^{7}$

Em 1926, respondeu a um inquérito sobre os problemas da instrução pública promovido pelo jornal O Estado de S. Paulo e coordenado por Fernando de Azevedo. ${ }^{8}$ Em sua resposta, Lourenço Filho criticou a escola tradicional " [...] individualista, verbalista, intelectualista e anarquisadora da mente e do caráter" (idem, 1957, p.103) e divulgou suas ideias "modernas" a respeito da escola primária, como escola nova, inspirada em novos ideais.

Ainda em 1926, assumiu, em substituição a Arnaldo de Oliveira Barreto (1869-1925), ${ }^{9}$ a organização da coleção Biblioteca Infantil, editada pela Companhia Melhoramentos de São Paulo. ${ }^{10}$

7 Análise da configuração textual desse livro de Lourenço Filho encontra-se em Magnani (1997a; 1997b) e Mortatti (2000).

8 As respostas ao inquérito foram também publicadas em forma de livro, organizado por Fernando de Azevedo, sob o título A educação na encruzilhada, cuja primeira edição é de 1937.

9 Arnaldo de Oliveira Barreto organizou a coleção Biblioteca Infantil entre 1915 e 1925. Informações sobre esse autor encontram-se em texto de Vanessa Cuba Bernardes que integra este livro. Estudos minuciosos sobre esse autor e sua obra foram desenvolvidos por Magnani (1997), Mortatti (2000) e Bernardes (2003) [N. O.].

10 Análise da revisão feita por Lourenço Filho de O patinho feio, de H. C. Andersen, na coleção Biblioteca Infantil, encontra-se em Menin (1999). 
E dois anos depois, preocupado com o ensino da leitura e da escrita para as "massas", teve publicada Cartilha do povo - para ensinar a ler rapidamente, cartilha destinada à alfabetização de crianças e adultos, publicada pela Companhia Melhoramentos de São Paulo e que alcançou mais de duas mil edições ao longo de sua trajetória editorial. ${ }^{11}$ Nessa editora, Lourenço Filho assumiu a tarefa de consultor editorial, emitindo pareceres sobre originais de livros para crianças: didáticos e de literatura infantil.

Em 1925 [a Companhia Melhoramentos de São Paulo] agregou uma das mais consolidadas reputações da Escola Nova, o professor Manoel Bergstrõm Lourenço Filho. [...]

Lourenço Filho aproximara-se da empresa chamado para renovar a Biblioteca Infantil, atualizando a linguagem, principalmente. Assumiu a tarefa de consultor editorial, emitindo pareceres sobre originais didáticos e para a infância. Ao longo de algumas décadas viria a emitir quase 30.000 pareceres.

Organizou (1927) a Biblioteca de Educação, com a finalidade de introduzir no país correntes de filosofia da educação elaboradas em outros centros de debates. Preparou os 35 títulos da Biblioteca, assinou traduções, adaptações e revisões de texto. Hasso Weiszflog, que acompanhou os trabalhos daquele educador, afirmou haver sido ele um "segundo ego da editora". Esta, outorgou-lhe, em 1987, o Prêmio Lourenço Filho aos seus autores mais distinguidos pela preferência do leitorado. [...]

Lourenço Filho editara a Cartilha do Povo. Fiel à proposta avançada no título, a cartilha alavancou durante mais de quarto de século os esforços oficiais, particulares, gremiais, religiosos e partidários no sentido da alfabetização massiva. Em 1990, a Cartilha do Povo superou 2.200 edições somando 20 milhões de exemplares. (Donato, 1990, p.87-8,destaques no original)

11 Estudo detalhado dessa e da cartilha Upa, cavalinho!, de Lourenço Filho, encontra-se em Bertoletti (1997; 2006b). 
Segundo Carvalho e Toledo (2004), como editor, Lourenço Filho assumiu uma posição de "gestor" de política de reforma escolar e de profissional engajado no movimento de renovação educacional brasileiro. Ainda conforme essas autoras, em relação à coleção Biblioteca de Educação, ${ }^{12}$ a "etiqueta Lourenço Filho" funcionava como depósito de legitimação do empreendimento editorial, podendo mobilizar uma rede de autores para alimentar a coleção e divulgar essa publicação em outros espaços.

Em 1929, Lourenço Filho formou-se bacharel em Ciências Jurídicas e Sociais - curso iniciado antes de sua partida para o Ceará - pela Faculdade de Direito de São Paulo. Em 1930, foi nomeado diretor-geral da Instrução Pública do Estado de São Paulo. Nessa função, reorganizou a diretoria, mudando-lhe a denominação para Diretoria-Geral do Ensino e fazendo-a compreender, entre outros, a Biblioteca Pedagógica Central e o Museu da Criança.

Em 1932, foi um dos signatários do Manisfesto dos Pioneiros da Educação Nova - marco do movimento escolanovista no Brasil -, no qual, segundo Azevedo (1963), buscou-se dar sentido à política brasileira de educação. Nesse mesmo ano, com Anísio Teixeira e Fernando de Azevedo, na cidade do Rio de Janeiro, então Distrito Federal, organizou o Instituto de Educação do Distrito Federal, onde permaneceu, como diretor, até 1937, e como professor de Psicologia Educacional, até 1938, tendo sido transferido, em 1939, para a Universidade do Brasil, também no Distrito Federal. Em 1933, fundou e dirigiu os Arquivos do Instituto de Educação.

A partir de 1935, recebeu os primeiros convites para ministrar cursos em universidades e institutos culturais estrangeiros, mostra de que o prestígio e respeito já alcançados por Lourenço Filho no Brasil extrapolavam nossas fronteiras e conquistavam novos espaços. Nos dois anos seguintes, foi presidente da Comissão Nacional

12 A Biblioteca de Educação foi organizada e colocada em prática por Lourenço Filho a partir de 1927, sendo a primeira coleção pedagógica criada no Brasil. A esse respeito, ver, especialmente, Warde (2003) e Carvalho e Toledo (2004). 
de Literatura Infantil, órgão normatizador ligado ao Ministério da Educação e Saúde, com o objetivo de organizar, delimitar e selecionar a literatura infantil produzida à época em nosso país. Durante esse período, juntamente com Murilo Mendes, Maria Eugenia Celso, Elvira Nizinska, Manuel Bandeira e Jorge de Lima, ${ }^{13}$ organizou, delimitou e selecionou a produção de literatura infantil da época, produzindo a partir daí o que pode ser considerado o início de uma teoria da literatura infantil brasileira. ${ }^{14}$

De agosto de 1938 a janeiro de 1943, Lourenço Filho organizou e dirigiu, no Rio de Janeiro, o Instituto Nacional de Estudos Pedagógicos (INEP), órgão de documentação e pesquisas no setor da educação, fundando, em 1944, a Revista Brasileira de Estudos Pedagógicos (RBEP), publicação vinculada a esse instituto. ${ }^{15}$ Entre as muitas atuações de Lourenço Filho junto a essa revista, como a de diretor e redator de todos os editoriais de seus números de 1944 a 1952, interessa para os objetivos deste texto sua orientação, como diretor da RBEP, na investigação acerca de jornais e revistas em quadrinhos para crianças e jovens, publicada de novembro de 1944 a fevereiro de 1945, nos números 5, 6, 7 e 8 da revista, sob o título "Uma investigação sobre jornais e revistas infantis e juvenis", a qual compreende duas partes: análise da apresentação material, das ilustrações e do conteúdo de revistas e jornais para crianças e jovens; e descrição e análise do resultado da aplicação de questionário aos leitores de 8 a 16 anos, familiares e professores, para verificação da influência dessas leituras.

Em 1941, presidiu a Comissão Nacional de Ensino Primário e organizou e secretariou a I Conferência Nacional de Educação. No ano de 1946, assumiu o cargo de professor de Psicologia Educa-

13 Alguns documentos consultados atestam a participação também do escritor José Lins do Rego e da poetisa e educadora Cecília Meireles, nessa Comissão.

14 Estudo a respeito da atuação de Lourenço Filho como presidente da Comissão Nacional de Literatura Infantil pode ser encontrado em Bertoletti (2008).

15 Sobre a atuação de Lourenço Filho frente à Revista Brasileira de Estudos Pedagógicos, ver, especialmente, Gandini (1995). 
cional na Faculdade Nacional de Filosofia do Rio de Janeiro, onde permaneceu até se aposentar, em 1956.

Antes da aposentadoria, em 1947, como diretor-geral do Departamento Nacional de Educação, Lourenço Filho planejou e dirigiu a Campanha Nacional de Alfabetização de Adultos, "[...] primeiro movimento de educação popular de iniciativa do governo federal" (Associação Brasileira de Educação, 1959, p.230).

Em 1948, presidiu a Comissão para elaboração do anteprojeto da Lei de Diretrizes e Bases da educação brasileira e, em 1949, organizou e dirigiu o Seminário Interamericano de Alfabetização de Adultos, no qual recebeu o título de "Maestro de las Américas", e fundou a Associação Brasileira de Psicologia, tendo sido eleito seu presidente.

Em 1952, foi eleito presidente do Instituto Brasileiro de Educação, Ciência e Cultura; em 1954, recebeu uma placa laudatória da "Câmara Brasileira do Livro"; e em 1955, presidiu o I Seminário Latino-Americano de Psicologia Aplicada. Em 1956 e 1957, foi membro da Comissão de Concurso de Literatura Infantil. Em 1956, quando se aposentou, a Universidade do Brasil concedeu-lhe o título de "professor emérito", e o Governo da República inaugurou com seu nome a Ordem Nacional de Mérito Educacional, no grau de Egregius. Ainda por ocasião de sua aposentadoria, Lourenço Filho recebeu o título de professor honorário da Universidade Mayor de São Marcos de Lima, no Peru, e foi eleito membro da American Statistical Association of the United States.

Em todo esse período, sobretudo a partir da década de 1930, Lourenço Filho intensificou o número de suas publicações. Com a aposentadoria, dedicou-se mais intensamente a sua produção escrita, bem como procedeu à revisão e ampliação de seus livros publicados que já alcançavam inúmeras edições. Segundo Ruy Lourenço Filho (2001), muitos escritos originais dessa época encontram-se dispersos em prefácios ou ensaios introdutórios de várias obras, em número superior a uma centena.

Pelo conjunto de sua obra, em 1963, Lourenço Filho recebeu o prêmio "Ciência da Educação", da Fundação Moinho Santista, e 
em 1978, com a criação da Academia Brasileira de Literatura Infantil e Juvenil, ${ }^{16}$ Lourenço Filho foi eleito patrono da cadeira no 11 .

O último trabalho de Lourenço Filho, antes de sua morte, em três de agosto de 1970, aos 73 anos de idade, "[...] foi o de presidir a comissão que organizou o programa de pós-graduação em psicologia no ISOP, da Fundação Getúlio Vargas" (Penna, 1989, p.30). Seu último escrito foi o prefácio à tradução brasileira de Agostinho Minicucci do livro Problemas e métodos no ensino da leitura, escrito pela educadora argentina Berta Braslavsky e publicado, em 1971, pela Editora Melhoramentos, na coleção Biblioteca de Educação.

Em 1987, a Companhia Melhoramentos de São Paulo distribuiu o "Prêmio Lourenço Filho" a autores brasileiros e estrangeiros mais notáveis, pela consagração pública que tiveram seus livros publicados por aquela editora. A homenagem da editora a Lourenço Filho, dando seu nome ao prêmio, é assim justificada pelo doutor Alfred Karl Ploeger, presidente do Conselho de Administração da Companhia Melhoramentos de São Paulo:

A láurea é igualmente homenagem que prestamos ao notável intelectual Lourenço Filho. Além de escritor fecundo, foi um dos principais educadores e dos mais importantes renovadores do ensino brasileiro. (Ploeger, 1987, p.8)

Na ocasião, Lourenço Filho foi laureado postumamente com o "Troféu Platina", ao lado de outros escritores, como Edy Lima, Francisco Marins, Renato Sêneca Fleury, ${ }^{17}$ Tales de Andrade e Ziraldo Alves Pinto.

16 A Academia Brasileira de Literatura Infantil e Juvenil foi fundada, em São Paulo, em 21 de março de 1978, e resultou "[...] de uma consulta a mais de quatrocentos homens de letras de todo o Brasil, após reunião, em São Paulo, de um grupo de escritores preocupados 'principalmente com a criação dirigida à criança e ao jovem, constantemente solicitados por outros interesses'”, (Tahan, s.d.). De acordo com informações que localizei, em 2 de fevereiro de 1979, foram diplomados quarenta escritores eleitos para integrar a Academia Brasileira de Literatura Infantil e Juvenil.

17 Informações sobre Renato Sêneca Fleury encontram-se em texto de Cyntia Grizzo Messenberg que integra este livro. Estudos minuciosos sobre esse autor e sua obra foram desenvolvidos por Magnani (1997), Mortatti (2000) e Messsenberg (2011) [N. O.]. 


\section{O escritor Lourenço Filho}

Segundo Ruy Lourenço Filho (1997), o escritor Lourenço Filho parece ter tido papel fundamental, dada a vastidão e importância de seus escritos, na constituição do educador Lourenço Filho. Admitido o escritor Lourenço Filho dessa forma, é possível afirmar que, após "puxar a fieira" d'O Pião (Marins, 1997), Lourenço Filho iniciou a obra de sua vida.

Mais do que uma brincadeira de criança, quando observada sua duração no tempo, que, segundo Ruy Lourenço Filho (1997), alcançou mais de um ano, $O$ Pião, cujo primeiro número data de 16 de julho de 1905, buscava "[...] dar algumas ferroadas em quem merecer, e também nos alumnos das escolas de P. Ferreira" (idem, 1905, n.p), além de noticiar festas, aniversários, dar conselhos etc., mas não buscava tratar " $[\ldots]$ de cousas importantes, pois é dirigido por um menino que não está abilitado a isso" (ibidem, n.p).

O menino Lourenço Filho cresceu e, muito jovem ainda, passou a aspirar à literatura, influenciado, entre outras, pela leitura de Os Sertões, de Euclides da Cunha, cujos temas chegou a discutir com seus mestres na escola normal primária, em Pirassununga (Marins, 1987).

Assim, apesar da "cultura deficiente" modestamente autodenominada por Lourenço Filho na já referida entrevista à revista Formação, quando formado professor primário, ele começou, em 1915 e 1916, a publicar não apenas literatura, mas também crítica literária na revista Vida Moderna. Lourenço Filho teve publicados, nessa época, os seguintes contos e crônicas: "Suicida (das cartas de Noel Felix)" (1915), "Conto de serão" (1915), "Clarita (notas para um conto)" (1916), "De Pierrete" (1916), "O Bock (notas para um conto)" (1916), "Carta de amor" (1916), "Presente de anos" (1916), "Chronica vadia" (1916), e os seguintes ensaios de crítica literária: "Impressionismo nas Letras" (1915), "Chronica (sobre estilo de Fialho de Almeida)", "Chronica (sobre estilo de Euclides da Cunha)" (1916).

À literatura e crítica literária produzida por Lourenço Filho vieram juntar-se reflexões a respeito dos problemas da leitura e dos 
livros, que resultaram na publicação dos seguintes textos: "O que a criança lê" (1920), "Um inquérito sobre o que os moços leem” (1927), "O problema do livro nacional" (1938) e "O cinema e a literatura na educação da criança” (1939).

O primeiro livro do escritor, Joaseiro do Pe. Cícero, de 1926, misturava literatura e ciência, pois ao cientificismo dos dados precisos e comprovados por citações e à análise psicológica e sociológica do fenômeno do Padre Cícero juntou-se uma linguagem pormenorizada, descritiva e narrativa, entremeada de sensibilidade e poesia, além de refinada ironia, especialmente nos primeiros quatro capítulos. Nele, segundo Monarcha (2001), Lourenço Filho exercitou sua "vocação de escritor", em estilo euclidiano, do ponto de vista de uma "mente ilustrada".

Teve publicados, ainda, ao longo de sua carreira mais alguns textos de literatura ou com ela relacionados, como "O carvalho arrancado" (1919) e "A padaria espiritual" (1923); e textos de crítica literária, como "O menino e o palacete" (1954), "O simbolismo de 'O menino e o palacete" “ (1955), "Um romance paulista: 'Clarão da Serra" (1962), "Linguagem num romance paulista” (1964); e o texto de recepção ao acadêmico Francisco Marins na Academia Paulista de Letras "Oração do acadêmico Lourenço Filho" (1966), que, embora não seja um texto especificadamente de crítica literária, nele esta está bastante presente.

A crítica literária produzida por Lourenço Filho consistiu, basicamente, em análises de aspectos formais, estilísticos e estruturais dos textos, como "lições" e propaganda de produção literária, feitas pelo crítico "desavisado" - como se autodenominava. Essa crítica aponta para a autoridade de que se foi revestindo o nome de Lourenço Filho em matéria de literatura, timidamente em 1915 e 1916, e mais relevante e importante ao longo dos anos seguintes, vindo a ser consultor editorial, conforme já informado, da Companhia Melhoramentos, uma das seis maiores editoras de livros para crianças do país, à época.

Como já informei, a partir de 1926, a produção de literatura infantil passou a fazer parte das atividades do escritor Lourenço Filho, quando passou a revisar os textos da coleção Biblioteca In- 
fantil, que constava de histórias tradicionais, orientadas e revisadas. A partir de 1937, essa atividade intensificou-se, por meio da revisão de textos e orientação a autores e/ou adaptadores, até 1957, quando a coleção totalizou cem títulos (Arroyo, 1968).

[...] Esta revisão objetivou a simplificação do vocabulário, de modo a atingir maior público infantil em função da idade, e a expungir as estórias de certas passagens menos satisfatórias, por inspirarem sentimentos de medo, ou terror. Esse trabalho de Lourenço Filho se constata pelo confronto entre as edições originais até 1926, e as reedições a partir dessa data. (ibidem, p.187)

De acordo com Marins (1997), Lourenço Filho se propôs a escrever para crianças convencido da possibilidade de adaptação de "estórias tradicionais" aos novos "ditames didáticos", eliminando delas o "humor negro". "Lourenço desejava que a leitura pudesse se tornar uma ponte entre o mundo da criança e o do adulto e não uma pinguela para derrubá-la no abismo” (ibidem, p.83).

Lourenço Filho [...] levaria ao mais alto grau o conceito já explícito no Emílio, de Rousseau: a criança não só devia ser estudada mas antes, compreendida, e daí propor, como integrantes inseparáveis das narrativas - mesmo que de formas veladas - preceitos da Psicologia Infantil e da Pedagogia e afastando, como já dito, conceitos de terror e violência, e ainda, o sentido piegas ou moralista, muito a gosto de velhos catecismos aplicados à educação.

Assim seu conceito de tal literatura era a de que devia exercer uma função humanizadora, porém com os ingredientes da fantasia, da evasão e do sonho e ser uma forma de fazer conhecer o próprio ser e o mundo e, assim, tornar-se uma ponte entre o mundo risonho da criança e o carrancudo do adulto. (ibidem, p.85-86)

Para Menin (1999), a revisão de O patinho feio feita por Lourenço Filho na coleção Biblioteca Infantil não se caracterizou apenas pela revisão do texto de Barreto - recriador da primeira edição, em 1915, 
desse conto, na coleção —-, mas tratou-se de uma "recriação", devido à ampla modificação que processou em relação ao texto original de Hans Christian Andersen, segundo seu projeto e sua autonomia de trabalho frente à coleção. No entanto, de acordo com a autora, como Lourenço Filho e Barreto "falavam" a partir de um mesmo "lugar" - o escolar -, demonstravam em sua atuação frente à coleção preocupações similares, como as de preservar a arte e incentivar o gosto pela leitura nas crianças em situação escolar, por isso, em $O$ patinho feio de Lourenço Filho sobressaiu-se o tom didático com intenção de educar, evidenciando os papéis de quem ensina e o de quem aprende, em um enfoque formativo, moralizante e de crítica social. Isso, no entanto, não prejudicou a contribuição significativa de Lourenço Filho “[...] para a constituição, manutenção e maior idade do gênero literário infantil” (ibidem, , p.169, destaques no original).

Soares (2002, p.312), por sua vez, ao comentar as revisões de Lourenço Filho dos livros dessa coleção, afirma que, nesse projeto editorial, "[...] o leitor em formação tinha etapas bem definidas a cumprir, guiado pela mão do mediador [Lourenço Filho], que convidava, mas controlava".

O exercício também da função de consultor editorial para livros destinados a crianças na Companhia Melhoramentos, nessa época e ao longo de várias décadas, estreitou os laços do autor com a literatura infantil. Lourenço Filho examinava os textos originais e também as traduções e adaptações que aspiravam à publicação, submetendo-os a correções ortográficas e de "fundo" e "forma", mas sempre respeitando, segundo Marins (1997), os conceitos dos autores, e quando Lourenço Filho pressentia um novo bom autor, "[...] propunha-se a orientá-lo e até reescrevia trechos de seus trabalhos" (ibidem, p.86).

Nessa tarefa, de acordo com Marins (ibidem), Lourenço Filho chegou a emitir "mais de cinquenta mil pareceres". ${ }^{18}$

18 Como se pode perceber, há divergências a respeito do número de pareceres emitidos por Lourenço Filho ao longo das varias décadas em que foi consultor editorial da Companhia Melhoramentos de São Paulo: Donato (1990) registra "quase" 30 mil, e Marins (1997), "mais de" 50 mil. 
Naquela tarefa [Lourenço Filho] haveria de remodelar textos, propor novas lições, limar períodos, acrescentar dados pertinentes, isto sem ferir a genuinidade das obras, nem provocar a crítica dos autores. (idem, 1987, n.p.)

O conteúdo dos pareceres de Lourenço Filho constitui-se de "lições de produção literária para crianças", pois nesses pareceres ele não apenas julgava os trabalhos em apreciação, como também discorria sobre aspectos teóricos da literatura infantil.

Essas experiências, assim como a presidência da Comissão Nacional de Literatura Infantil, oportunizaram a Lourenço Filho receber o convite, do presidente da Academia Brasileira de Letras, em 1943, para falar aos membros da Academia a respeito da literatura infantil e seus problemas. Nessa palestra, publicada na Revista Brasileira (Rio de Janeiro) sob o título "Como aperfeiçoar a literatura infantil”, no mesmo ano, Lourenço Filho demonstrou grande conhecimento do assunto, sintetizando conceitos básicos sobre o gênero, o que tornou esse artigo pioneiro na produção mais sistematizada sobre o gênero.

Nele, Lourenço Filho problematizou a questão da literatura infantil, a fim de contribuir para os estudos e debates em torno do gênero. Para tanto, o autor buscou, a partir de dados históricos, conceituar e delimitar a literatura infantil e estabelecer suas funções e modalidades, além de fazer um balanço da situação então atual e sugerir medidas para aperfeiçoá-la.

Depois disso, Lourenço Filho produziu uma série de textos sobre leitura e literatura infantil e juvenil, como "O ensino e a biblioteca" (1945), "O valor das bibliotecas infantis" (1948), "A criança da literatura brasileira” (1948), "Literatura infantil e juvenil” (1957), “Anteprojeto" de programa de ensino de literatura infantil (1957), ${ }^{19}$ "Inquérito sobre livros para crianças" ( 1959), "Lúcia Benedetti e o teatro infantil" (s.d.), "Como tornar cada criança e cada adoles-

19 Análise da configuração textual do "Anteprojeto" de Lourenço Filho encontra-se em Oliveira $(2013 ; 2014)$. 
cente um bom consumidor de leitura (1966), além de introdução, apresentação e prefácio a livros de e sobre literatura infantil, como, entre tantos outros, "Prefácio" (1959) - ao livro Vamos recitar, poesia e teatro infantil, de Maria de Lourdes Nunes de Andrade; "Introdução" (1962) - ao livro Brasil: paisagens e costumes; "Prefácio" (1962) - ao livro Nuvens choronas, de Luis M. Nery; "Apresentação" (s.d.) - ao livro A história da árvore de Natal, de Hertha Pauli; "Um livro básico sobre literatura infantil" (1968) - prefácio ao livro Literatura infantil brasileira - ensaio de preliminares para sua história e suas fontes, de Leonardo Arroyo.

Em suas preocupações com a literatura infantil, as questões da educação continuavam a incomodar Lourenço Filho, uma vez que sua produção de e sobre o gênero estava contida em um projeto maior de educação e cultura, conforme já afirmado. Sintonizado com os anseios e as necessidades de sua época sobre a educação e seus problemas e, nesse âmbito, sobre a leitura e, consequentemente, a literatura e a literatura infantil, Lourenço Filho reconhecia que era preciso educar o povo para o progresso social e que o ensino da leitura era um dos elementos de educação popular (Lourenço Filho, 1928). Em vista disso, teve publicada, a partir de 1928, extensa produção didática, que abrange desde cartilhas de alfabetização até livros para leitura escolar. Importante é, no entanto, observar que ele não se descuidou de sua produção de literatura infantil, uma vez que esta constituía o meio para a leitura.

No âmbito dessa produção didática, teve publicadas a já citada Cartilha do povo - para ensinar a ler rapidamente (1928), a cartilha Upa, cavalinho! (1957) e os livros de leitura da Série de Leitura Graduada Pedrinho, com os títulos Pedrinho (1953), Pedrinho e seus amigos (1954), Aventuras de Pedrinho (1955), Leituras de Pedrinho e Maria Clara (1956) e Pedrinho e o mundo (1957).

Vale lembrar que, antes da série de leitura mencionada, teve publicada a Série Histórias do Tio Damião, com doze títulos: Totó (1942), Baianinha (1942), Papagaio Real (1943), Tão pequenino... (1943), Saci-Pererê (1944), O indiozinho (1944), A irmã do indiozinho (1946), A gauchita (1946), A formiguinha (1946), No circo (1946), Maria do Céu (1951), E eu, também... (1951). 
A Série Histórias do Tio Damião configura-se como produção original de Lourenço Filho de literatura infantil. Produzida na maturidade intelectual do autor, essa série circulou por dezesseis anos no mercado editorial brasileiro, com um total aproximado de 600 mil exemplares. Suas histórias, indicadas para leitores de 6 a 8 anos, tematizaram o cotidiano de Dedé, uma menina pequena, curiosa e esperta que vive algumas travessuras e aprende, por meio de histórias contadas pelo Tio Damião ou por outros contadores de histórias e por meio de diálogos com outras crianças, tipos, usos e costumes regionais, bem como aspectos do folclore brasileiro.

Pela produção dessa série, Arroyo (1968) situa Lourenço Filho entre os autores que se destacavam por uma obra literária para crianças perfeitamente "definida e válida", a lado de outros, como Guilherme de Almeida, Lúcia Machado de Almeida, Menotti del Pichia, Hernâni Donato, Érico Veríssimo, Maria José Dupré, Malba Tahan, José Lins do Rego e Luís Jardim. "Em Lourenço Filho o tema histórico se junta ao da ficção e ao do folclore para resultar na série Histórias do Tio Damião para crianças até 8 anos de idade" (ibidem, p.226).

Já Lajolo e Zilberman (1984) avaliam que tanto essa série quanto a Série de Leitura Graduada Pedrinho foram produzidas para completar a atuação de Lourenço Filho como pedagogo. Para as autoras, a Série Histórias do Tio Damião "[...] transmite informações sobre usos e costumes regionais, reforçando as noções de comunidade brasileira e integração nacional, valores em evidência na época, que o livro de orientação didática acentua" (ibidem, p.80). Acrescentam que, apesar de Histórias do Tio Damião não se destinar diretamente ao ensino, nos textos dessa série predomina a finalidade educativa, "[...] somada ao dirigismo ideológico, os quais variam segundo as intenções dos setores que utilizam a literatura para difundir conceitos e posições que lhes interessam em particular" (ibidem, p.80).

É importante ressaltar, no entanto, que o projeto editorial da Série de Leitura Graduada Pedrinho foi levado adiante a partir de 1953, ou seja, dois anos depois de encerrado o projeto editorial 
da Série Histórias do Tio Damião. Assim, o intervalo de tempo que separa essa produção declaradamente didática da produção de literatura infantil de Lourenço Filho é indicativo de que, de acordo com o ponto de vista de seu autor, Histórias do Tio Damião foi produzida como literatura infantil, e a Série de Leitura Graduada Pedrinho foi produzida como leitura escolar, de caráter didático.

Já o livro São Paulo, publicado em 1954 pela Companhia Melhoramentos de São Paulo, segundo Afrânio Coutinho (1978), integra a produção de literatura juvenil de Lourenço Filho. Nesse livro conserva-se a figura do Tio Damião, que narra aos meninos Benedito, Zezinho e Joaquim aspectos geográficos, históricos e culturais do estado de São Paulo. Segundo Afrânio Coutinho (ibidem), embora esse livro tenha sido escrito para jovens, pode também ser lido por adultos, que, como os jovens, aprenderão e se encantar, dada a variedade de temas, os comentários agudos, as informações seguras e a linguagem elegante e apropriada.

São Paulo faz parte da Série Viagem através do Brasil, organizada e revisada por Lourenço Filho, toda ela publicada pela Companhia Melhoramentos de São Paulo entre as décadas de 1940 e 1950. Essa série, segundo consta na quarta capa desse livro, é um "Autêntico desfile das grandezas de nossa terra através de seus costumes, encantos naturais, formação histórica, acidentes geográficos, etc." (São Paulo, 1954, n.p.), composta de "Volumes caprichosamente ilustrados, constituindo a coleção um precioso documentário" (ibidem,, n.p.). Consta de dez volumes, na seguinte ordem: Vol. 1 - Amazonas e Pará; Vol. 2 - Maranhão, Piauí, Ceará, Rio Grande do Norte, Paraíba, Pernambuco, Alagoas e Sergipe; Vol. 3 - Bahia, Espírito Santo e Rio de Janeiro; Vol. 4 - Minas Gerais; Vol. 5 - Rio Grande do Sul; Vol. 6 - Santa Catarina; Vol. 7 - Paraná; Vol. 8 Distrito Federal; Vol. 9 - São Paulo; Vol. 10 - Goiás e Mato Grosso. Com exceção dos volumes 8 e 9, de autoria de João Guimarães e de Lourenço Filho, respectivamente, todos os demais volumes foram escritos por Ariosto Espinheira.

A Série Viagem através do Brasil apresenta semelhanças com Através do Brasil, de Olavo Bilac e Manoel Bonfim, publicado em 
1910, e é "[...] leitura apaixonada e obrigatória de muitas gerações de brasileiros" (Lajolo; Zilberman, 1991, p.34). Essas semelhanças dizem respeito à tematização do nacionalismo em ambos, no sentido de conhecer as terras brasileiras, como meio de exaltá-las e valorizar sua natureza, seu povo e suas regiões. Ou seja, trata-se de uma visão ufanista do Brasil, visando a garantir a unidade nacional em sua diversidade regional. Ao mesmo tempo informativos e de ficção, São Paulo e Através do Brasil buscam envolver o leitor e garantir sua adesão.

\section{Considerações finais}

Analisando a faceta do escritor Lourenço Filho, Ruy e Márcio Lourenço Filho (1959) afirmam que o que caracteriza a obra de seu pai é o esforço do "publicista pedagógico" com o propósito de contribuir para uma mentalidade esclarecida em matéria de educação. Para esses autores, essa obra pode ser "distribuída" em quatro categorias: "educação em geral”, "psicologia”, "pensamento social” e "escritos para crianças".

Em todos seus escritos, Lourenço Filho tem mantido coerência de ideias e atitudes, e uma inabalável fé no valor da educação e da cultura. Mas, ao mesmo tempo, neles traduz um empenho de renovação e atualização incessante. [...]

O respeito pelo leitor, na exatidão que deseja imprimir a seus escritos, tem sido outra nota constante, o que explica por certo a autoridade de que se revestem seus trabalhos, no país e no estrangeiro. (Lourenço Filho; Lourenço Filho, 1959, p.203)

Para Peregrino Junior (1959), o escritor Lourenço Filho é também filósofo, sociólogo, psicólogo e pedagogo, sendo, por isso, um "escritor autêntico".

A sua arte de escrever é sutil, isenta e preclara. Sabe escrever com fluência, elegância e correção, escrevendo muito bem, exata- 
mente porque dá a ilusão de estar escrevendo sem a preocupação de escrever bem. Não se veem, na sua prosa, os andaimes da construção. E esse, no avisado conselho de Machado de Assis, é o melhor estilo: desataviado, claro, direto. Aparentei-o sempre, pela erudição extensa, pela expressão fácil e pelo dom admirável da clareza, ao de Medeiros e Albuquerque. (ibidem, p.182-3, destaques no original)

Já segundo Marins (1987, n.p.), Lourenço Filho se comunicava "[...] de maneira clara e objetiva, com vocabulário precioso e adequado, sinonímia rica, quando falasse ou escrevesse", adotando o método do "contador de histórias".

Ainda de acordo com Marins (1997), Lourenço Filho se propôs a escrever para crianças convencido da possibilidade de adaptação de "estórias tradicionais" aos novos "ditames didáticos", eliminando delas o "humor negro", como já afirmado textualmente.

Dialogando com esses autores, para mim, Lourenço Filho, escritor de e sobre literatura infantil e juvenil, em sua numerosa e variada produção de e sobre esse gênero e a ele correlata - como textos de literatura (para adultos) e de crítica literária, livros de literatura infantil e juvenil, livros didáticos para ensino da leitura, textos sobre leitura, livros e literatura infantil e juvenil, revisão e orientação de textos de literatura infantil e juvenil e introdução, apresentação e prefácios a textos de e sobre o gênero -, tem aí mais um aspecto desse intelectual que, dentro de sua obra voltada para um projeto de educação, relacionou também essa produção às urgências educacionais e culturais de seu tempo.

Como se pôde perceber, a produção de literatura (para adultos) de Lourenço Filho ocupou, predominantemente, o tempo da juventude do escritor - de 1915 a 1926 -, o que parece justificar a constatação do escritor Josué Montello sobre a renúncia de Lourenço Filho à criação literária - "[...] a que ele poderia ter dedicado" (Josué Montello apud Lourenço Filho, 1997, p.44) -, em benefício de uma obra de educação. A produção de literatura infantil e juvenil, sejam as revisões e orientações, sejam as produções originais, 
como a Série Histórias do Tio Damião ou São Paulo, foi proposta para "funcionar" como literatura infantil e juvenil, e não como leitura escolar, distinguindo-se dos livros didáticos produzidos pelo mesmo autor para o ensino da leitura, como já afirmado, mas não sem "formar" valores lógicos, sociais e morais. O mesmo se pode afirmar em relação à produção sobre esse gênero, que partia do pressuposto de que a criança tem necessidade inerente de formação, no que diz respeito a seu "mundo interior", e de que a leitura exerce uma "ação cultural”, sendo, por isso, a literatura infantil e juvenil instrumento de ação "educativa". Ação esta questão de "brasilianismo”, ou seja, para progresso social.

Assim, sintonizado com as urgências de sua época, Lourenço Filho, escritor de e sobre literatura infantil e juvenil, merece ter essa produção estudada, bem como tantos outros aspectos antes inexplorados, conforme se vem percebendo na história da educação brasileira. Restam, no entanto, muitos outros, às vezes esquecidos, às vezes considerados menores, mas que fizeram parte da constituição da obra de uma vida, tão intensa e significativa.

\section{Referências bibliográficas}

ARROYO, L. Literatura infantil brasileira - ensaio de preliminares para sua história e suas fontes. São Paulo: Melhoramentos, 1968.

ASSOCIAÇÃO BRASILEIRA DE EDUCAÇÃO (ABE). Um educador brasileiro: Lourenço Filho. São Paulo: Edições Melhoramentos, 1959. Livro Jubilar.

AZEVEDO, F. de. A cultura brasileira. 4.ed. Brasília: Editora Universidade de Brasília, 1963.

BERTOLLETTI, E. N. M. Cartilha do povo $e$ Upa,cavalinho!: o projeto de alfabetização de Lourenço Filho. Marília, 1997. 129f. Dissertação (Mestrado em Educação) - Faculdade de Filosofia e Ciências, Universidade Estadual Paulista.

A produção de Lourenço Filho sobre e de literatura infantil e juvenil (1942-1968): fundação de uma tradição. Marília, 2006a. 275f. Tese (Doutorado em Educação) - Faculdade de Filosofia e Ciências, Universidade Estadual Paulista. 
Lourenço Filho e a alfabetização - um estudo de Cartilha do povo e da cartilha Upa, cavalinho!. São Paulo: Editora Unesp, 2006b.

A produção de Lourenço Filho de e sobre literatura infantil: um instrumento de pesquisa. In: A produção de Lourenço Filho sobre e de literatura infantil e juvenil (1942-1968): fundação de uma tradição. Marília, 2006c. 275f. Tese (Doutorado em Educação) - Faculdade de Filosofia e Ciências, Universidade Estadual Paulista.

Lourenço Filho e literatura infantil e juvenil. São Paulo: Editora Unesp, 2012.

CARVAlHO, M. M. C. de; TOLEDO, M. R. de A. A coleção como estratégia editorial de difusão de modelos pedagógicos: o caso da Biblioteca de Educação organizada por Lourenço Filho. In: II Congresso Brasileiro de História da Educação, 2004, Curitiba.

COUTINHO, A. Notas de teoria literária. 2.ed. Rio de Janeiro: Civilização Brasileira, 1978.

DONATO, H. Cem anos de Melhoramentos: 1890-1990. São Paulo: Melhoramentos, 1990.

LAJOLO, M.; ZILBERMAN, R. Literatura infantil brasileira: história \& histórias. São Paulo: Ática, 1984.

. Literatura infantil brasileira: história \& histórias. 5.ed. São Paulo: Ática, 1991.

LOURENÇO FILHO, M. B. O Pião. Porto Ferreira, 1905.

Cartilha do povo - para ensinar a ler rapidamente. São Paulo: Melhoramentos, 1928. 47p., il.

. Carta de Lourenço Filho a Anísio Teixeira. São Paulo, 1 nov 1929. 2 f. Hoje fala Lourenço Filho. Formação, Rio de Janeiro, ano III, n.19, p.3-18, fev. 1940.

A resposta de Lourenço Filho, 1926. In: AZEVEDO, F. de. A educação na encruzilhada. 2.ed. São Paulo: Melhoramentos, 1957. (Obras completas, v.VI)

LOURENÇO FILHO, R.; LOURENÇO FILHO, M.. Notícia bibliográfica de Lourenço Filho. In.: ASSOCIAÇÃO BRASILEIRA DE EDUCAÇÃO (ABE). Um educador brasileiro: Lourenço Filho. São Paulo: Edições Melhoramentos, 1959, p.190-203. Livro Jubilar.

. Lourenço Filho, escritor. In: MONARCHA, C. (org). Centenário de Lourenço Filho: 1897-1970. Londrina: Universidade Estadual de Londrina; Marília: Universidade Estadual Paulista; Rio de Janeiro: Associação Brasileira de Educação, 1997, p.17-45 
MAGNANI, M do R. M.. Os sentidos da alfabetização: a "questão dos métodos" e a constituição de um objeto de estudo (São Paulo/18761994). Presidente Prudente, 1997a. 389f. Tese (Livre-Docência em Metodologia do Ensino de 1ํo Grau: Alfabetização) - Faculdade de Ciências e Tecnologia, Universidade Estadual Paulista.

. Testes $A B C$ e a fundação de uma tradição: alfaetização sob medida. In: MARINS, F. Lourenço Filho e a arte de ensinar. O Estado, São Paulo, 3 out. 1987.

. Literatura infantil e Lourenço Filho. In: MONARCHA, C. (Org). Centenário de Lourenço Filho: 1897-1970. Londrina: Universidade Estadual de Londrina; Marília: Universidade Estadual Paulista; Rio de Janeiro: Associação Brasileira de Educação, 1997, p.77-89

MENIN, A. M. da C. S. O patinho feio de H. C. Andersen: o "abrasileiramento" de um conto para crianças. Assis, 1999. 280f. Tese (Doutorado em Letras) - Faculdade de Ciências e Letras, Universidade Estadual Paulista.

MONARCHA, C. (org.). Lourenço Filho: outros aspectos, mesma obra. Campinas: Mercado de Letras; Curso de Pós-Graduação em Educação: Campus de Marília, 1997b, p.59-90.

Leitura e cultura: considerações sobre a produção didática de Lourenço Filho. In: MONARCHA, C.; LOURENÇO FILHO, R. (orgs.). Por Lourenço Filho: uma biobibliografía. Brasília: Inep/MEC, 2001, p.145-157. (Coleção Lourenço Filho)

. O sertão cearense segundo Lourenço Filho. Marília, 2001. 163f. Tese (Livre-Docência em História da Educação Brasileira) - Faculdade de Filosofia e Ciências. Universidade Estadual Paulista.

; LOURENÇO FILHO, R. (orgs.). Por Lourenço Filho: uma biobibliografía. Brasília: Inep/MEC, 2001. (Coleção Lourenço Filho). MORTATTI, M. do R. L. Os sentidos da alfabetização (São Paulo 1876/1994). São Paulo: Editora Unesp; Brasília: MEC/Inep/Comped, 2000.

OLIVEIRA, F. R. de. As prescrições de Lourenço Filho, na década de 1950, para o ensino da literatura infantil nos cursos normais paulistas. Anais do VII Congresso Brasileiro de História da Educação. 2013. Disponível em: <http://sbhe.org.br/novo/congressos/cbhe7/pdf/08-\%20 IMPRESSOS-\%20INTELECTUAIS\%20E\%20HISTORIA $\% 20$ DA\%20EDUCACAO/AS\%20PRESCRICOES\%20DE\%20LOURENCO\%20FILHO-\%20NA\%20DECADA\%20DE\%201950.pdf>. Acesso em: set. 2013. 
PENNA, A. G. Acerca dos psicólogos-educadoresna cidade do Rio de Janeiro: Manoel Bonfim, Maurício de Campos Medeiros, Plínio Olinto e Lourenço Filho. Forum Educacional, n.13, v.3, p.7-34, jun.-ago. 1989.

PEREGRINO JÚNIOR, J. Lourenço Filho, escritor. In: ASSOCIAÇÃO BRASILEIRA DE EDUCAÇÃO (ABE). Um educador brasileiro: Lourenço Filho. São Paulo: Edições Melhoramentos, 1959, p.182-3. Livro Jubilar.

PLOEGER, A. K. Discurso. São Paulo: Melhoramentos, 1987.

SÃO PAULO. Quarta capa. In: LOURENÇO FILHO, M. B. São Paulo. São Paulo: Melhoramentos, 1954. (Série Viagem através do Brasil, 9)

SOARES, G. P. A semear horizontes: leituras literárias na formação da infância, Argentina e Brasil (1915-1954). São Paulo, 2002. 339f. Tese (Doutorado em História) - Faculdade de Filosofia, Letras e Ciências Humanas, Universidade de São Paulo.

TAHAN, A. M. Os 40 imortais da literatura infanto-juvenil. Jornal do Brasil. [s. 1.], [s. p.], [s. d.].

WARDE, M. J. O itinerário de formação de Lourenço Filho por descomparação. Revista Brasileira de História da Educação, Campinas, v.5, p.125-167, 2003. 


\section{1 \\ O EDUCADOR PAULISTA ANTÔNIO D'ÁVILA (1903-1989): SUA ATUAÇÃO E SUA PRODUÇÃO ESCRITA ${ }^{1}$}

Thabatha Aline Trevisan

\section{Introdução}

Neste texto, apresento a trajetória profissional e a produção escrita do educador paulista Antônio D'Ávila (1903-1989), com objetivo de contribuir para a compreensão de um importante aspecto da história da formação de professores primários (inclusive alfabetizadores) no Brasil, que se encontra diretamente relacionada com as discussões características do terceiro momento da história da alfabetização (Magnani, 1997; Mortatti, 2000).

Como apontam Magnani (1997) e Mortatti (2000), nesse momento sistematiza-se a produção, por brasileiros, de material didático para os cursos de formação de professores, então em expansão. Embora tratando de metodologia do ensino primário em geral, esses manuais apresentam também capítulos sobre ensino de diferentes matérias, entre elas a leitura e a escrita. (ibidem, p.172).

1 Este texto é resultante de pesquisas de iniciação científica e de mestrado, desenvolvidas, respectivamente, com Bolsas Pibic/CNPq/Unesp e Fapesp, cujos resultados finais foram apresentados sob a forma de Trabalho de Conclusão de Curso (Trevisan, 2003) e de dissertação de mestrado (Trevisan, 2007) [N. O.]. 
Originando-se das bem-sucedidas experiências didáticas de seus autores (como ocorreu com as cartilhas), a produção desses manuais de ensino acompanha

[... o o anseio de nacionalização e o novo "clima cultural da década dos vinte", a novidade, a partir de 1930, é a sedimentação de uma produção mais sistemática e frequente de educadores brasileiros e, dentre esses, paulistas -, que, abordando questões pedagógicas e, em particular, o aprendizado da leitura e escrita, passam a circular, entre o professorado paulista ao longo do momento em foco, sob a forma de: livros de divulgação, contendo ensaios, relatórios de pesquisas experimentais ou propostas de ensino originais; e manuais de ensino para uso especialmente em escolas normais e institutos de educação. (ibidem, p.154)

Antônio D’Ávila (1903-1989), que participou ativamente desse movimento, iniciou suas atividades como professor na década de 1920, lecionando em escolas rurais pelo interior do estado de São Paulo. Posteriormente, na década de 1930, esse professor deu início a sua extensa produção escrita, com a tradução do manual Didática da Escola Nova. D’Ávila teve atuação marcante no magistério paulista, e não há, além desse, estudos específicos que evidenciem essa sua atuação tanto profissional e sua produção escrita. Portanto, esse texto, síntese de trabalhos acadêmicos que elaborei, expõe a importância desse educador no campo educacional paulista e brasileiro.

\section{Sobre o autor e sua atuação profissional ${ }^{2}$}

Antônio D'Ávila nasceu em Jaú (SP), aos 13 de julho de 1903, e foi o sexto filho de José d'Ávila e Olímpia Borges. Faleceu no dia

2 As informações apresentadas neste tópico foram extraídas de: Melo (1954);

O Prof. Antônio d'Ávila... (1963); A diretoria... (1963); Carvalho (1989);

D’Ávila [19--] (Curriculum vitae do educador); e D’Ávila (1983). 
26 de julho de 1989, aos 86 anos de idade, na cidade de São Paulo. Fez seus estudos primários nessa cidade, nos grupos escolares da Rua da Consolação, da Avenida Paulista e na Rua Santo Antônio, onde estudou seu 5o ano e diplomou-se como quartanista. Segundo D’Ávila, em entrevista gravada ao "Projeto Memória da Psicologia brasileira”, era professor nessa escola um complementarista chamado Salvador Rocco, que ele menciona como uma das figuras mais impressionantes que já conhecera e que exerceu influência decisiva sobre ele e seu magistério. Ingressou, em 1917, na Escola Normal Primária "Caetano de Campos", a famosa "Escola Normal da Praça da República”, diplomando-se em 1920. Nessa escola, foi discípulo de Lourenço Filho, ${ }^{3}$ por seis meses, tendo este professor substituído o professor Roldão Lopes de Barros na cadeira de Psicologia, Pedagogia e Prática de Ensino, em virtude da transferência de Barros para a escola do Brás. São palavras de D’Ávila (1980, p.3): “[Lourenço Filho] era um mocinho, entrou em nossa classe num dia de julho de 1920 com toda naturalidade, com toda simplicidade, como se fosse um velho amigo e começou a reformar o ensino de Psicologia [...]". D’Ávila foi leitor dos clássicos da Filosofia, da Literatura e da História, aprendeu lições de humanismo e adquiriu gosto pela leitura.

No início de sua carreira profissional, de 1920 a 1930, lecionou em escolas do interior do estado de São Paulo. Posteriormente, atuou como professor da Escola Rural de Irapé, em Xavantes, em 1921; foi professor das Escolas Reunidas do mesmo distrito em 1923; professor de Escola Normal Livre, lente de Didática, de Pedagogia, e diretor das Escolas Reunidas do Espírito Santo, em Itajobi, no período de 1923 a 1925; foi nomeado adjunto do Grupo Escolar de Santa Cruz do Rio Pardo, em 1925, substituindo o diretor em 1926; atuou como professor de Psicologia, Pedagogia, Didá-

3 Informações sobre Manoel Bergström Lourenço Filho encontram-se em texto de Estela Natalina Mantovani Bertoletti que integra este livro. Estudos minuciosos sobre esse autor e sua obra foram desenvolvidos por Magnani (1997), Mortatti (2000) e Bertoletti (1997; 2006) [N. O.]. 
tica, Matemática e Desenho da Escola Normal Livre de Santa Cruz do Rio Pardo; e foi nomeado, em 1925, adjunto do Grupo Escolar de Mirassol (SP).

A partir de 1931, passou a atuar na capital do estado, tendo sido aprovado em primeiro lugar no concurso para professor fiscal de Escola Normal Livre, exercendo suas atividades no Colégio Santa Inês, no qual trabalhou de 1931 a 1933. Foi professor de Português e História Geral também nesse colégio entre 1937 e 1940. D'Ávila foi, ainda, professor de Português e História da Civilização em cursos secundários de diversos colégios da capital. Foi assistente de Metodologia do Instituto de Educação da Universidade de São Paulo e, depois, foi aprovado em concurso para catedrático dessa cadeira, com direito à livre-docência, ${ }^{4}$ em 1935 . Nesse concurso, sua banca foi composta pelos professores Juvenal Vieira, Wagner da Cunha, Roldão Lopes de Barros, Antônio de Sampaio Dória, Almeida Júnior e por um beneditino dos Estados Unidos, dom Xavier de Matos. Segundo D'Ávila, os resultados do concurso foram dados pelo professor Fernando de Azevedo, então diretor do Instituto de Educação, na presença do professor Aquiles de Archêro Junior. A nota de d'Ávila foi 6,6, e ele obteve o $2{ }^{\circ}$ lugar no concurso. Nessa ocasião, foi proposta, por Fernando de Azevedo, a livre-docência, porém D'Ávila, em sua entrevista, argumenta que nunca a recebeu.

D'Ávila exerceu ainda os cargos de professor de Didática e de Metodologia do ensino secundário na Faculdade de Filosofia São Bento, de 1933 a 1937, e professor de Psicologia do curso pré-jurídico da Faculdade de Direito de São Paulo, em 1934. Segundo D'Ávila, ele foi lecionar à noite no curso pré-jurídico dessa faculdade, a convite do "doutor Dória”. De 1937 a 1944, atuou como professor de Educação da Escola Normal Livre do Ginásio Ipiranga; foi professor de Português e Literatura no Ginásio Oswaldo Cruz, de 1944 a 1945; foi catedrático de Didática da Faculdade de Filosofia, Ciências e Letras de Campinas, de 1944 a 1945; lecionou no Instituto de Serviço Social, no curso rápido do Serviço Social da Indústria

4 Para esse concurso, ver a tese de D’Ávila (1935). 
(Sesi) e nos cursos técnicos do Serviço Nacional de Aprendizagem Comercial (Senac), de 1946 a 1951. Atuou também como diretor do Serviço de Orientação Pedagógica do Departamento de Educação de São Paulo, de 1938 a 1939; ocupou o cargo de chefe de Orientação Pedagógica do Senac de São Paulo, de 1946 a 1951; foi assistente e depois assessor técnico da Divisão de Ensino do Serviço Nacional de Aprendizagem Industrial (Senai) de São Paulo, de 1952 a 1968; e passou o período de 1954 a 1955 estudando o ensino industrial em diversos países da Europa, como bolsista do Senai e pela Repartição Internacional do Trabalho (RIT).

Foi também presidente do Centro de Estudos "Roberto Mange", do Senai, em São Paulo, de 1956 a 1962; diretor-geral do Departamento de Educação do Estado de São Paulo, de maio a novembro de 1957, durante a gestão de Vicente de Paula Lima como secretário da Educação; membro do Conselho Estadual de Educação, de 1971 a 1973; vice-presidente da Sociedade Paulista de Educação; e fundador e orientador pedagógico do Instituto "Frederico Ozanan", da Sociedade São Vicente de Paula.

Como se pode notar, Antônio D’Ávila atuou em todos os graus do magistério e ocupou importantes cargos na administração escolar. Além dessas atividades, foi membro da comissão de estudos sobre a situação do trabalho dos detentos nos presídios de São Paulo, no governo de Joaquim de Sylos Cintra, entre 7 de agosto de 1962 e 5 de outubro de 1962; representante de São Paulo no Congresso de Educação de Adultos no Rio de Janeiro; representante de São Paulo no Congresso do Ensino Primário em Recife, Goiânia e Belo Horizonte; e membro da comissão executiva do Primeiro Congresso de Educação de Ribeirão Preto. ${ }^{5}$

D’Ávila atuou, ainda, em entidades profissionais e culturais, como a Liga do Professorado Católico, ${ }^{6}$ que lhe concedeu o título

5 Não foi possível localizar, até o momento, as datas em que foram realizados esses congressos ou outras informações adicionais.

6 A Liga do Professorado Católico foi fundada em São Paulo no dia 9 de novembro de 1919. Segundo a publicação Centenário do ensino normal em São Paulo: 1846/1946, a Liga tinha os seguintes objetivos: “a) - Trabalhar pela Religião 
de "Professor do ano" em 1980; o Centro do Professorado Paulista, que lhe outorgou o título de "Professor do ano" em 1971; o Instituto Histórico e Geográfico de São Paulo no seu quadro de sócios-honorários, tendo como patrono o professor João Lourenço Rodrigues e sendo agraciado, por esse Instituto, com o colar D. Pedro I. Além dessas entidades, atuou na Liga do Professorado Paulista, na Academia Paulista de Educação, onde ocupava a cadeira n. 25, tendo como patrono o professor João Toledo; na Academia Paulista de Psicologia, em que foi agraciado com a medalha Wundt; na Academia Paulistana de História, onde recebeu a medalha Clio, tendo como patrono Aureliano Leite; na Academia Brasileira de Literatura Infantil e Juvenil, da qual era presidente quando de seu falecimento e pela qual foi agraciado com a medalha Monteiro Lobato; na Academia Piracicabana de Letras; e na Academia de Letras de Campos do Jordão. Recebeu, ainda, a medalha Brigadeiro Tobias, do Clube dos Estados; foi homenageado em Mirassol (SP) com dois cartões de prata na passagem do 70 o aniversário da cidade, por ter sido, em 1925, o primeiro professor do grupo escolar dessa cidade; recebeu também medalha de ouro e diploma do Conselho Regional de Psicologia por ocasião do Centenário de Psicologia Experimental.

Faz-se notória ainda sua preocupação cívica, à qual o próprio educador faz menção em seu Curriculum vitae e em sua entrevista, além de proferir palestras e ter livros, artigos e capítulos de livros em que trata desse assunto. Em homenagens feitas a Antônio D’Ávila, essa preocupação também é bastante mencionada por outros. Por

Católica Apostólica Romana no seio da classe e difundir o ensino religioso entre os escolares e respectivas famílias; b) - Promover a união da classe, com exclusão absoluta de interêsses partidários ou políticos; c) - Promover o aperfeiçoamento intelectual, moral e religioso de seus membros; d) - Protegê-los, prestigiá-los e defendê-los quando necessário, em público ou particular, na imprensa ou nos tribunais; e) - Representá-los perante as autoridades públicas, pleiteando providências oportunas ou convenientes ao prestígio da classe; f) - Amparar ou socorrer os professores necessitados, facilitando-lhes assistência médica; g) - Dedicar-se de modo especial, à proteção e preservação dos aspirantes ao magistério, do ponto de vista intelectual, moral e religioso" (Rocco, 1946, p.122). 
ocasião da campanha pela Constituição, nos anos de 1931 e 1932, alistou-se com dois irmãos, um dos quais foi atingido por estilhaços de bomba e perdeu o braço esquerdo. Ficou preso por sessenta dias no Presídio de Ilha Grande (SP), onde escreveu um diário relatando os acontecimentos da Revolução de 1930. D’Ávila recebeu a medalha e o diploma MMDC como participante do Movimento Constitucionalista de 1932, no Batalhão Floriano Peixoto.

Observa-se, a partir do exposto, que as atividades do educador Antônio D'Ávila não se limitaram ao ensino e à administração escolar. Ele participou ativamente de entidades profissionais e culturais ligadas à educação e, além disso, destacou-se com diversas publicações, as quais serão apresentadas sinteticamente no tópico a seguir.

\section{Sobre a produção escrita de Antônio d'Ávila7}

No setor editorial, Antônio D'Ávila iniciou suas atividades com uma tradução feita com João Batista Damasco Penna, que foi publicada pela Companhia Editora Nacional (SP) em 1932. ${ }^{8}$ Trata-se de Didática da Escola Nova, de A. M. Aguayo, livro que teve grande repercussão nos espaços educacionais brasileiros. Três anos mais tarde, em 1935, o educador teve publicada sua tese de concurso para o cargo de catedrático de Metodologia do Ensino

7 As referências dos textos que constituem a produção escrita de D'Ávila estão reunidas em Trevisan $(2003 ; 2010)$. As referências da bibliografia de d'Ávila foram ordenadas em seções, de acordo com o tipo de texto, obtendo-se as seguintes quantidades por seção: manuais de ensino, 23; livros didáticos, 23; textos não publicados, 7; capítulos de livros, 3; artigos publicados em periódicos, 78; coluna "Escola pitoresca", 102; coluna "Galeria de patronos de escolas", 65; textos biográficos, 29; conferências e discursos, 20; cotradução, 1; tese de concurso, 1; e entrevista, 1. Até o momento, tem-se um total de 353 referências bibliográficas de textos escritos por Antônio D'Ávila.

8 Essa é a primeira publicação do autor que pude localizar até o momento. Esse exemplar de 1932 foi localizado na biblioteca da Escola Superior de Educação de Lisboa (Esel), em Portugal. 
Primário no Instituto de Educação da Universidade de São Paulo. No ano de 1940, foi publicada, pela Editora Saraiva (SP), a 1aㅡ edição do manual intitulado Práticas escolares: de acordo com o programa de Prática do Ensino do curso normal e com a orientação do ensino primário. ${ }^{9}$ Esse foi o primeiro de uma série de três volumes, os quais atingiram, no total, dezesseis edições, segundo o prefácio escrito pelo autor na 9a edição do volume 1, de 1963. Em 1944, foi publicada a 1a edição do volume 2, e, em 1954, a 1a edição do volume 3 desse manual, os quais também tiveram várias edições e foram publicados pela mesma editora paulista. Além disso, localizei dois exemplares do volume 3 desse manual em Portugal, por meio de pesquisa na internet, sendo um na biblioteca da Escola Superior de Educação Castelo Branco (ESECB) e outro na biblioteca da Escola Superior de Educação de Lisboa (Esel). Esses dados apontam a influência desse educador paulista e a abrangência desse manual, que possivelmente teve circulação nas escolas do magistério primário de Portugal.

Ainda na década de 1940, D’Ávila teve publicados três capítulos de livros, sendo dois em 1946, na publicação Centenário do ensino normal em São Paulo: 1846/1946 (Polianteia comemorativa), e um em 1949, no livro Grandes educadores.

Em 1954, foi publicado o manual intitulado Pedagogia: teoria e prática, pela Companhia Editora Nacional (SP), ${ }^{10}$ e, em 1967, foram publicados os manuais Literatura infanto-juvenil, pela Editora do Brasil (SP), e Pátria brasileira: educação social e cívica: para professores do curso primário e médio e alunos de escola normal, pela Editora Difusora Cultural (SP). Além dos manuais, D’Ávila teve publicados, pela Companhia Editora Nacional, a série de livros didáticos $O$ tesouro da criança, para os quatro graus primários, da qual foram localizados as publicações de 1953 a 1966, e a

9 Para informações mais detalhadas sobre esse manual e seu autor, ver, especialmente, Trevisan (2003; 2009a).

10 Para informações mais detalhadas sobre esse manual, ver, especialmente Trevisan (2007). 
série Alvorada, também destinada aos quatro graus primários, da qual foram localizadas as publicações de 1962 a 1967. (Trevisan, 2003; 2007).

D’Ávila proferiu algumas palestras e conferências, tanto na capital quanto em cidades do interior do estado de São Paulo, abordando especialmente temas sobre educação, moral e civismo. Localizei, até o momento, vinte delas, todas presumivelmente publicadas em diferentes veículos. No entanto, nem sempre pude localizar a data de publicação, assim como o local em que foram proferidas, pois essas referências foram recuperadas do verso da página de rosto de livros do autor e de artigos de jornais. Entre elas, encontram-se: palestra realizada na Escola Normal do Instituto de Educação "Caetano de Campos", em 21 de outubro de 1946, intitulada Edmundo de Amicis: história de uma vida; a conferência Grandes figuras do magistério feminino, realizada no I. E. "Fernando Costa", de Presidente Prudente (SP), em 1953; e o Discurso de posse, no Instituto Histórico e Geográfico de São Paulo (ibidem; 2007).

Em se tratando de artigos em periódicos, sua contribuição foi volumosa. Analisou problemas da educação e divulgou os exemplos de grandes educadores por meio da "Página de Educação" do jornal Diário de S. Paulo, atuou como crítico pedagógico do jornal católico O Legionário e escreveu no jornal O Professor, que, a partir de 1975, passou a intitular-se Jornal dos Professores, uma publicação do Centro do Professorado Paulista (CPP). Sua primeira publicação localizada nesse jornal data de 1965. Escrevia, além de tantos artigos sobre a situação e os problemas educacionais brasileiros, uma coluna intitulada "Escola Pitoresca", com 102 artigos, que passou a ser publicada, presumivelmente, a partir de 1971 - data em que foi encontrada a primeira publicação da coluna -, e 65 biografias de patronos de escolas na coluna intitulada "Galeria de Patronos de Escolas", 11 que teve início em junho de 1980 e terminou em agosto de 1989, com o falecimento de D'Ávila. No total foram escritas 67 biografias, porém duas delas ainda não foram localizadas. D'Ávila

11 Sobre essa coluna, ver Trevisan (2009b) 
foi do corpo redacional do jornal Letras da Província, de Limeira (SP), e da Folha Diocesana, de Patos de Minas (MG). Teve artigos publicados no jornal O Estado de S. Paulo e no Jornal de São Paulo. Escreveu no jornal $O$ Anchieta, órgão da Liga do Professorado Católico, e artigos para a Revista do Instituto Histórico e Geográfico de São Paulo. Publicou também 25 números do periódico intitulado Boletim do Centro de Estudos "Roberto Mange", do Senai, com artigos sobre esse órgão, sobre educação e o ensino industrial, além de publicar biografias e uma tradução. ${ }^{12}$

Na coluna "Galeria de Patronos de Escolas", a primeira publicação trazia o seguinte:

Alimentamos um dia o projeto de organizar um livro, com a vida e a obra de patronos de nossas escolas e, com esse objetivo, recolhemos, pacientemente, dados a respeito, iniciando o levantamento em varias fontes, revistas, jornais e prontuários. Nesse esforço fomos coadjuvados por inúmeros colegas do magistério, de vários pontos do Estado, que nos enviaram, com entusiasmo e presteza, soma riquíssima de biografias. Com todo esse material, nosso e alheio, temos prontas quatro centenas de estudos de patronos, ocasião esta em que nos declaramos gratos aos colegas e amigos que tão pronta e generosamente nos auxiliaram na tarefa. Mais três centenas de biografias estão sendo elaboradas. Temos a esperança de que o livro planejado sairá um dia. E enquanto esperamos por ele, vamos deixando no < Jornal dos Professores> algumas das biografias elaboradas [...]. (D’Ávila, 1980, p.3, destaque no original)

D’Ávila afirma, na primeira publicação da coluna "Escola pitoresca”, que oferecerá periodicamente, pelas colunas desse jornal, alguns dados e algumas notas, referências e anotações do magistério de Asclepíades Aranha. Completa informando que tratará de um

12 Localizei, até o momento, quinze publicações do Boletim do Centro de Estudos "Roberto Mange". 
Memorial que foi "paciente e cuidadosamente redigido" por esse professor. E assim continua:

Daí o trabalho que tomamos de, nestas colunas, recordar número a número do jornal, as ideias da obra, centenas de episódios, fatos, questões de método, coisas pitorescas que se apresentaram na carreira desse mestre, e a que o professor Aranha, que as escreveu, acrescentou finos, graciosos e por vezes profundos comentários, de modo a elucidar temas, a colorir cenas, esclarecer dificuldades, tudo com proveito do ensino e da escola.

Com a liberdade que tive de escolher meu assunto e a de comentar aqui coisas da Escola Pitoresca, tomo hoje, nesta inauguração de coluna, um dos verbetes do Memorial de mestre Aranha e escolho, exatamente, o que êle titulou de Oratória escolar ou Oratória Pedagógica, com um mundo de observações finas e perspicazes, mas que eu, por obséquio do espaço, resumo em duas ou três notas, deixando outras para novas colunas. [...] (idem, 1971, p.8, destaques no original)

Além da coluna mencionada anteriormente, em que D’Ávila escrevia biografias de patronos de escolas, localizei, ainda, 29 textos biográficos, dos quais treze foram publicados em Centenário do ensino normal em São Paulo: 1846/1946 (Polianteia comemorativa), dez foram localizados no Jornal dos Professores, fora da coluna em que biografava patronos de escolas, e seis foram localizados na revista Educação, cujas seções "História da Educação no Brasil” e “Bibliografia” eram assinadas por D’Ávila (Trevisan, 2003).

A seção "História da Educação no Brasil" tinha o objetivo de publicar breves biografias de educadores e de patronos de escolas e informações sobre a vida educacional do país e do estado de São Paulo.

Com o intuito de cultuar nosso passado pedagógico, pela recordação de seus grandes educadores e efemérides notáveis, esta 
"Revista", inicia hoje a publicação de modestos subsídios para a "História da Educação no Brasil". Com esse propósito oferecerá aos leitores, sistematicamente, dados biográficos de nossos grandes educadores, de patronos de escolas e informações interessantes sobre a vida educacional no País e no Estado. Secção de indiscutível valor para o professorado e para quantos se ocupam com assuntos ligados à vida cultural do Brasil aceitará com prazer a colaboração daqueles que lhe quiserem confiar biografia e informes. Assim ficará iniciado um trabalho urgente e sem dúvida meritório, qual o de oferecer à lembrança da geração de hoje as lições e os exemplos dos grandes homens de nosso ensino. (D'Ávila, 1941; 1943, p.161).

Quanto à seção "Bibliografia”, D'Ávila assim explicita seus objetivos e características:

Empenhada em servir o professorado, orientando-lhe a leitura e pondo-o ao par do movimento bibliográfico, esta Secção noticiará, regularmente, o aparecimento de livros de feitio didático, de publicações de carater pedagógico e outros de interesse para o ensino. Ao lado desse noticiário, será feita aqui, com espírito imparcial, breve apreciação das publicações e livros, de modo a orientar o professor na escolha de suas leituras. (idem, 1943, p.184)

No campo da crítica literária e de teses sobre Educação, consta que D'Ávila participou de bancas examinadoras de concursos e que deu vários pareceres sobre o conteúdo de livros e teses, porém não foi possível localizar mais informações sobre o assunto.

A fim de propiciar uma visão de conjunto e uma síntese de suas publicações, são apresentados a seguir, no Quadro 3, distribuídos por ano de publicação, os tipos dos textos escritos por esse educador, publicados entre 1932 (ano de publicação de seu primeiro livro, dentre os localizados até o momento) e 1989 (ano do seu falecimento). 
SUJEITOS DA HISTÓRIA DO ENSINO DE LEITURA E ESCRITA NO BRASIL 207

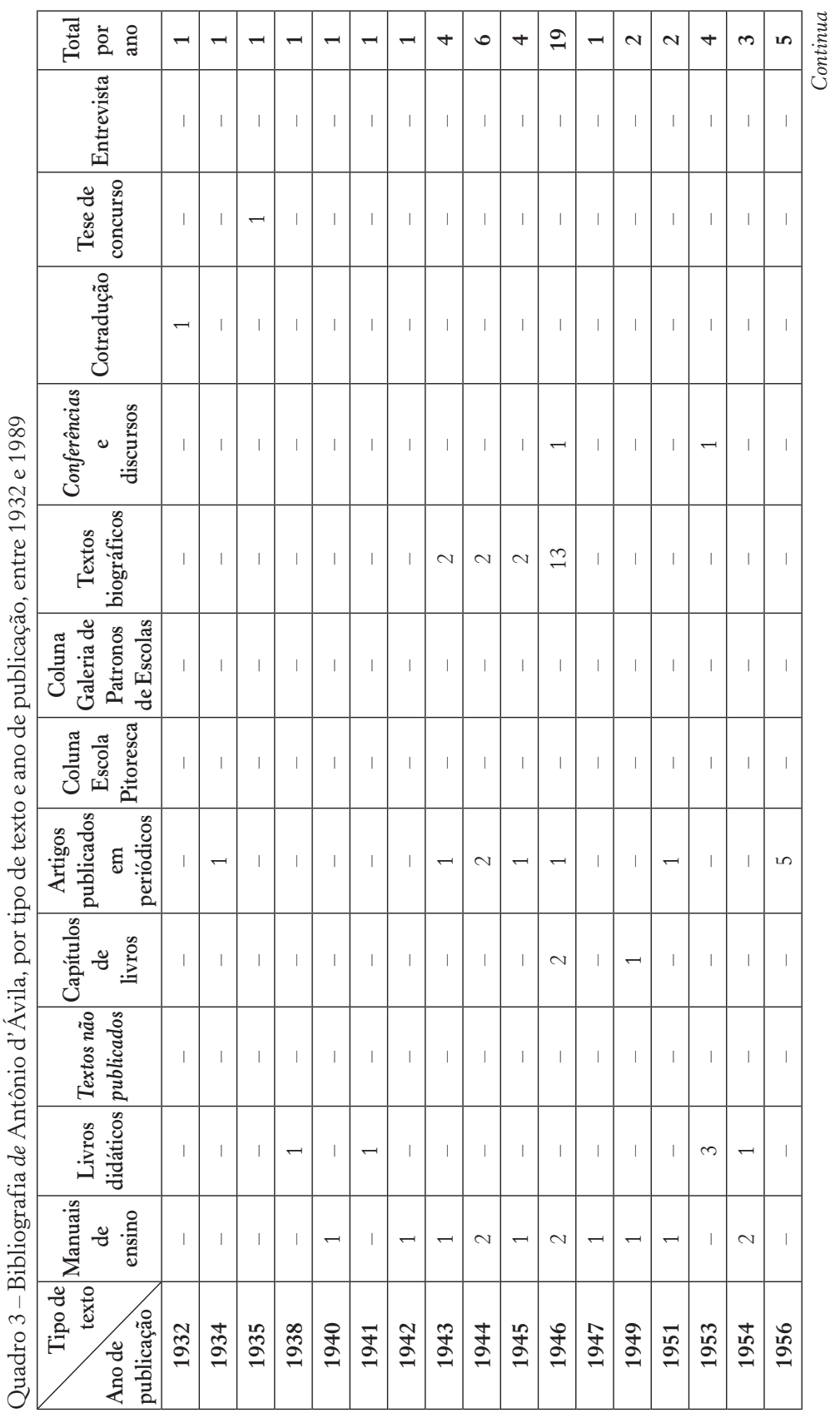




\begin{tabular}{|c|c|c|c|c|c|c|c|c|c|c|c|c|c|c|c|c|c|c|c|}
\hline 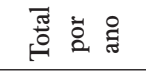 & in & in & + & $\infty$ & in & 0 & $N$ & 0 & $n$ & Ln & - & & -1 & $\stackrel{\mathcal{Z}}{\sim}$ & $\infty$ & $\stackrel{ \pm}{\sim}$ & ㄱ. & $\stackrel{0}{\sim}$ & $\stackrel{\infty}{\sim}$ \\
\hline 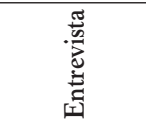 & 1 & 1 & 1 & 1 & 1 & 1 & 1 & 1 & 1 & 1 & 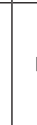 & & 1 & 1 & 1 & 1 & 1 & 1 & 1 \\
\hline 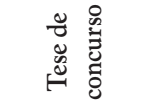 & 1 & 1 & 1 & 1 & 1 & 1 & 1 & 1 & 1 & 1 & 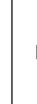 & & 1 & 1 & 1 & 1 & 1 & 1 & 1 \\
\hline 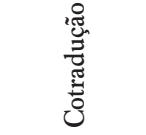 & 1 & 1 & 1 & 1 & 1 & 1 & 1 & 1 & 1 & 1 & 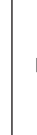 & & 1 & 1 & 1 & 1 & 1 & 1 & 1 \\
\hline 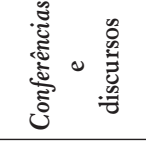 & 1 & 1 & 1 & 1 & 1 & 1 & 1 & 1 & 1 & 1 & 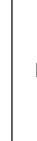 & & 1 & 1 & 1 & 1 & 1 & 1 & I \\
\hline 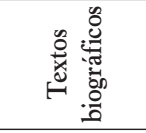 & 1 & 1 & 1 & 1 & 1 & 1 & 1 & - & 1 & 1 & 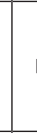 & & -1 & - & 1 & - & $\rightarrow$ & $\rightarrow$ & 1 \\
\hline 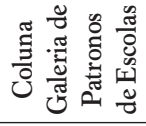 & 1 & 1 & 1 & 1 & 1 & 1 & 1 & 1 & 1 & 1 & 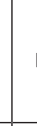 & & 1 & 1 & 1 & 1 & 1 & 1 & 1 \\
\hline 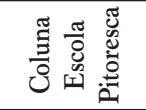 & 1 & 1 & 1 & 1 & 1 & 1 & 1 & 1 & 1 & 1 & 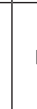 & & 1 & 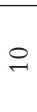 & $\infty$ & $\approx$ & $\stackrel{\infty}{\sim}$ & $\stackrel{2}{\longrightarrow}$ & 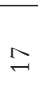 \\
\hline 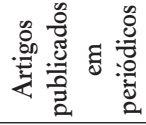 & $m$ & + & $m$ & $m$ & $m$ & 1 & - & $m$ & 1 & 1 & 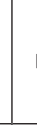 & & 1 & - & 1 & + & - & 1 & - \\
\hline 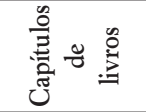 & 1 & I & 1 & 1 & 1 & 1 & 1 & I & 1 & 1 & 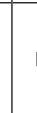 & & 1 & 1 & 1 & 1 & I & 1 & I \\
\hline 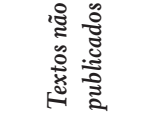 & 1 & 1 & 1 & 1 & 1 & 1 & 1 & - & 1 & 1 & 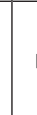 & & 1 & 1 & 1 & $\sim$ & 1 & 1 & 1 \\
\hline 总造 & $N$ & 1 & 1 & 1 & $v$ & in & 1 & 1 & in & $\sim$ & - & & 1 & 1 & 1 & 1 & 1 & 1 & 1 \\
\hline 恚 & 1 & - & - & 1 & 1 & - & - & $\rightarrow$ & $\sim$ & m & 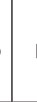 & & 1 & 1 & 1 & 1 & 1 & 1 & 1 \\
\hline 总/ & 20 & 文 & 2ิ & $\stackrel{8}{\circ}$ & 훙 & ชู & ชి & $\stackrel{20}{2}$ & $\stackrel{2}{2}$ & $\approx$ & 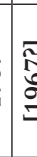 & & مa & 空 & No & $\stackrel{2}{\stackrel{2}{2}}$ & 盇 & 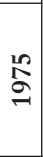 & $\stackrel{2}{2}$ \\
\hline
\end{tabular}




\begin{tabular}{|c|c|c|c|c|c|c|c|c|c|c|c|c|c|c|c|c|c|}
\hline 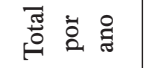 & $\stackrel{\infty}{\sim}$ & $\exists$ & 0 & $\infty$ & $a$ & in & $\stackrel{2}{-}$ & $\infty$ & $\underset{Z}{ }$ & $\infty$ & $\simeq$ & 우 & in & -1 & $\stackrel{2}{\sim}$ & 1 & బొ \\
\hline 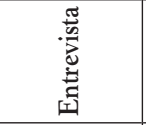 & 1 & 1 & 1 & 1 & 1 & 1 & - & 1 & 1 & 1 & 1 & 1 & 1 & 1 & I & - & \\
\hline 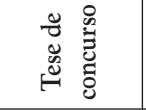 & 1 & 1 & 1 & 1 & 1 & 1 & 1 & 1 & 1 & 1 & 1 & 1 & 1 & 1 & 1 & - & \\
\hline 胥 & 1 & 1 & 1 & 1 & 1 & 1 & 1 & 1 & 1 & 1 & 1 & 1 & 1 & 1 & I & - & \\
\hline 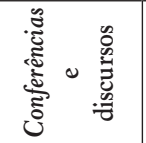 & 1 & 1 & 1 & 1 & 1 & 1 & 1 & 1 & I & 1 & 1 & 1 & 1 & 1 & $\stackrel{\infty}{\sim}$ & 고 & \\
\hline 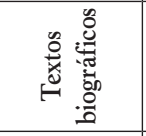 & $\sim$ & 1 & - & 1 & 1 & 1 & - & 1 & 1 & 1 & 1 & 1 & 1 & I & 1 & ปे & \\
\hline 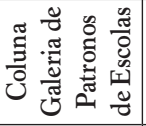 & 1 & 1 & 1 & in & $n$ & in & $n$ & $n$ & $\infty$ & 0 & $r$ & $\infty$ & in & 1 & 1 & 18 & \\
\hline 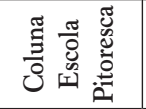 & $\stackrel{0}{-1}$ & -1 & 1 & 1 & 1 & 1 & 1 & 1 & 1 & 1 & 1 & I & I & I & I & ฮิ & \\
\hline 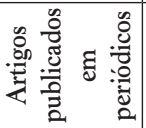 & 1 & $ㅇ$ & in & $m$ & $\sim$ & 1 & -1 & $\rightarrow$ & + & $\sim$ & in & $\sim$ & I & I & + & $\stackrel{\infty}{\wedge}$ & \\
\hline 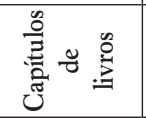 & I & 1 & 1 & 1 & 1 & 1 & 1 & 1 & 1 & 1 & 1 & I & 1 & I & I & $m$ & \\
\hline 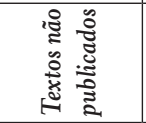 & 1 & 1 & 1 & 1 & 1 & 1 & 1 & 1 & 1 & 1 & 1 & 1 & I & -1 & $m$ & $N$ & \\
\hline 总蒡 & 1 & 1 & 1 & 1 & 1 & 1 & 1 & 1 & 1 & I & 1 & 1 & 1 & 1 & 1 & $\widetilde{\sim}$ & \\
\hline 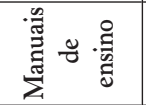 & 1 & 1 & 1 & 1 & 1 & 1 & 1 & 1 & 1 & I & 1 & 1 & 1 & 1 & 1 & $\ddot{\sim}$ & \\
\hline 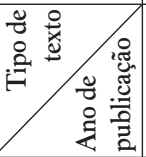 & N & 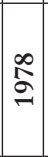 & 尽 & $\begin{array}{l}\stackrel{\circ}{\mathscr{D}} \\
\stackrel{\sigma}{\sigma}\end{array}$ & $\stackrel{\vec{\infty}}{\sigma}$ & $\begin{array}{c}1 \\
\mathscr{\sigma} \\
\sigma\end{array}$ & $\begin{array}{c}0 \\
2 \\
2\end{array}$ & 志 & $\begin{array}{l}1 \\
\infty \\
2 \\
=\end{array}$ & 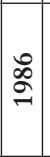 & $\begin{array}{l}1 \\
\stackrel{\infty}{=} \\
\sigma\end{array}$ & \begin{tabular}{l}
$\infty$ \\
$\infty$ \\
\hdashline
\end{tabular} & 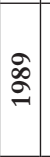 & $\stackrel{\infty}{2}$ & $\begin{array}{l}T \\
\text { O } \\
\Xi\end{array}$ & 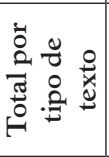 & 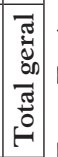 \\
\hline
\end{tabular}


No Quadro 3, a quantidade de publicações por ano refere-se às edições que pude localizar de cada título de livro referenciado. Sendo assim, ressalto que nem sempre apresento a referência da primeira edição de um determinado título do autor. No caso, por exemplo, do primeiro volume do manual Práticas escolares, foi possível localizar a data de publicação da $1 \underline{a}$ edição, mas isso não ocorreu com todas as publicações do autor; foram referenciados, em separado, cada volume dos livros localizados, assim como as várias edições, mesmo as que foram revistas, melhoradas e/ou ampliadas; todas as conferências foram incluídas no quadro apresentado, mesmo aquelas em relação às quais não foi possível precisar a data de publicação e/ou realização. A seção de "Artigos publicados em periódicos" está apresentada e referenciada separadamente das duas colunas escritas por D'Ávila, apesar de essas três seções serem todas publicações localizadas em periódicos. Optei por apresentá-las e referenciá-las dessa forma porque somam um conjunto expressivo de publicações e também porque assim é possível destacá-las do conjunto. A seção de textos biográficos também está apresentada no Quadro 3 separadamente do conjunto de biografias elaboradas pelo educador para a coluna "Galeria de Patronos de Escolas”, textos também biográficos. Tais separações são uma forma de dar ênfase às colunas publicadas no Jornal dos Professores e aos textos biográficos escritos pelo autor, bem como ao período dessas publicações.

No Quadro 3 observa-se que o maior número de publicações do autor está concentrado nas décadas de 1970 (134) e 1980 (88). Na década de 1970, a maioria das publicações (ou seja, 102) é da coluna "Escola pitoresca". As publicações em periódicos percorrem todo o período (de 1932 a 1989), sendo que o maior número de publicações desse tipo de texto concentra-se na seção "Artigos publicados em periódicos" e na coluna "Escola pitoresca”, na década de 1970 (22 e 102, somando um total de 124 artigos). Na década de 1980, foram publicados também na seção "Artigos publicados em periódicos" e na coluna "Galeria de Patronos de Escolas" (20 e 65, somando um total de 85 artigos), como se pode observar no Quadro 3. 
Conclui-se, portanto, que o maior número de publicações de D'Ávila concentra-se em periódicos, principalmente se somadas a esse tipo de texto a coluna "Escola pitoresca", com 102 artigos, e a coluna "Galeria dos Patronos de Escolas", com 65 artigos. Ambas são publicadas no periódico Jornal dos Professores.

As publicações desse autor em livros, ou seja, manuais de ensino (23), livros didáticos (23) e capítulos de livros (3), concentram-se nas décadas de 1940, 1950 e 1960. Essas publicações não representam, em números, nem a metade das publicações em periódicos (245). Não foram localizados livros publicados por D’Ávila nas décadas de 1970 e 1980. A década de 1930 é a que possui menor número de publicações desse educador, havendo no total, considerando o ano e todos os tipos de texto, apenas quatro. Os tipos de texto que apresentam a menor quantidade de publicações (um) são: cotradução, tese de concurso e entrevista. Observa-se, ainda, que dezoito das vinte "Conferências e Discursos" apresentam-se sem data precisa [19--].

Posso destacar, ainda, a partir do Quadro 3, uma característica desse educador: sua dedicação à escrita de biografias. Somando-se a coluna "Galeria de Patronos de Escolas" à seção "Textos biográficos", chega-se a 94 biografias. Apenas com data de publicação nas décadas de 1930 e 1950 não foi localizado nenhum texto desse tipo. A esse respeito, pode-se pensar que o educador considerava muito importante oferecer ao professorado, principalmente em formação, bons modelos em que espelhar-se e que pudessem ser seguidos.

As publicações de D'Ávila permitem, ainda, constatar sua significativa produção escrita, a qual expressa, entre outros importantes aspectos, seu compromisso e sua preocupação com a formação de professores no Brasil, especialmente os de nível primário, no terceiro momento da história da alfabetização no Brasil (Magnani, 1997; Mortatti, 2000)

No que se refere à bibliografia sobre D’Ávila, localizei 36 referências bibliográficas de textos escritos por outros autores em que há citações da e sobre a produção escrita de Antônio D’Ávila, men- 
ções e homenagens a esse educador e informações sobre sua vida e atuação profissional.

Em ordem cronológica crescente de publicação, apresento algumas referências que foram localizadas: um texto na revista $E d u$ cação, de 1934, em homenagem ao professor Antônio D'Ávila, cujo título é "A mão humana"; uma síntese do manual Práticas escolares, publicada em 1944 na revista Educação, na seção "Bibliografia”, e assinada por L. de A.; um verbete sobre D'Ávila no Dicionário de autores paulistas, (Melo, 1954); dois artigos de jornal, de 1963, anunciando que a aula inaugural no Instituto de Educação de Birigui (SP) seria ministrada pelo professor Antônio D’Ávila e apresentando dados biográficos desse educador; uma referência ao educador em subtópico intitulado "Coração, de Edmundo de Amicis", constante de capítulo de livro publicado em 1974; uma palestra sobre D'Ávila proferida no Instituto Histórico e Geográfico de São Paulo, após sua morte, em 1989, por Roberto Machado Carvalho; referência ao manual Práticas escolares, em Magnani (1997) e Mortatti (2000); algumas referências sobre D’Ávila e sua obra em um estudo a respeito da história de leituras para professores, de Silva (2001; 2005); três estudos que tratam específica e pontualmente a respeito desse educador e de sua obra, em Trevisan (2003; 2007) e Dias (2006); e três artigos, um de Valdemarin (2008) e dois de Trevisan (2009a; 2009b). Além desses textos, existem outros que fazem parte de um conjunto de referências de e sobre o educador Antônio D'Ávila e que estão organizadas sinteticamente nos quadros apresentados nesse texto.

Com o intuito de oferecer uma melhor visualização e também uma síntese das publicações sobre Antônio D'Ávila, apresenta-se, no Quadro 4, as referências dos textos de D'Ávila distribuídas por ano de publicação, quantidade e tipos de textos, todos eles publicados entre 1934 e 2010.

No Quadro 4, observa-se que as publicações de maior número sobre o autor são as que se encontram na seção "Artigos em periódicos" (treze) e as da seção "Homenagem" (doze). Destaco ainda que nas décadas de 1970 e 1980 concentra-se a maior quantidade de 
Quadro 4 - Bibliografia sobre Antônio D’Ávila, por tipo de texto e ano de publicação, entre 1934 e 2010

\begin{tabular}{|c|c|c|c|c|c|c|}
\hline $\begin{array}{r}\text { Tipo de } \\
\text { texto }\end{array}$ & $\begin{array}{c}\text { Verbete } \\
\text { em } \\
\text { dicionário }\end{array}$ & Homenagem & $\begin{array}{l}\text { Trabalhos } \\
\text { científicos } \\
\text { (TCC, } \\
\text { dissertação e } \\
\text { tese) }\end{array}$ & $\begin{array}{c}\text { Artigos } \\
\text { em } \\
\text { periódicos }\end{array}$ & $\begin{array}{c}\text { Citação } \\
\text { em livro } \\
\text { e capítulo } \\
\text { de livro }\end{array}$ & $\begin{array}{l}\text { Total } \\
\text { por } \\
\text { ano }\end{array}$ \\
\hline 1934 & - & 1 & - & - & - & 1 \\
\hline 1944 & - & - & - & 1 & - & 1 \\
\hline 1950 & - & - & - & 2 & - & 2 \\
\hline 1954 & 1 & - & - & - & - & 1 \\
\hline 1956 & - & - & - & 1 & - & 1 \\
\hline 1958 & - & - & - & 1 & - & 1 \\
\hline 1962 & - & 1 & - & - & - & 1 \\
\hline 1963 & - & - & - & 2 & - & 2 \\
\hline 1971 & - & 1 & - & - & - & 1 \\
\hline 1973 & - & 2 & - & - & - & 2 \\
\hline 1974 & - & - & - & - & 1 & 1 \\
\hline 1979 & - & - & - & 1 & - & 1 \\
\hline 1980 & - & 1 & - & - & - & 1 \\
\hline 1981 & - & 1 & - & - & - & 1 \\
\hline 1983 & - & 2 & - & - & - & 2 \\
\hline 1989 & - & 2 & - & 1 & - & 3 \\
\hline 2001 & - & - & 1 & - & - & 1 \\
\hline 2003 & - & - & 1 & - & - & 1 \\
\hline 2004 & - & - & - & - & 1 & 1 \\
\hline 2005 & - & - & 1 & - & - & 1 \\
\hline 2006 & - & - & 1 & - & - & 1 \\
\hline 2007 & - & - & 1 & - & - & 1 \\
\hline 2008 & - & - & - & 1 & - & 1 \\
\hline 2009 & - & - & 1 & 2 & - & 3 \\
\hline 2010 & - & - & 1 & - & 1 & 2 \\
\hline [19--] & - & 1 & - & 1 & - & 2 \\
\hline $\begin{array}{c}\text { Total por } \\
\text { tipo de } \\
\text { texto }\end{array}$ & 1 & 12 & 7 & 13 & 3 & - \\
\hline total geral & & & & & & 36 \\
\hline
\end{tabular}

Fonte: Trevisan (2003; 2007). 
publicações sobre Antônio D’Ávila, sendo sete publicações na década de 1980 e cinco na década de 1970. Três publicações da década de 1970 e seis da década de 1980 correspondem a homenagens feitas ao educador, e nota-se que duas dessas publicações da década de 1980 fazem referência ao falecimento do educador. Na década de 1950, observam-se cinco publicações, sendo quatro "Artigos em periódicos" e um "Verbete em dicionário". No período de 2001 a 2010 têm-se sete textos, que se referem a "Trabalhos científicos", três deles tratando específica e pontualmente a respeito de D'Ávila e um manual selecionado de sua produção escrita, e quatro são apenas menções ao autor e/ou a sua produção bibliográfica. O menor número de publicações localiza-se em 1934 e em 1944 (ambos com apenas uma publicação).

\section{Considerações finais}

Mediante comparação entre as publicações apresentadas do autor e sobre o autor, observa-se a significativa produção intelectual de Antônio D’Ávila que se encontra, ainda, pouco explorada, sugerindo várias possibilidades de estudo, como as sugeridas em Magnani (1997) e Mortatti (2000), matriz teórica das pesquisas de que resultou este texto e as apresentadas, por exemplo, em Trevisan (2003; 2007) e Dias (2006).

Antônio D’Ávila, portanto, trabalhou mais de cinquenta anos de sua vida com questões ligadas à educação, inclusive atuando no magistério, conforme ressaltam os textos escritos em sua homenagem. Ora trabalhou como professor, ora como administrador, outras vezes como estudioso das questões educacionais, sendo seus estudos transformados em livros, em colunas e artigos para jornais e revistas e em conferências. Enfim, de muitas formas colaborou D’Ávila com a educação e com a formação do magistério do país.

Sua atuação não ficou limitada à capital paulista. O educador percorreu o interior do estado proferindo suas conferências e palestras e atuou como membro do Conselho Estadual de Educação, como diretor do Departamento de Educação do Estado de São 
Paulo, presenciando a inauguração de Institutos de Educação, e mesmo por intermédio da sua produção escrita. Textos de homenagem relatam que D'Ávila teve uma formação sólida, inclusive familiar e religiosa. Conviveu com educadores como Lourenço Filho, Sampaio Dória, Almeida Junior, Fernando de Azevedo e outros. Uma característica bastante comum dos textos biográficos escritos por D’Ávila é o enaltecimento do biografado. Essa característica também se manteve nas biografias elaboradas sobre ele, como no caso de Carvalho (1989, p.8), que descreve D’Ávila como alguém que "[...] sempre se colocou na vanguarda de todos os movimentos que visassem aperfeiçoar o ensino e a educação entre nós, em todos os níveis, mormente o primário".

Nesse sentido, este texto pode contribuir, entre outras questões, com uma melhor explicitação do papel desse educador e do impacto de sua produção escrita no campo educacional paulista, e até mesmo avaliar se ele, de fato, estava na vanguarda ou não.

Em homenagem póstuma, Carvalho (ibidem, p.8) ainda diz textualmente sobre D'Ávila:

Idealista ao extremo e dotado daquelas qualidades morais, cívicas e intelectuais que ornamentam a personalidade do autêntico educador [...] honrou com sua proveitosa existência as mais nobres tradições da instrução e educação de nossas crianças e jovens.

Essas qualidades a que Carvalho (ibidem) se refere ficaram marcadas nas biografias e demais documentos aqui utilizados para entender a trajetória de D’Ávila e podem ser observadas em todas suas publicações, desde seus artigos de jornais e livros até suas palestras e conferências. D’ Ávila “[...] considerava a moral e o civismo, dois pilares de sustento de nossas aspirações democráticas e fundamentais para a formação de cidadãos conscientes de seus deveres e direitos" (ibidem, p.8).

Estudioso, desde os bancos escolares dos problemas da Educação, soube, com inteligência, competência e firmeza, apresentar 
ao longo dos anos, magníficas teses, escritas e divulgadas, com o nobre objetivo de oferecer aos educadores e responsáveis, o que apareceu de melhor entre nós, em matéria de pedagogia, psicologia, metodologia de ensino e administração escolar (ibidem, p.8).

Da trajetória profissional de D'Ávila é possível destacar também sua atuação em repartições públicas e particulares, no ensino e na administração. Além disso, pode-se observar uma participação relevante do educador em instituições católicas, como professor e como colaborador na escrita de artigos para periódicos. Fica evidente a formação religiosa católica de D’Ávila, formação essa que também se fez presente em sua vida profissional e em sua produção escrita.

É possível pensar em Antônio D’Ávila, ainda por meio de sua trajetória e produção escrita, como um intelectual ativo nos movimentos educacionais, como o da Escola Nova, e políticos, como o movimento constitucionalista de 1932. Esse educador, porém, não se apresenta como linha de frente dos movimentos, ou seja, assinando documentos, ou como dirigente de alguma dessas associações em que os grupos se aglutinavam. Na verdade, D'Ávila, assim como ficou evidenciado no estudo feito a respeito do manual Práticas escolares (Trevisan, 2003) e também do manual Pedagogia: teoria e prática (idem, 2007), foi propagador de uma didática escolanovista. Ele representava um movimento que se dizia a favor da Escola Nova e, portanto, auxiliava na divulgação e propagação desses preceitos, por meio de seus artigos em periódicos, livros, traduções, de suas atividades como professor e das funções administrativas que exerceu.

E é também possível constatar a importância de Antonio D’Ávila no âmbito da produção de manuais didáticos, no terceiro momento da história da alfabetização no Brasil. Em seus manuais, apresenta também propostas para o ensino da leitura e escrita, tendo contribuído decisivamente tanto para a divulgação dos princípios esolanovistas para o ensino de leitura e escrita quanto para a sedimentação de um corpo de saberes necessários para a formação do professor responsável por esse ensino. 


\section{Referências bibliográficas}

A DIRETORIA. I. E. "Prof. Stélio Machado Loureiro" de Birigui. A Verdade, Birigui, ano 18, n. 898, p.5, 24 fev. 1963.

BERTOLETTI, E. N. M. Cartilha do povo $e$ Upa, cavalinho!: o projeto de alfabetização de Lourenço Filho. Marília, 1997. 129f. Dissertação (Mestrado em Educação) - Universidade Estadual Paulista.

A produção de Lourenço Filho sobre e de literatura infantil e juvenil (1942-1968): fundação de uma tradição. Marília, 2006. 275f. Tese (Doutorado em Educação) - Faculdade de Filosofia e Ciências, Universidade Estadual Paulista.

BOURDIEU, P. A Ilusão Biográfica. In: Razões práticas: sobre a teoria da ação. 3.ed. São Paulo: Papirus, 2001, p.74-82.

CARVAlHO, R. M. Professor Antônio D’Ávila. Jornal dos Professores, São Paulo, p.8, out.-nov. 1989.

CATANI, D. B. . Educadores à meia-luz: um estudo sobre a Revista de Ensino da Associação Beneficente do Professorado Público de São Paulo: 1902-1918. São Paulo, 1989. Tese (Doutorado) - Faculdade de Educação, Universidade de São Paulo, São Paulo.

Ensaios sobre a produção e circulação dos saberes pedagógicos. São Paulo, 1994. Tese (Livre-Docência) - Faculdade de Educação, Universidade de São Paulo.

D'ÁVILA, A. As modernas directrizes da didactica. Monographia apresentada para o concurso de Methodologia do Ensino Primario na Escola de professores da Universidade de São Paulo. São Paulo: Typ. Ideal Heitor L. Canton, 1935. 198p.

História da Educação no Brasil. Revista de Educação, São Paulo, v.29, n.30/39, p.187-8, mar. 1941; jun. 1943.

. Bibliografia. Revista de Educação, São Paulo, v.30, p.184-6, jul.-dez. 1943.

. Escola Pitoresca. O professor, São Paulo, fev. 1971. p. 8.

. Galeria de patronos de escolas (I). Jornal dos Professores, São Paulo, p.3, jun. 1980.

Projeto Memória da Psicologia brasileira: depoimento n. 3 [jun. 1983]. Entrevistadores: Carlos Corrêa Mascaro e Valério Giuli. São Paulo: Stúdio de som do Museu da Imagem e do Som, 1983. 2 cassetes sonoros. Entrevista concedida ao Programa de História Oral da Psicologia brasileira realizada em colaboração com o Arquivo do estado de São Paulo e a Academia Paulista de Psicologia. 
Curriculum Vitae. [S.1.: s.n.], [19--]. Não publicado.

DIAS, M A. Um estudo sobre O tesouro da criança, de Antônio d'Ávila (1965). Marília, 2006. 64f. Monografia (Trabalho de Conclusão de Curso de Pedagogia) - Faculdade de Filosofia e Ciências, Universidade Estadual Paulista.

MAGNANI, M. do R. M. Os sentidos da alfabetização: a "questão dos métodos" e a constituição de um objeto de estudo (São Paulo 1876/1994). Presidente Prudente, 1997. 389f. Tese (Livre-Docência em Metodologia do Ensino de 1ํGrau: Alfabetização) - Faculdade de Ciências e Tecnologia, Universidade Estadual Paulista.

MELO, L. C de. Dicionário de autores paulistas. São Paulo: [s.n.], 1954, p.182-3. (Comissão do IV centenário da cidade de São Paulo).

MORTATTI, M. do R. L. Os sentidos da alfabetização: São Paulo/18761994. 1.ed. São Paulo: Editora Unesp, 2000.

O PROF. Antonio D'Ávila proferirá a aula inaugural do Instituto de Educação. O Biriguiense, Birigui, ano 32, n.1691, 24 fev. 1963.

REDAÇÃ̃O. Editorial. Educação, São Paulo, v.31, n. 42/43, jan.-jun. 1944. REVISTA do Professor, São Paulo, ano 20, n.70, out.-dez. 1962.

ROCCO, S. (org.). Centenário do ensino normal em São Paulo: 1846/1946. Polianteia: São Paulo: Gráfica Bréscia, 1946, p.122-4. (Polianteia comemorativa...).

SILVA, V. B. da. História de leituras para professores: um estudo da produção e circulação de saberes especializados nos "manuais pedagógicos" brasileiros (1930-1971). São Paulo, 2001. 213f. Dissertação (Mestrado em Educação) - Faculdade de Educação, Universidade de São Paulo.

Saberes em viagem nos manuais pedagógicos: construções da escola em Portugal e no Brasil (1870-1970). São Paulo, 2005. 400f. Tese (Doutorado em Educação) - Faculdade de Educação, Universidade de São Paulo.

TREVISAN, T. A. Um estudo sobre Práticas escolares (1940), de Antônio d'Ávila. Marília, 2003. 66f. Trabalho de Conclusão de Curso (Graduação em Pedagogia) - Faculdade de Filosofia e Ciências, Universidade Estadual Paulista.

A Pedagogia por meio de Pedagogia: teoria e prática (1954), de Antônio D'Ávila. Marília, 2007. 165f. Dissertação (Mestrado em Educação) - Faculdade de Filosofia e Ciências, Universidade Estadual Paulista.

. O ensino da leitura e escrita segundo Antônio D'Ávila: Práticas escolares (1940). Revista Brasileira de História da Educação, n.20, p.165-91, maio-ago. 2009a. 
O cultivo de valores exemplares: "Galeria dos Patronos de Escolas”, de Antônio D'Ávila (1980-1989). História da Educação, ASPHE/FaE/UFPel, Pelotas, v.13, n.27, p.191-209, jan.-abr. 2009b. VALDEMARIN, V. O manual didático Práticas escolares: um estudo sobre mudanças e permanências nas prescrições para a prática pedagógica. Revista Brasileira de História da Educação, [s.1.], n.17, p.13-39, maio-ago. 2008.

VILELA, M. C. Deixar falar a "Educação": escuta de um discurso pedagógico. São Paulo, 1997. Dissertação (Mestrado em Educação) - Pontifícia Universidade Católica.

Discursos, cursos e recursos: autores da revista "Educação" (19271961). São Paulo, 2000. Tese (Doutorado em Educação) - Pontifícia Universidade Católica.

VILELA, M. C. et al. Estudo de periódicos: possibilidades para a História da Educação Brasileira. In: MENEZES, M. C. (org.). Educação, memória, história: possibilidades, leituras. Campinas: Mercado de Letras, 2004, p.401-50. 


\section{2 \\ Bárbara V. de Carvalho \\ (1915-2008) NA HISTÓRIA DO ENSINO DA LITERATURA INFANTIL ${ }^{1}$}

Fernando Rodrigues de Oliveira

\section{Introdução}

No Brasil, desde que a literatura infantil constituiu-se como gênero literário, entre o final do século XIX e início do século XX, e tornou-se um dos principais e mais rentáveis ramos editoriais do país, como apontam Magnani (1997) e Mortatti (2000a), também os estudos e pesquisas sobre esses livros começaram a crescer em proporções aceleradas.

No entanto, embora a produção acadêmico-científica brasileira sobre literatura infantil encontre-se, hoje, em quantidade significativa e bastante diversa, o que se observa é que alguns temas e autores ainda permanecem relegados ao "esquecimento" dos que se ocupam da investigação nesse campo de conhecimento.

Esse era o caso, por exemplo, da professora e escritora baiana Bárbara Vasconcelos de Carvalho (1915-2008), cuja atuação profissional e produção escrita deixaram marcas significativas na história da literatura infantil e em seu ensino na formação de professores.

1 Este texto é resultante de pesquisa de mestrado, desenvolvida com bolsa Fapesp, cujos resultados finais foram apresentados sob a forma de dissertação de mestrado (Oliveira, 2010). Com adequações de redação, a dissertação foi publicada em livro (idem, 2013). Artigo com conteúdo semelhante encontra-se em Oliveira (2011b) [N.O.]. 
A atuação e a produção escrita dessa professora encontram-se relacionadas com as discussões características do terceiro momento da história da alfabetização (Magnani, 1997; Mortatti, 2000).

Nesse momento sistematiza-se a produção, por brasileiros, de material didático destinado à utilização em cursos de formação de professores (Mortatti, 2000). Assim como ocorreu com as cartilhas de alfabetização no início do século XX e com os manuais de ensino, a partir de 1930, também a produção didática de Bárbara Vasconcelos de Carvalho origina-se de suas bem-sucedidas experiências como professora e relaciona-se diretamente com a criação da disciplina "Literatura infantil" nos cursos de formação de professores no estado de São Paulo (Oliveira, 2013).

Tendo em vista esses aspectos, busco, neste texto, compreender o lugar ocupado por Bárbara Vasconcelos de Carvalho na história do ensino da literatura infantil na formação de professores no Brasil e compreender as influências recebidas e exercidas por ela nessa história. Para tanto, apresento aspectos da atuação profissional e produção escrita dessa professora e escritora, bem como aspectos da produção escrita sobre ela. Sua produção e atuação profissional permitem situá-la, também, como importante sujeito da história do ensino de leitura, para o qual ela contribuiu com materiais, respondendo a urgências e necessidades educacionais do terceiro momento da história do ensino de leitura e escrita no Brasil (Magnani, 1997; Mortatti, 2000a).

\section{Bárbara V. de Carvalho: uma baiana influente na educação paulista ${ }^{2}$}

Nascida no dia 5 de novembro de 1915, na cidade de Alagoinhas (BA), Bárbara Isabel Vasconcelos realizou seus estudos primários e

2 As informações contidas neste tópico foram localizadas em documentos que pertencem ao acervo pessoal de Bárbara Vasconcelos de Carvalho, em documentos que localizei na Escola Estadual "Jácomo Stávale" e na Escola Estadual "Dr. Manuel José Chaves", em Coelho (2006), em Carvalho (2010) e em Santos (2010). 
formou-se professora na cidade de Salvador (BA), onde, na realidade, teve seu nascimento registrado.

Filha caçula de Pedro Silva Vasconcelos e Alice Alves Vasconcelos, Bárbara Isabel Vasconcelos, durante a infância, frequentou a antiga Escola Reunida dos Mares, atual Escola Estadual "Castro Alves", em Salvador. Porém, em decorrência de seu ingresso tardio nessa escola, ela autoalfabetizou-se antes mesmo de ter sido matriculada na escola primária.

Após concluir os estudos primários e secundários, aos 18 anos de idade, em 1933, Bárbara Isabel Vasconcelos iniciou o Curso Normal no Instituto Normal da Bahia e diplomou-se professora, em 1936, pelo Colégio "Nossa Senhora da Soledade".

No mesmo ano em que se formou professora, em maio de 1936, casou-se com Aurivaldo Farias de Carvalho, recém-formado médico cirurgião, a partir de quando passou a assinar Bárbara Vasconcelos de Carvalho. Com seu casamento seguidamente à sua formação como professora, Bárbara V. de Carvalho não iniciou sua atuação profissional, tendo isso ocorrido somente no ano de 1943, após ter ficado precocemente viúva.

O primeiro trabalho de Bárbara V. de Carvalho foi como professora do Instituto Normal da Bahia, em Salvador, onde lecionou Língua Portuguesa entre os anos de 1943 e 1952. Presumivelmente ainda atuando no Instituto Normal da Bahia, em Salvador, no ano de 1947, foi aprovada em concurso para o cargo de professora efetiva de Língua Portuguesa do Colégio Estadual da Bahia, onde permaneceu até 1952. Entre os anos de 1948 e 1949, ensinou Língua Portuguesa no Colégio "Carneiro Ribeiro” e no Ginásio de Itapagipe, todos em Salvador.

Devido a sua atuação nessas instituições, Bárbara V. de Carvalho teve emitidos, a seu pedido, atestados manuscritos sobre a "capacidade" que demonstrou como professora de Língua Portuguesa dessas diferentes instituições, como é o caso do atestado emitido pelo inspetor federal do Colégio Estadual da Bahia, Maerbal Marinho, em 24 de janeiro de 1949: 
Atesto, com a mais viva satisfação, e dentro dos mais rigorosos princípios de justiça, que, diante da época em que a requerente regeu turmas por mim inspecionadas no Colégio Estadual da Bahia, sempre lhe observei [...] viva dedicação pelo ensino, seja pela assiduidade às aulas, quer pela maneira metódica e racional de desenvolver os programas oficiais, seja, ainda, pela competência que, ao meu ver, sempre revelou. A luz dessas observações, cumpro, pois, em dever de justiça, em reconhecendo na Prof ${ }^{a}$. Bárbara Vasconcelos de Carvalho um dos expoentes positivos da atual geração docente, que conheço. (Marinho, 1949, n.p.)

Mesmo tendo atuado em todas essas instituições, ainda devido a sua viuvez precoce, essa professora atuou como escritora de crônicas para a Rádio Sociedade de Salvador, com o propósito de aumentar sua renda.

Concomitantemente a sua atuação como professora, em 1945, Bárbara V. de Carvalho foi aprovada no exame para ingresso no curso de Letras Neolatinas da Faculdade de Filosofia da Universidade da Bahia, tendo-se diplomado, em 1949, bacharel e licenciada em Letras.

Após concluir o curso de Letras, em 1952, mudou-se para o Rio de Janeiro, então Distrito Federal, para participar de um curso de especialização sobre Literatura Portuguesa e Brasileira junto à Faculdade de Filosofia da Universidade do Brasil, curso que não concluiu. Na realidade, inicialmente, ela foi convidada para fazer curso no exterior, porém, como à época suas filhas eram ainda crianças, optou por dar continuidade aos seus estudos no Rio de Janeiro, onde permaneceu apenas por alguns meses (Carvalho, 2010).

Nesse período em que residiu no Rio de Janeiro, Bárbara V. de Carvalho conheceu a cidade de São Paulo, onde prestou concurso para o cargo de professora secundária de Língua Portuguesa, tendo sido aprovada, em 1953. Assim, ela assumiu, na capital de São Paulo, o cargo de professora de Língua Portuguesa, em 29 de julho de 1953, no Colégio "Franklin Roosevelt", onde permaneceu por seis meses, tendo seu cargo sido removido para diferentes escolas em diferentes cidades do interior do estado. 
No período em que atuava em uma escola do interior do estado - no Ginásio Estadual de Valparaíso -, Bárbara V. de Carvalho, em 1957, foi convidada a instalar e dirigir o Ginásio Estadual de Vila Formosa, na capital de São Paulo. Ela permaneceu nesse cargo até o final do ano de 1957, quando voltou a lecionar Língua Portuguesa no Ginásio Estadual e Escola Normal "Jácomo Stávale”, também na capital de São Paulo.

Ainda durante o ano de 1957, enquanto atuava como diretora do Ginásio de Vila Formosa, “[...] coordenou a equipe responsável pela reformulação dos programas de Português do Curso Pedagógico, quando apresentou projeto e introduziu o ensino da literatura infantil nos programas do referido Curso [...]" (Santos, 2001, p.45). Essa atividade proporcionou-lhe visibilidade e destaque no campo educacional paulista, especialmente no que se refere ao ensino de literatura infantil.

Após firmar sede no Ginásio Estadual e Escola Normal "Jácomo Stávale" e ter coordenado a equipe responsável pela reformulação dos programas de Língua Portuguesa, Bárbara V. de Carvalho passou a ser convidada para ministrar cursos e palestras sobre literatura infantil para professores e professorandos, como o curso sobre literatura infantil ministrado na Biblioteca Infantil "Monteiro Lobato", em Salvador (BA); o curso de extensão intitulado "Panorama Geral da Literatura infantil", no Colégio Estadual e Escola Normal "Prof. Paula Santos", em Salto (SP); e o curso de férias sobre literatura infantil para os professores da Delegacia de Ensino Elementar da região de Santos (SP).

Além dos convites para ministrar cursos, Bárbara V. de Carvalho também passou a ser convidada para ocupar cargos e exercer funções em diferentes órgãos/departamentos do executivo paulista, como: as designações para atuar como membro da banca de elaboração dos exames unificados de madureza para $1^{\circ}$ e e $2^{\circ}$ ciclos; a designação para integrar o grupo assessor de Teatro Infantil, junto à Comissão Estadual de Teatro, do Conselho Estadual de Cultura do estado de São Paulo; e a designação para participar da comissão do concurso literário "Luís de Camões", promovido pelo Departa- 
mento de Educação da Secretaria de Estado dos Negócios da Educação do estado de São Paulo.

Concomitantemente a essa atuação, durante a década de 1960, Bárbara V. de Carvalho passou a atuar como professora de Literatura Brasileira junto à Faculdade de Filosofia "Nossa Senhora do Patrocínio", em Itu (SP), tendo permanecido na função até 1972.

No início da década de 1970, devido à atuação que vinha tendo no magistério público paulista, Bárbara V. de Carvalho foi convidada para atuar como assessora junto ao gabinete da secretária de Educação do estado de São Paulo, Esther de Figueiredo Ferraz, tendo-se afastado para essa atividade em 30 de outubro de 1971. Em nota publicada no jornal Última hora, de 4 de janeiro de 1972, consta a seguinte informação:

Bárbara Vasconcelos de Carvalho, professora de Português e Literatura, agora com sua inteligência a serviço da secretária da Educação, Esther Figueiredo Ferraz, no seu gabinete. Bárbara tem vários livros publicados, entre eles, Literatura e Gramática da Criança, e começa o ano 72 lançando seu livro de versos Apenas. (Bárbara..., 1972, n.p., destaques no original)

Durante o período em que atuou como assessora de Esther de Figueiredo Ferraz, Bárbara V. de Carvalho ministrou algumas palestras sobre literatura infantil. Em abril de 1973 foi convidada para proferir palestra sobre esse tema junto ao Conselho Municipal de Educação da cidade de Bauru (SP), a pedido do presidente desse Conselho, professor Aníbal Campi, e ministrou conferência sobre José Bento Monteiro Lobato na Biblioteca Infantil "Monteiro Lobato", ${ }^{3}$ em São Paulo-SP, em comemoração ao 37o Aniversário

3 Mediante atuação de Lenyra de Arruda Fraccaroli, em 14 de abril de 1936, foi fundada, em São Paulo (SP), a Biblioteca Infantil Municipal. A partir do ano de 1945, essa biblioteca foi transferida para um espaço maior, e, em 1950, passou a ser denominada Biblioteca Infantil "Monteiro Lobato", em homenagem ao escritor José Bento Monteiro Lobato. Essa biblioteca foi a primeira específica para o público infantil no estado de São Paulo e é a mais antiga biblioteca infantil em funcionamento no Brasil (Prefeitura de São Paulo, n.d.). 
da Divisão de Bibliotecas Infanto-juvenis e de Cinema Educativo da Secretaria de Educação e Cultura da Prefeitura de São Paulo. Ainda no ano de 1973, ministrou, como professora convidada, dois cursos de extensão universitária na Faculdade de Filosofia, Ciências e Letras de São Caetano do Sul, em São Caetano do Sul (SP).

Bárbara V. de Carvalho permaneceu como assessora da secretária de Educação do estado de São Paulo até 15 de dezembro de 1973, data em que se aposentou. Porém, mesmo aposentada, não interrompeu suas atividades ligadas à educação, sobretudo à literatura infantil.

No ano seguinte ao de sua aposentadoria, em 1974, ministrou aulas no curso "Atualização do Ensino em Língua Portuguesa", promovido pela Secretaria de Educação e Cultura do Estado da Bahia, e frequentou o curso "Semiologia", promovido pelo Departamento de Cultura da Secretaria de Cultura, Desportos e Turismo do estado da Guanabara.

Em 1975, foi convidada para ministrar aulas sobre literatura infantil para os alunos do 6을 semestre do curso de Biblioteconomia e Documentação da Escola de Comunicações e Artes (ECA) da Universidade de São Paulo (USP). E, ainda nesse mesmo ano, decidiu voltar a residir em Salvador, a partir de quando se intensificaram os convites para que ela ministrasse palestras e cursos sobre literatura infantil.

Depois de voltar a residir em Salvador, ainda no ano de 1975, o primeiro curso que Bárbara V. de Carvalho ministrou foi na cidade de Porto Alegre (RS), sobre literatura infantil, junto ao Departamento de Assuntos Culturais da Secretaria de Educação e Cultura do Rio Grande do Sul. Em 1976, foi convidada para ministrar conferência no Seminário de Literatura Infanto-Juvenil, realizado durante a Semana do Estudante do Instituto Central "Isaias Alves", em Salvador, e em 1978, retornou ao estado do Rio Grande do Sul, a convite da Secretaria de Educação e Cultura, para ministrar novo curso sobre literatura infantil para professores das delegacias de Educação de Porto Alegre, Pelotas e Caxias do Sul. Ainda no ano de 1978, Carvalho foi convidada para ministrar palestra sobre 
literatura infantil na Universidad de La Republica, em Montevidéu, Uruguai, e no ano seguinte, em 1979, ministrou a Conferência de Abertura do III Seminário de Literatura Infanto-Juvenil, em Vitória (ES).

Ao longo de sua atuação profissional, essa professora baiana participou como palestrante e conferencista de significativa quantidade de Congressos e Seminários brasileiros sobre literatura infantil, e, em decorrência de seu envolvimento com esse tema como estudiosa e escritora, na década de 1970, fez parte do grupo que fundou o Centro de Estudos de Literatura Infantil e Juvenil (Celiju), ${ }^{4}$ tendo sido a primeira presidente desse Centro, entre 1972 e 1974.

Além do Celiju, Carvalho também integrou duas outras importantes instituições relacionadas, respectivamente, à literatura infantil e à educação. Em 1978 foi eleita membro da Academia Brasileira de Literatura Infantil e Juvenil, tendo sido empossada em 1979, para ocupar a 29a cadeira, cuja patronesse era Denise Fernandes Tavares, sendo a única representante do estado da Bahia na Academia; em 1985 foi eleita membro titular da Academia Baiana de Educação, passando a ocupar a $12^{\mathrm{a}}$ cadeira, cujo patrono era Adroaldo Ribeiro Costa; e em 2001, por indicação de Leda Jesuíno dos Santos, recebeu o título de "Professor Emérito" dessa Academia.

Carvalho, depois de mais de sessenta anos de atuação no âmbito da educação brasileira e no estudo, ensino e divulgação da literatura infantil, faleceu, no dia 26 de julho de 2008, de insuficiência respiratória e doença de Parkinson, na cidade de Salvador. Nessa ocasião, Leda Jesuíno dos Santos (2008, p.92), presidente de honra da Academia Baiana de Educação e também amiga de Carvalho, proferiu discurso à beira do túmulo ressaltando que:

4 Criado no final da década de 1970, o Celiju teve como integrantes Lenyra Fraccaroli, Idaty Onagra, Maria Teresa Guimarães Noronha, Odette de Barros Mott, Esther Peixoto M. Gonçalves, Maria Lúcia P. Sampaio Góes, Cecília Mascarenhas, Lucília de Almeida Prado, Nelly Novaes Coelho, Noemia K. Pisani, Camila Cerqueira Cesar, Maria Lúcia Ramos, Eico Susuki, Lilian Malferrari e Giselda Laporte. Para informações detalhadas obre o Celiju, ver Oliveira (2014). 
[... ] neste domingo de inverno, [Carvalho] parte para outras dimensões ainda por nós desconhecidas, mas sempre e cada vez mais, consciente de que desempenhou o seu papel de mãe, esposa, mestra e amiga, com o maior empenho de ser e existir com autenticidade e grande capacidade de enfrentar corajosamente as dificuldades. Assim era Bárbara Carvalho, a dama da Literatura Infantil no Brasil. (destaques no original)

\section{A produção escrita de Bárbara V. de Carvalho}

Concomitantemente à sua atuação em cargos e funções no magistério e na divulgação da literatura infantil por meio de cursos e palestras, Bárbara V. de Carvalho contribuiu para a educação brasileira e para a literatura infantil por meio de sua produção escrita, que é representativa das ações pioneiras que desempenhou como divulgadora e estudiosa do gênero.

Ao longo de sua vida, escreveu artigos críticos sobre literatura brasileira e literatura infantil em periódicos e jornais de notícias, além de livros didáticos, contos, poesias, dicionários, livros de literatura infantil, livros sobre literatura infantil, e Compêndio de literatura infantil, o primeiro manual específico para o ensino da literatura infantil no Brasil.

Ao todo, pude reunir, até o momento, 74 referências da $1^{a}$ edição de textos escritos por Bárbara V. de Carvalho e outras 22 referências de diferentes edições de mesmos títulos entre as que localizei. A opção por localizar, recuperar e reunir as referências de diferentes edições de um mesmo título deve-se ao fato de que por meio delas é possível compreender as mudanças ocorridas, ou não, no processo de reedição desses títulos, como também entender quais livros tiveram maior circulação. Para proporcionar uma visão de conjunto e uma síntese dessas publicações, apresento no Quadro 5 a bibliografia de Carvalho, ordenada por tipo de texto e distribuída por ano de publicação, entre 1955 e 2004, considerando apenas a 1a edição de cada título. 
Quadro 5 - Bibliografia de Carvalho, por tipo de texto e década de publicação

\begin{tabular}{|c|c|c|c|c|c|c|c|c|}
\hline $\begin{array}{r}\text { Década de } \\
\text { publicação }\end{array}$ & $\begin{array}{c}1950 \\
-\end{array}$ & $\begin{array}{c}1960 \\
-\end{array}$ & $\begin{array}{c}1970 \\
-\end{array}$ & $\begin{array}{c}1980 \\
-\end{array}$ & $\begin{array}{c}1990 \\
-\end{array}$ & $\begin{array}{c}2000 \\
-\end{array}$ & s.d & $\begin{array}{c}\text { Total por } \\
\text { tipo de } \\
\text { texto }\end{array}$ \\
\hline Tipo de texto & 1959 & 1979 & 1989 & 1999 & 2009 & 1 \\
\hline Manual de ensino & 1 & - & - & - & - & - & - & 10 \\
\hline Livros didáticos & - & 2 & 8 & - & - & - & - & 2 \\
\hline $\begin{array}{c}\text { Livros sobre } \\
\text { literatura infantil }\end{array}$ & - & - & 1 & 1 & - & - & - & 14 \\
\hline $\begin{array}{c}\text { Livros de literatura } \\
\text { infantil }\end{array}$ & - & 2 & 4 & 7 & - & 1 & - & 14 \\
\hline Livros de poesias & 1 & - & 1 & - & - & - & - & 2 \\
\hline Livros adaptados & - & - & 3 & - & - & - & - & 3 \\
\hline Artigos em revistas & 2 & 4 & 3 & 2 & - & 1 & - & 12 \\
\hline Artigos em jornais & 4 & 2 & 4 & - & - & - & - & 10 \\
\hline $\begin{array}{c}\text { Entrevistas em } \\
\text { jornais }\end{array}$ & - & - & 5 & - & - & - & 1 & 6 \\
\hline $\begin{array}{c}\text { Poesias e conto em } \\
\text { revistas }\end{array}$ & - & - & - & 1 & - & 4 & - & $\mathbf{5}$ \\
\hline $\begin{array}{c}\text { Obras de } \\
\text { referência }\end{array}$ & - & - & 1 & 1 & - & - & - & 2 \\
\hline $\begin{array}{c}\text { Edições } \\
\text { estrangeiras }\end{array}$ & - & - & - & 4 & - & - & - & 4 \\
\hline Livros inéditos & - & - & - & - & - & - & 3 & 3 \\
\hline Total por década & 8 & 10 & 30 & 16 & - & 6 & 4 & - \\
\hline Total geral & & & & 74 & & \\
\hline
\end{tabular}

Fonte: Oliveira (2011a)

De acordo com as informações apresentadas no Quadro 5, Bárbara V. de Carvalho teve as primeiras edições de seus textos publicadas ao longo de 49 anos, entre 1955 e 2004. Embora eu tenha localizado informações de que durante a década de 1940 ela tenha escrito crônicas para a Rádio Sociedade de Salvador, ${ }^{5}$ não localizei

5 De acordo com informações contidas no site dessa rádio, ela foi fundada em 24 de março de 1924. Considerada a primeira emissora de rádio de Salvador (BA), a Rádio Sociedade também foi responsável pela criação do programa "Hora 
nenhuma dessas crônicas. Sendo assim, é possível afirmar que ela tenha iniciado sua produção escrita, pelo menos de modo sistematizado, a partir da década de 1950, quando passou a atuar como professora no estado de São Paulo.

Considerando o exposto, o primeiro texto que Carvalho teve publicado foi o livro de poesias para adultos Nuvens, pela editora Alarico (SP), em 1955. Após a publicação desse livro, no ano de 1956, ela teve publicados alguns artigos em jornais e revistas, nos quais apresenta ensaios críticos sobre romances da literatura brasileira. No ano de 1957, na ocasião em que participava da equipe responsável pela reformulação dos programas da disciplina Língua Portuguesa, teve publicado no jornal A gazeta, em São Paulo, o artigo "A literatura infantil na escola normal". Nesse artigo, Carvalho aborda alguns dos problemas relativos ao ensino da literatura infantil, em especial o da preocupação desnecessária dos professores relativamente à bibliografia disponível para esse ensino. Carvalho afirmava nesse artigo que, "[...] embora sejamos de uma lamentável pobreza no assunto, qualquer professor, de formação universitária, terá ao seu alcance livros em francês e espanhol, línguas incontestavelmente acessíveis ao professor de português" (Carvalho, 1957, p.19).

Após a publicação desse artigo, e apesar de afirmar que não era necessário os professores preocuparem-se com a escassez de bibliografia útil ao ensino da literatura infantil, Carvalho passou a ser recorrentemente convidada para explicar como é que se desenvolvia o ensino da literatura infantil (idem, 2010). Isso a levou a aprofundar seus estudos sobre o assunto e a escrever um manual de ensino de literatura infantil: Compêndio de literatura infantil: para o 3o ano normal, publicado em 1959 pela Companhia Editora Nacional.

da criança”, dirigido por Adroaldo Ribeiro Costa e direcionado ao público infantil no qual eram adaptadas histórias infantis em forma de opereta. Uma das histórias adaptadas por Adroaldo Ribeiro Costa para o programa "Hora da criança" foi Narizinho arrebitado, de José Bento Monteiro Lobato, que, na ocasião do lançamento dessa adaptação, em 1947, acompanhou a programação da Rádio Sociedade em Salvador (Rádio Sociedade, n.d.). 
Nesse manual, Carvalho apresenta uma concepção de literatura infantil que se relaciona à ideia de formação ética e estética da criança, que, por sua vez, está vinculada a um projeto maior de educação no qual a arte é um modo "atraente" de transmissão da cultura para as crianças que necessitam ser formadas. ${ }^{6}$

É importante destacar que, até a publicação de Compêndio de literatura infantil, haviam sido publicados, no Brasil, apenas capítulos sobre literatura infantil em manuais de ensino de língua e literatura (Oliveira, 2009). Esse manual foi o primeiro específico para o ensino da literatura infantil publicado no Brasil.

Após a publicação desse manual, durante a década de 1960, Carvalho iniciou sua atuação como escritora de livros destinados à leitura do público infantil, como é o caso de Cancioneiro da criança e Folclore e a criança, ambos publicados em 1961. Também a partir da década de 1960, ela iniciou sua atuação como autora de livros didáticos destinados aos alunos em fase inicial de escolarização, com a publicação, em 1969, de A gramática da criança: é uma graça, veja! e Literatura e gramática da criança: é uma graça, veja! (2o nível), e teve sua primeira obra de referência publicada, Dicionário de conjugação de verbos, também de 1969.

A partir da década de 1970, período em que atuou como assessora junto ao gabinete da secretária de Educação do estado de São Paulo, Carvalho teve aumento significativo em sua produção escrita, tendo tido publicados 28 livros somente nesse período. Dentre esses livros, destaco: as adaptações de contos estrangeiros, como $O$ gato de botas, $O$ barão de Munchausen e $O$ merlo; a coleção de livros didáticos É uma graça, veja!; uma coleção de antologias infantis; o livro de poesia para adultos Apenas...; um livro infantil publicado em formato de "quadros ilustrados", O saci e sua turma; os livros de literatura infantil A casinha nuvem e $O$ robozinho feio; além de artigos e entrevistas publicados em jornais e revistas de São Paulo, Porto Alegre, Salvador e Montevidéu (Uruguai).

6 Para informações mais detalhadas sobre Compêndio de literatura infantil, ver, especialmente: Oliveira (2010; 2013). 
Além da publicação desses textos, foi também durante a década de 1970, após quatorze anos da publicação de seu manual de ensino, que Carvalho teve publicado o seu primeiro livro sobre história e teoria da literatura infantil: Literatura infantil: estudos, publicado pela editora Lótus (SP) em 1973.

Embora Literatura infantil: estudos seja o primeiro livro de história e teoria da literatura infantil que Carvalho teve publicado, ele decorreu da reformulação e ampliação de Compêndio de literatura infantil, publicado em 1959. Porém, em Literatura infantil: estudos consta a informação de que se destina ao estudiosos e interessados na literatura infantil, como livro teórico.

Após ter tido publicada significativa quantidade de textos durante os anos de 1970, na década seguinte, entre 1980 e 1989, Carvalho teve pequena diminuição em sua produção escrita. Dentre os textos que ela teve publicado nesse período, destacam-se os livros de literatura infantil, que consistem em $50 \%$ de sua produção total relativamente a esse tipo de texto. Ao todo, Bárbara V. de Carvalho teve publicados quatorze livros de literatura infantil, e destes, sete durante a década de 1980, o que se deve ao fato de nesse período ela ter tido publicados os cinco livros que integram a coleção $\mathrm{Ca}$ lunga, da Companhia Melhoramentos (SP), cujos títulos são $A$ casinha da chaminé azul, Os dois gatos, Uma avenida na floresta, O papagaio Tubiba e A galinha contente; o livro O mãozinha, publicado pela Fundação Cultural do Livro (BA); e o livro Folclore, criança e fantasia, publicado pela Companhia Editora Nacional (SP) e que se trata de reformulação e ampliação do livro Folclore e a criança, publicado em 1961. Além desses, Carvalho teve alguns de seus livros, que integram a coleção Calunga, vertidos para o holandês e para o português de Portugal, para serem comercializados, respectivamente, na Holanda e em Portugal, também na década de 1980.

Ainda em relação às publicações de Carvalho durante a década de 1980, destaco a publicação do livro Literatura infantil: visão histórica e crítica, em 1982. 
Assim como ocorreu com a publicação de Literatura infantil: estudos, em 1973, que se originou da reformulação e ampliação de Compêndio de literatura infantil (1959), o livro A literatura infantil: visão história e crítica originou-se do livro Literatura infantil: estudos. Por esse motivo, o livro de 1982 teve sua publicação iniciada na $2^{a}$ edição, pois o livro de 1973 é considerado a 1ํe edição. Nesse sentido, por serem os livros Literatura infantil: estudos (1973) e A literatura infantil: visão histórica e crítica (1982) reformulações e ampliações direta ou indireta de Compêndio de literatura infantil, neles é possível identificar trechos idênticos aos contidos nesse manual de ensino, além de a concepção de literatura infantil expressa nesses dois livros ser igual à contida naquele manual (Oliveira, 2010).

Durante a década de 1990, Carvalho não teve nenhum texto publicado. Esse período coincide com o período em que ela passou a ter complicações de saúde, que culminaram no desenvolvimento da doença que ocasionou seu falecimento, em 2008. Apesar disso, em relação à década de 2000, pude localizar referências de textos de Bárbara V. de Carvalho, os quais haviam sido escritos antes do agravamento de sua doença, mas que só foram publicados posteriormente. Esse é o caso do livro de poesias infantis Bem-me-quer, publicado em 2003 e que consistiu em presente dado à Bárbara V. de Carvalho pelas amigas Consuelo da Silva Dantas, Eleusina Uzel, Leda Jesuíno dos Santos e Idati Onagra.

Apesar dessa diminuição da produção escrita de Carvalho a partir da década de 1990, é possível afirmar que seus textos continuaram a circular em decorrência das reedições que tiveram. Como informei, reuni 22 referências de diferentes edições de um mesmo título entre as que localizei, e, a fim de apresentar síntese dessas informações, apresento, no Quadro 6, a relação dos livros de Bárbara V. de Carvalho que tiveram mais de uma edição, o número das edições que localizei e as respectivas datas da $1 \underline{\underline{a}}$ edição e data da edição mais recente que localizei. 
Quadro 6 - Número das edições localizadas dos livros de Bárbara V. de Carvalho

\begin{tabular}{|c|c|c|c|}
\hline $\begin{array}{l}\text { Livros de Bárbara V. de } \\
\text { Carvalho }\end{array}$ & $\begin{array}{c}\text { Edições } \\
\text { localizadas }\end{array}$ & \begin{tabular}{|c|} 
Data da \\
$1^{\text {à }}$ edição
\end{tabular} & $\begin{array}{l}\text { Data da edição } \\
\text { mais recente }\end{array}$ \\
\hline Compêndio de literatura infantil & $1 \underline{a}, 2^{\mathrm{a}}, 3^{\mathrm{a}}$ & 1959 & s.d. \\
\hline $\begin{array}{l}\text { A literatura infantil: visão } \\
\text { histórica e crítica }\end{array}$ & $2^{\mathrm{a}}, 3^{\mathrm{a}}, 4^{\mathrm{a}}, 6^{\mathrm{a}}$ & 1982 & 1989 \\
\hline O papagaio Tubiba & $1 \underline{\mathrm{a}}, 2^{\mathrm{a}}, 4 \mathrm{a}, 5^{\mathrm{a}}, 8^{\mathrm{a}}$ & 1980 & 1988 \\
\hline A galinha contente & $1^{\mathrm{a}}, 2^{2}, 3^{\mathrm{a}}, 4^{\mathrm{a}}, 6^{\mathrm{a}}, 8^{\underline{\mathrm{a}}}$ & 1980 & 1990 \\
\hline Uma avenida na floresta & 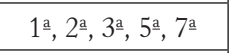 & 1980 & 1991 \\
\hline Os dois gatos & $1 \underline{a}, 2^{a}, 6^{\underline{a}}$ & 1980 & s.d \\
\hline $\begin{array}{c}\text { Pequeno dicionário de regência } \\
\text { verbal }\end{array}$ & $1^{\mathrm{a}}, 2^{\mathrm{a}}$ & 1971 & 1986 \\
\hline $\begin{array}{c}\text { Dicionário de conjugação de } \\
\text { verbos }\end{array}$ & $1^{\mathrm{a}}, 3^{\mathrm{a}}$ & 1969 & 1975 \\
\hline
\end{tabular}

Fonte: Oliveira (2011a)

Por meio das informações apresentadas no Quadro 6, é possível compreender que os livros de literatura infantil de Bárbara V. de Carvalho foram os que tiveram maior número de edições. Apesar de esses livros integrarem todos uma mesma coleção - Calunga -, é possível observar, de acordo com as informações apresentadas no Quadro 6, que ele não tiveram suas reedições publicadas sempre no mesmo ano, pois a 8a edição de O papagaio Tubiba é de 1988, e o exemplar da 7a edição de Uma avenida na floresta é de 1991.

De acordo com as informações apresentadas no Quadro 5, Carvalho não teve publicado nenhum título novo durante a década de 1990, porém, de acordo com as informações apresentadas no Quadro 6, durante essa década ela teve publicadas reedições de Uma avenida na floresta e A galinha contente, livros de literatura infantil que integram a coleção Calunga.

\section{A produção escrita sobre Bárbara V. de Carvalho}

Na medida em que a produção escrita de Bárbara V. de Carvalho passou a circular e ser utilizada por professores, professorandos, 
autores de textos sobre literatura infantil e até pelas crianças, aspectos da vida dessa autora, sua formação e atuação profissional passaram a ser mencionados em textos de outros autores, além de seus textos também terem-se tornado objeto de citação.

Considerando isso, além dos textos de Bárbara V. de Carvalho, também reuni 107 referências de textos sobre ela, dentre os quais 21 são referências de textos que tratam especificamente de aspectos de sua vida, formação, atuação profissional e produção escrita, e as demais, 86, são de textos que contêm menção a ela, sua formação, atuação profissional e produção escrita e/ou citam seus textos.

Para propiciar uma visão de conjunto e síntese das publicações sobre Carvalho, apresento, no Quadro 7, os tipos de textos escritos sobre essa autora, distribuídos por década de publicação, entre 1959 e 2011.

Os textos sobre Bárbara V. de Carvalho e os textos com menções a sua atuação profissional ou produção escrita e/ou que contêm citações de seus textos foram publicados entre 1959 e 2011. Entretanto, nesse período há alguns anos em que não houve publicação de textos sobre essa professora. Também é possível observar que a partir de 1999 tornaram-se regulares as publicações de textos sobre Bárbara V. de Carvalho.

De acordo com o Quadro 7, os textos mais antigos que tratam especificamente de Bárbara V. de Carvalho são: artigo publicado no jornal A tarde, presumivelmente de Salvador (BA), de autoria de Consuelo da Silva Dantas, e prefácio escrito por Adroaldo Ribeiro Costa, publicado no livro O mãozinha (1980).

Das 21 referências de textos que tratam especificamente da vida e atuação profissional de Carvalho, é possível afirmar que apenas onze tratam, ${ }^{7}$ do ponto de vista acadêmico-científico, de aspectos sobre essa professora, em especial de sua produção escrita. Os demais textos foram escritos com finalidades de apresentar ou prefaciar livros de autoria dela, homenageá-la e divulgar seus livros na ocasião do lançamento.

7 Desses textos, nove são de minha autoria, e neles apresento resultados parciais e finais da pesquisa de mestrado (Oliveira, 2010). 
Quadro 7 - Bibliografia sobre Carvalho, por tipo de texto e década de publicação

\begin{tabular}{|c|c|c|c|c|c|c|c|c|}
\hline Tipo de texto $\begin{array}{r}\text { Década de } \\
\text { publicação }\end{array}$ & $\begin{array}{c}1950 \\
- \\
1959\end{array}$ & $\begin{array}{c}1960 \\
- \\
1969\end{array}$ & $\begin{array}{c}1970 \\
- \\
1979\end{array}$ & $\begin{array}{c}1980 \\
- \\
1989\end{array}$ & $\begin{array}{c}1990 \\
- \\
1999\end{array}$ & $\begin{array}{c}2000 \\
- \\
2009\end{array}$ & s.d & $\begin{array}{l}\text { Total por } \\
\text { tipo de } \\
\text { texto }\end{array}$ \\
\hline Textos acadêmicos & - & - & - & 1 & - & 5 & - & 6 \\
\hline $\begin{array}{l}\text { Artigos e notas em } \\
\text { jornais e revistas }\end{array}$ & - & 1 & 3 & 2 & 1 & 1 & - & 8 \\
\hline $\begin{array}{c}\text { Prefácio e/ou } \\
\text { apresentação em } \\
\text { livros }\end{array}$ & - & - & - & 2 & - & 1 & - & 3 \\
\hline $\begin{array}{c}\text { Verbete em } \\
\text { dicionário }\end{array}$ & - & - & - & 1 & - & - & - & 1 \\
\hline $\begin{array}{c}\text { Entrevista sobre } \\
\text { Bárbara V. de } \\
\text { Carvalho }\end{array}$ & - & - & - & - & - & 2 & - & 2 \\
\hline $\begin{array}{c}\text { Homenagem } \\
\text { póstuma }\end{array}$ & - & - & - & - & - & 1 & - & 1 \\
\hline $\begin{array}{c}\text { Menção e/ou citação } \\
\text { em manuais de } \\
\text { ensino }\end{array}$ & - & 2 & 2 & 3 & - & - & 1 & 8 \\
\hline $\begin{array}{c}\text { Menção e/ou citação } \\
\text { em livros }\end{array}$ & - & 2 & 1 & 4 & 1 & 4 & - & 12 \\
\hline $\begin{array}{c}\text { Menção e/ou citação } \\
\text { em capítulos de } \\
\text { livros }\end{array}$ & - & - & - & - & - & 3 & - & 3 \\
\hline $\begin{array}{c}\text { Menção e/ou citação } \\
\text { em bibliografia } \\
\text { sobre literatura } \\
\text { infantil }\end{array}$ & - & - & 2 & 1 & - & - & - & 3 \\
\hline $\begin{array}{c}\text { Menção e/ou } \\
\text { citação em artigo em } \\
\text { periódico }\end{array}$ & - & 1 & - & 2 & - & 8 & - & 11 \\
\hline $\begin{array}{l}\text { Menção e/ou } \\
\text { citação em textos } \\
\text { acadêmicos }\end{array}$ & - & - & - & - & - & 26 & 1 & 27 \\
\hline $\begin{array}{c}\text { Menção e/ou citação } \\
\text { em artigo e notas em } \\
\text { jornais }\end{array}$ & 1 & 3 & 9 & 4 & - & - & 4 & 21 \\
\hline $\begin{array}{c}\text { Menção e/ou citação } \\
\text { em documento } \\
\text { oficial }\end{array}$ & - & - & - & 1 & - & - & - & 1 \\
\hline Total por década & 1 & 9 & 17 & 21 & 2 & 48 & 7 & - \\
\hline Total geral & \multicolumn{8}{|c|}{107} \\
\hline
\end{tabular}

Fonte: Fonte: Oliveira (2011a) 
No conjunto das publicações de textos que tratam especificamente de Carvalho, destaco: artigo de Dormevilly Nóbrega, publicado em 1961, no jornal Diário Mercantil, de Juiz de Fora (MG), no qual a autora faz comentários elogiosos a respeito da publicação da 2ª edição de Compêndio de literatura infantil; o artigo "Pioneirismo em educação”, publicado em 1970 no jornal Folha de S. Paulo, de São Paulo (SP), no qual consta a informação de que "[...] Bárbara de Vasconcelos é uma das intelectuais brasileiras de que se orgulha nosso corpo docente, sobretudo pelo pioneirismo com que tem aberto novos ramos ao ensino em nosso país" (Pioneirismo..., 1970, n.p.); o artigo de Antônio D’Ávila, "Bárbara Vasconcelos de Carvalho: a literatura infantil”, publicado no jornal O Anchieta, de São Paulo, em 1983, no qual o autor afirma que Carvalho “[...] sem dúvida [...] foi pioneira no assunto [do ensino da literatura infantil] e o fez com grande brilho, graças à sua cultura linguística e seus conhecimentos da matéria." (D’Ávila, 1983, p.3); a publicização, em 1983, da dissertação de mestrado $O$ discurso especializado em literatura infanto-juvenil no Brasil na década de 50: da criança mitificada à atitude política, na qual Mello Neto (1983) aborda os textos sobre literatura infantil publicados entre 1950 e 1959, entre os quais Compêndio de literatura infantil; e a publicação do verbete sobre essa professora baiana contido no Dicionário crítico da literatura infantil/juvenil brasileira (1882-1982), de Coelho (1983).

No caso dos textos que contêm apenas menções a Carvalho, sua vida, formação, atuação profissional e produção escrita e/ou citam seus textos, a grande maioria dessas referências (27) é relativa a textos acadêmicos (teses, dissertações, TCCs e textos em anais de eventos) publicados entre 2001 e 2011 e nos quais há citações retiradas de trechos de livros de autoria de Carvalho. Por meio da análise das referências desses textos acadêmicos, pude observar que grande parte deles (23) foi publicada nas regiões Sudeste e Sul do Brasil, e apenas quatros desses textos foram publicados em outras regiões do Brasil: um na Região Nordeste e três na Região Centro-Oeste. Presumo que, pelo fato de essa professora ter atuado principalmente nos estados de São Paulo e Rio Grande do Sul, tenha havido maior circulação de seus textos nas regiões Sul e Sudeste. 
Ao analisar as referências desses textos acadêmicos, pude observar que neles a literatura infantil é abordada com finalidades diferentes, pois há textos em que são apresentadas análises de livros de literatura infantil (do ponto de vista da crítica literária) e há textos em que o livro de literatura infantil é mencionado como recurso para mediar atendimento odontológico.

Seguido dos textos acadêmicos, o tipo de texto que mais localizei que contém menções a Carvalho e/ou citações de seus textos foram artigos e notas em jornais - 21 referências. Publicados entre 1959 e 1986, neles há menções aos cursos ministrados por Carvalho, a sua participação em bienais do livro, sobre lançamento de livros de sua autoria e sobre suas ações pioneiras no ensino da literatura infantil.

Além dos textos acadêmicos e dos artigos e notas em jornais, destaco as menções a Carvalho e citações de seus textos em livros como Literatura infantil brasileira: ensaio de preliminares para a sua história e suas fontes, de Arroyo (1968), e A literatura infantil: história, teoria, análise, de Coelho (1981).

Como Carvalho é autora do primeiro manual de ensino de literatura infantil, outros autores de manuais de ensino e/ou capítulos utilizaram o manual dessa professora baiana como base para formular os seus. De acordo com as informações apresentadas no Quadro 7, oito manuais de ensino contêm citações de textos de Carvalho. Desse número, cinco são destinados ao ensino da literatura infantil e dois contêm capítulos sobre literatura infantil.

Também algumas bibliografias sobre literatura infantil contêm menções à produção escrita de Bárbara V. de Carvalho. Segundo Magnani (1998), a partir da década de 1960, com uma produção mais sistemática de livros de literatura infantil, passaram a ser publicadas bibliografias especializadas sobre literatura infantil, nas quais estão reunidos títulos de livros de literatura infantil publicados no Brasil. Entre as bibliografias publicadas no Brasil, três contêm menções aos livros de literatura infantil de Carvalho.

Além desses textos sobre Bárbara V. de Carvalho, é importante destacar que Compêndio de literatura infantil (1959) é indicado como bibliografia básica sobre literatura infantil e recomendado 
como adequado para o desenvolvimento da disciplina "Literatura Infantil" no documento oficial Habilitação específica de 2 Grau para o magistério: guias curriculares para a parte diversificada da formação especial, elaborado pela Coordenadoria de Estudos e Normas Pedagógicas do estado de São Paulo (CENP) e publicado em 1981. Esse documento teve a finalidade de subsidiar a elaboração de planos de ensino dos diferentes componentes curriculares do curso de Habilitação Específica para o Magistério (HEM) do estado de São Paulo.

Ao analisar, de modo geral, as 87 referências de textos que contêm menções a Carvalho, sua atuação profissional ou produção escrita e/ou citam seus textos, pude observar que o livro mais recorrentemente citado e/ou mencionado é Literatura infantil: visão histórica e crítica, em suas diferentes edições, seguido de Compêndio de literatura infantil, também em suas diferentes edições. Esse aspecto permite afirmar que o reconhecimento de sua atuação profissional decorreu, sobretudo, de seu pioneirismo em ter tido publicado um manual de ensino de literatura infantil e de sua dedicação no estudo, ensino e divulgação desse gênero literário.

\section{O pioneirismo de Bárbara Vasconcelos de Carvalho}

Nascida no estado da Bahia, no início do século XX, e tendo-se formado professora no momento histórico de disseminação das ideias "renovadoras" em Educação, Bárbara V. de Carvalho, ainda que pertencesse a um núcleo familiar de condições financeiras limitadas, integrou uma parte da população brasileira extremamente privilegiada, sobretudo no início do século XX, quando poucos podiam frequentar a escola primária, os cursos normais e os cursos de licenciatura.

Nesse sentido, é possível compreender que, ao longo de sua infância e juventude, Bárbara V. de Carvalho tenha vivenciado condições de vida pouco comuns à maior parte da população brasileira da época, o que lhe proporcionou uma formação cultural também 
bastante diferenciada, sobretudo ao cursar a escola normal e a graduação em Letras Neolatinas, a partir de quando teve seus primeiros contatos teóricos e práticos com questões como teoria literária, especificidade do ensino de língua e literatura e o estudo de línguas estrangeiras (francês e espanhol), que lhe possibilitou conhecer e ler livros sobre literatura infantil em outras línguas, utilizando-os como referencial teórico dos textos que teve publicados.

Toda essa formação diferenciada, as relações que passou a estabelecer como professora tanto em Salvador (BA) quanto em São Paulo (SP) e as influências que recebeu com o convívio e leitura de textos de outros autores concorreram na sua formulação de uma concepção de literatura, que teve seus desdobramentos na concepção de literatura infantil e de ensino da literatura infantil, apresentada inicialmente em Compêndio de literatura infantil.

A partir dessa concepção de ensino de literatura infantil que formulou, Carvalho passou a escrever livros de literatura infantil, fazendo com que lhe fosse conferido, além do status de estudiosa da literatura infantil, o status de escritora e poetisa, o que penso ter impulsionado sua participação em grupos importantes na história da literatura infantil brasileira e no seu respectivo campo de conhecimento, como é o caso do Celiju e da Academia Brasileira de Literatura Infantil e Juvenil.

Pelo exposto, e também considerando os cargos e as funções que Carvalho ocupou em diferentes órgãos vinculados à Secretaria de Educação do estado de São Paulo, essa professora ocupa lugar de destaque em relação às influências que exerceu na formação de diferentes gerações de professores e de estudiosos da literatura infantil. Conforme ministrava seus cursos sobre literatura infantil para professores e professorandos, em diferentes localidades do Brasil, e à medida que seus livros e artigos foram sendo lidos e utilizados, ela contribuiu para disseminar uma concepção de literatura infantil, característica das urgências e necessidades educacionais de sua época, a qual ainda se faz presente nos dias atuais nas discussões sobre literatura infantil, mesmo que de forma não hegemônica. 
Também seus livros didáticos e seus livros de literatura infantil exerceram certa influência em diferentes gerações de crianças, que, em fase de escolarização, tiveram contato com esses textos e os utilizaram como fonte de leitura e estudo.

Sendo assim, considero que o lugar que Carvalho ocupa na história do ensino da literatura infantil é o de pioneira nesse ensino, seja pelas "tematizações" que fez por meio de palestras, conferências e cursos que ministrou, seja por sua participação na equipe que reformulou o programa de língua portuguesa e a partir do qual literatura infantil foi instituída como disciplina, seja, ainda, pela "concretização" de sua proposta para o ensino da literatura infantil contida em Compêndio de literatura infantil, que se tornou base para os demais autores de manuais de ensino e contribuiu para a sistematização de um corpo de conhecimento relativo ao ensino da literatura infantil, considerado necessário à formação do professor primário, no terceiro momento história da alfabetização no Brasil.

Além disso, compreendo que, embora o lugar de onde Carvalho "fala" não seja o mesmo dos autores dos principais livros teóricos sobre literatura infantil publicados no Brasil, é possível afirmar que seu pensamento sobre literatura infantil também ocupa lugar importante nessa produção, pois seus livros sobre história, teoria e crítica da literatura infantil, decorrentes de reformulações de Compêndio de literatura infantil, são bastante citados e utilizados por pesquisadores da área.

Por fim, penso serem inestimáveis as contribuições dessa professora baiana no âmbito do ensino da literatura infantil, no Brasil, e negar seu pioneirismo e sua contribuição é negar também uma das várias facetas que constituem a complexidade do fenômeno "literatura infantil" nesse país.

\section{Referências bibliográficas}

ARROYO, L. Literatura infantil brasileira - ensaio de preliminares para a sua história e suas fontes. São Paulo: Melhoramentos, 1968. 
CARVALHO, B. V. A literatura infantil na Escola Normal. Gazeta de São Paulo, São Paulo, 1957.

. Compêndio da literatura infantil: para o $3^{\circ}$ ano normal. São Paulo: Companhia Editora Nacional, 1959.

CARVALHO, C. V. de. Entrevista. Salvador, 2010 (digitado).

CECCANTINI, J. L. C. T. Perspectivas de pesquisa em literatura infanto-juvenil. In: (org.). Leitura e literatura infanto-juvenil: memória de Gramado. São Paulo: Cultura Acadêmica, 2004.

COELHO, N. N. Dicionário crítico da literatura infantil e juvenil brasileira. São Paulo: Quíron, 1983.

Dicionário crítico da literatura infantil e juvenil brasileira. 5.ed. São Paulo: Companhia Editora Nacional, 2006.

. A literatura infantil: história - teoria - análise. São Paulo: Quíron, 1981

D'ÁVILA, A. Bárbara Vasconcelos de Carvalho: a literatura infantil. $O$ Anchieta, São Paulo, p.3, maio-jul. 1983.

BELLOTTO, H. L. Os instrumentos de pesquisa no processo historiográfico. In: Congresso Brasileiro de Arquivologia, 4, 1979, Anais..., p.133-47.

LAJOLO, M.; ZILBERMAN, R. Literatura infantil brasileira: história \& histórias. 6.ed. São Paulo: Ática, 2005.

LOURENÇO FILHO, M. B. Como aperfeiçoar a literatura infantil. Revista Brasileira. Rio de Janeiro, v.3, n.7, p.146-69,1943.

MAGNANI, M. do R. M. Entre a literatura e o ensino: um balanço das tematizações brasileiras (e assisenses) sobre literatura infantil e juvenil. Miscelânea, Assis, v.3, p.247-57, 1998.

Os sentidos da alfabetização: a "questão dos métodos" e a constituição de um objeto de estudo (São Paulo/1876-1994). Presidente Prudente, 1997. 389f. Tese (Livre-Docência em Metodologia do Ensino de 1ํGrau: Alfabetização) - Faculdade de Ciências e Tecnologia, Universidade Estadual Paulista.

Os sentidos da alfabetização: São Paulo 1876/1994. São Paulo: Editora Unesp, 2000.

MARINHO, M. Atesto... Salvador, 24 jan. 1949. Documento manuscrito. MEIRELES, C. Problemas da literatura infantil. Belo Horizonte: Secretaria de Educação, 1952.

MELLO NETO, G. A. R. O discurso especializado em literatura infanto-juvenil no Brasil na década de 50: da criança mitificada à atitude política. São Paulo, 1988. 310f. Dissertação (Mestrado em Psicologia Social) - Pontifícia Universidade Católica. 
MORTATTI, M. do R. L. Leitura crítica da literatura infantil. Leitura: teoria \& prática, Campinas: ALB, ano 19, n.36, p.11-7, dez. 2000.

NÓBREGA, Dormevilly. Literatura infantil. Diário Mercantil, Juiz de Fora, 22 ago. 1961.

OLIVEIRA, F. R. de. Manuais de ensino de literatura infantil (1923-1991): autores, produção e circulação. Marília, 2009. 101f. Trabalho de Conclusão de Curso (Graduação em Pedagogia) - Faculdade de Filosofia e Ciências, Universidade Estadual Paulista.

O ensino da literatura infantil em Compêndio de literatura infantil: para o 3o ano normal (1959), de Bárbara Vasconcelos de Carvalho. Marília, 2010. 247f. Dissertação (Mestrado em Educação) - Faculdade de Filosofia e Ciências, Universidade Estadual Paulista.

. Bibliografia de e sobre Bárbara Vasconcelos de Carvalho: um instrumento de pesquisa. Marília, 2011a. (digitado).

. Bárbara Vasconcelos de Carvalho e o ensino da literatura infantil no Brasil. São Paulo: Editora Unesp, 2013.

História do ensino da literatura infantil nos cursos de formação de professores primários no estado de São Paulo, Brasil (1947-2003). Marília, 2014. 344f. Tese (Doutorado em Educação) - Faculdade de Filosofia e Ciências, Universidade Estadual Paulista.

Considerações sobre a história do ensino da literatura infantil nos Cursos Normais no Brasil: o pioneirismo de Bárbara Vasconcelos de Carvalho. História da Educação, Pelotas, v.15, n.34, p.123-40, maio-ago. 2011b.

PIONEIRISMO em Educação. Folha de S. Paulo. São Paulo, [s.p.], 18 jan. 1970.

SANTOS, L. J. Discurso na concessão do título de acadêmico emérito à professora Bárbara V. de Carvalho. Revista da Academia Baiana de Educação, v.2, n.7, p.7-48, set. 2001. Entrevista. Salvador, 2010. (digitado).

SÃO PAULO (Estado). Habilitação específica de 2º Grau para o magistério: guias curriculares para a parte diversificada da formação especial. São Paulo: Cenp, 1981. 


\section{3 \\ Emilia FerReiro (1935-) \\ E A PSICOGÊNESE DA LÍNGUA ESCRITA ${ }^{1}$}

Márcia Cristina de Oliveira Mello

\section{Introdução}

Este texto tem como objetivo apresentar aspectos da vida, da obra e do pensamento de Emilia Ferreiro (1935-) sobre alfabetização. Sendo reconhecida internacionalmente por suas contribuições à compreensão do processo evolutivo de aquisição da linguagem escrita nas crianças, o pensamento construtivista de Ferreiro é representativo de um importante momento da história recente da alfabetização no Brasil. Trata-se, como apontam Magnani (1997) e Mortatti (2000; 2007), do "quarto momento" (ainda em curso) da história da alfabetização no Brasil, em que se destaca a "revolução conceitual", proposta por Ferreiro e de que resulta a hegemonia do chamado construtivismo em alfabetização, em oposição à "tradicional" discussão sobre métodos de alfabetização.

Segundo Magnani (1997) e Mortatti (2000), o início da inserção do pensamento da psicóloga argentina no Brasil deu-se no início

1 Este texto é resultante de pesquisa de mestrado, desenvolvida com bolsa Capes, cujos resultados finais foram apresentados sob a forma de dissertação de mestrado (Mello, 2003). Com adequações de redação, a dissertação foi publicada em livro (Mello, 2007) [N. O.]. 
dos anos de 1980, relacionado à divulgação de resultados de pesquisas contidos especialmente no livro Psicogênese da língua escrita, em que não se encontra uma proposta didática de alfabetização, nem "receitas prontas" com intenção de garantir o sucesso da alfabetização de todas as crianças em fase inicial de escolarização. O que se tem é uma "revolução conceitual" em alfabetização.

Na primeira parte deste texto, apresento os aspectos relacionados à vida, formação e atuação profissional de Emilia Ferreiro. $\mathrm{Na}$ segunda parte encontra-se a bibliografia disponível de Ferreiro. Por fim, tem-se a bibliografia sobre seu pensamento construtivista sobre alfabetização. A apresentação e problematização desses dados têm como objetivo contribuir para a compreensão desse passado recente e ainda presente, por meio da compreensão do contexto de surgimento, produção e divulgação de uma teoria sobre alfabetização: a psicogênese da língua escrita, de acordo com Emilia Ferreiro.

\section{De estudante de Psicologia a pesquisadora reconhecida ${ }^{2}$}

Emilia Ferreiro nasceu na Argentina, em 1937, licenciou-se em Psicologia na Universidade de Buenos Aires no ano de 1962 e, segundo a pesquisadora, pertence à "primeira geração de psicólogos argentinos". Foi também delegada estudantil no Conselho Diretor da Universidade de Buenos Aires, à época em que se enfatizava, nessa mesma universidade, a Psicanálise, com destaque para as contribuições de Sigmund Freud e Melaine Klein. De tudo o que aprendia, desagradava Ferreiro o fato de se aplicarem testes, principalmente o de "Escala Wechsler de Inteligência para Crianças"

2 Para a elaboração desta subseção, baseei-me em informações contidas no Curriculum vitae de Emilia Ferreiro, encaminhado por e-mail pela pesquisadora (Ferreiro, 2001b; 2001c). Tais informações encontravam-se em espanhol e foram traduzidas livremente por mim. Além dessas informações, utilizei outras contidas em Teberosky (1985), Ferreiro (2001a) e Mortatti (2000). 
(WISC - Wechsler intelligence scale for children) $)^{3}$ e contar quantas respostas erradas as crianças davam.

Foi a leitura do livro Psicologia da inteligência, de Jean Piaget, que despertou o interesse de Ferreiro pelas ideias do pesquisador suíço, nas quais ela encontrou o enfoque que lhe agradava. Começou então a estudar a Psicologia da inteligência e fez leituras de outros livros do pesquisador, mas não tinha com quem discutir suas interpretações.

Nos anos de 1960, foi para a cidade de Genebra-Suíça, onde, já com algum conhecimento da teoria de Piaget, tentou aproximar-se do mestre, mas "[...] não queria estudar as clássicas classificações, seriações e conservações” (Ferreiro, 2001a, p.57). Ela queria verificar se realmente a teoria de Piaget era uma teoria geral de processos de aquisição de conhecimento.

Ainda na década de 1960, foi trabalhar como auxiliar de pesquisa, com Hermine Sinclair, que "[...] tinha o primeiro grupo que realmente se dedicou à análise da linguagem na Universidade de Genebra" (ibidem, p.59). Trabalhou também com Bärbel Inhelder e lecionou Psicanálise, mas ainda não estava próxima de Piaget. Com esse objetivo, solicitou ingresso no Centro Internacional de Epistemologia Genética, ${ }^{4}$ situado em Genebra e dirigido por Jean Piaget, que, naquela época, costumava dar uma oportunidade a quem a solicitava: "Geralmente, ele designava um problema e dizia

3 Segundo Harris e Hodges (1999, p.99), trata-se de “[...] qualquer um dos vários testes de capacidade mental geral administrados individualmente e desenvolvidos por Wechsler para apontar os QIs verbal e não-verbal separadamente, assim como o QI total".

4 O Centro Internacional de Epistemologia Genética foi fundado em 1955, por Jean Piaget. Trata-se da concretização de um projeto do pesquisador suíço de criar uma disciplina, a "Epistemologia Genética", que procurava desvendar, por meio da experimentação, os processos fundamentais de formação do conhecimento na criança. Para tanto, Piaget reuniu pesquisadores de diferentes partes do mundo que pesquisavam sobre diversos assuntos. Essa disciplina preocupava-se em descobrir as raízes das diversas variedades de conhecimento, desde suas formas mais elementares até sua evolução ao pensamento científico. A esse respeito, ver Piaget (1978). 
'desenvolvam'-no, e isso queria dizer encontrar a técnica, levantar os dados e fazer um relatório” (ibidem, p.59). Em suas férias, Piaget analisava o relatório e dava o parecer.

O tema proposto a Ferreiro foi "Movimento browniano", que envolvia noções e relações físicas elementares e, para a pesquisadora, era de difícil desenvolvimento. Mas ela contou com a sorte: seu marido, Rolando Garcia, era físico e ajudou-a a encontrar uma solução para estudar o "Movimento browniano" com crianças pequenas. Mais tarde, Rolando Garcia também ingressou no Centro Internacional de Epistemologia Genética, já que Piaget estava procurando físicos com interesse epistemológico.

Ferreiro levantou os dados, analisou-os e entregou o relatório a Piaget, que lhe deu uma resposta favorável, passou a ter confiança em seu trabalho e começou a requisitar sua presença no Centro Internacional de Epistemologia Genética. Ferreiro também começou a desenvolver, com Sinclair, uma pesquisa sobre a aquisição da linguagem. Somente depois de um ano é que propuseram a ela desenvolver uma pesquisa em nível de doutorado, já que Piaget tinha interesse no tema e Ferreiro conhecia a "revolução" que Noam Chomsky ${ }^{5}$ estava fazendo no campo da Linguística.

Como, no momento, estavam sendo retomados os estudos sobre a linguagem, que, segundo Ferreiro, tinham sido deixados de lado por algum tempo, e, naquele momento, a Psicolinguística ${ }^{6}$ con-

5 O linguista norte-americano Avram Noam Chomsky nasceu na Filadélfia, Pensilvânia, no ano de 1928. Frequentou a Universidade de Pensilvânia e estudou Linguística nessa universidade, local em que se doutorou no ano de 1957. Como resultado de seus estudos, realizou importantes renovações teóricas relacionadas aos domínios da Linguística, combatendo as tendências behaviorista e estruturalista. Formulou sua "Gramática" fundamentada no pressuposto de que os indivíduos são dotados de uma capacidade inata de aprender a língua, assim, todos os indivíduos adquirem gramáticas próximas em tempo consideravelmente curto. A esse respeito, ver Lyons (1976).

6 Segundo Cabral e Nick (1998, p.245), a Psicolinguística é "O estudo da comunicação humana através da linguagem. A linguagem é parte integrante do comportamento humano, quer como indivíduos ou como membros de um grupo social, não podendo, portanto, deixar de atrair o interesse dos psicó- 
temporânea estava sendo construída, Ferreiro estudou "as relações temporais". Enfrentou dificuldades a princípio, porque "[...] ao contrário do que se pensa, em Genebra ninguém ensina você a usar o método clínico" (ibidem, p.59). ${ }^{7}$ Seu francês também não era muito bom, e ela tinha que entrevistar crianças em situação experimental, além de dar aulas de Psicanálise. Sem bolsa de estudos, tinha de trabalhar ao mesmo tempo em que desenvolvia os estudos e as pesquisas para sua tese. Até o fim desta, trabalhou como assistente do Centro Internacional de Epistemologia Genética, lidando com temas como transmissão de movimentos, que não se vinculavam com sua formação.

Em 1970, Ferreiro doutorou-se em Psicologia, pela Universidade de Genebra, sob a orientação de Jean Piaget, que também escreveu o prefácio do livro que resultou da tese da pesquisadora: Les relations temporelles dans le langage de I'enfant (1971).

Após ter terminado o doutorado e ter voltado a Buenos Aires, no ano de 1970, Ferreiro, que já se interessava pelo uso da linguagem oral, começou a "[...] trabalhar com a língua escrita como uma espécie de passagem inevitável pela escrita para voltar à língua oral” (ibidem, p.17).

Tinha trabalhado sobre problemas de aquisição da língua oral e estava interessadíssima em continuar investigando sobre isso [...], eu já tinha voltado com um tema, coisa que ocorre com frequência depois de uma tese: ao resolver um problema, descobrem-se outros

logos". Ainda segundo esses autores, "Três influências principais se conjugaram na criação da Psicolinguística: a teoria da informação, a psicologia da aprendizagem e retenção e a linguística contemporânea", esta última representada também por Noam Chomsky. Emilia Ferreiro e Ana Teberosky utilizam o termo "Psicolinguística contemporânea" relacionado com a fase "pós-chomskyana".

7 Segundo Harris e Hodges (1999, p.182), método clínico é "[...] nos trabalhos de Piaget, um procedimento de entrevista para investigar os processos cognitivos das crianças. Em seus trabalhos posteriores, uma combinação de entrevista e de experimento, chamada de investigação crítica”. 
ao mesmo tempo. Eu tinha trabalhado o problema da expressão das relações de tempo na linguagem, as relações de sucessão e a simultaneidade. No decorrer da pesquisa, descobri que as orações subordinadas com pronomes relativos estabeleciam um problema de compreensão bastante sério para as crianças. Queria estudar isso. (ibidem, p.16)

O trabalho com a língua escrita tornou-se tão interessante, que Ferreiro precisou de auxiliares para as investigações. Como era a única latino-americana com doutorado orientado por Jean Piaget, muitos eram os interessados.

$\mathrm{Na}$ medida em que desenvolvia as investigações, a quantidade de perguntas ia aumentando, o que tornou necessário um estudo mais detalhado sobre o tema. Ferreiro afirma que sem sua formação piagetiana nada teria descoberto: "Houve momentos muito particulares, muito intensos, nos quais minha formação prévia foi fundamental; sem ela, não teria visto nada" (ibidem, p.30).

Sobre a relação entre a tese de doutorado e os estudos realizados posteriormente, que resultaram na teoria sobre a psicogênese da língua escrita, Ferreiro afirma que há uma continuidade em relação àqueles estudos, no sentido de que a escrita também é um objeto linguístico, mas admite certa descontinuidade em relação a eles, na medida em que as perguntas fundamentais passaram a ser diferentes.

[...] há continuidade porque, dentro do funcionamento simbólico, continuam interessando-me os sistemas simbólicos socialmente constituídos. Mas a pergunta mudou, porque eu não tinha uma pergunta epistemológica muito clara em minha tese, e esta indagação sobre a escrita tem uma veia epistemológica muito mais clara - as perguntas constantes têm sido: que tipo de objeto é esse objeto para a criança? Como o concebe? Como o interpreta? Como interage com ele? E, por fim, como chega a possuí-lo. (ibidem, p.64)

Ainda sobre sua tese de doutorado, a pesquisadora apresenta as seguintes reflexões: 
[...] acredito que não faria de novo um trabalho como o de minha tese de doutorado por várias razões, algumas delas porque têm a ver com a filosofia da época. Era uma época em que se propunham frases soltas às crianças e pedia-se a elas que interpretassem transformações que ninguém diria nunca. (ibidem, p.63)

Com tantas aspirações, Ferreiro não conseguiu ficar por muito tempo na Argentina. Nos anos de 1970, esse país passava por um sério processo de transição política. ${ }^{8}$ A situação acadêmica de Ferreiro estava comprometida, e ela não podia retornar à Universidade de Buenos Aires, da qual havia saído. ${ }^{9}$ Assim, Ferreiro e Rolando Garcia, seu marido, foram trabalhar na Universidade de Montevidéu, no Uruguai, onde passavam duas semanas e regressavam a Buenos Aires por mais duas. Naquele momento, Ferreiro relacionou os problemas que lhe interessavam do ponto de vista teórico a uma problemática da realidade:

Queria indagar que tipo de pressuposição o professor tinha em relação à competência linguística das crianças e como isso podia interferir na aprendizagem. Nessa tarefa prévia de sondagem para elaborar hipóteses mais pertinentes, comecei a perceber que uma

8 Como é sabido, a história política da Argentina é conturbada e marcada por uma série de golpes militares, como os de 1930, 1943, 1955, 1966, 1976 e 1981. A década de 1970 é marcada pela "Volta de Perón" ao poder, pois, em 1973, Juan Péron assume a presidência, mas morre em 1974, quando assume "Isabelita", sua esposa, e o país passa por ondas violentas de ataques de grupos de esquerda e de direita, além de muitas greves trabalhistas e inflação alta. Em 1976 começa a "Guerra suja”, e o general Jorge Videla assume o poder. Somente em 1983 é retomado o regime democrático, quando Raúl Alfonsín assume a presidência.

9 Não foi possível localizar a informação contendo a data exata em que Emilia Ferreiro desvinculou-se da Universidade de Buenos Aires. A informação mais próxima a esse fato encontra-se na "Nota preliminar" escrita por Ferreiro e Teberosky e publicada no livro Psicogênese da língua escrita (1985), na qual as autoras informam que no ano de 1974 desenvolveram a pesquisa sobre a psicogênese da língua escrita, vinculadamente à Universidade de Buenos Aires. 
enorme quantidade de intercâmbios linguísticos tinham a ver com a escrita. Eram intercâmbios linguísticos sobre a aprendizagem da língua escrita. (ibidem, p.17)

Ao desenvolver sua pesquisa sobre a aquisição da língua escrita com crianças, no começo da década de 1970, Ferreiro não encontrou em nenhuma delas a "criança piagetiana", ou seja, "[...] uma criança que tenta compreender o mundo que a rodeia, que formula teorias experimentais acerca desse mundo; uma criança para quem praticamente nada é estranho" (ibidem, p.18).

Segundo Ferreiro, a bibliografia sobre a aquisição da escrita que existia à época estava dividida em dois grupos: de um lado estava a bibliografia psicológica, que listava as habilidades necessárias para a aprendizagem da leitura; de outro, estava a bibliografia pedagógica, na qual se observava a antiga discussão sobre o melhor método para se ensinar a ler e a escrever.

Diante desse problema, a pesquisadora começou com uma pergunta muito vaga: "Será que no caso da língua escrita essa criança piagetiana não existe?”. E se propôs a verificar sua existência, ou não. Para isso, Ferreiro e seus colaboradores utilizaram, além do referencial piagetiano, os pressupostos da Psicolinguística no tocante à competência linguística da criança.

Em 1973, Ferreiro organizou dois grupos de pesquisa na Argentina: um com pessoas que trabalhavam com temas vinculados à escrita, com Ana Teberosky, Alicia Lenzi, Suzana Fernández, Ana María Kaufman e Delia Lerner; e outro com pessoas que trabalhavam com temas vinculados à língua oral, com Célia Jakubowitz e Liliana Tolchinsky, entre outras. Todas eram psicólogas ou pesquisadoras da área das Ciências da Educação e interessavam-se em trabalhar com Ferreiro devido a sua formação acadêmica. Ainda em comum tinham um compromisso científico de aprender com Ferreiro, pesquisar e encontrar soluções para os problemas enfrentados em relação à aprendizagem da leitura e da escrita, pois defendiam o ponto de vista de que a escola pública deveria garantir o direito à alfabetização a todas as crianças. 
Em 1974, juntamente com Ana Teberosky, Susana Fernándes, Ana Maria Kaufman, Alicia Lenzi e Liliana Tolchinsky, Ferreiro começou um trabalho experimental. Naquele ano, a pesquisadora já havia retornado às atividades docentes na Universidade de Buenos Aires, e esse primeiro ano de pesquisa fez parte de suas tarefas nessa função. Era o começo da pesquisa sobre a psicogênese da língua escrita, cujos resultados foram publicados somente em 1979, no México. Tal trabalho teve prosseguimento por mais dois anos, mesmo sem auxílio financeiro, nem oficial.

Como então se iniciava o regime militar na Argentina, as pesquisadoras tiveram dificuldades de conseguir apoio para o desenvolvimento de suas pesquisas. Com insistência, começaram o trabalho em escolas de bairros marginalizados de Buenos Aires. Em 1975, depois de dois anos e meio de trabalho, o grupo foi disperso, pois "[...] a história político-social argentina conduziu-nos à diáspora [...]" (ibidem, p.30), o que dificultou o término da coleta de dados. Cada uma das pesquisadoras partiu para um lugar diferente: Ferreiro voltou a Genebra; Ana María Kaufman foi para o México; Delia Lener, para o Brasil e, depois, Venezuela; Ana Teberosky foi para Barcelona; e outros permaneceram em Buenos Aires. Apesar de todo o constrangimento, o grupo continuava com os mesmos interesses de investigação que tinha a princípio. Começaram a se comunicar, então, por carta e descobriram a possibilidade de desenvolver estudos comparativos e multiplicarem-se.

No segundo período de permanência na capital suíça, Ferreiro conseguiu um cargo de professora adjunta na Universidade de Genebra, mas a condição de permanência para um professor estrangeiro era difícil, pois este só poderia ocupar um cargo quando liberado por outro estrangeiro e se não houvesse nenhum suíço na condição de ocupá-lo. Assim, a pesquisadora resolveu voltar à América Latina, mas não poderia ser para a Argentina.

Começou, então, a fazer viagens frequentes para o México, onde formou um grupo de estudos com Margarita Gomes Palacio. Segundo Ferreiro, esse foi o primeiro grupo mexicano criado para discutir os problemas da aquisição da leitura e da escrita e cujo tra- 
balho teve repercussão no planejamento de políticas educacionais da Secretaria da Educação Pública do México.

A escolha por esse país deu-se pelo fato de que, lá, Ferreiro encontrou novas possibilidades de continuar o trabalho com crianças e iniciar atividades com adultos analfabetos e povos indígenas, além de obter lugar de privilégio como docente, já que, em 1979, passou a atuar no Centro de Investigações e Estudos Avançados (Cinvestav) do Instituto Politécnico Nacional (IPN) do México, onde hoje é pesquisadora emérita.

Foi no México, também no ano de 1979, que Ferreiro publicou, em coautoria com Ana Teberosky, seu mais importante trabalho: Los sistemas de escritura en el desarrollo del niño, editado pela Siglo XXI Editores, contendo resultados e reflexões sobre a pesquisa realizadas na Argentina, nos anos de 1974, 1975 e 1976, com seu grupo de pesquisa. Em 1985, esse livro foi traduzido no Brasil, com o título Psicogênese da língua escrita, pela Editora Artes Médicas, ${ }^{10}$ que, no ano de 1999, lançou uma edição comemorativa de vinte anos de publicação do livro.

Mesmo antes da publicação da tradução brasileira do livro Psicogênese da língua escrita e da divulgação dos resultados na Argentina, Ferreiro começou a tratar do tema da alfabetização em nosso país, “[...] acho que em 1981 ou 1982” (ibidem, p.40).

No Brasil, os resultados foram tomados pelas pessoas que estavam lutando contra esse escândalo nacional de tantas reprovações no primeiro ano, pessoas que haviam feito uma profunda reflexão sobre os fenômenos de alfabetização - profunda pelo menos como se poderia fazer no início de 1980 - e que estavam desesperadas com essa dissociação de ser construtivista na hora da matemática e condutistas na hora da leitura e da escrita. (Penso em Telma Weisz, por exemplo, uma das primeiras pessoas que, no Brasil, entendeu

10 A editora trocou de razão social em julho de 2000, passando de Editora Artes Médicas Sul Ltda. para Artmed Editora Ltda.. Atualmente é denominada Artmed Editora S/A. 
tudo lendo-me em espanhol, antes de minha primeira "palestra" nesse país). (ibidem, p.40)

Desde então, e principalmente depois de 1985, quando seus textos começaram a ser traduzidos e divulgados, as ideias de Emilia Ferreiro sobre alfabetização estão presentes em nosso país, permanecendo no cenário brasileiro de alfabetização até os dias atuais, seja por meio dos textos traduzidos, seja por meio de sua participação em eventos científicos de repercussão nacional, seja em palestras proferidas por ela, que atraíram muitos professores. Também é considerada figura carismática entre os professores. Em 1989, um jornal de Porto Alegre escreveu a seguinte notícia:

A psicolinguista Emilia Ferreiro silenciou mais de 15 mil professores durante a palestra de quase duas horas que proferiu ontem à tarde no Gigantinho. Público semelhante somente é visto em assembleias do magistério. (Apud Ferreiro, 2001a, p.165)

Sobre essa notícia a pesquisadora comenta:

Garanto-lhe que "manter em silêncio mais de 15 mil professoras (brasileiras!) durante quase duas horas" é quase um recorde para o Guiness. (Ferreiro, 2001a, p.165)

A carreira de Ferreiro está marcada por uma série de homenagens que recebeu em diversos lugares onde suas ideias são divulgadas, fato que demonstra a grande abrangência e o reconhecimento de seu trabalho como pesquisadora em diversos países.

Em abril de 2001, Ferreiro recebeu das mãos do então presidente da República, Fernando Henrique Cardoso, a mais alta distinção do governo brasileiro na área da educação: a condecoração do "Mérito Educativo no Grau de Grande Oficial”. Na solenidade, suas ideias foram elogiadas e recomendadas pelo presidente, já que estão presentes na concepção de alfabetização adotada pelos Parâmetros 
Curriculares Nacionais (PCN), além de fazerem parte de programas oficiais de formação continuada de professores alfabetizadores.

Como se pode observar, ao longo de sua formação e atuação profissional, Ferreiro vem demonstrando seu compromisso, dedicação e preocupação com o problema da aprendizagem da leitura e da escrita. Trata-se de uma trajetória intelectual marcada a princípio pelo empenho em enfrentar suas "inquietações" e, posteriormente, pelo "reconhecimento" do fato de a pesquisadora ter contribuído por meio de suas pesquisas para a busca de soluções para os problemas da aquisição da leitura e da escrita pela criança.

\section{Bibliografia de Emilia Ferreiro}

Quando da elaboração de instrumento de pesquisa (Mello, 2001), localizei 162 referências bibliográficas de textos escritos por Emilia Ferreiro. Essas referências foram classificadas de acordo com a forma de participação da autora e o tipo de texto: 23 livros como autora, organizadora e/ou coordenadora; sete livros em coautoria; quarenta capítulos de livros; sete capítulos de livros em coautoria; 52 artigos em periódicos, "fascículo" e "memoria in extenso"; dois "informes de investigación"; cinco "informes de investigación" em coautoria; 24 artigos em periódicos e prefácio em coautoria; e duas entrevistas concedidas no Brasil. ${ }^{11}$

A fim de propiciar uma visão do conjunto dessa bibliografia, apresento, no Quadro 8, distribuídos por ano de publicação, a quantidade e os tipos dos textos escritos por essa pesquisadora entre 1969 e 2009.

11 Na classificação dos textos escritos por Emilia Ferreiro, a opção foi por conservar a terminologia utilizada nas informações que a pesquisadora me enviou, por meio de mensagem pessoal, em 30 de maio de 2001. Por essa razão, permaneceram em espanhol os seguintes termos e expressões: "fascículo", "informe de investigación" e "memoria in extenso". Estes equivaleriam, respectivamente, aos seguintes termos e expressões utilizadas no Brasil: "opúsculo", "relatório de pesquisa" e "texto completo em anais de evento". 


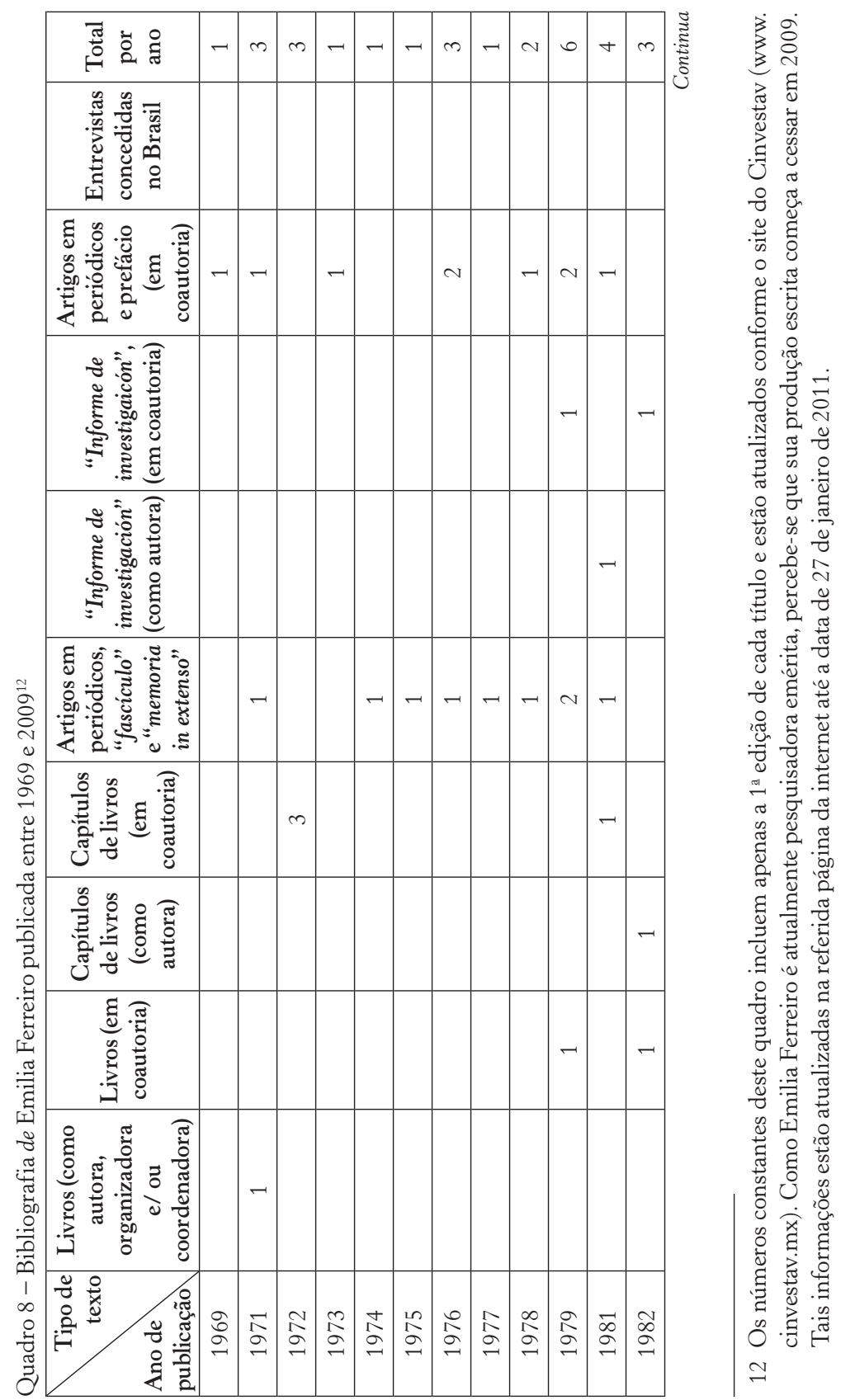




\begin{tabular}{|c|c|c|c|c|c|c|c|c|c|c|c|c|c|c|c|}
\hline 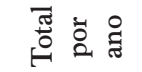 & $\infty$ & + & $\sigma$ & $\infty$ & + & $r$ & -1 & $\sim$ & in & + & 0 & $a$ & in & $\Xi$ & 0 \\
\hline 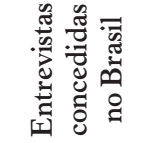 & & & & & & & & & & & & & & & \\
\hline
\end{tabular}

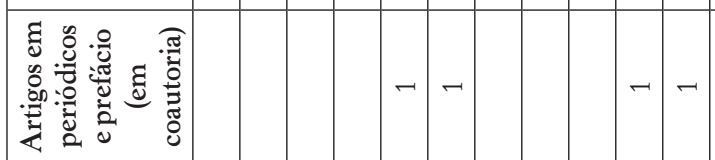

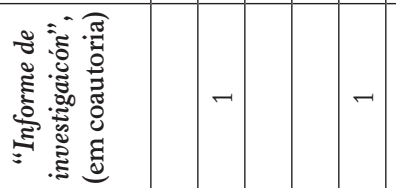

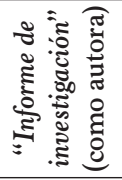

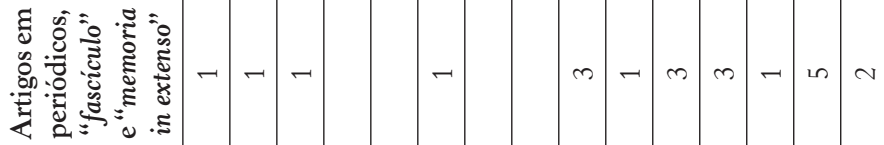

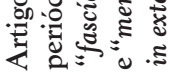

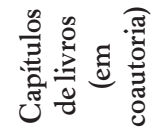

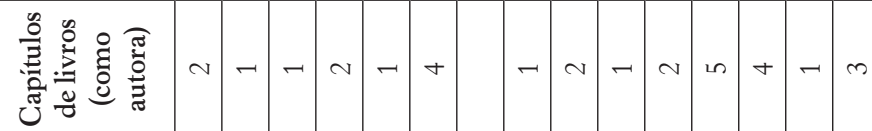

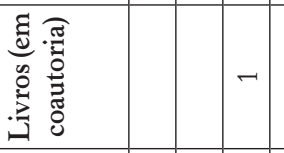

\begin{tabular}{|c|c|c|c|c|c|c|c|c|c|c|c|c|c|}
\hline 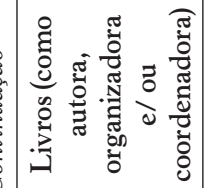 & & & -1 & -1 & - & -1 & -7 & - & - & & & - & - \\
\hline 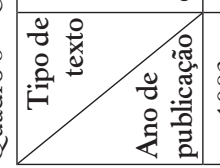 & \begin{tabular}{l|l} 
& \\
$\infty$ & \\
$\infty$ & $\vdots$ \\
$\sigma$ &
\end{tabular} & $\begin{array}{l}+ \\
\infty \\
\stackrel{\sigma}{\sigma}\end{array}$ & 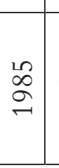 & 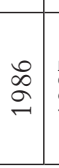 & $\begin{array}{l}\hat{\infty} \\
\stackrel{\sigma}{二}\end{array}$ & 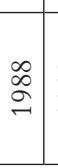 & 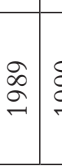 & ঃ & $\begin{array}{l}\sigma \\
\sigma \\
\sigma \\
\sigma\end{array}$ & $\stackrel{2}{\sigma}$ & $\begin{array}{l} \pm \\
\sigma \\
\sigma\end{array}$ & 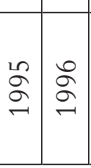 & $\hat{\sigma}$ \\
\hline
\end{tabular}




\begin{tabular}{|c|c|c|c|c|c|c|c|c|c|c|c|c|c|c|}
\hline 䒿 & in & $\infty$ & 0 & $n$ & in & in & $\sim$ & in & + & in & $m$ & $\tau$ & 1 & $\widetilde{\sigma}$ \\
\hline 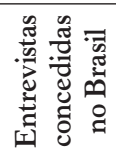 & & & & $\sim$ & & & & & & & & & $\sim$ & \\
\hline
\end{tabular}

\begin{tabular}{|c|c|c|c|c|c|c|c|c|c|}
\hline 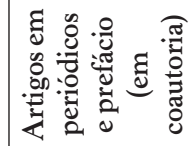 & -1 & $\sim$ & - & $\sim$ & - & - & - & $\sim$ & $\stackrel{+}{\sim}$ \\
\hline
\end{tabular}

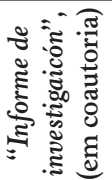

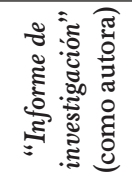

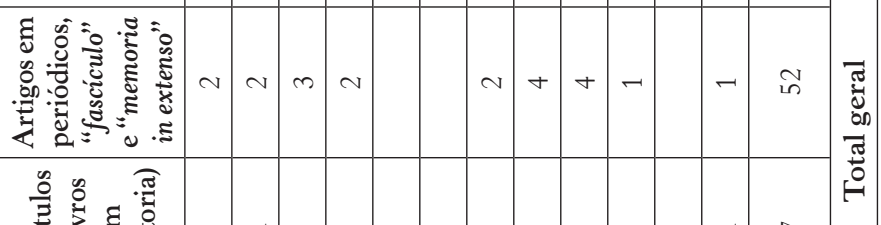

\begin{tabular}{|c|c|c|c|c|c|c|c|c|c|c|c|c|c|c|}
\hline & 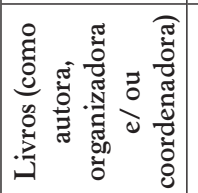 & & $\sim$ & $\rightarrow$ & $m$ & $\sim$ & + & & & & - & & & $\stackrel{?}{\sim}$ \\
\hline & 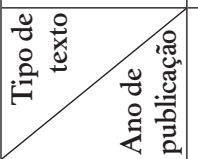 & $\begin{array}{l}\infty \\
\stackrel{\sigma}{二}\end{array}$ & $\sigma$ & $\stackrel{8}{8}$ & 홍 & ¿̊ & 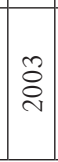 & 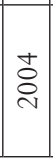 & 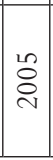 & ஓ̊ & 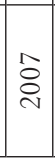 & $\begin{array}{l}\infty \\
0 \\
0 \\
0\end{array}$ & 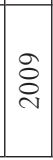 & 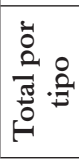 \\
\hline
\end{tabular}


Os dados apresentados no Quadro 8 permitem constatar a vasta e regular produção escrita de Emilia Ferreiro ao longo de sua atuação profissional. Desde 1969 até os dias atuais, a pesquisadora não teve textos publicados somente nos anos de 1970 e 1980.

Sua primeira publicação foi um artigo em francês no ano de 1969, em coautoria com Hermine Sinclair. Em 1971, publicou seu primeiro livro resultante da tese de doutorado concluída em 1970: Les relations temporelles dans le langage de l'enfant; cujo prefácio de Jean Piaget destacou a notável contribuição da pesquisadora para o estudo do desenvolvimento linguístico da criança e das relações entre esse desenvolvimento e as operações ou pré-operações da inteligência (Ferreiro, 2001a, p.169).

Seu segundo livro, Los sistemas de escritura en el desarrollo del niño, foi publicado em 1979, no México, em coautoria com Ana Teberosky. Essa publicação não apenas marca o início de uma série de publicações ininterruptas dos textos de Ferreiro em vários idiomas ${ }^{13}$ como também se caracteriza como um marco no âmbito tanto da produção intelectual e do pensamento da pesquisadora quanto do pensamento contemporâneo sobre alfabetização.

Pode-se observar, também no Quadro 8, um aumento considerável das publicações da pesquisadora ao longo dos anos. São 22 textos até a década de 1970, um número considerável, já que nessa década enfrentou inúmeros problemas, como a impossibilidade de permanência na Argentina, a falta de condições de permanência em Genebra, até, por fim, se instalar no México. Na década de 1980, com sua atuação profissional mais estável, publicou 33 textos, e já no final do século XX, alcançou o maior número de publicações, 59.

13 A autora publicou livros e capítulos de livros nos seguintes idiomas e pelas seguintes editoras: em espanhol: Siglo XXI, Gedisa, Paidos, Fondo de Cultura Econômica e Aique; em português: Artes Médicas/Artmed, Ática e Cortez; em inglês: Cambridge University Press, Heineman, Ablex, Pergamon Press, John Benjamins, Lawrence Erlbaum, Mouton, Hampton Press e Falmer Press; em Italiano: Nuova Italia Editrice; em francês: Presses Univeritaires de France, Nathan, Presses Universitaires de Lyon, Peeters, Presse Universitaires de Bordeaux e Droz. 
Do ano de 2000 até 2009, Emilia Ferreiro teve publicados 46 textos, o que confirma não só a permanência, mas também a vitalidade das ideias da pesquisadora, que não altera nem reescreve seus escritos anteriores. O que a pesquisadora faz são acréscimos às reflexões iniciais, os quais representam unidade e continuidade do que já se pode denominar de "obra de Emilia Ferreiro".

Entre os pesquisadores que publicaram textos em coautoria com Emilia Ferreiro encontram-se Jean Piaget e seus ex-colaboradores no Centro Internacional de Epistemologia Genética, além de pesquisadores de diversas nacionalidades: suíços, italianos, argentinos, mexicanos e espanhóis.

Em nosso país, além de Psicogênese da língua escrita, outro livro da pesquisadora que obteve considerável receptividade foi publicado também no ano de 1985, pela Editora Cortez, São Paulo, sob o título Reflexões sobre alfabetização. Trata-se de uma coletânea de quatro artigos - apenas o segundo deles, "A compreensão do sistema de escrita: construções originais da criança e informação específica dos adultos", foi escrito em coautoria com Ana Teberosky - traduzidos por Horacio Gonzales, Maria Amélia de Azevedo Golberg, Maria Antônia Cruz Costa Magalhães, Mansa do Nascimento Paro e Sara Cunha Lima. ${ }^{14}$ Comparativamente ao livro anterior, essa coletânea teve um número bem maior de edições, talvez em decorrência de certas características, como formato pequeno, poucas páginas, além de conter uma síntese das conclusões da pesquisa desenvolvida por Ferreiro e colaboradores.

Depois desses, outros oito livros foram traduzidos em nosso país, além de quatro artigos, quatro capítulos de livros e duas entrevistas, totalizando vinte títulos. No Quadro 9, apresento o número e o ano de publicação de textos de Ferreiro traduzidos no Brasil entre 1985 e 2009.

14 A mais recente edição localizada (24a edição, 2001) foi atualizada. A partir da $23^{\circ}$ edição, o título do último artigo foi alterado de "Deve-se ou não se deve ensinar a ler e escrever na pré-escola?" para "O espaço da leitura e da escrita no contexto escolar". 
Quadro 9 - Traduções brasileiras dos textos de Emilia Ferreiro entre 1985 e $2009^{15}$

\begin{tabular}{|c|c|c|c|c|c|c|}
\hline $\begin{array}{l}\begin{array}{r}\text { Tipo de } \\
\text { texto }\end{array} \\
\text { Ano de } \\
\text { publicação }\end{array}$ & $\begin{array}{l}\text { Livros como } \\
\text { autora, } \\
\text { organizadora } \\
\text { e/ ou } \\
\text { coordenadora }\end{array}$ & $\begin{array}{c}\text { Livros em } \\
\text { coautoria e } \\
\text { organizadora } \\
\text { em coautoria }\end{array}$ & $\begin{array}{c}\text { Capítulos } \\
\text { de livros }\end{array}$ & $\begin{array}{l}\text { Artigos } \\
\text { em } \\
\text { periódicos }\end{array}$ & $\begin{array}{c}\text { Entrevistas } \\
\text { concedidas } \\
\text { no Brasil }\end{array}$ & $\begin{array}{l}\text { Total } \\
\text { por } \\
\text { ano }\end{array}$ \\
\hline 1985 & 1 & 1 & & 1 & & 3 \\
\hline 1986 & 1 & & & & & 1 \\
\hline 1987 & & 1 & & & & 1 \\
\hline 1990 & 1 & & & & & 1 \\
\hline 1992 & 1 & & & & & 1 \\
\hline 1994 & & & & 1 & & 1 \\
\hline 1995 & & & 3 & & & 3 \\
\hline 1996 & & 1 & & & & 1 \\
\hline 2001 & 2 & & & 1 & 2 & 5 \\
\hline 2002 & 1 & & & & & 1 \\
\hline 2003 & 1 & & & & & 1 \\
\hline 2004 & & & & 1 & & 1 \\
\hline $\begin{array}{c}\text { Total por } \\
\text { tipo de } \\
\text { texto }\end{array}$ & 8 & 3 & 3 & 4 & 2 & 20 \\
\hline \multicolumn{5}{|c|}{ Total geral } & & 20 \\
\hline
\end{tabular}

Fonte: Mello (2001; 2011).

Desses textos constantes no Quadro 9, cinco foram publicados na década de 1980. Três deles foram publicados no ano de 1985: um livro em coautoria (Psicogênese da língua escrita), outro como autora (Reflexões sobre alfabetização ${ }^{16}$ e um artigo ("A representação da linguagem e o processo de alfabetização") em uma das mais importantes revistas especializadas em educação, com circulação nacional, Cadernos de pesquisa, da Fundação Carlos Chagas, São Paulo. Em 1986, Ferreiro teve publicado um livro como autora (Alfabetização em processo), e, em 1987, um livro coordenado em coautoria (Os processos de leitura e escrita: novas perspectivas).

15 Foi considerada somente a 1a edição de cada um dos títulos de livros para a organização do Quadro 8.

16 Embora um dos artigos dessa coletânea tenha sido escrito em coautoria com Ana Teberosky, optei por considerá-lo como de autoria de Emilia Ferreiro, pois é seu nome que se encontra registrado na capa e na ficha catalográfica da coletânea. 
Na década de 1990 foram sete títulos publicados no Brasil e traduzidos para a língua portuguesa, sendo um livro organizado por Ferreiro em 1990 (Os filhos do analfabetismo: propostas para a alfabetização escolar na América Latina), um de autoria de Ferreiro em 1992 (Com todas as letras) e um artigo também de sua autoria em 1994 ("Luria e o desenvolvimento da escrita na criança"), também publicado em Cadernos de pesquisa. Em 1995 foram publicados três capítulos de livros ("Sobre a necessária coordenação entre semelhanças e diferenças", "Desenvolvimento da alfabetização: psicogênese" e "O que está escrito em uma frase escrita? uma resposta desenvolvimentista") e, em 1996, um livro em coautoria (Chapeuzinho Vermelho aprende a escrever: estudos psicolinguísticos comparativos em três línguas).

Além desses títulos traduzidos para a língua portuguesa, tem-se um texto em espanhol ("Lengua oral y lengua escrita: aspectos de la adquisición de la representación escrita del lenguaje"), publicado nos anais do IX Congresso Internacional da Associação de Linguística e Filologia da América Latina (Alfal), realizado em agosto de 1990 pela Universidade Estadual de Campinas (Unicamp), e publicado em 1993.

No ano de 2001, Emilia Ferreiro teve cinco publicações, sendo um artigo em 2001 ("O mundo digital e o anúncio do fim do espaço institucional escolar"), dois livros como autora (Cultura escrita e educação e Atualidade de Jean Piaget) e duas entrevistas concedidas ("O ato de ler evolui" e "Significado da escrita no mundo atual"). Em 2002, teve publicado um livro como autora (Passado e presente dos verbos ler e escrever).

Já em 2003, Ferreiro coordenou a publicação do livro Relações de (in)dependência entre oralidade e escrita, pela editora Artmed. Por fim, em 2004, o artigo de sua autoria "Uma reflexão sobre a língua oral e a aprendizagem da língua escrita" foi publicado pela revista Pátio.

As traduções brasileiras das publicações de Emilia Ferreiro relacionam-se diretamente com a crescente influência do pensamento dessa pesquisadora no que se refere a propostas e práticas de alfabetização em nosso país. 
Desde o início da divulgação do pensamento construtivista de Emilia Ferreiro sobre alfabetização no Brasil, em meados dos anos de 1980, as tensões decorrentes da apropriação desse pensamento no âmbito de propostas oficiais estavam relacionadas com as discussões sobre o significado da "revolução conceitual" proposta pela autora. Embora essa tensão pareça ter-se amenizado e embora não se tenham notícias de que a pesquisa de Ferreiro e colaboradores tenha sido refutada em seus fundamentos e resultados, vêm sendo apresentadas muitas críticas relacionadas, sobretudo, à dúvida a respeito do papel do ensino, da escola e do professor desse ponto de vista.

Tais dúvidas relacionam-se com o fato de no livro Psicogênese da língua escrita não se encontrar uma proposta didática de alfabetização, nem "receitas prontas" com intenção de garantir o sucesso da alfabetização de todas as crianças em fase inicial de escolarização.

\section{Bibliografia sobre o pensamento construtivista de Emilia Ferreiro sobre alfabetização}

No que se refere à bibliografia sobre o pensamento construtivista de Emilia Ferreiro sobre alfabetização, foram reunidas e ordenadas até o final da investigação que realizei dez referências bibliográficas de textos produzidos no Brasil que tratam de Emilia Ferreiro, sua atuação profissional e sua obra, a saber: uma dissertação de mestrado de 1990; duas dissertações de mestrado de 1991; uma dissertação de mestrado de 2003; dois livros de 1993; um livro de 1997; uma tese de doutorado de 1998; um livro de 1999; e um livro de 2007.

Como critério para a seleção dos títulos que mais se aproximavam de meus objetivos de pesquisa, optei pelos que tematizam o pensamento construtivista de Emilia Ferreiro sobre alfabetização, considerando apenas as pesquisas e os estudos realizados por brasileiros com finalidade de obtenção de título acadêmico de mestrado e doutorado, assim como os textos publicados sob a forma de livro resultantes dessa produção acadêmica, com exceção do livro de 
Maria da Graça Azenha, Construtivismo: de Piaget a Emilia Ferreiro, de 1993, em que se encontra uma abordagem das contribuições de Emilia Ferreiro e colaboradores, assim como de Piaget, para os estudos teóricos sobre alfabetização, mas não se trata de resultado de texto para obtenção de título acadêmico, pois foi publicado entre as pesquisas de mestrado e doutorado de Azenha.

Analisando essas publicações, pude constatar que se pautam, principalmente, no livro Los sistemas de escritura en el desarrollo del niño e em sua tradução no Brasil: Psicogênese da língua escrita (1985). Deixei de analisar, assim, um grande número de textos que abordam o referencial teórico de Emilia Ferreiro com sua faceta voltada para a aplicação pedagógica.

Apresentam-se no Quadro 10, distribuídos por ano de publicação, a quantidade e os tipos de textos sobre o pensamento construtivista de Emilia Ferreiro sobre alfabetização produzidos no Brasil entre 1990 (ano de defesa da primeira dissertação) e 2007 (ano de publicação do último livro localizado).

Quadro 10 - Bibliografia (brasileira) sobre o pensamento construtivista de Emilia Ferreiro sobre alfabetização entre 1990 e $2007^{17}$

\begin{tabular}{|c|c|c|c|c|}
\hline $\begin{array}{l}\text { Ano de Tipo de texto } \\
\text { publicação }\end{array}$ & Livros & Tese & Dissertações & $\begin{array}{c}\text { Total por } \\
\text { ano }\end{array}$ \\
\hline 1990 & & & 1 & 1 \\
\hline 1991 & & & 2 & 2 \\
\hline 1993 & 2 & & & 2 \\
\hline 1997 & 1 & & & 1 \\
\hline 1998 & & 1 & & 1 \\
\hline 1999 & 1 & & & 1 \\
\hline 2003 & & & 1 & 1 \\
\hline 2007 & 1 & & & 1 \\
\hline Total por tipode texto & 5 & 1 & 4 & \\
\hline \multicolumn{2}{|c|}{ Total geral } & & 10 \\
\hline
\end{tabular}

Fonte: Mello (2001; 2011).

17 Foram consideradas apenas a 1르 edição de cada título de livro. 
Nos quadros 11 e 12, essa mesma bibliografia é apresentada, no entanto, organizada respectivamente por tese/dissertações e livros.

O primeiro texto sobre o pensamento construtivista de Emilia Ferreiro sobre alfabetização é uma dissertação de mestrado, elaborada por Colello (1990), defendida na Universidade de São Paulo (USP) sob a orientação de Maria de Lourdes Ramos da Silva e intitulada Linguagem escrita e escrita da linguagem Emilia Ferreiro e Jean Le Boulch: um confronto de teorias. Nessa dissertação, a pesquisa-

Quadro 11 - Dissertações e teses sobre o pensamento construtivista de Emilia Ferreiro sobre alfabetização defendidas no Brasil, por nível, instituição, título, autor e orientador, entre 1990 e 2003

\begin{tabular}{|c|c|c|c|c|c|}
\hline Ano & Nível & Instituição & Título & Autor & $\begin{array}{c}\text { Orientador } \\
\text { (A) }\end{array}$ \\
\hline 1990 & Mestrado & USP & $\begin{array}{l}\text { Linguagem escrita e } \\
\text { escrita da linguagem } \\
\text { - Emilia Ferreiro e } \\
\text { Jean Le Boulch: um } \\
\text { confronto de teorias }\end{array}$ & $\begin{array}{l}\text { Silvia de } \\
\text { Mattos } \\
\text { Gasparian } \\
\text { Colello }\end{array}$ & $\begin{array}{l}\text { Maria de } \\
\text { Lourdes } \\
\text { Ramos da } \\
\text { Silva }\end{array}$ \\
\hline 1991 & Mestrado & PUC/SP & $\begin{array}{c}\text { Problemas da } \\
\text { abordagem } \\
\text { piagetiana em } \\
\text { educação: Emilia } \\
\text { Ferreiro e a } \\
\text { alfabetização }\end{array}$ & $\begin{array}{c}\text { Vera } \\
\text { Maria } \\
\text { Masagão } \\
\text { Ribeiro }\end{array}$ & $\begin{array}{c}\text { Miriam } \\
\text { Jorge Warde }\end{array}$ \\
\hline 1991 & Mestrado & USP & $\begin{array}{l}\text { O grafismo infantil: } \\
\text { processos e } \\
\text { perspectivas }\end{array}$ & $\begin{array}{c}\text { Maria } \\
\text { da Graça } \\
\text { Azenha } \\
\text { Bautzer } \\
\text { Santos }\end{array}$ & $\begin{array}{l}\text { Marta Kohl } \\
\text { de Oliveira }\end{array}$ \\
\hline 1998 & Doutorado & PUC/SP & $\begin{array}{c}\text { A prática pedagógica } \\
\text { dos alfabetizadores } \\
\text { de jovens e adultos: } \\
\text { contribuições de } \\
\text { Freire, Ferreiro e } \\
\text { Vygotsky } \\
\end{array}$ & $\begin{array}{l}\text { Tânia } \\
\text { Maria } \\
\text { de Melo } \\
\text { Moura }\end{array}$ & $\begin{array}{c}\text { Casali } \\
\text { Alipio } \\
\text { Marcio Dias }\end{array}$ \\
\hline 2003 & Mestrado & Unesp & $\begin{array}{c}\text { Um estudo sobre } \\
\text { o pensamento } \\
\text { construtivista de } \\
\text { Emilia Ferreiro sobre } \\
\text { alfabetização }\end{array}$ & $\begin{array}{l}\text { Márcia } \\
\text { Cristina } \\
\text { de } \\
\text { Oliveira } \\
\text { Mello }\end{array}$ & $\begin{array}{l}\text { Maria do } \\
\text { Rosário } \\
\text { Longo } \\
\text { Mortatti }\end{array}$ \\
\hline
\end{tabular}

Fonte: Mello (2001; 2011). 
Quadro 12 - Livros publicados no Brasil sobre o pensamento construtivista de Emilia Ferreiro sobre alfabetização, por editora, título e autor, entre 1993 e 2007

\begin{tabular}{|c|c|c|c|}
\hline Ano & Editora & Título & Autor \\
\hline 1993 & Papirus & $\begin{array}{c}\text { Ensinar ou aprender? Emilia Ferreiro e a } \\
\text { alfabetização }\end{array}$ & $\begin{array}{c}\text { Vera Maria } \\
\text { Masagão Ribeiro }\end{array}$ \\
\hline 1993 & Ática & $\begin{array}{c}\text { Construtivismo: de Piaget a Emilia } \\
\text { Ferreiro }\end{array}$ & $\begin{array}{c}\text { Maria da Graça } \\
\text { Azenha }\end{array}$ \\
\hline 1995 & Ática & $\begin{array}{c}\text { Imagens e letras: os possíveis acordos de } \\
\text { Ferreiro e Luria }\end{array}$ & $\begin{array}{c}\text { Maria da Graça } \\
\text { Azenha }\end{array}$ \\
\hline 2007 & Enesp & $\begin{array}{c}\text { Alfabetização de adultos: Freire, } \\
\text { Ferreiro, Vygotsky - contribuições } \\
\text { teórico-metodológicas - a formulação de } \\
\text { propostas pedagógicas }\end{array}$ & $\begin{array}{c}\text { Tânia Maria de } \\
\text { Melo Moura }\end{array}$ \\
\hline língua escrita
\end{tabular}

Fonte: Mello (2001; 2011).

dora aponta o problema do fracasso escolar em nosso país, sobretudo na fase de alfabetização de crianças, decorrente dos métodos e recursos utilizados pelos professores que impossibilitam aos alunos obter êxito na "conquista da língua escrita", o que ocasiona evasão e repetência; aqueles que "sobrevivem" não apresentam uma aprendizagem significativa. Com o objetivo de "[...] repensar a alfabetização, sem perder de vista a figura central do processo educativo: o aluno [...]" (ibidem, p.3), a pesquisadora faz um estudo sobre a alfabetização, confrontando as ideias de Emilia Ferreiro sobre a psicogênese da língua escrita com as de Le Boulch, em sua Psicocinética.

A autora apresenta, ainda, as teorias de Emilia Ferreiro e de Le Boulch, destacando os objetivos e as propostas básicas de ambos, e conclui que devemos considerar no processo de alfabetização tanto os "aspectos cognitivos" abordados por Emilia Ferreiro quanto a “evolução percepto-motora” proposta por Le Boulch, pois é possível, na prática, a complementaridade das duas teorias.

Conforme podemos observar nos quadros 10, 11 e 12, esse é o único estudo, dentre os localizados, que ainda não foi publicado sob a forma de livro. 
Em 1991, tem-se a defesa de uma dissertação de mestrado intitulada Problemas da abordagem piagetiana em educação: Emilia Ferreiro e a alfabetização, que foi defendida por Vera Maria Masagão Ribeiro, na Pontifícia Universidade Católica (PUC) de São Paulo, sob a orientação de Miriam Jorge Warde.

Ribeiro faz uma análise do estudo de Emilia Ferreiro sobre a teoria da psicogênese da língua escrita, suas contribuições e as limitações de sua abordagem no campo educacional, principalmente da alfabetização. Para tanto, analisa o referencial teórico utilizado por Ferreiro, especialmente a teoria piagetiana, "[...] procurando determinar quais os elementos de seu pensamento que são caudatários dessa matriz teórica e quais as novidades que lhe aportam" (Ribeiro, 1991, p.10). Para analisar a psicogênese da língua escrita estabelecida por Emilia Ferreiro, Ribeiro pauta-se no livro Los sistemas de escritura en el desarrolo del niño, de 1979, além de citar outros textos de autoria de Ferreiro.

A autora constata que os estudiosos da teoria piagetiana não trouxeram "elementos significativos" para o estudo da aprendizagem da leitura e da escrita, sendo inédita a abordagem de Emilia Ferreiro e colaboradores graças à junção com a Psicolinguística contemporânea. A autora descreve, ainda, as marcas do pensamento piagetiano contidas nos estudos de Ferreiro, como o conceito de "sujeito epistêmico" e de "conflito cognitivo", e a abordagem sobre o processo de desenvolvimento, entre outros.

Ribeiro destaca também a importância da pesquisa de Ferreiro, mas alerta sobre o erro de se considerarem as produções infantis como espontâneas, já que as crianças envolvidas na pesquisa de Emilia Ferreiro e colaboradores estavam em situação experimental. E se, de acordo com a concepção de Ferreiro, o processo de ensino deve "plagiar" esse processo de desenvolvimento espontâneo, Ribeiro indaga, então, qual o papel do ensino, concluindo que existe negação total desse papel na obra de Ferreiro, pois não se encontra nela "[...] uma explicação de como a intervenção alfabetizadora interage ou pode interagir com esse processo espontâneo [...]” (ibidem, p.69). 
Datada também do ano de 1991, tem-se uma dissertação de mestrado intitulada $O$ grafismo infantil: processos e perspectivas, defendida por Santos, ${ }^{18}$ na Universidade de São Paulo (USP), sob a orientação de Marta Kohl de Oliveira.

Tomando como objeto da pesquisa a gênese da escrita na criança, Santos (1991) utiliza o referencial teórico de Emilia Ferreiro e o texto "O desenvolvimento da escrita na criança", do pesquisador soviético Alexander Romanovich Luria, para fazer a interpretação dos dados coletados, por meio de acompanhamento longitudinal entre crianças de 4 e 6 anos que frequentavam escolas de educação infantil, na cidade de São Paulo, entre os anos de 1988 e 1990. A pesquisadora acompanha as produções escritas das crianças, comparando as abordagens de Luria e Ferreiro.

Essa comparação, segundo Azenha (1995, p.9), possibilita uma “[...] análise de episódios empíricos vinculados à aquisição da escrita $[\mathrm{e}]$ permite ainda o estabelecimento dos pontos em que haja competição ou semelhanças entre as linhas de interpretação". A pesquisadora discute essas teorias colocando em evidência os pontos convergentes e os confrontos entre elas e conclui que a pesquisa aponta evidências sobre

[...] como se constrói o uso simbólico do grafismo com o cotejo de dois polos: o produto gráfico exibido pela criança e a forma pela qual se processam e se constituem atividades psicológicas complexas relacionadas à aquisição da escrita. (ibidem, p.179)

Além dessa pesquisa, Azenha teve publicado, no ano de 1993, o livro Construtivismo: de Piaget a Emilia Ferreiro, no qual apresenta dados biográficos de Jean Piaget, dá ênfase à "origem de seus principais postulados", explica as noções centrais de sua teoria do desenvolvimento da inteligência e faz uma "[...] análise das investi-

18 Trata-se de Maria da Graça Azenha Santos, que em textos posteriores passou a assinar Maria da Graça Azenha. 
gações realizadas por Emilia Ferreiro para estabelecer a origem das noções da escrita e da leitura na criança" (idem, 1993, p.6).

A pesquisadora apresenta, também, alguns dados biográficos de Emilia Ferreiro e informa que no livro Psicogênese da língua escrita estão contidas ideias que mudaram o panorama da alfabetização no Brasil, além de terem representado “[...] uma grande revolução conceitual nas referências teóricas com que se tratava a alfabetização até então, iniciando a instauração de um novo paradigma para a interpretação da forma pela qual a criança aprende a ler e a escrever" (ibidem, p.35).

Ao analisar os principais resultados da pesquisa sobre a psicogênese da língua escrita, Azenha (ibidem) explica como esses dados foram coletados por Ferreiro e colaboradores e faz comentários "[...] sobre as interpretações que estes dados têm suscitado em relação à questão educacional e algumas deduções plausíveis para a prática alfabetizadora [...]" (ibidem, p.87), assim como os equívocos da interpretação dos resultados apresentados cometidos por professores.

A tese de doutorado intitulada Alfabetização de adultos: Freire, Ferreiro, Vygotsky - contribuições teórico-metodológicas - a formulação de propostas pedagógicas, defendida em 1998 por Tânia Maria de Melo Moura, na PUC/SP, sob a orientação de Casali Alipio Marcio Dias, traz informações sobre a falta de referencial teórico entre os profissionais da área de alfabetização de jovens e adultos no estado de Alagoas e também em outros estados do Brasil, apontando que esse fato provoca uma "[...] inconsistência nas práticas [...]” (Moura, 1998, p.11), levando os professores a utilizarem em suas práticas os chamados "métodos tradicionais", misturados com os "caminhos metodológicos" percorridos por Paulo Freire nas décadas de 1950 e 1960, além de introduzirem elementos do "construtivismo" de Emilia Ferreiro e "[...] algumas práticas [que] já se anunciam "vygotskyanas”” (ibidem, p.11).

Frente a esse problema, Moura (ibidem) se propõe a analisar os referenciais teóricos sobre alfabetização contidos nas concepções do educador brasileiro Paulo Freire, da pesquisadora argentina Emilia 
Ferreiro e do psicólogo soviético Vygotsky, ${ }^{19}$ assim como destacar as contribuições de cada um deles para compreender de "[...] forma científica o processo de alfabetização [...]” (ibidem, p.11),e, a partir disso, fornecer subsídios para que os profissionais envolvidos no processo de alfabetização de adultos possam reformular as propostas pedagógicas.

Por fim, em Um estudo sobre o pensamento construtivista de Emilia Ferreiro sobre alfabetização, Mello (2003) apresenta as concepções a respeito do processo de construção do conhecimento da língua escrita, por parte de crianças, que resultam da pesquisa de Emilia Ferreiro sobre a psicogênese da língua escrita fundamentada na Epistemologia Genética de Jean Piaget e na Psicolinguística de Noam Chomsky e que tiveram significativa repercussão em nosso país a partir de meados dos anos de 1980. Por meio da análise da configuração textual do livro Psicogênese da língua escrita, a pesquisa propiciou tanto uma avaliação mais precisa da importância e do significado do pensamento dessa pesquisadora quanto a constatação de que a matriz invariante de seu pensamento encontra-se no livro analisado.

Os trabalhos de Colello, Ribeiro, Azenha, Moura e Mello totalizam, como foi exposto no início deste tópico, as dez referências de textos localizados, até o momento, em que se tematizam aspectos do pensamento construtivista de Emilia Ferreiro sobre alfabetização, trazendo grande contribuição aos estudos sobre o tema e especialmente sobre a pesquisa de Emilia Ferreiro e colaboradores.

Nos estudos e pesquisas realizados na década de 1990, época em que ainda eram recentes as propostas institucionais de "mudanças" no sentido de se superar o problema do analfabetismo no país, o denominador comum eram as ideias de Emilia Ferreiro e sua concepção sobre a psicogênese da escrita na criança, contida, sobretudo, no livro Psicogênese da língua escrita.

19 Mantenho aqui a grafia "Vygotsky" utilizada pela pesquisadora. Outros pesquisadores brasileiros optam pela grafia "Vigotski". 
Em estudos mais recentes, Mello (2003; 2007), no âmbito do Grupo de Pesquisa "História o Ensino da Língua e Literatura no Brasil” (GPHELLB), destaca a matriz invariante do pensamento de Ferreiro, contida no livro Psicogênese da língua escrita, como impulsionadora de sua contribuição como sujeito da história da alfabetização no Brasil.

\section{Considerações finais}

A participação de uma estrangeira na história da alfabetização no Brasil é a de uma intelectual que, na busca de soluções para modificar a realidade do contexto educacional dos países da América Latina em relação ao fracasso na alfabetização principalmente das crianças das classes sociais menos favorecidas, encontrou no país um campo profícuo para apresentar e discutir seu pensamento, especialmente depois da divulgação dos resultados de pesquisas contidos no livro Psicogênese da língua escrita, em que se encontra uma nova maneira de se pensar a alfabetização, já que, para a pesquisadora, o fracasso na alfabetização está relacionado com a maneira que esse processo é proposto e praticado.

Tendo em vista essas considerações, Ferreiro afirma ter feito uma "revolução conceitual" a respeito da alfabetização, por ter "mudado" o eixo em torno do qual passavam as discussões sobre o tema: dos debates sobre os métodos e os testes utilizados para o ensino da leitura e da escrita para a ideia de que não são os métodos que alfabetizam, nem os testes que auxiliam o processo de alfabetização, mas são as crianças que (re)constroem o conhecimento sobre a língua escrita por meio de hipóteses que formulam para compreender o funcionamento desse objeto de conhecimento.

Além dessa proposta de "mudança de olhar" sobre o processo de alfabetização, a "revolução conceitual” proposta está, também, relacionada com a própria concepção de língua escrita e de alfabetização. Para Ferreiro, a língua escrita deve ser entendida como um sistema de representação da linguagem, que se opõe à ideia de que 
a língua escrita é considerada como codificação e decodificação da linguagem.

Consequentemente, Ferreiro opõe-se ao conceito de alfabetização entendido como a aprendizagem de duas técnicas diferentes (codificar e decodificar a língua escrita), em que o professor é o único informante autorizado. Ferreiro defende, então, o conceito de alfabetização que vai em sentido contrário, já que considera a alfabetização como o processo de aprendizagem da língua escrita. Essa aprendizagem, considerada também "aprendizagem conceitual”, dá-se por meio da interação entre o objeto de conhecimento (a língua escrita) e o sujeito cognoscente.

As dúvidas, tensões e discussões sobre o significado do pensamento construtivista sobre alfabetização e da "revolução conceitual" proposta por Ferreiro não eliminaram sua representatividade como sujeito da história da alfabetização no Brasil. De um ponto de vista histórico, deve-se incontestavelmente à centralidade do pensamento de Emilia Ferreiro na fundação de uma nova tradição no ensino inicial de leitura e escrita no Brasil, cujas marcas podem-se reconhecer até os dias atuais, como destacam Magnani (1997) e Mortatti (2000; 2007).

\section{Referências bibliográficas}

AZENHA, M da G. Construtivismo: de Piaget a Emilia Ferreiro. São Paulo: Ática, 1993. (Série Princípios, n.235).

Imagens e letras: os possíveis acordos de Ferreiro e Luria. São Paulo: Ática, 1995.

CABRAL, Á; NICK, E. Dicionário técnico de Psicologia. 10.ed. São Paulo: Cultrix, 1998.

COLELLO, S. de M. G. Linguagem escrita e escrita da linguagem: Emilia Ferreiro e Jean Le Boulch: um confronto de teorias. São Paulo, 1990. 149f. Dissertação (Mestrado em Educação) - Universidade de São Paulo.

FERREIRO, E. Les relations temporelles dans le langage de l'enfant. Genève: Librairie Droz, 1971. 
Cultura escrita e educação: conversas de Emilia Ferreiro com José Antonio Castorina, Daniel Goldin e Rosa María Torres. Tradução de Ernani Rosa. Porto Alegre: Artmed, 2001a.

Ficha Bibliográfica [mensagem pessoal]. Mensagem recebida por <donizeti.fast@ig.com.br> em 30 maio 2001b.

Curricumum vitae [mensagem pessoal]. Mensagem recebida por <donizeti.fast@ig.com.br> em 30 maio 2001c.

; TEBEROSKY, A. Psicogênese da língua escrita. Tradução de Diana M. Linchestein et al. Porte Alegre: Artes Médicas, 1985.

HARRIS, T. L.; HODGES, R. E. (orgs.). Dicionário de alfabetização: vocabulário de leitura e escrita. Tradução de Beatriz Viegas Farias. Porto Alegre: Artmed, 1999.

LYONS, J. As ideias de Chomsky. Tradução de Otanny Silveira da Mota e Leonidas Hegenberg. São Paulo: Cultrix, 1976.

MAGNANI, M. do R. M. Os sentidos da alfabetização: a "questão dos métodos" e a constituição de um objeto de estudo (São Paulo: 1876/1994). Presidente Prudente, 1997. 389f. Tese (Livre-Docência

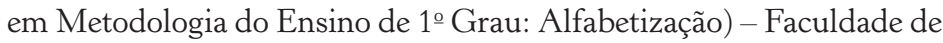
Ciência e Tecnologia, Universidade Estadual Paulista.

MELLO, M. C. de O. Bibliografia de Emilia Ferreiro e sobre seu pensamento construtivista sobre alfabetização. Relatório parcial de pesquisa. Universidade Estadual Paulista, Marília, 2001.

Um estudo sobre o pensamento construtivista de Emilia Ferreiro sobre alfabetização. Marília, 2003. Dissertação (Mestrado em Educação) - Universidade Estadual Paulista.

Emilia Ferreiro e a alfabetização no Brasil: um estudo sobre a Psicogênese da língua escrita. São Paulo: Editora Unesp, 2007.

Bibliografia de e sobre Emilia Ferreiro: um instrumento de pesquisa. Relatório parcial de pesquisa. Universidade Estadual Paulista, Marília, 2011.

MORTATTI, M. do R. L. Os sentidos da alfabetização: São Paulo1876/1994. São Paulo: Editora Unesp; Brasília: MEC/Inep/Comped, 2000.

MOURA, T. M. de M. Alfabetização de adultos: Freire, Ferreiro, Vygotsky - contribuições teórico-metodológicas - a formulação de propostas pedagógicas. São Paulo, 1998. Tese (Doutorado - Programa de Supervisão e Currículo) - Pontifícia Universidade Católica de São Paulo.

PIAGET, J. A Epistemologia Genética. In: Piaget. Tradução de Nathanael C. Caixeiro. São Paulo: Abril Cultural, 1978, p.1-64. (Coleção "Os Pensadores"). 
RIBEIRO, V. M. Problemas da abordagem piagetiana em educação: Emilia Ferreiro e a alfabetização. São Paulo, 1991. 109f. Dissertação (Mestrado em Filosofia da Educação) - Pontifícia Universidade Católica de São Paulo.

SANTOS, M. da G. A. B. O grafismo infantil: processos e perspectivas. São Paulo, 1991. 207f. Dissertação (Mestrado em Educação) - Faculdade de Educação, Universidade de São Paulo. 


\section{4 \\ JoÃo Wanderley Geraldi (1946-) \\ E O TEXTO NA SALA DE AULA ${ }^{1}$}

Luzia de Fátima Paula

\section{Introdução}

Neste texto, focaliza-se a importância da contribuição do pensamento de João Wanderley Geraldi (1946- ) para o ensino de língua portuguesa no Brasil, tanto com relação a sua participação em cursos e projetos ministrados em todo o Brasil quanto pela sua produção escrita, o que indica sua participação e parcerias estabelecidas no país e no exterior.

De acordo com Magnani (1997) e Mortatti (1999; 2000; 2007; 2014), Geraldi destaca-se no cenário brasileiro a partir da década de 1980, do interior do Instituto de Estudos da Linguagem da Universidade Estadual de Campinas, apresentando uma proposta para o ensino de língua portuguesa, a partir do interacionismo linguístico, tomando o texto por objeto de ensino e propondo o trabalho com as três práticas em sala de aula. De forma avassaladora, ele vai desconstruindo certezas, a fim de refletir sobre os problemas que as escolas enfrentavam na época com relação ao ensino de língua portuguesa, estendendo sua atuação também para fora do Brasil.

1 Este texto é resultante de pesquisas de mestrado e de doutorado, desenvolvidas com bolsa CNPq, cujos resultados finais foram apresentados sob a forma de dissertação (Paula, 2004) e de tese (Paula, 2010). Com adequações de redação, a dissertação foi publicada em livro (idem, 2014). [N. O.]. 
Assim, a proposta formulada por Geraldi é pioneira na história do ensino de leitura e escrita no Brasil. Como avalia Mortatti (2000, p.220):

Mesmo não tratando muitas vezes explicitamente da alfabetização e não sendo citadas diretamente nos textos oficiais ou acadêmicos que dela tratam, as tematizações de Geraldi podem ser consideradas emblemáticas em relação ao ensino da língua, nesse âmbito incluindo-se o ensino inicial da leitura e escrita e sua abordagem do ponto de vista do interacionismo linguístico.

Opondo-se à hegemonia do construtivismo em alfabetização, conforme proposto por Emilia Ferreiro, ${ }^{2}$ a proposta de Geraldi também pode ser considerada uma (outra) "revolução conceitual", que se tornou hegemônica no quarto momento (ainda em curso) da história da alfabetização no Brasil (Magnani, 1997; Mortatti, 1999; 2000; 2007; 2014).

\section{Formação e atuação de João Wanderley Geraldi}

João Wanderley Geraldi, ${ }^{3}$ gaúcho nascido no dia 26 de dezembro de 1946, em São Luiz Gonzaga (RS), ficou conhecido, especialmente pelos professores de língua portuguesa, tanto em âmbito nacional quanto internacional, da década de 1980 até os dias atuais, pela sua atuação no ensino de língua portuguesa em nosso país.

2 Informações sobre Emilia Ferreiro encontram-se em texto de Márcia Cristina Oliveira Mello que integra este livro. Estudos sobre essa autora e sua obra foram desenvolvidos por Magnani (1997), Mortatti (2000) e Mello (2007) [N. O.].

3 As informações aqui abordadas foram extraídas de: Geraldi (1995; 1999; 2002; 2004; 2006); dos documentos: Processo no. 2965/72 - Reconhecimento dos cursos de bacharelado em Ciências Sociais, de Economia e de Linguística ministrados pelo IFCH, volumes I e II; Processo n. 7968/76 - Constituição do Instituto de Estudos da Linguagem, e do documento IEL, notas sobre a Unicamp e o IEL, 1982, todos localizados no Arquivo Central do Sistema de Arquivos (Siarq), na Unicamp; e em Cadernos de estudos linguísticos, n.1, publicado em 1978, sob a responsabilidade do Departamento de Linguística do IEL/Unicamp. 
Filho de imigrantes italianos - Laudelino e Maria Geraldi -, agricultores pouco letrados, Geraldi teve por formação inicial, na cidade de Santo Ângelo (RS), o primário, cursado no Grupo Escolar Industrial; três anos do ginásio, cursados no Seminário Apostólico Sagrada Família; um ano no Colégio Santo Ângelo; e o técnico em Contabilidade, na Escola Técnica de Comércio "Sepé Tiaraju".

Profissionalmente, de 1962 a 1965, Geraldi foi office-boy e, de 1966 a 1972, bancário. Concomitantemente à profissão de bancário, no ano de 1966, assumiu a função de professor, como convidado. Inicialmente ministrou aulas nas disciplinas Geografia Geral e Geografia do Brasil, e, no ano seguinte, 1967, de Língua Portuguesa, em uma trajetória iniciada enquanto trabalhava no Banco do Brasil. Isso ocorreu a partir de um convite para ministrar aulas de Geografia no Ginásio Comercial "São Luiz Gonzaga”, mantido pela atual Campanha Nacional de Educandários da Comunidade, em sua cidade natal.

Em nível de Graduação, Geraldi concluiư os cursos de: bacharelado em Ciências Jurídicas e Sociais, cursado na Faculdade de Direito de Santo Ângelo, em Santo Ângelo (RS); e Licenciatura em Letras, primeiramente licenciatura curta $^{5}$, na Faculdade de Filosofia, Ciências e Letras de Santo Ângelo, mantida pela Fundação Missioneira de Ensino Superior (Fundames) ${ }^{6}$, em Santo Ângelo, no ano de 1970. A licenciatura plena em Letras foi cursada em Ijuí (RS), quando era professor do Departamento de Letras na Faculdade de Filosofia, Ciências e Letras de Ijuí, mantida pela Fundação de Integração, Desenvolvimento e Educação do Noroeste do Estado do Rio Grande do Sul (Fidene), em Ijuí.

4 Geraldi iniciou o curso de Economia na Faculdade de Ciências Econômicas e Administrativas em Cruz Alta (RS), sem, no entanto, concluí-lo.

5 Em decorrência da Lei n. 7044, de 18 de Outubro de 1982, "Licenciatura Curta" era a denominação do grau universitário que dava o direito de exercer o magistério no Ensino de 1ํGrau de 5ª a 8a série; e "Licenciatura Plena", o grau universitário que dava o direito de exercer o magistério no Ensino de 2ํ Grau, além do Ensino de 1ํ Grau.

6 Fundames é a entidade mantenedora das faculdades existentes em Santo Ângelo (RS). 
Enfim, em 1972, ele iniciou sua dedicação exclusiva à carreira de professor. O passo seguinte, no ano de 1973, foi a especialização em Linguística, ministrada por professores do Instituto de Estudos da Linguagem (IEL) da Unicamp, no início da década de 1970, no estado do Rio Grande do Sul.

Após esse curso, seus horizontes alargaram-se, e ele deu início à sua trajetória acadêmica no estado de São Paulo: em 1976, iniciou o curso de mestrado em Linguística no IEL/Unicamp; em 1980, o doutorado, fixando, a partir desse ano, residência em Campinas (SP), entre suas idas e vindas atuais ao exterior, principalmente à Alemanha e a Portugal.

Nesses países, Geraldi realizou parcerias com professores de algumas universidades, muitas das quais resultaram em sua participação em eventos e na publicação de textos. Na Universidade de Aveiro, em Portugal, Geraldi ministrou um curso com a duração de seis meses no ano letivo de 2002/2003, conforme calendário letivo de Portugal.

A trajetória do interior do estado do Rio Grande do Sul ao interior do estado de São Paulo rendeu a Geraldi um aprimoramento em sua formação, o que lhe proporcionou inúmeras atuações e consequente comprometimento com o ensino de língua portuguesa.

Geraldi foi chefe do Departamento de Ensino da Fundames, de 1972 a 1974; diretor da Coordenadoria de Pesquisa, Planejamento e Documentação do Museu Antropológico "Diretor Pestana”, em Ijuí (RS), enquanto era professor universitário da Fidene, no período entre setembro de 1978 e março de 1980.

Ele foi presidente da Associação de Leitura do Brasil (ALB), entidade responsável pela publicação do periódico Leitura: teoria \& prática e pela organização dos Congresso de Leitura do Brasil (Cole), com sede em Campinas (SP), no período de 1987 a 1989. Como presidente da ALB, foi o responsável geral pela organização do 7ํㅡㄹ Cole, realizado em 1989 na Unicamp, em Campinas.

Geraldi assessorou secretarias estaduais e municipais de educação do país e participou da elaboração de propostas curriculares e diretrizes para o ensino de língua portuguesa. Junto à Comissão Nacional para Elaboração de Diretrizes para o Ensino e Aprendizagem da 
Língua Portuguesa, no Ministério da Educação, substituiu Magda Soares $^{7}$ e, posteriormente, Aurélio Buarque de Holanda Ferreira. ${ }^{8}$

Além dessas atividades, ministrou inúmeras palestras, cursos e seminários, e participou também de inúmeras conferências e congressos.

Foi professor no Departamento de Letras da Fidene, como já informado, e no IEL. Nesse último instituto, foi orientador de dissertações de mestrado e de teses de doutorado; do IEL, foi também diretor.

De 1980, ano de seu ingresso na Unicamp, até 1995, quando escreveu o memorial para concurso de livre-docência na graduação em Linguística, Geraldi ministrou 28 disciplinas diferentes no IEL, ao longo de 21 semestres letivos. As disciplinas contemplaram os estudos semânticos, a análise do discurso, a variação linguística e as descrições gramaticais do português.

[...] no interior dos estudos semânticos, da análise do discurso, da variação linguística e das descrições gramaticais do português. Nos últimos anos, fui fixando (ou envelhecendo?) minha atuação na área de semântica e de disciplinas optativas, nestas estudando textos de Bakhtin. (Geraldi, 1995, p.32)

Durante um ano, de 27 de abril de 1998 a 5 de abril de 1999, Geraldi atuou como pró-reitor de extensão e assuntos comunitários da Unicamp.

Ele foi representante dos docentes do IEL junto ao Conselho de Representantes da Associação de Docentes da Unicamp (Adu-

7 Magda Becker Soares é professora emérita da Universidade Federal de Minas Gerais (UFMG). Segundo informações que constam em seu currículo, no Sistema de Currículos Lattes, consultado em 9 de dezembro de 2009, ela possui graduação em Letras Neolatinas e doutorado em Didática pela UFMG. Atualmente é membro da Associação Nacional de Pós-Graduação e Pesquisa em Educação e do Comitê Assessor do CNPq. Atua na área de Educação, com ênfase em ensino-aprendizagem.

8 Aurélio Buarque de Holanda Ferreira (1910-1989) nasceu em Passo de Camaragibe (AL) e morreu no Rio de Janeiro $(\mathrm{RJ})$. Atuou como crítico literário, ensaísta, tradutor, filólogo, lexicógrafo e professor. 
nicamp) e também segundo vice-presidente dessa associação, no período de novembro de 1993 a outubro de 1994.

Esse linguista foi o primeiro coordenador do Setor de Publicações do IEL, tendo atuado nessa função por onze anos, na publicação dos periódicos Cadernos de estudos linguísticos e Trabalhos em linguística aplicada. A edição número 24 de Cadernos de estudos linguísticos, em comemoração aos 15 anos de publicação da revista, rendeu homenagens ao seu primeiro coordenador.

O autor desenvolveu, na Unicamp, em 1986, juntamente com outros pesquisadores, projeto a respeito do estado da arte sobre o livro didático, o qual foi financiado pelo Inep. Dessa atividade resultou a publicação Que sabemos sobre livro didático: catálogo analítico.

Sua atuação aconteceu também junto a conselhos editoriais de inúmeros periódicos, nos quais ainda atua: Cadernos de estudos linguísticos, editado pelo Departamento de Linguística do IEL/ Unicamp (Campinas-SP); Leitura: teoria É prática, editada pela ALB e pela Editora Mercado Aberto (Porto Alegre-RS); Revista da FAEEBA, editada pela Faculdade de Educação da Universidade do Estado da Bahia; e Educação e Realidade, editada pela Faculdade de Educação da Universidade Federal do Rio Grande do Sul (Porto Alegre-RS); Filologia e linguística portuguesa, da Universidade de São Paulo (USP) (São Paulo-SP); Educação E contemporaneidade, da Universidade do Estado da Bahia (Uneb) (Salvador-BA); Signo, da Universidade de Santa Cruz do Sul (Unisc) (Santa Cruz do Sul-RS); Letras, da Pontifícia Universidade Católica de Campinas (PUC-Campinas) (Campinas-SP); Espaço pedagógico, da Universidade de Passo Fundo (UPF) (Passo Fundo-RS); Cadernos Camilliani, do Centro Universitário São Camilo (Cusc) (Cachoeiro de Itapemirim-ES); e um periódico português, Palavras, da Associação de Professores de Português (APP) (Portugal).

Atuou, ainda, na elaboração de planos curriculares em vários estados brasileiros, entre outras atividades.

Em novembro de 2002, Geraldi foi promovido a professor titular do IEL/Unicamp, e, quase um ano depois, em outubro de 2003, aposentou-se. 
Por ocasião das comemorações dos vinte anos da Fundames, em 26 de novembro de 1983, Geraldi recebeu o título de "Colaborador Benemérito" dessa instituição, pelos serviços prestados quando da transformação dessa instituição em universidade. Por ocasião do 15 Cole, realizado na Unicamp em julho de 2005, recebeu a homenagem de amigos, professores de todo o país e estrangeiros, assim como de seus colegas, professores da Unicamp e ex-orientandos pelos vinte anos de publicação da coletânea $O$ texto na sala de aula, momento em que foi ressaltado o sucesso de suas várias edições, de 1984 até aquela data. Na realização do $16^{\circ}$ Cole, na Unicamp em julho de 2007, foi agraciado com o título de "Presidente de Honra" da ALB.

Atualmente, atua no IEL/Unicamp como professor colaborador voluntário; é membro do corpo editorial de vários periódicos; como professor visitante, participa de programas de pós-graduação em Educação na Universidade do Porto e na Universidade de Aveiro, em Portugal; como professor e pesquisador associado do Programa Internacional de Doutorado em Educação (Inedd), na Universidade de Siegen, na Alemanha, colabora atualmente na orientação de doutorandos brasileiros.

Quanto à produção científica, Geraldi continua dedicando-se em especial ao estudo e à produção de textos sobre Mikhail Bakhtin, ${ }^{9}$ Paulo Freire ${ }^{10}$ e Lev Vigotski, ${ }^{11}$ discorrendo sobre ques-

9 O pensador Mikhail Mikhailovich Bakhtin (1895-1975), conhecido por seus estudos sobre a filosofia da linguagem, nasceu em Orel, Rússia, ao sul de Moscou. Estudou Filosofia e Letras na Universidade de São Petersburgo. No Brasil, ficou conhecido a partir da década de 1980, inicialmente na área da Literatura (Bakhtin, 1992).

10 Paulo Freire (1921-1997) nasceu em Recife (PE) e faleceu em São Paulo (SP). Foi um grande educador brasileiro, que esteve sempre comprometido com a educação popular, tendo ficado conhecido internacionalmente. Por esse motivo, no momento da Ditadura Militar brasileira, foi exilado. Após o exílio, de volta ao Brasil, Paulo Freire destacou-se por sua atuação junto à Prefeitura de São Paulo, de 1989 a 1991, quando foi secretário de Educação. Na Unicamp, foi professor titular da FE/Unicamp durante onze anos, de 1980 a 1991.

11 Lev Vigotski (1896-1934) nasceu em Orsha, Bielorússia e morreu na Rússia, ainda jovem. Ficou conhecido por seu pensamento sobre o desenvolvimento do sujeito a partir do meio em que ele vive. 
tões políticas, filosóficas, éticas, educacionais e científicas, e unindo ideias advindas de outras áreas, como da Ciência, da Arte, da Educação e da Filosofia, a seu pensamento sobre linguagem.

Enfim, o linguista Geraldi participa ativamente da discussão sobre os problemas do ensino de língua portuguesa no Brasil, com a formulação de uma proposta que qualifico, sobretudo, como apaixonada, pois, assim como a "serpente seduz e abocanha o batráquio", em "O cururu”, do poeta alagoano Jorge de Lima (1994), também Geraldi é exímio autor, capaz de seduzir o leitor dos textos sobre o ensino de língua portuguesa com uma linguagem, mais do que tudo, envolvente. Seus textos revelam esse "olhar para o outro" e o desejo de caminhar junto, como se refere o poeta Carlos Drummond de Andrade (2001).

\section{O professor/linguista João Wanderley Geraldi}

A docência foi mais que um desafio para Geraldi, e sua contribuição para o ensino de língua portuguesa aconteceu tanto pelos cursos e projetos de formação de professores em todo o Brasil, conhecidos como "projeto do Wanderley", quanto pela sua produção escrita, iniciada no final da década de 1970 (Magnani, 1992; Mortatti, 1999; 2000; 2014; Silva, 1997)

Naquele momento, havia uma preocupação geral com novas ideias em relação às existentes, baseadas em um "ensino tradicional". Nesse âmbito, novas propostas em relação a esse ensino emergiam, especialmente no interior do IEL. Era um momento de acirrados embates entre as diferentes concepções linguísticas, em parte movidas pela própria constituição do IEL, e também de busca de soluções para os problemas da educação em geral e, sobretudo, para o do ensino de língua portuguesa.

Membros da Coordenadora de Estudos e Normas Pedagógicas convidaram professores universitários do IEL/Unicamp para escreverem textos a fim de que participassem da publicação dos Guias 
Curriculares. ${ }^{12}$ Eles buscavam respostas para os problemas da educação, entre os quais havia a preocupação com a questão da alfabetização, pois os alunos não saíam alfabetizados da escola. Além disso, havia também os problemas de evasão e de repetência, em razão dos quais estavam sendo questionados os órgãos governamentais.

A partir de sua atuação, Geraldi respondia, ao mesmo tempo, às próprias indagações e também às da sociedade da época sobre o ensino de língua portuguesa quanto aos problemas relativos à falta de professores bem formados para atuar na área, entre outros aspectos. Para essas questões, ele buscou resposta nas concepções linguísticas, "deslocando-as" para esse ensino. Para ele, faltava aos professores o conhecimento teórico sobre linguística para que as práticas em sala de aula pautassem-se em teorias, além da importância de o sujeito ser reconhecido como produtor de seus textos.

Ao longo de 35 anos, Geraldi produziu 234 textos. Essa sua produção escrita ocorreu do ano de 1978, quando foram publicados seus primeiros textos, até o ano de 2012, determinado para o encerramento da localização dos documentos para a pesquisa que resultou neste artigo.

Essas referências distribuem-se em: livros (como autor, organizador ou coordenador e coautor), quinze; capítulos de livros (como autor e coautor), 38; artigos em periódicos (como autor e coautor), 65; entrevistas (como autor e coautor), 24; textos em anais de eventos (como autor e coautor), 22; artigos em jornais (como autor e coautor), quatro; resenhas, nove; prefácios e apresentações de livros, 23; quarta capa e orelhas de livros, seis; traduções, doze; periódico, um; dissertação, teses e memoriais acadêmicos, seis; e vídeos, nove.

Mesmo exercendo atividades administrativas e atuando intensamente em cursos e assessorias, no período de 1978 a 2013, Geraldi teve publicações em quase todos os anos, exceto em 1979, ano em que esteve em Ijuí, desenvolvendo atividades docentes no Departamento de Letras da Fidene e atuando como diretor da Coordenadoria de Planejamento e Pesquisa dessa instituição.

12 Os "Guias Curriculares", resultantes/propostos pela Lei n. 5692/71, tinham por objetivo auxiliar o professor e também garantir a introdução da lei. 
Em 1978, teve início a produção escrita de Geraldi, com os seguintes textos: um artigo publicado em Série estudos (Uberaba-MG) - "Algumas observações sobre o estudo da significação"; o texto publicado em anais do Grupo de Estudos Linguísticos (GEL), número 1, realizado em Mogi das Cruzes (SP), intitulado "Orientação argumentativa e pressuposição", em coautoria com Celene Margarida Cruz; e a dissertação de mestrado em Linguística, defendida no IEL/Unicamp, intitulada Se a semântica fosse também pragmática... ou para uma análise semântica dos enunciados condicionais, a qual não foi publicada. Esses textos estão embasados na Semântica Argumentativa, linha de pesquisa do Departamento de Linguística do IEL/Unicamp, e fundamentam-se em reflexões de Carlos Vogt, orientador de Geraldi no mestrado.

Um maior número de textos de Geraldi foi publicado como artigo em periódico, resultando em 65 artigos publicados em 45 diferentes periódicos de vários estados do Brasil e também de Portugal, todos abrangendo questões relativas às áreas de Letras, Linguística e Educação.

Esses periódicos circulam nas grandes universidades brasileiras e também nas universidades de Portugal, tendo por interlocutores alunos de graduação e de pós-graduação. Inicialmente os artigos de Geraldi eram divulgados apenas em periódicos brasileiros. No entanto, a partir de 2002, iniciou-se uma divulgação de seu pensamento também junto a outros países, dada sua atuação em Portugal e na Alemanha, como anteriormente mencionado.

Considerando as condições de circulação desses periódicos em várias universidades, é possível inferir que o interlocutor pretendido por na maioria de seus textos é o professor em formação (alunos de graduação e de pós-graduação), com quem estabeleceu e ainda estabelece embates teóricos.

O segundo maior número desse autor foi publicado sob a forma de capítulos de livro. Dentre os 31 capítulos de livros, três estão presentes em livros de um mesmo organizador: Adriano Nogueira. Os outros 28 integram livros de diferentes organizadores. Dentre os 31 capítulos de livros, 29 foram publicados como autor, e dois como coautor. 
Com relação aos livros publicados de Geraldi, de um total de nove, como autor, organizador, coordenador e coautor, apenas dois são publicados por uma mesma editora, a Ática. Os outros sete foram publicados por diferentes editoras.

Observa-se, por meio da intensa produção escrita de Geraldi, a atuação de um autor que reflete sobre o ensino de língua portuguesa e sobre sua prática, atualizando, publicando e fazendo veicular suas ideias em diferentes estados e diversos meios de comunicação. As assessorias de Geraldi a diversas instituições de ensino também se fazem visíveis nesses diversos tipos de textos por ele escritos e que foram publicados.

Com relação ao número de textos, sua publicação ocorreu em uma escala progressiva do final da década de 1970 até a década atual, tendo em vista o momento histórico e as solicitações da sociedade da época para que os pesquisadores publicassem os resultados de suas pesquisas conforme a política acadêmica do momento.

A ocorrência de um menor número de textos publicados nas primeiras décadas de atuação de Geraldi explica-se, em parte, pela divulgação de sua proposta para o ensino de língua portuguesa naquele momento, e também por sua atuação em projetos sobre o ensino.

No final da década de 1970, Geraldi iniciou o mestrado na Unicamp e também suas publicações; na década de 1980, ocorreu uma intensa divulgação de sua proposta em todo o país; na década de 1990, estavam sendo publicados, pelo Ministério da Educação, tanto a Lei de Diretrizes e Bases da Educação Nacional (1996) quanto os Parâmetros Curriculares Nacionais: língua portuguesa (1997), momento em que foram oficializadas algumas concepções vinculadas a propostas para o ensino da língua portuguesa, entre elas, a de Geraldi. ${ }^{13}$

13 Nos Parâmetros Curriculares Nacionais: língua portuguesa são citados dois livros de sua autoria: $O$ texto na sala de aula e Portos de passagem, e um livro em coautoria com Lígia Chiappini: Aprender e ensinar com textos dos alunos. Além disso, há a seguinte nota de rodapé com menção a Geraldi: "Os termos 'análise linguística', 'atividade epilinguística' e 'atividade metalinguística' são utilizados aqui como propostos por João Wanderley Geraldi, no livro Portos de passagem” (p.38). 
O autor também teve livros publicados por editoras brasileiras e estrangeiras, o que indica a circulação e expansão de seu pensamento em outros países. É possível considerar que os livros de Geraldi foram publicados por editoras de representatividade tanto no mercado editorial brasileiro quanto no mercado editorial de dois outros países: Chile e Portugal. A única exceção refere-se ao livro $O$ texto na sala de aula: leitura \& produção (1984), publicado pela Assoeste (PR), uma editora do oeste do estado do Paraná que, por ser uma editora regional, não conseguiu atender à demanda da coletânea, a qual, por esse motivo, a partir de 1997, passou a ser editada pela Ática.

Comparativamente, a Ática é a editora brasileira com maior publicação de livros de Geraldi, tendo sido publicados por ela três deles. Essa editora assumiu, no final da década de 1990, a publicação da coletânea $O$ texto na sala de aula (1997; 2005), e anteriormente já havia publicado o livro Semântica (1985).

Esse conjunto de aspectos referentes às instituições responsáveis pelos periódicos em que foram publicados seus artigos, as editoras que publicaram seus livros e os diferentes organizadores dos livros em que foram publicados seus capítulos, entre outros, é indicativo de que a publicação dos textos de Geraldi por diferentes editoras e instituições foi um dos quesitos responsáveis pelo conhecimento e reconhecimento de seu pensamento em território brasileiro, da década de 1980 até os dias atuais.

Entre outros aspectos, deve-se observar que, ao longo desses 35 anos, Geraldi produziu textos não apenas individualmente, mas foi estabelecendo parcerias, atuando como coordenador, organizador e coautor de textos com autores que, de ponto de vista semelhante ao dele, tematizam o ensino de língua portuguesa no Brasil.

Do total de textos publicados por Geraldi, 39 deles foram elaborados em coautoria (como organizador, coordenador e como coautor), distribuídos em oito tipos: livros, capítulos de livro, artigos em periódico, entrevistas, textos em anais, artigos em jornais de notícias, resenhas e traduções, das quais participaram 42 coautores. 
A maior parte dos coautores de textos com Geraldi é composta, principalmente, por professores/pesquisadores da Unicamp. ${ }^{14} \mathrm{Em}$ segundo lugar, em número de parcerias, estão os professores vinculados à USP ${ }^{15}$ e às demais universidades brasileiras. ${ }^{16}$

As parcerias foram estabelecidas também com coautores estrangeiros. Dentre eles, destacam-se os vinculados à Universidade de Aveiro (Portugal), ${ }^{17}$ à Universidade de Siegen (Alemanha), ${ }^{18}$ ao

14 Ao todo são 21 professores/pesquisadores: quatorze vinculados ao IEL Celene Margarida Cruz, Conceição Aparecida de Jesus, Eduardo Guimarães, Eliana Maria Severino Donaio Ruiz, Haquira Osakabe, Jesus Antonio Durigan, Jonas de Araújo Romualdo, Liliane Moreira, Maria Bernadete Abaurre, Maria Filomena Spatti Sândalo, Maria Laura Mayrink-Sabinson, Raquel Salek Fiad, Rodolfo Ilari, Sírio Possenti; cinco vinculados à Faculdade de Educação - Afira Vianna Ripper, Corinta Maria Grisólia Geraldi, Joseane Zaghetti, Lilian Lopes Martin da Silva e Sarita Aparecida Affonso Moysés; um vinculado ao Núcleo Interdisciplinar para a Melhoria do Ensino de Ciências (Nimec) - Adriano Nogueira; e uma vinculada à Faculdade de Ciências Médicas (FCM)/Unicamp - Maria Aparecida Affonso Moysés.

15 Esses professores/pesquisadores são: seis vinculados à Faculdade de Filosofia, Letras e Ciências Humanas (FFLCH) - Beatriz Helena Marão Citelli, Claudinéia Barbosa de Azevedo, Elisa Duarte Teixeira, Lígia Chiappini, Maria Madalena Iwamoto Sercundes, Marlete Carboni Tardelli; um vinculado à Escola de Comunicação e Artes (ECA) - Adilson Citelli; e uma vinculada à Universidade Cruzeiro do Sul/USP - Guaraciaba Micheletti.

16 Quanto aos demais professores/pesquisadores brasileiros, coautores de textos com Geraldi, destacam-se: vinculada à Unifran (SP), Cecília Azevedo Lima Collares; vinculado à Uninove (SP) e ao Instituto Paulo Freire (SP), José Eustáquio Romão; vinculada à UFS (SE), Maria Nilma Góes da Fonseca; vinculada ao Instituto de Filosofia e Ciências Humanas (UFRGS), Carla Mauch; vinculado à Unemat, Carlos Maldonado; Lurdi Haas, vinculada à Escola "Rita Caldas" da Secretaria Municipal de Cuiabá; e Alessandra Vidotti, Eunice Cesnik, Maria Florentina Camerini e Sandra Leibovici, vinculadas ao Instituto Vigotski.

17 Os professores/pesquisadores vinculados à Faculdade de Aveiro são: Abreu Freire, Ana Isabel Andrade, António Moreira, Cristina Manuela Sá, Isabel Alarcão, Luísa Álvares Pereira, Manuel Bernardo Canha, Maria Helena Ançã, Maria Helena Araújo e Sá, Mario Gamito, Susana Pinto e Teresa Cardoso.

18 Os professores vinculados à Faculdade de Siegen (Alemanha) são: Bernd Fichtner, Amauri Lobo, Clemens Knobloch e Maria Benites, também vinculada à Universidade de Siegen (Alemanha) e ao Instituto Vigotski. 
Instituto Vigotski (SP); ${ }^{19}$ à Faculdade de Psicologia e de Ciências da Educação da Universidade do Porto (FPCEUP-Portugal); ${ }^{20}$ e à Universidade de Barcelona (Espanha). ${ }^{21}$

As parcerias com diversos professores/pesquisadores, as quais resultaram na publicação de textos, além da materialização das ideias afins sobre as quais se podia refletir e veicular naquele momento, permitem também a compreensão dos vários embates que antecederam a publicação de cada texto, assim como das relações de coautoria: coautores que vêm e vão; coautores de textos publicados em um determinado momento; coautores de um único texto; coautores em âmbito nacional e internacional; vários aspectos advindos das ciências linguísticas e debatidos no momento e ao mesmo tempo; parcerias com ex-professores e colegas de trabalho; coautores ligados a tema de mesmo interesse.

Destacam-se, em número de ocorrência, os oito textos publicados em coautoria com Raquel Salek Fiad, os quais abordam o ensino de língua portuguesa: $O$ ensino de língua portuguesa no $1^{\circ}$ grau: projeto magistério (1986), "O livro didático de língua portuguesa: didatização e destruição da atividade linguística” (1986), "A destruidora didática dos livros" (1986), "Para repensar o ensino de português" (1989), "A sala de aula é uma oficina de dizer coisas" (1994), "Considerações sobre a utilização de um paradigma indiciário na análise de episódios de refacção textual” (1995), "O caráter singular das operações de refacção nos textos representati-

19 Maria Benites está vinculada à Universidade de Siegen (Alemanha) e ao Instituto Vigotski.

20 Esses professores/pesquisadores estão vinculados ao FPCEUP (Portugal): Luiza Cortesão, Rosa Nunes e Rui Trindade.

21 Vinculados à Faculdade de Barcelona (Espanha) estão os professores/pesquisadores: Fernando González e Jorge Larrosa. E, especialmente para a entrevista "Leitura e escrita na escola podem ser livres?" (2005), as parcerias aconteceram também com as crianças: Miréia Larrosa, filha de Jorge Larrosa, professor espanhol; e Tomás González e Vera González, filhos de Fernando González, sociólogo espanhol, e Victória Carbó, professora de música em Barcelona (Espanha). 
vos do início da aquisição da escrita" (1995) e "Linguística, ensino de língua materna e formação de professores” (1996).

No entanto, é preciso considerar também as parcerias que são menos explícitas: as constituídas para inúmeras palestras, eventos e cursos de longa e de curta duração, assim como os convites e as conversas de corredores de que Geraldi participou, parcerias estas que não foram publicadas, mas auxiliaram e motivaram as reflexões suscitadas e propostas no percurso de seu pensamento sobre o ensino de língua portuguesa.

Essas reflexões e embates com professores, orientandos, colegas e amigos foram sendo estabelecidas com a geração com a qual Geraldi dialogou/dialoga, primeiramente para a execução de projetos, assim como para a apresentação em eventos, cujos resultados foram registrados em seus textos.

Essas parcerias com diferentes professores/pesquisadores indicam o movimento de seu trabalho nos momentos que antecederam a publicação e naqueles em que ela ocorreu. Seus textos materializam as diversas ações estabelecidas com esses professores/pesquisadores, as quais refletem, entre outras, prioritariamente sobre a linguagem e seu ensino.

Com relação à temática de seus textos, sobressaem, em número, as tematizações sobre "o ensino de língua portuguesa", incluindo a fase inicial desse ensino, a alfabetização (Mortatti, 1999; 2014). No entanto, Geraldi também elaborou textos sobre "análises descritivas da linguagem", "importantes pensadores para a educação brasileira", 22 "educação em geral", "questões científicas e "traduções de textos sobre teorias vigentes no Brasil".

22 Na produção de Geraldi estão inclusos textos sobre a atuação dos brasileiros Paulo Freire, Antonio Candido e Carlos Franchi, e sobre os estrangeiros Mikhail Bakhtin, Lev Vigotski e Gregory Bateson. Os trabalhos de Lev Vigotski e Gregory Bateson foram tematizados recentemente no livro Transgressões convergentes: Vigotski, Bakhtin, Bateson (2006), de Geraldi em coautoria com Bernd Fichtner e Maria Benites, publicado pela editora Mercado de Letras. 
Com relação às reflexões de Geraldi sobre o ensino de língua portuguesa, no início da década de 1980, no momento em que ele começou a ministrar aulas dessa disciplina em sua cidade natal, São Luiz Gonzaga (RS), nasceu seu interesse em cursar a licenciatura curta em Letras, a licenciatura plena, a especialização em Linguística e os cursos de mestrado e doutorado no IEL/Unicamp, como mencionado anteriormente. A partir desses cursos foi possível para ele conhecer diferentes concepções teóricas na área da Linguística, travando com elas muitos embates, que resultaram em uma proposta pioneira para o ensino de língua portuguesa no Brasil.

Sobre essa proposta, em "Subsídios metodológicos para o ensino de língua portuguesa: 5a a $8^{\mathrm{a}}$ séries" (1981) encontram-se suas primeiras tematizações. Nesse periódico foram publicados dois artigos: "Ensino da língua ou ensino da metalinguagem?" e "Unidades básicas do ensino de língua portuguesa”.

Esses dois artigos, outros dois de sua autoria e mais um em coautoria com Maria Nilma Goes da Fonseca ${ }^{23}$ foram publicados na coletânea $O$ texto na sala de aula: leitura $\mathcal{E}$ produção, em 1984, pela Assoeste, visando à utilização desses textos no curso de formação de professores que Geraldi ministrou com outros professores que participaram do curso e de outros que tiveram seus textos publicados na coletânea. A partir da publicação dessa coletânea, objeto de estudo de minha dissertação de mestrado (Paula, 2004a), a atuação de Geraldi no ensino de língua portuguesa foi sendo gradualmente cada vez mais representativa.

As reflexões sobre as concepções teóricas contidas na coletânea tiveram continuidade nas reflexões de seu organizador, especialmente em outros dois de seus livros, publicados posteriormente: Portos de passagem (1991), resultante da tese de doutorado, e Linguagem e ensino: exercícios de militância e divulgação (1996), resultante de sua tese de livre-docência. Além desses textos, em que

23 No momento de publicação da coletânea $O$ texto na sala de aula, Maria Nilma Goes da Fonseca era professora da Secretaria de Educação de Sergipe. Atualmente é professora da Universidade Federal de Sergipe (UFS). 
considero estar publicada a matriz de seu pensamento, em outros textos seus também foram contempladas questões singulares sobre sua proposta para o ensino de língua portuguesa.

O ensino de língua portuguesa proposto por Geraldi estava organizado da seguinte maneira: baseado em práticas, e não em conteúdos, propunha o ensino gramatical após o domínio da linguagem, além de revelar a existência de aspectos ainda não presentes no ensino de língua portuguesa - a concepção interacionista, a noção de texto, a variedade linguística e a organização do ensino em torno de "práticas". (Geraldi; Silva; Fiad, 1996).

Dessa forma, apoiando-se na interlocução como principal processo de trabalho em sala de aula, Geraldi contribuiu para o ensino de língua portuguesa, refletindo sobre o fato de a aula ser construída no interior mesmo da sala de aula, no momento em que os alunos são considerados sujeitos de seu conhecimento. Dessa forma, é na sala de aula que deve acontecer o diálogo entre os sujeitos que participam dessa interação e que provocam o "movimento linguístico", que caracteriza, por sua vez, o interacionismo.

Abordando a interação dos sujeitos, Geraldi propõe o trabalho com o texto como unidade e objeto de ensino. Para ele, a prática anterior de ensino de língua portuguesa, que privilegiava o ensino da gramática normativa, não permitia que o aluno se constituísse como sujeito e dono de seu pensar. E, sob essa perspectiva, ele critica o trabalho sem a participação do aluno que ocorre em sala de aula, pois, para ele, o conhecimento é construído na interlocução com o sujeito, a partir da reflexão.

A partir dessas concepções de Geraldi, o texto passou a ser tomado como objeto de ensino, e o trabalho do professor em sala de aula começou a exigir deste um conhecimento pautado nas concepções de linguagem e de sujeito.

Abordando o texto como objeto de ensino, Geraldi propôs três práticas para o trabalho com o texto: leitura, produção e análise linguística. Dessas práticas, a central, para ele, é a produção de textos, complementada pelas atividades de leitura e de análise linguística. Isso porque, segundo o autor, a atividade de produção constitui-se 
como elemento essencial, tanto para a linguagem quanto para o sujeito, e como condição de reflexão sobre o ensino de língua portuguesa. O trabalho com o texto em sala de aula, segundo Geraldi, contrapõe-se tanto à atividade de gramática normativa como atividade meramente descritiva quanto à utilização do livro didático em sala de aula, que, segundo ele, assujeita o trabalho do aluno.

Sob essa perspectiva, Geraldi considera que o trabalho do professor deve estar pautado no ensino e na aprendizagem do texto do aluno, priorizando a reflexão sobre a linguagem. Esse modo de pensar o ensino advém da constatação de que os textos produzidos pelos alunos anteriormente indicavam que a prática de redação não lhes permitia a reflexão necessária para a produção de bons textos. Nesse sentido, ocorreu uma ressignificação em sala de aula, tanto do objeto de ensino quanto das atividades praticadas com esse objeto.

Quanto à linguagem e sua constituição, para Geraldi (1991b, p.20, destaques no original), "Trata-se de pensar a atividade linguística não só a partir das ações que se fazem com a linguagem, mas de pensá-la também a partir das ações que se fazem sobre a linguagem e das ações da linguagem”. Assim, segundo ele, "[...] estes três tipos de ações se entrecruzam e se concretizam nos recursos expressivos que, materialmente, as revelam. [...] a linguagem permite tais ações em função de uma de suas características essenciais: a reflexividade [...]" (ibidem, p.24).

Esse percurso de Geraldi, nos quatro cantos do Brasil e também no exterior, revela uma proposta que "desestabilizou certezas", e por conta disso explicam-se as parcerias, os convites ainda no momento atual para tratar de questões da mesma natureza. Constata-se que, por todos esses movimentos, o trabalho de Geraldi sobre o ensino de língua portuguesa ganhou reconhecimento, tanto em âmbito nacional quanto internacional, quando ofereceu como opção, de forma pioneira, uma nova proposta para o ensino de língua portuguesa a partir do interacionismo linguístico, especialmente considerando o texto como objeto de ensino. 


\section{Considerações finais}

João Wanderley Geraldi integra, sobretudo, um grupo de pesquisadores unicampianos que na década de 1980 articulava questões que se faziam imprescindíveis ao ensino. Do interior do IEL, onde ele se formou e atuou, as concepções que embasaram seu pensamento foram de natureza linguística. No entanto, essas parcerias não ficaram restritas ao seu meio imediato, pois se estenderam tanto a faculdades unicampianas, principalmente a Faculdade de Educação, quanto a outros professores/pesquisadores das universidades de todo o Brasil, com destaque para a USP, onde Geraldi também foi convidado a atuar, constituindo parcerias com diferentes professores/pesquisadores.

Esse pioneirismo de Geraldi no ensino de língua portuguesa atendia a uma necessidade social e política da sociedade da época com relação à melhoria da qualidade de ensino, para o que deveria contribuir a aplicação das novas ideias linguísticas no ensino de língua portuguesa das escolas brasileiras, especialmente o interacionismo linguístico. Isso tudo ocorria coerentemente com um processo de redemocratização do país, em que a linguagem deveria contribuir para construir a consciência política a ser estabelecida.

Dessa forma, Geraldi, com a coletânea $O$ texto na sala de aula, veiculou nas escolas brasileiras uma proposta para o ensino de língua portuguesa mediante o trabalho com o texto a partir das três práticas: leitura, produção e análise linguística. Esse trabalho foi veiculado desde 1984 por essa coletânea e pela atuação de Geraldi e dos professores que com ele participavam da divulgação dessas ideias, desenvolvendo atividades no âmbito do que ficou conhecido como "projeto do Wanderley". A Linguística "chega", então, ao Brasil, propiciando a formulação de propostas de mudanças para o ensino de língua portuguesa.

Considera-se que o eixo norteador da atuação de Geraldi está presente na coletânea $O$ texto na sala de aula e teve continuidade nos dois livros publicados em sequência: Portos de passagem e Linguagem e ensino: exercícios de militância e divulgação. 
No clima daquele momento, a preocupação de Geraldi era a de que o ensino de língua portuguesa pudesse ser modificado, e era necessário intervir para que esse ensino tomasse novas dimensões.

Em síntese, a proposta para o ensino de língua portuguesa veiculada por Geraldi e outros participantes desse "projeto do Wanderley" soava como um alerta sobre o poder da linguagem, demonstrando que sua aprendizagem acontece por meio de práticas, sendo capaz de influenciar as relações humanas, cabendo à escola disponibilizá-la ao aluno.

É nesse sentido que representou, conforme Magnani (1997) e Mortatti (1999; 2000; 2014) outra "revolução conceitual", que se sedimentou (embora nem sempre explicitamente, como a de Emilia Ferreiro) neste quarto momento da história da alfabetização no Brasil.

\section{Referências bibliográficas}

BAKHTIN, M. Marxismo e filosofia da linguagem. Tradução de Michel Lahud e Yara Frateschi Vieira. 6.ed. São Paulo: Hucitec, 1992.

FREIRE, P. A importância do ato de ler: em três artigos que se completam. 45.ed. São Paulo: Cortez, 2003.

GERALDI, J. W. Subsídios metodológicos para o ensino de língua portuguesa: 5a a 8éries. Cadernos FIDENE, Ijuí, n.18, p.70, 1981. . (org.). O texto na sala de aula: leitura \& produção. Cascavel: Assoeste, 1984. . Portos de passagem. São Paulo: Martins Fontes, 1991a.

. Linguagem e ação. In: SCOZ, B. J. L. et al. Psicopedagogia: contextualização, formação e atuação profissional. Porto Alegre: Artes Médicas, 1991b, p.19-25.

Memorial: 1946-1994. Campinas, 1995. 58f. Memorial (Concurso de Livre-Docência) - Instituto de Estudos da Linguagem, Universidade Estadual de Campinas. Não publicado.

Linguagem e ensino: exercícios de militância e divulgação. Campinas: ALB; Mercado de Letras, 1996. . (org.). O texto na sala de aula. São Paulo: Ática, 1997. 
Memorial: janeiro de 1995 a abril de 1999. Campinas, 1999. 23f. Memorial (Promoção a professor adjunto por avaliação de mérito) Instituto de Estudos da Linguagem, Universidade Estadual de Campinas. Não publicado.

Memorial: maio de 1999 a abril de 2002. Campinas, 2002. 34f. Memorial (Promoção a professor titular por avaliação de mérito) - Instituto de Estudos da Linguagem, Universidade Estadual de Campinas. Não publicado.

; SILVA, L. L. M da; FIAD, R. S. Linguística, ensino de língua materna e formação de professores. D.E.L.T.A, São Paulo, v.12, n.2, p.307-26, 1996.

IEL. Notas sobre a Unicamp e o IEL, 1982.

MELLO, M. C. de O. Emilia Ferreiro e a alfabetização no Brasil: um estudo sobre a Psicogênese da língua escrita. São Paulo: Editora Unesp, 2007. v.1.128p.

MAGNANI, M. do R. M. Os sentidos da alfabetização: a "questão dos métodos" e a constituição de um objeto de estudo (São Paulo: 1876/1994). Presidente Prudente, 1997. 389f. Tese (Livre-Docência

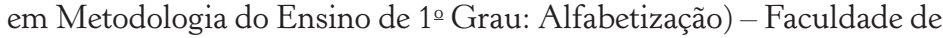
Ciência e Tecnologia, Universidade Estadual Paulista.

MORTATTI, M. do R. M. Notas sobre linguagem, texto e pesquisa histórica em educação. História da Educação, Pelotas, v.6, p.69-77, out. 1999.

MORTATTI, M. do R. L. Uma proposta para o próximo milênio: o pensamento interacionista sobre alfabetização. Presençapedagógica, Belo Horizonte, v. 5, n. 29, p.21-27, set./out.1999.

Os sentidos da alfabetização: São Paulo 1876/1994. São Paulo: Editora Unesp, 2000.

O texto na sala de aula: uma revolução conceitual na história do ensino de língua e literatura no Brasil. In: SILVA, L. L. M.; FERREIRA, N. S. A.; MORTATTI, M. R. L. (Orgs.). O texto na sala de aula: um clássico sobre ensino de língua portuguesa. Campinas: Autores Associados, 2014.

PAULA, L. de F. O ensino de língua portuguesa no Brasil, segundo João Wanderley Geraldi. São Paulo: Editora Unesp, 2014.

Processo no 2965/72 - Reconhecimento dos cursos de bacharelado de Ciências Sociais, de Economia e de Linguística ministrados pelo IFCH, volume I, 1972.

Processo no 2965/72 - Reconhecimento dos cursos de bacharelado de Ciências Sociais, de Economia e de Linguística ministrados pelo IFCH, volume II, 1972. 
Processo $n^{0}$ 7968/76 - Constituição do Instituto de Estudos da Linguagem, 1976.

VIGOTSKI, L. S. Pensamento e linguagem. Tradução de Jéferson Luiz Camargo. São Paulo: Martins Fontes, 1994. 


\section{SOBRE OS AUTORES}

Maria do Rosário Longo Mortatti. Professora titular da FFC-Unesp, campus de Marília. Atua no curso de Pedagogia e no Programa de Pós-Graduação em Educação. É coordenadora do Grupo de Pesquisa "História do Ensino de Língua e Literatura no Brasil” (GPHELLB). É licenciada em Letras pela Faculdade de Filosofia, Ciências e Letras de Araraquara (1975); mestre em Educação pela Faculdade de Educação da Universidade Estadual de Campinas (FE-Unicamp) (1989); doutora em Educação pela FE-Unicamp (1991); livre-docente em Metodologia do ensino de 1 Grau: alfabetização, pela Unesp, campus de Presidente Prudente (1997). Associada-fundadora e presidente (2012-2014) da ABAlf - Associação Brasileira de Alfabetização.

Estela Natalina Mantovani Bertoletti. Professora da Universidade Estadual do Mato Grosso do Sul, campus de Paranaíba. Atua no curso de Pedagogia e no Programa de Pós-Graduação em Educação. Coordena o grupo de pesquisa "História e Historiografia da Educação Brasileira” (Uems). Licenciada em Letras pela Universidade Federal do Mato Grosso do Sul, campus de Três Lagoas (1990); mestre em Educação (1997) e doutora em Educação (2006) pela Unesp, campus de Marília. Realizou estágio de pós-doutorado na Faculdade de Ciências e Letras 
da Unesp, campus de Araraquara, e realiza estágio de pós-doutorado na Faculdade de Educação da Universidade do Estado do Rio de Janeiro (Uerj). Representante regional (suplente) Centro-Oeste (2012-2014) e vice-tesoureira (2014-2016) da Associação Brasileira de Alfabetização (ABAlf).

Márcia Cristina de Oliveira Mello. Professora da Unesp, campus de Ourinhos. Atua no curso de Geografia. É licenciada em Pedagogia pela Faculdade Estadual de Filosofia, Ciência e Letras de Jacarezinho (PR) (1995); mestre em Educação (2003) e doutora em Educação (2007) pela Unesp, campus de Marília. Membro titular do Conselho Fiscal (2014-2016) da Associação Brasileira de Alfabetização (ABAlf).

Thabatha Aline Trevisan. Atuou como professora do curso de Pedagogia da Unesp, campus de Marília. Licenciada em Pedagogia (2003), pela FFC-Unesp-Marília; mestre em Educação (2007) e doutora em Educação (2011) pela Unesp, campus de Marília, com estágio sanduíche na Université René Descartes (Paris 5-Sorbonne); pós-doutoranda junto à Unesp, campus de Marília. Membro titular do Conselho Fiscal (2012-2014) e Secretária (2014-2016) da Associação Brasileira de Alfabetização (ABAlf).

Fernando Rodrigues de Oliveira. Professor da Faculdade de Ciências Contábeis e Administração de Tupã (Faccat), onde atua nos cursos de Pedagogia, Comunicação Social (Jornalismo e Publicidade e Propaganda) e Administração. É licenciado em Letras pela Faculdade da Alta Paulista (2006); licenciado em Pedagogia pela FFC-Unesp, campus de Marília (2009); mestre em Educação (2010) e doutor em Educação (2014) pela Unesp, campus de Marília. Realizou estágio de doutorado sanduíche no Instituto de Educação da Universidade de Lisboa. Representante regional (suplente) - Sudeste (2014-2016) da Associação Brasileira de Alfabetização (ABAlf).

Bárbara Cortella Pereira. Professora da Universidade do Estado de Mato Grosso (Unemat), campus de Tangará da Serra, e 
professora formadora do Pacto Nacional pela Alfabetização na Idade Certa/MEC-UFMT. É licenciada em Pedagogia (2006), mestre em Educação (2009) e doutora em Educação (2013) pela Unesp, campus de Marília. Realizou doutorado sanduíche na École des Hautes Études en Sciences Sociales (EHESS), Paris, França. Associada-fundadora da ABAlf.

Luzia de Fátima Paula. Professora da União das Escolas do Grupo Faimi, de Educação, na cidade de Mirassol (SP). Atua como coordenadora no curso de Pedagogia. É licenciada em Letras pela Unesp, campus de São José do Rio Preto (1999); é pedagoga pela União das Escolas do Grupo Faimi, de Educação (2003); mestre em Educação (2004) e doutora em Educação (2010) pela Unesp, campus de Marília.

Angélica Pall Oriani. Licenciada em Pedagogia com habilitação em Educação Infantil (2007) e em Administração Escolar para a Educação Básica (2008) pela FFC-Unesp-Marília; mestre em Educação (2010) e doutoranda em Educação pela Unesp, campus de Marília.

Franciele Ruiz Pasquim. Licenciada em Pedagogia (2010) pela FFC-Unesp, campus de Marília; mestre em Educação (2013) e doutoranda em Educação pela Unesp, campus de Marília.

Monalisa Renata Gazoli. Professora do Curso de Pedagogia do Plano Nacional de Formação de Professores da Educação Básica - Parfor presencial, introduzido pela Coordenação de Aperfeiçoamento de Pessoal de Nível Superior (Capes), em regime de colaboração com o Centro Universitário Católico Auxilium - Unisalesiano, Lins (SP). É licenciada em Pedagogia (2007) e mestre em Educação (2010) pela FFC-Unesp, campus de Marília. Associada-fundadora da ABAlf.

Cyntia Grizzo Messenberg. Professora das Faculdades Integradas de Botucatu e da Fundação Educacional "Dr. Raul Bauab". Atua no curso de especialização em Educação Especial como professora de Sociologia nos cursos de Administração e Ciências Contábeis e como professora de Matemática, História e 
Geografia do ensino fundamental - ciclo I. É licenciada em Pedagogia (2008) e mestre em Educação (2012) pela FFC-Unesp, campus de Marília. É especialista (2013) em Psicopedagogia pelas Faculdades Integradas da Fundação Educacional "Dr. Raul Bauab".

Luana Grazielle dos Santos. É licenciada em Pedagogia com habilitação em Administração Escolar para a Educação Básica pela FFC-Unesp, campus de Marília (2008) e especialista em Psicopedagogia pela Pontifícia Universidade Católica de São Paulo (2010).

Vanessa Cuba Bernardes. Professora da Rede Pública Municipal de São Paulo. Atua como professora de Educação Infantil e Ensino Fundamental I. Graduada em Pedagogia (2003) pela FFC-Unesp, campus de Marília. 
SOBRE O LIVRO

Formato: $14 \times 21 \mathrm{~cm}$

Mancha: 23,7 x 42,5 paicas

Tipologia: Horley Old Style 10,5/14

Papel: Off-set $75 \mathrm{~g} / \mathrm{m}^{2}$ (miolo)

Cartão Supremo $250 \mathrm{~g} / \mathrm{m}^{2}$ (capa)

1a edição: $201 \square$

EQUIPE DE REALIZAÇÃO

Coordenação Geral

Marcos Keith Takahashi 